\title{
Geohydrologic and Water-Quality Assessment of the Fort Leonard Wood Military Reservation, Missouri, 1994-95
}

By Jeffrey L. Imes, John G. Schumacher, and Michael J. Kleeschulte

U.S. GEOLOGICAL SURVEY

Water-Resources Investigations Report 96-4270

Prepared in cooperation with the

DIRECTORATE OF PUBLIC WORKS,

ENVIRONMENTAL DIVISION,

FORT LEONARD WOOD MILITARY RESERVATION

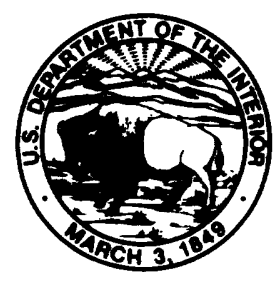




\title{
U.S. DEPARTMENT OF THE INTERIOR \\ BRUCE BABBITT, Secretary
}

\author{
U.S. GEOLOGICAL SURVEY \\ Gordon P. Eaton, Director
}

For additional information write to:

District Chief

U.S. Geological Survey

1400 Independence Road

Mail Stop 100

Rolla, MO 65401
Copies of this report may be purchased from:

U.S. Geological Survey

Branch of Information Services

Box 25286

Denver, CO 80225-0286 


\section{CONTENTS}

Abstract

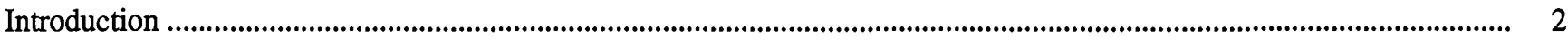

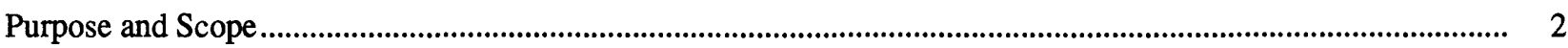

Fort Leonard Wood Military Reservation History and Facilities ................................................................................. 5

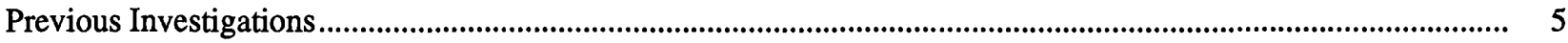

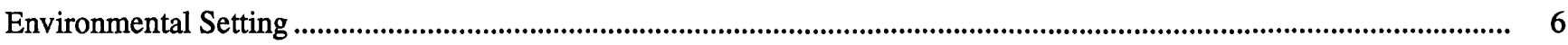

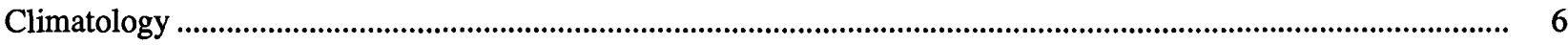

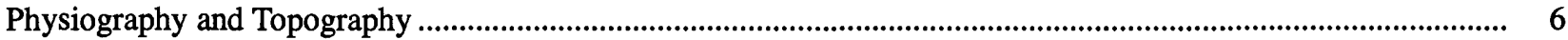

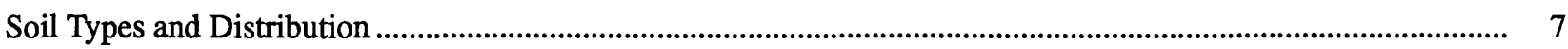

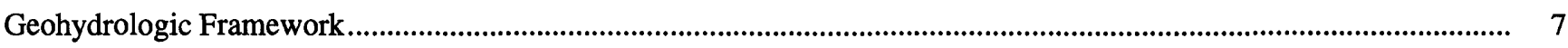

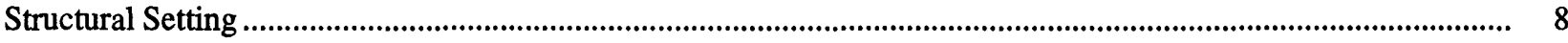

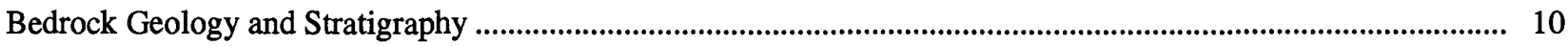

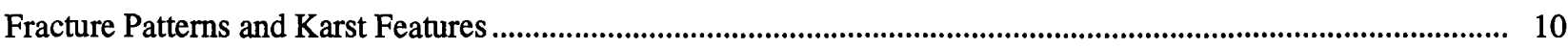

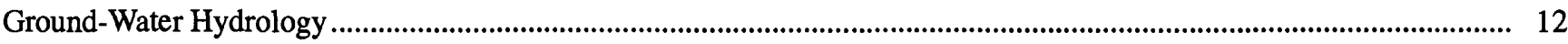

Ground-Water Levels_High-Base Flow ................................................................................................................ 13

Ground-Water Levels_Low-Base Flow ............................................................................................................. 18

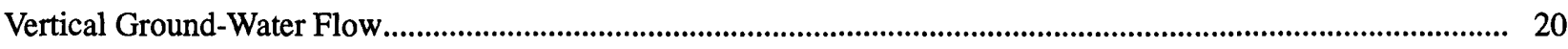

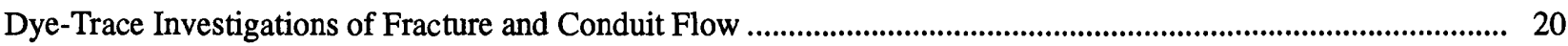

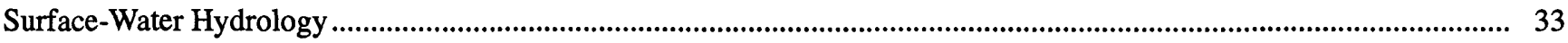

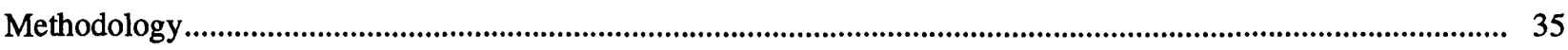

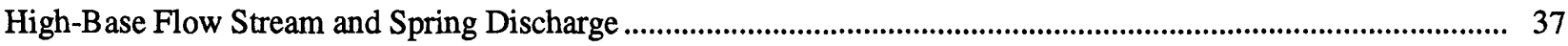

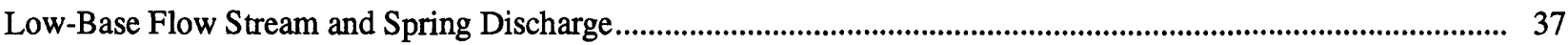

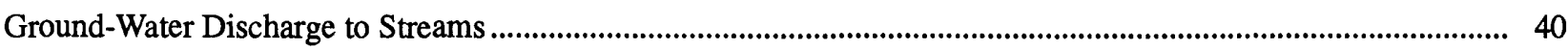

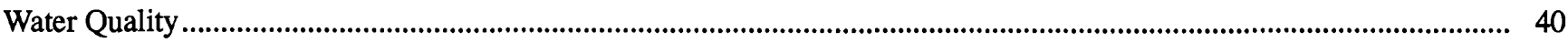

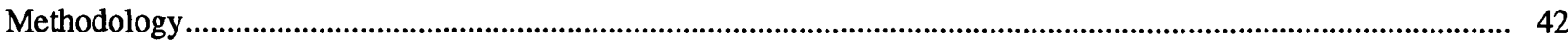

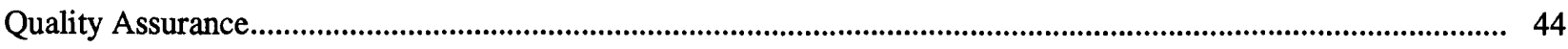

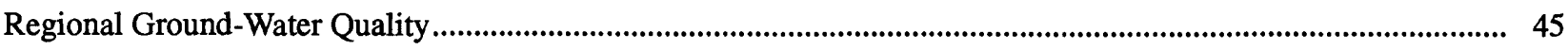

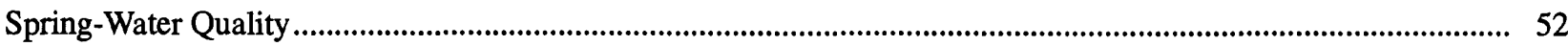

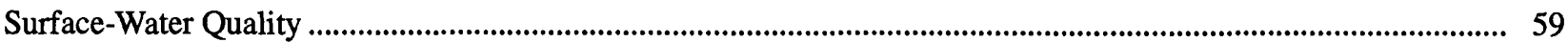

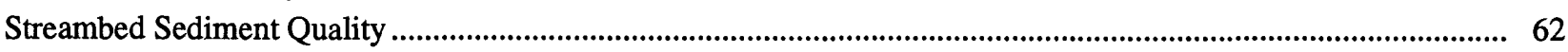

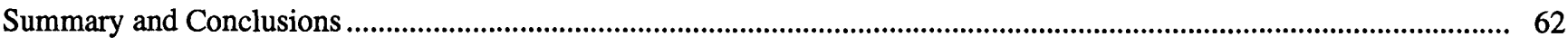

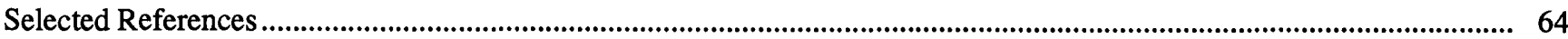

\section{FIGURES}

1-3. Maps showing:

1. Location of the Fort Leonard Wood Military Reservation and 17 solid-waste management units identified as potential sources of ground- or surface-water contamination .................................................. 3

2. Bedrock geologic formations at the Fort Leonard Wood Military Reservation............................................

3. Distribution of sinkholes and springs at and near the Fort Leonard Wood Military Reservation .................. 9 
4. Generalized geologic sections trending northwest to southeast across the Fort Leonard Wood Military

Reservation

5-8. Maps showing:

5. Altitude of shallow ground-water levels at and near the Fort Leonard Wood Military Reservation during high-base flow conditions

6. Altitude of shallow ground-water levels at and near the Fort Leonard Wood Military Reservation during low-base flow conditions

7. Injection and recovery points for dye-trace tests T103-01 to T103-07 and historical dye-trace tests at and near the Fort Leonard Wood Military Reservation

8. Distribution of charcoal packets placed in surface water and springs for monitoring of background dye concentrations at and near the Fort Leonard Wood Military Reservation

9-15. Graphs showing spectral analysis of fluorescent material extracted from activated charcoal packets placed in:

9. Shanghai Spring during dye-trace test $\mathrm{T} 103-01$

10. Miller Spring during dye-trace test T103-03

11. Miller Spring during dye-trace test T103-04

12. Shanghai Spring during dye-trace test T103-05

13. Roubidoux Spring during dye-trace test T103-06

14. The pumping station spring during dye-trace test $\mathrm{T} 103-07$

15. Shanghai Spring during dye-trace test T103-07

16-19. Maps showing:

16. Probable catchment areas of selected major springs at and near the Fort Leonard Wood Military Reservation

17. Stream discharge measurements for the high-base flow seepage run made on the Big Piney River,

Roubidoux Creek, and selected small tributary streams in December 1994 at and near the Fort Leonard Wood Military Reservation

18. Stream discharge measurements for the high-base flow seepage run made on the Big Piney River in February 1995 at and near the Fort Leonard Wood Military Reservation

19. Stream discharge measurements for low-base flow seepage run made on the Big Piney River, Roubidoux Creek, and selected small tributary streams in September 1995 at and near the

Fort Leonard Wood Military Reservation

20. Graphs showing variations in stream discharge (corrected for tributary and spring inflow and for daily flow rate variation) along the Big Piney River and Roubidoux Creek

21. Map showing location of domestic and public-supply wells sampled at and near the Fort Leonard Wood Military Reservation

22. Trilinear diagram depicting relative concentrations of major cations and anions in ground-water samples. 50

23. Graph showing sum of calcium, magnesium, and strontium as related to bicarbonate in water samples from wells and springs at the Fort Leonard Wood Military Reservation

24. Map showing location of spring, surface-water, or streambed sediment sample sites at the Big Piney River, Roubidoux Creek, and tributaries and contributing springs at and near the Fort Leonard Wood Military Reservation

25. Trilinear diagram depicting relative concentrations of major cations and anions in spring samples 54

26. Boxplots of selected physical properties and chemical constituents in water samples from wells, springs, and major streams and tributaries at the Fort Leonard Wood Military Reservation.

27. Trilinear diagram depicting relative concentrations of major cations and anions in surface-water samples 


\section{TABLES}

1. Water-level measurements made in selected domestic and public-supply wells during high-base and low-base flow conditions at and near the Fort Leonard Wood Military Reservation.

2. Summary for injection site and attempted recovery sites during dye-trace test T103-01 ................................. 71

3. Summary for successful dye recovery at Shanghai Spring during dye-trace test T103-01 ................................. 72

4. Summary for injection site and attempted recovery sites during dye-trace test T103-02 .................................... 73

5. Summary for injection site and attempted recovery sites during dye-trace test $\mathrm{T} 103-03$.................................... 74

6. Summary for successful dye recovery at Miller Spring during dye-trace test T103-03 ..................................... 75

7. Summary for injection site and attempted recovery sites during dye-trace test T103-04 .................................... 76

8. Summary for successful dye recovery at Miller Spring during dye-trace test T103-04........................................ 77

9. Summary for injection site and attempted recovery sites during dye-trace test T103-05 ...................................78

10. Summary for successful dye recovery at Shanghai Spring during dye-trace test T103-05 ................................ 79

11. Summary for injection site and attempted recovery sites during dye-trace test T103-06 .................................... 80

12. Summary for successful dye recovery at Roubidoux Spring during dye-trace test T103-06 ............................... 81

13. Summary for injection site and attempted recovery sites during dye-trace test T103-07 ................................... 82

14. Summary for successful dye recovery at the pumping station spring during dye-trace test T103-07.................... 83

15. Summary for uncertain dye recovery at Shanghai Spring during dye-trace test T103-07 .................................. 84

16. Discharge measurements and selected physical properties for the Big Piney River, Roubidoux Creek, and tributaries, December 1994

17. Discharge measurements and selected physical properties for the Big Piney River and tributaries, February 1995

18. Discharge measurements and selected physical properties for the Big Piney River, Roubidoux Creek, and tributaries, September 1995

19. Constituents and detection limits of inorganic and organic analyses for water and sediment samples and Missouri Department of Natural Resources drinking-water maximum contaminant levels (MCL).

20. Quality-assurance data for physical properties and inorganic constituents in duplicate and blank water samples

21. Physical properties and inorganic constituents in ground-water samples from wells at and near the Fort Leonard Wood Military Reservation

22. Physical properties and inorganic constituents in water samples from springs at and near the Fort Leonard Wood Military Reservation

23. Physical properties and inorganic constituents in surface-water samples collected at and near the Fort Leonard Wood Military Reservation

24. Concentrations of volatile organic compounds and pesticides detected in water samples at and near the Fort Leonard Wood Military Reservation

25. Background concentrations of selected physical properties and major and trace inorganic constituents in ground-water, spring, and surface-water samples at and near the Fort Leonard Wood Military

Reservation

26. Simulation of water quality at Shanghai Spring. 


\section{ACRONYMS AND INITIALISMS}

$\begin{array}{ll}\text { BTEX } & \text { Benzene-Toluene-Ethylbenzene-Xylene } \\ \text { CCD } & \text { Capitina-Clarksville-Doniphan } \\ \text { CFR } & \text { Code of Federal Regulations } \\ \text { DOD } & \text { U.S. Department of Defense } \\ \text { DPWED } & \text { Directorate of Public Works, Environmental Division } \\ \text { DRMO } & \text { Defense Reutilization Maintenance Office } \\ \text { FLW } & \text { Fort Leonard Wood } \\ \text { FLWMR } & \text { Fort Leonard Wood Military Reservation, also Base } \\ \text { FSP } & \text { Field Sampling Plan } \\ \text { GC-FID } & \text { Gas Chromatograph with Flame Ionization Detection } \\ \text { HACN } & \text { Hartville-Ashton-Cedargap-Nolin } \\ \text { IRP } & \text { Installation Restoration Program } \\ \text { MCL } & \text { Maximum Contaminant Level } \\ \text { MDGLS } & \text { Missouri Department of Natural Resources, Division of Geology and Land Survey } \\ \text { NCO } & \text { Non-Commissioned Officers } \\ \text { NVW } & \text { Needleye-Viraton-Wilderness } \\ \text { OB/OD } & \text { Open-Burn/Open-Detonation } \\ \text { OSHA } & \text { Occupational Safety and Health Act } \\ \text { PCB } & \text { Polychlorinated biphenyls } \\ \text { QA } & \text { Quality Assurance } \\ \text { QAPP } & \text { Quality-Assurance Project Plan } \\ \text { QC } & \text { Quality Control } \\ \text { RCRA } & \text { Resource Conservation and Recovery Act } \\ \text { SARA } & \text { Superfund Amendments and Reauthorization Act } \\ \text { STP } & \text { Sewage Treatment Plant } \\ \text { SWMU } & \text { Solid-waste management unit } \\ \text { USAEHA } & \text { U.S. Army Environmental Hygiene Agency } \\ \text { USAF } & \text { U.S. Air Force } \\ \text { USEPA } & \text { U.S. Environmental Protection Agency } \\ \text { USGS } & \text { U.S. Geological Survey } \\ \text { USMC } & \text { U.S. Marine Corps } \\ \text { VOC } & \text { Volatile organic compound } \\ \text { XAC } & \text { Explosives associated compound } \\ & \end{array}$

The use of trade, product, industry, or firm names in this report is for identification or location purposes only, and does not constitute endorsement of products by the U.S. Geological Survey, nor impute responsibility for any present or potential effects on the natural resources. 


\title{
Geohydrologic and Water-Quality Assessment of the Fort Leonard Wood Military Reservation, Missouri, 1994-95
}

\author{
By Jeffrey L. Imes, John G. Schumacher, and Michael J. Kleeschulte
}

\section{ABSTRACT}

A coordinated regional geohydrologic and water-quality assessment of the Fort Leonard Wood Military Reservation (FLWMR) in southcentral Missouri, has described geologic controls on ground-water flow at the FLWMR and provided a reliable data base of background groundand surface-water quality. Ground-water levels and flow directions beneath the FLWMR are similar under conditions of high-base and low-base flow and have been modified from pre-karst conditions in the central and northeastern parts of the FLWMR by substantial karst development. Fractures commonly do not extend through the full thickness of bedrock formations and display little evidence of solution activity. Substantial dissolution of interbedded dolomitic material in the Roubidoux Formation has caused collapse of overlying sandstone-rich strata and provided large permeability pathways for ground-water flow. The catchment areas for Shanghai Spring and Miller Spring, discharge points for large volumes of water infiltrating upland areas at the FLWMR, are better delineated by dye-trace investigations conducted during the study. Stream-discharge measurements indicate that water in the Big Piney River and lower Roubidoux Creek near the FLWMR is almost entirely derived from tributary and spring inflow. The upstream-most reach of Roubidoux Creek on the FLWMR receives substantial ground-water recharge through its streambed.
Results of ground-water sampling indicate that the shallow ground water is vulnerable to contamination from surficial sources. Samples from several wells indicated human or animal wastes effects or nitrogen-containing fertilizers and contained detectable concentrations of pesticides. Volatile organic compounds detected in small concentrations in ground water include probable by-products of well chlorination (chloromethane, trichloromethane, bromomethane, bromodichloromethane, dibromochloromethane, and bromoform), total xylenes, methyltertiarybutylether, and non-target volatile organic compounds tentatively identified as dibromomethylbenzene, 1-bromo-3,5-dimethylbenzene, 4-bromo-1,2-dimethylbenzene, cyanogen chloride, 2-methylpropanal, pentanal, and 2,4-dimethyl heptane. No semivolatile organic compounds or explosives associated compounds were detected, but the pesticides diazinon, $p, p^{\prime}-\mathrm{DDE}$, and tebuthiuron were detected.

Two springs, Shanghai Spring and the pumping station spring, show probable septic contamination. Ballard Hollow Spring shows fecal coliform and fecal streptococcus bacteria contamination that may originate at a nearby horse stable. Shanghai Spring contains detectable concentrations of the volatile organic compound trichloromethane (possibly a preservative contaminant) and the pesticides prometon and simazine. Substantial concentrations of the volatile organic compound tetrachloroethene (PCE) also were detected. No surface-water samples 
from streams exiting or bordering the FLWMR contained volatile or semivolatile organic compounds or explosives associated compounds. The pesticides tebuthiuron, atrazine, deethylatrazine, and $p, p^{\prime}$-DDE were detected in the Big Piney River and a tributary. Small concentrations of octachlorodibenzoparadioxin (OCDD), a natural combustion product, were detected in streambed sediment.

\section{INTRODUCTION}

During 1980, the U.S. Department of Defense (DOD) devised a comprehensive Installation Restoration Program (IRP) to assess and to control the migration of environmental contamination that may have resulted from past operations or disposal practices at DOD facilities. The IRP underwent changes after the Superfund Amendments and Reauthorization Act (SARA) was passed during 1986. This Act requires federal facilities to adhere to guidelines and procedures set forth by the U.S. Environmental Protection Agency (USEPA) for the investigation and restoration of former disposal and spill sites. The long-range objectives of the IRP at the FLWMR are to assess the extent and magnitude of contamination at selected closed solid-waste management units (SWMUs).

During 1994, the Directorate of Public Works, Environmental Division (DPWED), FLWMR requested support from the U.S. Geological Survey (USGS) in a regional basewide geohydrologic and water-quality assessment and investigation of the quality of water at selected SWMUs at the FLWMR (fig. 1). The regional geohydrologic assessment was designed to characterize the geohydrologic framework of the FLWMR and provide the background hydrochemical data necessary to conduct and interpret more detailed investigations of contaminant distribution and movement near individual SWMUs. Specific objectives for the regional assessment were:

1) to determine regional ground-water flow directions and discharge locations in and bordering the FLWMR, and

2) to assess the current and background groundand surface-water quality in and bordering the FLWMR.

The study area for the reconnaissance appraisal of the 17 selected SWMUs includes the immediate vicinity of each site and areas to which ground or sur- face water can readily migrate from the site. Preliminary site-specific investigations at 11 SWMUs (fig. 1) currently (1996) are completed on the FLWMR. Many leachate, ground- and surface-water, soil, and sediment samples have been collected from areas in and near these selected SWMUs. Investigations at six sites (FLW-006, FLW-012, FLW-013, FLW-014, FLW-015, and FLW-016) have been temporarily suspended and little data have been collected at these sites. The 17 sites selected for detailed study are:

$\begin{array}{ll}\text { FLW-002 } & \text { Closed sanitary landfill 2 } \\ \text { FLW-003 } & \text { Closed sanitary landfill 3A } \\ \text { FLW-004 } & \text { Closed sanitary landfill 3B } \\ \text { FLW-005 } & \text { Closed sanitary landfill 3C } \\ \text { FLW-006 } & \text { Closed sanitary landfill at ballfield } \\ \text { FLW-012 } & \text { Closed sanitary landfill 10A } \\ \text { FLW-013 } & \text { Closed sanitary landfill 10B } \\ \text { FLW-014 } & \text { Closed sanitary landfill 11A } \\ \text { FLW-015 } & \text { Closed sanitary landfill 11B } \\ \text { FLW-016 } & \text { Closed sanitary landfill 11C } \\ \text { FLW-028 } & \begin{array}{c}\text { Directorate of Public Works old } \\ \text { fire training area }\end{array} \\ \text { FLW-030 } & \begin{array}{c}\text { Open-burn/open-detonation } \\ \text { (OB/OD) area in range 24 }\end{array} \\ \text { FLW-032 } & \begin{array}{c}\text { Air National Guard cannon range } \\ \text { open-burning, explosives associated } \\ \text { compounds (XACs) burial area }\end{array} \\ \text { FLW-037 } & \begin{array}{c}\text { Directorate of Public Works old } \\ \text { pesticide storage building 2206 }\end{array} \\ \text { FLW-040 } & \begin{array}{c}\text { Ammunition container storage area } \\ \text { FLW-059 }\end{array} \\ \text { Closed sanitary landfill } \\ \text { FLW-060 } & \text { Closed sanitary landfill }\end{array}$

\section{Purpose and Scope}

This report presents the results of a coordinated geological, hydrological, and hydrochemical data-collection and data-analysis effort designed to characterize regional ground- and surface-water flow and quality at the FLWMR. The study was conducted from October 1994 to October 1995. The study area for geohydrologic assessment included the 64,000-acre FLWMR and bordering areas. The bordering areas of interest were areas east of the FLWMR between the military reservation and the Big Piney River, including the river (fig. 2); areas west of the FLWMR between the reservation and Roubidoux Creek, including the creek (fig. 2); and the small area north of the FLWMR between the Big Piney River and Roubidoux Creek, and south of Interstate 44 (figs. 1, 2). 

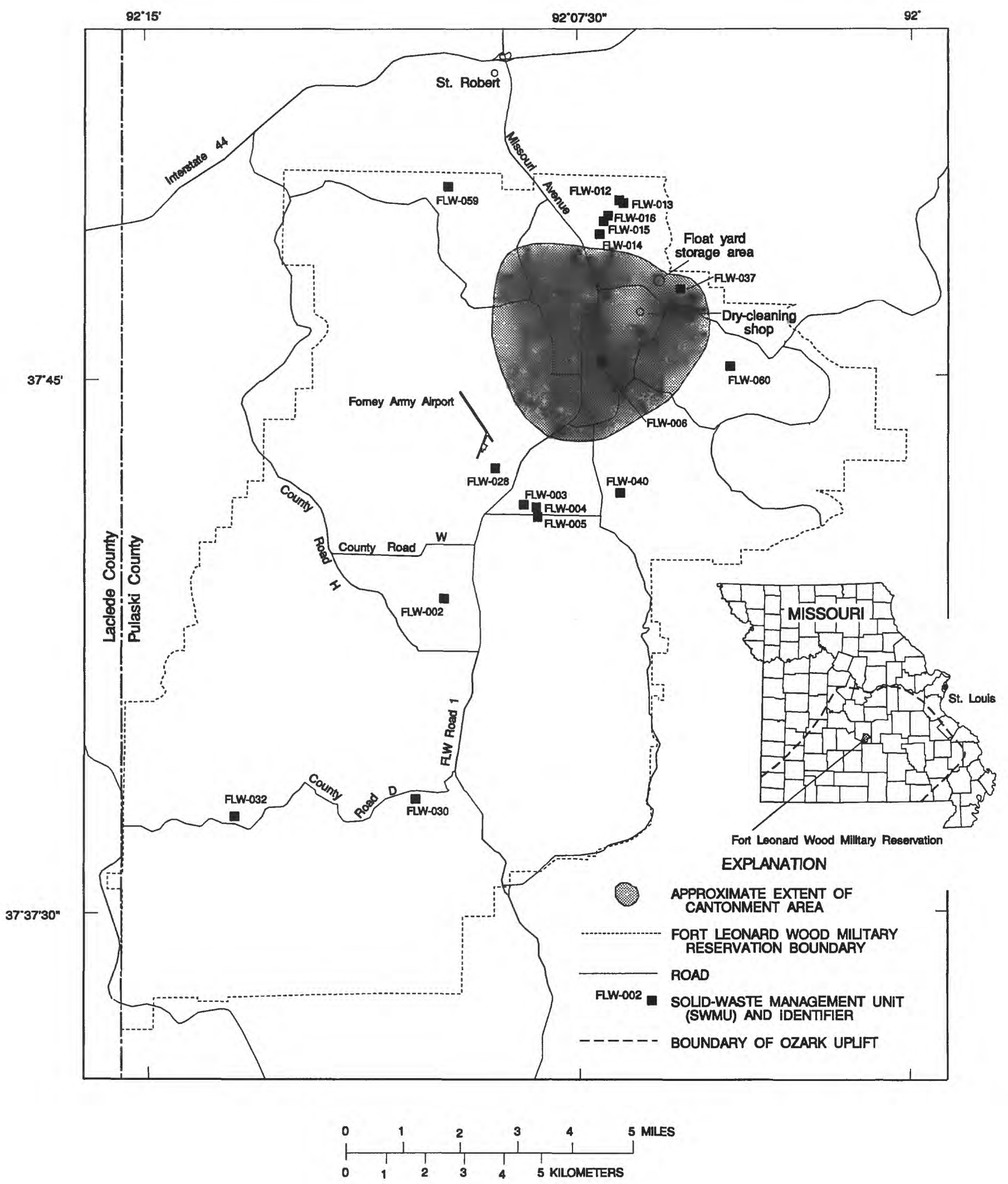

Figure 1. Location of the Fort Leonard Wood Military Reservation and 17 solid-waste management units identified as potential sources of ground- or surface-water contamination. 


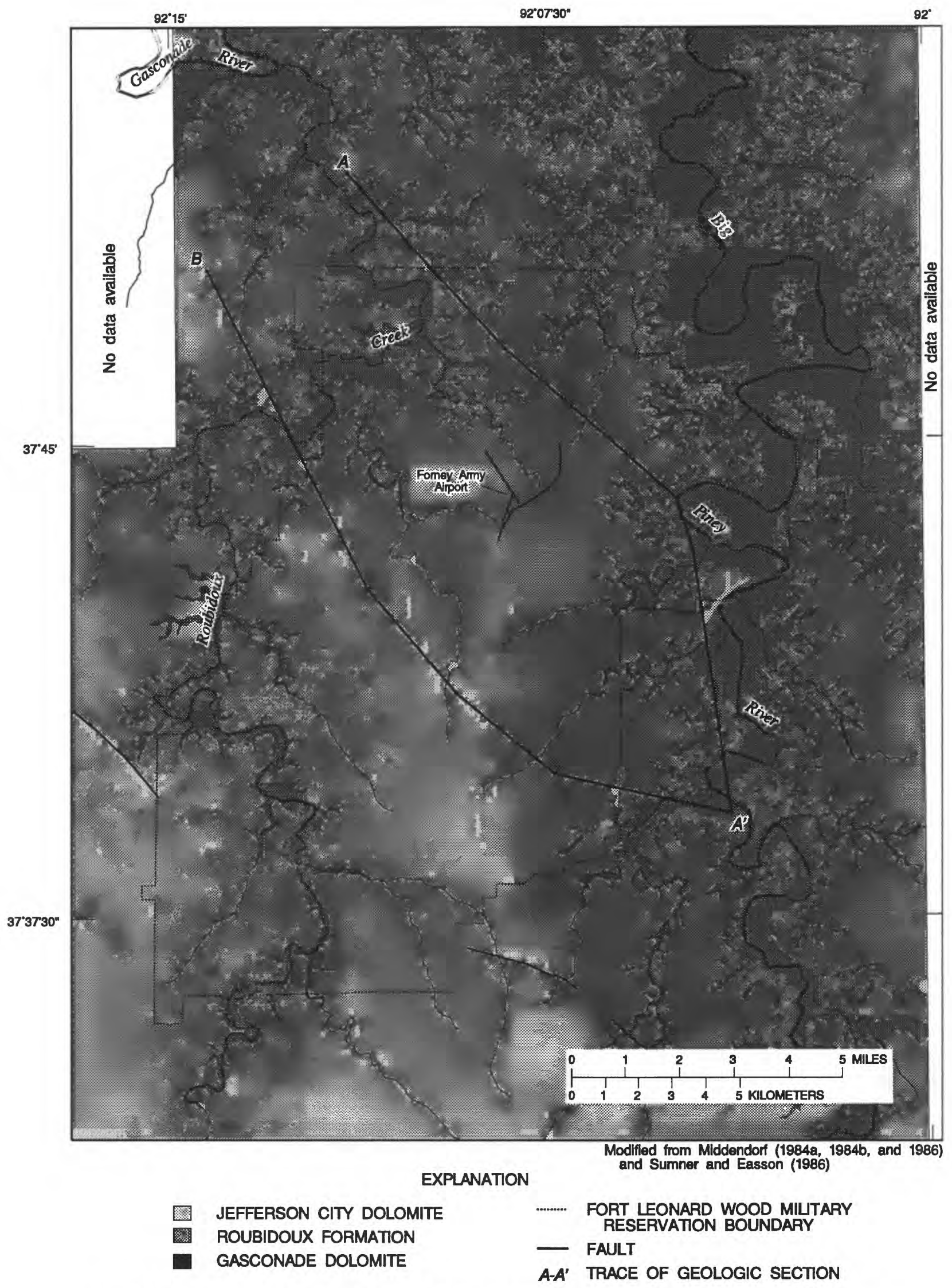

Figure 2. Bedrock geologic formations at the Fort Leonard Wood Military Reservation. 
Regional ground-water flow directions were determined by developing potentiometric surface maps based on ground-water-level measurements in domestic and public-water-supply wells. Groundwater discharge was measured directly at the many springs that flow from karstic limestone and dolostone bedrock at the FLWMR and indirectly by measuring changes in surface-water flow rates for the Big Piney River, Roubidoux Creek, and their tributaries that drain the FLWMR. Ground-water, surface-water, and streambed material samples were collected from various locations at the FLWMR to define the water quality and the relation to the water quality of the immediate surrounding area. Sampling locations generally were chosen to represent the regional water quality at the FLWMR, rather than chosen to be representative of any specific area. Most of the sample sites characterize native or natural water quality. Site specific data for the SWMUs are not included in this regional geohydrologic report.

\section{Fort Leonard Wood Military Reservation History and Facilities}

The FLWMR is located in south-central Missouri (fig. 1), approximately $130 \mathrm{mi}$ (miles) southwest of the city of St. Louis. The mission of the FLWMR primarily is combat troop training. It consists of approximately 64,000 acres of land, including a small aircraft landing strip, Forney Army Airport. The history of the FLWMR began during 1941 when it was opened for the training of combat troops in World War II. The FLWMR was closed during 1946 at the end of the war, but was re-opened in 1956 as a combat troop training center and engineering school.

Many facilities are concentrated in the cantonment area (fig. 1) that occupies the north-central part of the FLWMR. This area contains classrooms, barracks, recreation and shopping facilities, and support units. The remainder of the FLWMR contains large tracts of land set aside for small arms firing ranges, training areas for armored vehicles night maneuvers, an Air National Guard cannon and strafing range, and heavy equipment training areas. Currently (1996), the FLWMR is home to the 1st Engineer Brigade (Center), the 3rd Basic Training Brigade, the 43rd Adjutant General Battalion, and a Military Police Command.

The 1st Engineer Brigade (Center) provides support for Engineer Officer Basic and Engineer Officer Advanced Training Courses and includes an engineer combat battalion composed of two fire-fighting detachments, an evacuation hospital, a transportation company, an engineer pipeline company, an engineer company, and a quarry company. The 3 rd Basic Training Brigade annually trains 20,000 initialentry recruits and 4,000 combat engineers and provides support services for several Army Reserve Units. The 43rd Adjutant General Battalion supplies inprocessing services, training of Non-Commissioned Officers (NCO) through the Libby Non-Commissioned Officer Academy, basic NCO courses, advanced NCO courses, Drill Sergeant School, and Initial Entry Cadre Training.

Several tenant organizations operate on the FLWMR, including the Medical Department, which operates the General Leonard Wood Army Hospital, Dental Activity, Defense Printing Service, Testing and Evaluation Coordination Office, Defense Investment Service, Ordnance Disposal Detachment, Army Trial Defense Service, Resident Agency, U.S. Marine Corps (USMC) Administration Detachment, U.S. Air Force (USAF) Technical Training Group, U.S. Army Defense Reutilization Maintenance Office (DRMO), Commissary, Army Reserve Training Center, Army Readiness Group, Tactical Fighter Wing Detachment 1 of the Air National Guard, Engineer Housing Support Center, and Army Information Center.

\section{Previous Investigations}

Previous hydrologic investigations at the FLWMR have focused almost exclusively on chemical analyses of ground-water samples collected from monitoring wells installed near selected SWMUs. None of these studies have attempted to understand the regional ground-water and surface-water hydrology of the FLWMR or the geohydrologic settings of the SWMUs in relation to the regional hydrology.

During 1987 and 1988, the U.S. Army Environmental Hygiene Agency (USAEHA, 1988a) conducted an investigation of the effect of SWMUs FLW002, FLW-003, FLW-004, and FLW-005 on ground water in nearby unconsolidated deposits. Seventeen shallow wells were drilled into the unconsolidated deposits to collect ground-water samples. Depth to the water table in the upland area commonly exceeds 100 $\mathrm{ft}$ (feet), which accounts for the observation that all 17 wells were dry in the fall and only 3 contained sufficient water to sample in the spring. The sampled water probably was water temporarily perched above less 
permeable sediments. One landfill leachate sample was collected. The report concludes that there was no adverse effects on ground-water in the unconsolidated deposits; however, two of four samples had concentrations of sodium [ 28 to $102 \mathrm{mg} / \mathrm{L}$ (milligrams per liter)] and chloride ( 37 and $97 \mathrm{mg} / \mathrm{L}$ ) larger than expected background concentrations, indicating effects from landfill leachate.

A later study conducted by the USAEHA (1988b) documented and characterized 40 SWMU sites and concluded that sites FLW-002, FLW-003, FLW-004, FLW-005, FLW-022, FLW-028, FLW-030, FLW-032, and FLW-037 warranted additional environmental investigations. No monitoring-well drilling or water sampling was conducted during this study.

Three additional deeper monitoring wells ranging from 83 to $100 \mathrm{ft}$ deep were installed around the perimeter of FLW-002 in 1990. Water levels in these wells ranged from 33 to $69 \mathrm{ft}$ below land surface. No organic compounds were detected in water samples from these wells. Four additional deeper monitoring wells also were installed during 1990 around landfill FLW-003 and adjacent landfills FLW-004 and FLW005 at depths of 57 to $103 \mathrm{ft}$. Only one well contained water and was sampled for trace elements, priority pollutant volatile organic compounds (VOCs), semivolatile organic compounds, pesticides, and polychlorinated biphenyls (PCBs). Organic compounds were not detected, but barium was detected at a concentration of $210 \mu \mathrm{g} / \mathrm{L}$ (micrograms per liter; U.S. Army Environmental Hygiene Agency, 1990).

During 1993, the USAEHA (1993) collected soil samples to characterize old fire training areas FLW-050, FLW-051, and FLW-052. Total petroleum hydrocarbon concentrations in 7 of 35 samples from FLW-050, 1 of 28 samples from FLW-051, and 1 of 15 samples from FLW-052 equaled or exceeded minimum detection limits of $4 \mu \mathrm{g} / \mathrm{L}$. No sample contained benzene, toluene, ethylbenzene, or xylene (BTEX) in concentrations greater than $1 \mu \mathrm{g} / \mathrm{L}$.

During 1993, the Radian Corporation (1993) completed a study of the float yard storage area, furniture repair shop satellite storage area, building 2563 battery acid storage area, and an open-burn/open-detonation (OB/OD) area in Cannon Range 36. Small concentrations of lead $(\mathrm{Pb})$ were detected in soils, and odors from soil sample boreholes indicated the presence of VOCs at the float yard storage area. Surface soil samples at the furniture repair shop area contained $\mathrm{Pb}$ concentrations of $156 \mathrm{mg} / \mathrm{kg}$ (milligrams per kilo- gram), but it was unclear whether this concentration was significant as compared to natural background $\mathrm{Pb}$ concentrations in the residuum (Connor and Shacklette, 1975), which can be as large as $120 \mathrm{mg} / \mathrm{kg}$. Volatile organic compounds also were detected in soils near the repair shop. Several XACs were detected in soil samples from the OB/OD area at Cannon Range 36. No evidence existed that the XACs were migrating offsite by overland runoff or had entered the groundwater system.

\section{ENVIRONMENTAL SETTING}

\section{Climatology}

The FLWMR area is characterized by a humid, temperate climate with warm, humid summers and cool, wet winters. The average annual temperature is $57^{\circ} \mathrm{F}$ (degrees Fahrenheit). The recorded temperature extremes at the Forney Army Airport from 1963 to 1994 are a maximum of $109^{\circ} \mathrm{F}$ (August 1980) and a minimum of $-13^{\circ} \mathrm{F}$ (December 1985). The average annual precipitation recorded at the airport is about 42 in. (inches; National Oceanic and Atmospheric Administration, 1951-80, 1994).

\section{Physiography and Topography}

The FLWMR occupies a large part of southern Pulaski County and a small part of eastern Laclede County in south-central Missouri. It is located within the Salem Plateau of the Ozark Plateaus Physiographic Province (Fenneman, 1938), an area characterized by a rugged terrain of thin soils and narrow steep-walled valleys. Most of the FLWMR is located on a broad ridge between the northerly flowing Big Piney River to the east and the northerly flowing Roubidoux Creek to the west (fig. 2). Tributary streams to the Big Piney River and Roubidoux Creek drain the upland areas and are deeply incised into the sides of the ridge.

Area relief generally is the result of gradual uplift of the Ozark Dome in southern Missouri and erosion of the uplifted rocks by precipitation runoff and streamflow. The regional land surface altitude ranges from about $1,150 \mathrm{ft}$ above sea level along parts of the central ridge to about $750 \mathrm{ft}$ above sea level at the Big Piney River near the northeastern boundary of the FLWMR. Roubidoux Creek is not as deeply 
incised, nor does it have as large a flow, as the Big Piney River. The altitude of Roubidoux Creek near the northwestern boundary of the FLWMR is about $780 \mathrm{ft}$ above sea level.

\section{Soil Types and Distribution}

The U.S. Department of Agriculture, Soil Conservation Service (1979) has surveyed and mapped soils at the FLWMR. Surface soils at the FLWMR generally were formed over consolidated sandstone and cherty limestone bedrock deposits. Three general types of soils cover the FLWMR: the Needleye-Viraton-Wilderness (NVW), the Capitina-ClarksvilleDoniphan (CCD), and the Hartville-Ashton-CedargapNolin (HACN). The fragipan clay subsoils and soils, which are common to the area, contain a large clay content and can inhibit the downward movement of ground water in the unsaturated zone. Fragipan subsoils can locally alter the normal vertical movement of recharging ground water, causing the water to perch on top of the fragipan and flow laterally to more permeable vertical pathways or emerge at land surface as ground-water seeps.

The NVW soils, loamy upland soils with fragipans, commonly are along the nearly level to moderately steep central ridge of the FLWMR. These soils form in cherty limestone residuum and are characterized by a cherty silt loam surface soil overlying a moderately permeable cherty silty clay loam subsoil that is supported by an underlying massive compact brittle fragipan. The CCD soils are loamy upland soils that contain fragipan or are chert throughout. They commonly are on nearly level to extremely steep slopes between the central ridge of the FLWMR and the Big Piney River and Roubidoux Creek valleys. These soils form in cherty limestone and dolostone residuum and are characterized by a cherty silt loam surface soil overlying a massive compact brittle fragipan or moderately permeable clay subsoil. The HACN soils are poorly to excessively drained loamy bottom land soils commonly in the narrow Big Piney River and Roubidoux Creek valleys. These soils form in cherty limestone residuum and are characterized by a silt loam or cherty silt loam surface soil overlying a slowly to moderately permeable silt, silty clay, or cherty silt loam subsoil.

Most natural soils on the FLWMR have been altered extensively by construction and development on the FLWMR and ongoing training activities. In some large areas along the western flank of the central ridge, the surface soils and subsoils have been completely stripped or altered by years of heavy equipment training activities.

\section{GEOHYDROLOGIC FRAMEWORK}

The geohydrologic assessment of the FLWMR included a comprehensive geologic mapping program to identify fractures and faults and a less intensive effort to verify and refine existing bedrock geology maps. Onsite mapping was conducted by the USGS between November 1994 and May 1995. All onsite observations, data interpretations, and geologic mapping (compiled at 1:24,000 scale) are published separately from this report in Harrison and others (1996). The total mapped area was the approximate equivalent of three 7.5-minute quadrangle maps and generally extended from Interstate 44 to the southern boundary of the FLWMR and from Roubidoux Creek to the Big Piney River, including all parts of the FLWMR that are located outside of this general boundary. However, the geologic mapping program was centered on the FLWMR property and extended beyond the FLWMR property only to the extent necessary to support the mapping effort on the FLWMR property. Geologic descriptions in this report generally are condensed from the geologic mapping program and selected previous investigations. The reader is referred to Harrison and others (1996) for a more complete assessment of the geology of the FLWMR and a comprehensive set of observations made during the geologic mapping program.

Bedrock geologic formation maps (fig. 2) at the FLWMR were completed by the Missouri Department of Natural Resources, Division of Geology and Land Survey (MDGLS) in the mid 1980's. Bedrock geology maps of the southern two-thirds of the FLWMR were compiled at 1:62,500 scale (Middendorf, 1986; Sumner and Easson, 1986), and maps of the northern onethird were compiled at 1:24,000 scale (Middendorf, $1984 a, 1984 b)$. Because the focus of this study was on hydrology, not geology, no earnest attempt was made to refine these bedrock geology maps. However, as surficial expressions of bedrock contacts were observed onsite during fracture and fault mapping, the contacts were noted, and a revised bedrock geology map (Harrison and others, 1996) at 1:24,000 scale was produced that incorporated corrections and additions to the existing maps. 
Mapping of fractures included identification and characterization of fracture sets and characterization of fractures by persistence, aperture, and solution activity (hydrologically active or inactive). At the beginning of the study a substantial component of ground-water flow at the FLWMR was assumed to be controlled by permeable zones associated with solution-enlarged fractures and bedding planes. Thus, a large part of the geologic assessment was directed toward developing a better understanding of these geologic features.

\section{Structural Setting}

A preliminary assessment of the geologic structural setting of the FLWMR was conducted before onsite observations were initiated to determine the general relation between structural features beneath the FLWMR and the regional structure of the Ozark Uplift of southern Missouri (fig. 1). This assessment was accomplished by review of previously published maps and articles on the geology of southern Missouri and by preparation of structure maps of the base of the Roubidoux Formation and base of the Gasconade Dolomite near the FLWMR. The data base of the altitudes for geologic formation contacts used to construct these maps was compiled from data on file at the MDGLS.

The Ozark Uplift of southern Missouri is part of a large rhyolite-granite basement complex that probably formed a continental divide in Late Precambrian time (Lidiak and others, 1966; Muehlberger and others, 1966, 1967). Through a series of depositional and erosional cycles extending from Cambrian to Pennsylvanian time, the oldest geologic formations in southern Missouri crop out in southeastern Missouri, and younger formations crop out in approximately concentric rings around the older core. Rocks of early Ordovician age are exposed at the FLWMR, which is located on the northern flank of a structural high extending from southeast Missouri to the southwestern corner of the State (McCracken, 1971). The most prominent regional structural feature at the FLWMR is an unnamed anticline expressed as a north-trending ridge in contoured altitudes of the top of the Roubidoux Formation (McCracken, 1971, plate 1).

Maps of regional structure features and contours on the base of the Gasconade Dolomite and base of the Roubidoux Formation were prepared during the geologic assessment of the FLWMR. The base of the Gas- conade Dolomite (Harrison and others, 1996) is characterized by a low-altitude area in the central FLWMR area and an anticlinal ridge (maximum altitude about $750 \mathrm{ft}$ above sea level) extending northward through the northeastern and eastern part of the FLWMR. The low-altitude area is mapped based on only a single measurement and may be anomalous. The southern FLWMR area contains a prominent northwest-southeast trending normal fault, interpreted to be a segment of a single regional fault, previously mapped as the Countyline Fault to the northwest and the Palace Fault to the southeast (fig. 3). The fault has a displacement in excess of $100 \mathrm{ft}$ in some places. The Gasconade Dolomite is about $300 \mathrm{ft}$ thick at the FLWMR.

The structure of the base of the Roubidoux Formation (Harrison and others, 1996) is quite similar to that of the underlying Gasconade Dolomite. With the addition of more available data for the shallower Roubidoux Formation, the isolated low-altitude area in central FLWMR appears as part of a narrow elongated basin extending northeast from the Countyline Fault. The southwestern boundary of the basin is the downthrown side of Countyline Fault. The prominent north-trending anticlinal ridge is evident at the base of the Roubidoux Formation and attains a maximum altitude of about $1,050 \mathrm{ft}$ above sea level in the northern part of FLWMR. The thickness of the Roubidoux Formation is about $150 \mathrm{ft}$ at the FLWMR.

One of several interesting observations noted during the onsite mapping was structural evidence for substantial dissolution of the more dolomitic parts of the Roubidoux Formation (Harrison and others, 1996). Bedding plane attitudes in the underlying Gasconade Dolomite are nearly horizontal throughout the FLWMR. Bedding plane attitudes in sandstone beds of the upper part of the Roubidoux Formation consistently reflect a pattern of narrow steep-sided folds. The large difference in attitudes as measured in the two formations is regarded as a result of the dissolution of dolomitic material in the lower part of the Roubidoux Formation and subsequent collapse of the overlying sandstone-rich beds. The nature of the collapse indicates that solution activity in the Roubidoux Formation is concentrated in interbedded dolostone in the lower part of the formation. 


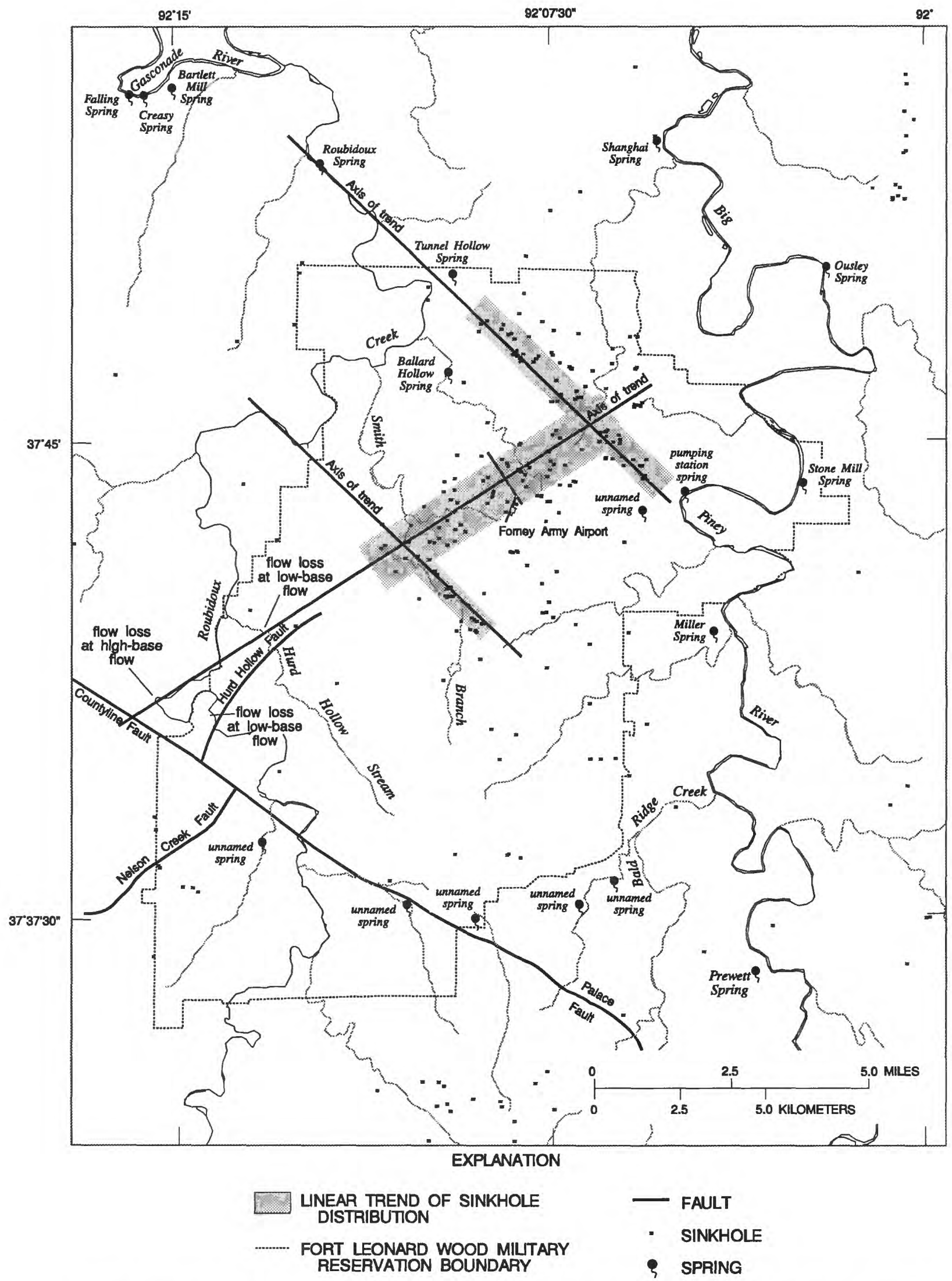

Figure 3. Distribution of sinkholes and springs at and near the Fort Leonard Wood Military Reservation. 


\section{Bedrock Geology and Stratigraphy}

Bedrock geology of the FLWMR area consists of a sequence of three lower formations of Ordovician age of the Canadian Series. The Gasconade Dolomite, predominantly a cherty dolostone, is the oldest bedrock formation that crops out at the FLWMR. Exposures of Gasconade Dolomite (fig. 2) primarily are seen as bedrock bluffs along the Big Piney River and Roubidoux Creek valleys. The approximately $250-\mathrm{ft}-$ thick lower part of the Gasconade Dolomite contains a sandstone unit, the Gunter Sandstone Member, that is persistent throughout most of southern Missouri, but is not exposed in the study area. The approximately 50ft-thick upper dolomitic section of the formation grades from a coarsely crystalline dolostone with a large chert content to an overlying more finely crystalline dolostone with a small chert content. The upper part of the Gasconade Dolomite was observed to contain intraformational breccia horizons as much as $4 \mathrm{ft}$ thick that probably are indicative of larger permeability zones and may be capable of rapidly transmitting large quantities of ground water. Most caves and larger springs in the study area are contained in the upper part of the Gasconade Dolomite.

The lithology of the overlying Roubidoux Formation ranges from sandstone to dolomitic sandstone and cherty dolostone. The Roubidoux Formation crops out (fig. 2) in upland areas and hillsides in the western, northern, and eastern parts of the FLWMR. Most of the observed sinkholes in the upland areas of FLWMR are formed in the Roubidoux Formation.

The youngest bedrock formation, the Jefferson City Dolomite, has a maximum thickness in the study area of about $200 \mathrm{ft}$ and is exposed in the southern part of the FLWMR along the central upland ridge that trends north-south through the FLWMR midway between the Big Piney River and Roubidoux Creek (fig. 2). This finely crystalline argillaceous dolostone commonly contains shale partings and brecciated chert. Solution activity was not observed in any Jefferson City Dolomite outcrop. Small ground-water seeps are common near the base of the dolostone and probably are caused by the resistant basal Quarry Ledge 1 . The beginning of flow in the headwaters of some small streams may be associated with the contact between

\footnotetext{
${ }^{1}$ Terminology is that of the Missouri Division of Geology and Land Survey.
}

the Roubidoux Formation and Jefferson City Dolomite.

Two geologic sections that trend northwestsoutheast across the central and northern parts of the FLWMR (fig. 4) show substantial stream entrenchment resulting from erosion of the Gasconade Dolomite and younger rocks by the Big Piney River and Roubidoux Creek. Beneath the Gasconade Dolomite, but not exposed in the FLWMR area, are the Eminence and Potosi Dolomites, Derby-Doe Run Dolomite, Davis Formation, Bonneterre Formation, and Lamotte Sandstone, all overlying Precambrian basement rocks. Most recharge at FLWMR probably does not flow into these deeper formations. The Potosi Dolomite is a massive thick-bedded dolostone that is vuggy and contains quartz druse. This formation is a source of ground water for municipalities throughout southern Missouri, and several public-supply wells in the FLWMR area are completed in the formation. The Potosi Dolomite is separated from the Gasconade Dolomite by the Eminence Dolomite, which commonly is less karstic and, therefore, less permeable than either the Potosi Dolomite or Gasconade Dolomite.

Modern stream valleys at and near the FLWMR, primarily the Big Piney River and Roubidoux Creek, contain thin alluvial deposits. This alluvium consists of both sorted and unsorted accumulations of sand, silt, gravel, and clay.

\section{Fracture Patterns and Karst Features}

The permeability of limestone and dolostone bedrock geologic formations that underlie the FLWMR has been greatly increased by dissolution. Evidence of the magnitude of dissolution is shown by the numerous, irregular, small folds with steep attitudes and the numerous sinkholes that have been created in the Roubidoux Formation by collapse of overburden into solution-enlarged cavities. Preliminary concepts of ground-water flow at the FLWMR assumed that solution-enlarged fracture systems were responsible for the observed patterns of sinkhole development and that conduit systems created from solution-enlarged intersecting fractures directed ground water to major springs. Therefore, the main emphasis of the geologic mapping program was to determine the density and properties of fractures in the FLWMR area. Specific physical properties measured during onsite observations included fracture orienta- 

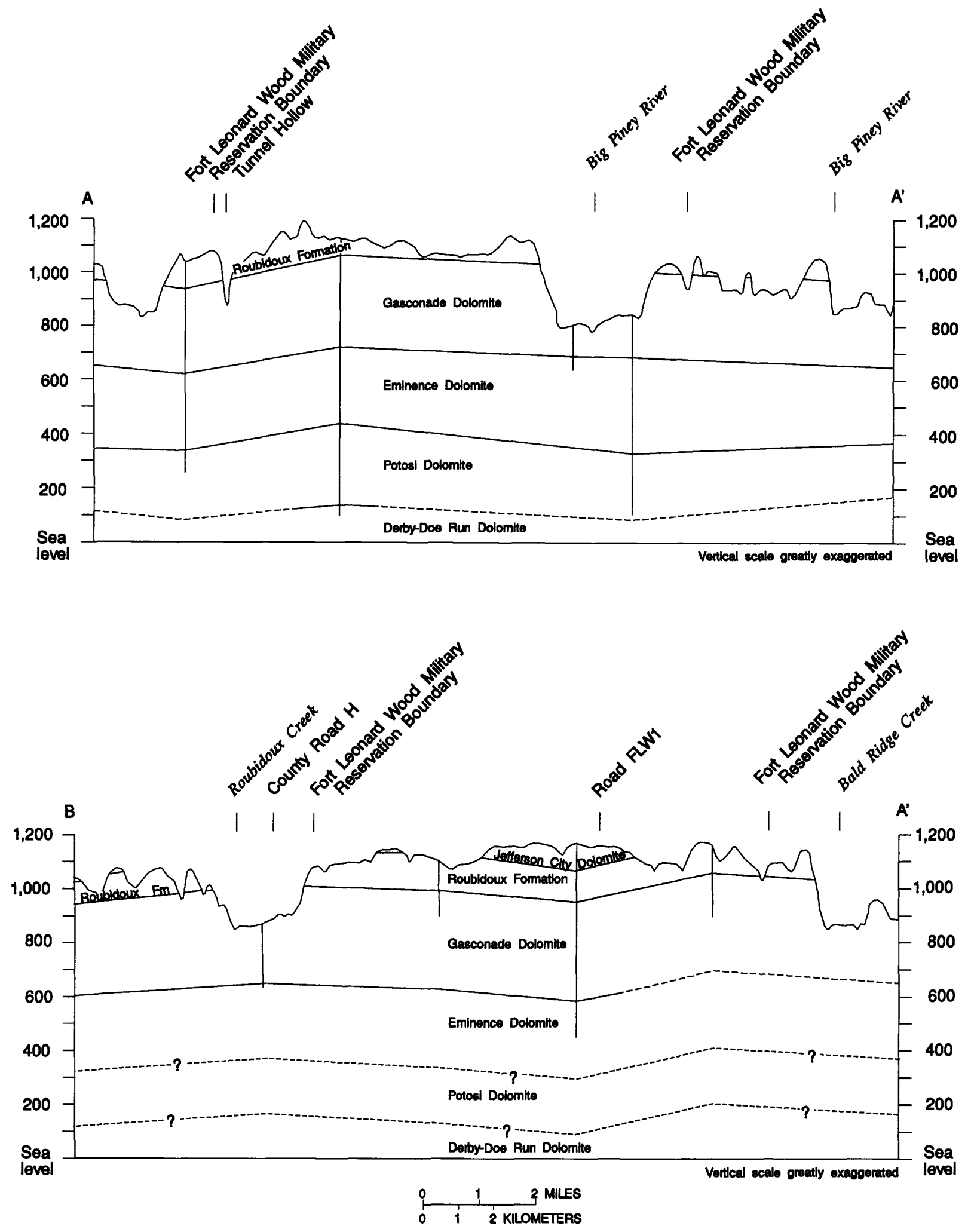

Figure 4. Generalized geologic sections trending northwest to southeast across the Fort Leonard Wood Military Reservation (the traces of sections $A-A^{\prime}$ and $B-A^{\prime}$ are shown in figure 2). 
tion and persistence and a characterization of fractures as hydraulically active or inactive based on evidence of solution activity in the fracture.

Before this study, fracture flow was thought to be the method by which recharge in upland areas of the FLWMR was transported rapidly through the Jefferson City Dolomite and Roubidoux Formation to the larger springs that flow from openings in the upper part of the Gasconade Dolomite. Onsite observations of hundreds of fractures at the FLWMR (Harrison and others, 1996) revealed that less than 10 percent of fractures in the Jefferson City Dolomite and less than 5 percent of fractures in the Roubidoux Formation extend through the entire thickness of the formations (through-going). About 10 percent of fractures in the Gasconade Dolomite are through-going. A larger density of through-going fractures are located near Roubidoux Creek and Smith Branch in the northwestern part of FLWMR where stream channels seem to be strongly controlled by fractures. Bedrock-formation fracture patterns display preferred orientations locally (fracture domains), but apparently neither throughgoing nor non-through-going fractures in the FLWMR area display a strong preferred regional orientation.

Of all observed fractures, only about 4.5 percent in the Jefferson City Dolomite, about 1.5 percent in the Roubidoux Formation, and about 20 percent in the Gasconade Dolomite show evidence of solution activity (Harrison and others, 1996). Fracture sets exhibiting solution activity have a pronounced northeast orientation. Conduit flow may have developed in some of these fractures. However, about 98 percent of all observed fractures have narrow (less than 0.5 in.) apertures and show no evidence of secondary mineralization. These observations, combined with evidence of extensive dissolution of interbedded dolostone in the lower part of the Roubidoux Formation and the fact that nearly 45 percent of all observed Gasconade Dolomite outcrops showed evidence of beddingplane-controlled caves, solution cavities, or vugs, lead to the conclusion that much of the water discharged at large springs is transported along high-permeability pathways within solution-enlarged bedding planes rather than fractures.

An inventory of typical karst features such as springs, seeps, losing streams, sinkholes, and caves was conducted during the regional geohydrologic assessment to help develop a more complete concept of ground-water flow. One observation, resulting from the compilation of sinkhole location data from USGS 7.5-minute topographic maps, high-resolution digital contour data for the FLWMR, and onsite observations, is that many of the sinkholes located in the north-central part of the FLWMR are distributed along a 1-miwide linear trend oriented northeast to southwest (fig. 3 ). The major axis of this band of sinkholes is parallel to and in line with a 1.5-mi-long linear segment of Roubidoux Creek within a reach of the creek characterized by a sequence of near right-angle shifts in flow direction and complete flow loss. The axis also intersects Hurd Hollow Stream at the point of flow loss. The occurrence of abrupt changes in stream channel directions, a linear stream segment, flow loss in two streams, and a linear band of sinkholes oriented along a common line strongly indicates an area of substantial hydrologic control by fractures.

The mapping of fractures resulted in the identification of previously unmapped faults that presumably are the cause of the lost surface-water flow in Roubidoux Creek and Hurd Hollow Stream. The faults are the previously mentioned extension of Countyline Fault into the southern FLWMR and Hurd Hollow Fault, which intersects the Countyline Fault at a steep angle in the vicinity of flow loss at low-base flow in Roubidoux Creek. The Hurd Hollow Fault extends northeast from the Countyline Fault into the interior of the FLWMR and crosses Hurd Hollow near the point of flow loss in Hurd Hollow Stream (Harrison and others, 1996; fig. 3). The mapping also identified the intersection of two smaller faults, a probable extension of Nelson Creek Fault and Hurd Hollow Fault, with the larger Countyline Fault.

Two narrower bands of sinkholes with major axes oriented northwest to southeast also are evident in figure 3. Extensions of the major axes of these bands also intersect near-linear segments of Roubidoux Creek northwest of the FLWMR. One of the bands also extends along a near-linear 1-mi-long reach of Smith Branch. These features also are indicative of fracture or fault control, but no direct evidence has been found that links these features to a common structure.

\section{GROUND-WATER HYDROLOGY}

Ground-water resources of the region primarily are associated with the Ozark Plateaus aquifer system, consisting of consolidated sediments of Cambrian through Ordovician age (Imes and Emmett, 1994). Ground-water supplies near the FLWMR are from 
wells that are completed in the Ozark aquifer, the middle aquifer of the Ozark Plateaus aquifer system. Although the lower few tens of feet of the Jefferson City Dolomite can be saturated locally at the FLWMR, the formation normally is unsaturated. The underlying Roubidoux Formation, Gasconade Dolomite, and Potosi Dolomite commonly are productive water-bearing formations. The upper part of the Eminence Dolomite commonly is a massive dolostone containing few vugs or solution features and probably forms a weak hydraulic barrier to vertical ground-water flow between the Gasconade Dolomite and Potosi Dolomite.

Recharge to the aquifer primarily is by percolation of precipitation through permeable residuum and bedrock. Ground-water flow in the aquifer mainly is controlled by regional topography, but local anomalies on the regional flow system are produced by flow through solution-enlarged openings in the karst bedrock. Karst features commonly are well developed in the Gasconade Dolomite and Potosi Dolomite. The presence of karst features can substantially alter the movement of ground water from flow patterns commonly associated with rocks of more uniform permeability. Because of the areal extent and the permeability of the aquifer, water-supply wells are numerous and productive. Wells completed in the Roubidoux Formation-Gasconade Dolomite rock sequence commonly yield from several tens of gallons per minute to several hundreds of gallons per minute (Melton, 1976). Wells completed in the Potosi Dolomite are capable of yielding from several hundred gallons per minute to as much as $1,000 \mathrm{gal} / \mathrm{min}$ (gallons per minute; Fuller and others, 1967).

General directions of ground-water movement beneath the FLWMR were determined by mapping the water table or potentiometric surface associated with underlying geohydrologic units using measured water levels in wells. Domestic and public-supply wells were inventoried before and during the time groundwater-level measurements were made, and well construction data were collected where possible. Water levels were measured in existing production wells, previously drilled SWMU monitoring wells, and domestic wells. Many water levels were measured in areas bordering the FLWMR to supplement the few water-level measurements available from wells located within the FLWMR. The measurements were made twice, once during seasonal high-base flow conditions and once during seasonal low-base flow condi- tions. Most measured water levels were from wells completed in the Roubidoux Formation-Gasconade Dolomite rock sequence. Only a few wells are completed in the Potosi Dolomite; consequently, there are insufficient data to map the potentiometric surface of ground water in the Potosi Dolomite.

\section{Ground-Water Levels-High-Base Flow}

Water-level measurements were made in domestic and public-water-supply wells located in the general FLWMR area from November 2 to December 2, 1994 , to provide a set of measurements representing ground-water levels during high-base flow conditions. Water levels in six additional wells were measured in the winter and spring of 1995 to complete the data base. Approximately 120 homes and businesses were visited during the survey; however, water levels were measured in only 60 wells because of the inability to gain access to some wells. These measured values of depth to water and the computed water-level altitudes are listed in table 1.

The high-base flow regional ground-water levels between the Big Piney River and Gasconade River (fig. 5) primarily represent hydraulic conditions in the Roubidoux Formation-Gasconade Dolomite rock sequence. A few measurements that represent water levels in the underlying Eminence Dolomite and Potosi Dolomite or a weighted average of water levels in the Roubidoux Formation, Gasconade Dolomite, and underlying Eminence and Potosi Dolomites also are incorporated into the map (for example, measurements from dw 015 and dw 065, table 1).

Water levels exhibit a distinct transition in character between the southern and the northern part of the mapped area. In the southern one-half of the mapped area, water levels generally are higher along the major recharge areas on topographic ridges and are lower toward discharge areas in the major river valleys. The higher levels in the upland areas are supported by the percolation of rainwater through the soil and unsaturated zone of the upland areas. The rate of groundwater flow away from the upland recharge areas is determined by the bedrock permeability. Groundwater flow is perpendicular to the contour lines of equal hydraulic head, or water-level altitude, and is directed to regional streams where the ground water discharges. The slight offset of the regional groundwater divide between the Big Piney River and Roubidoux Creek west of the regional topographic divide 


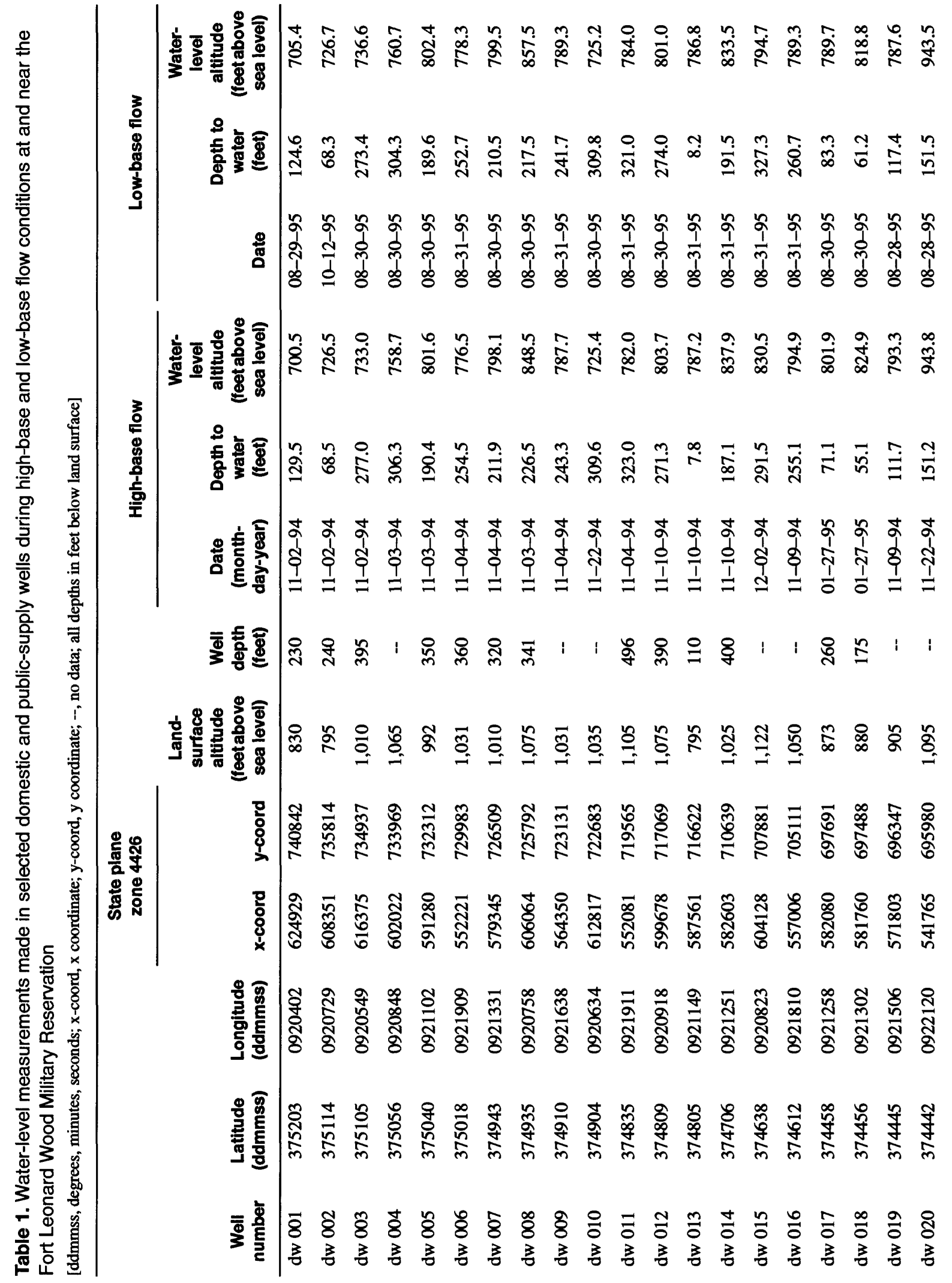




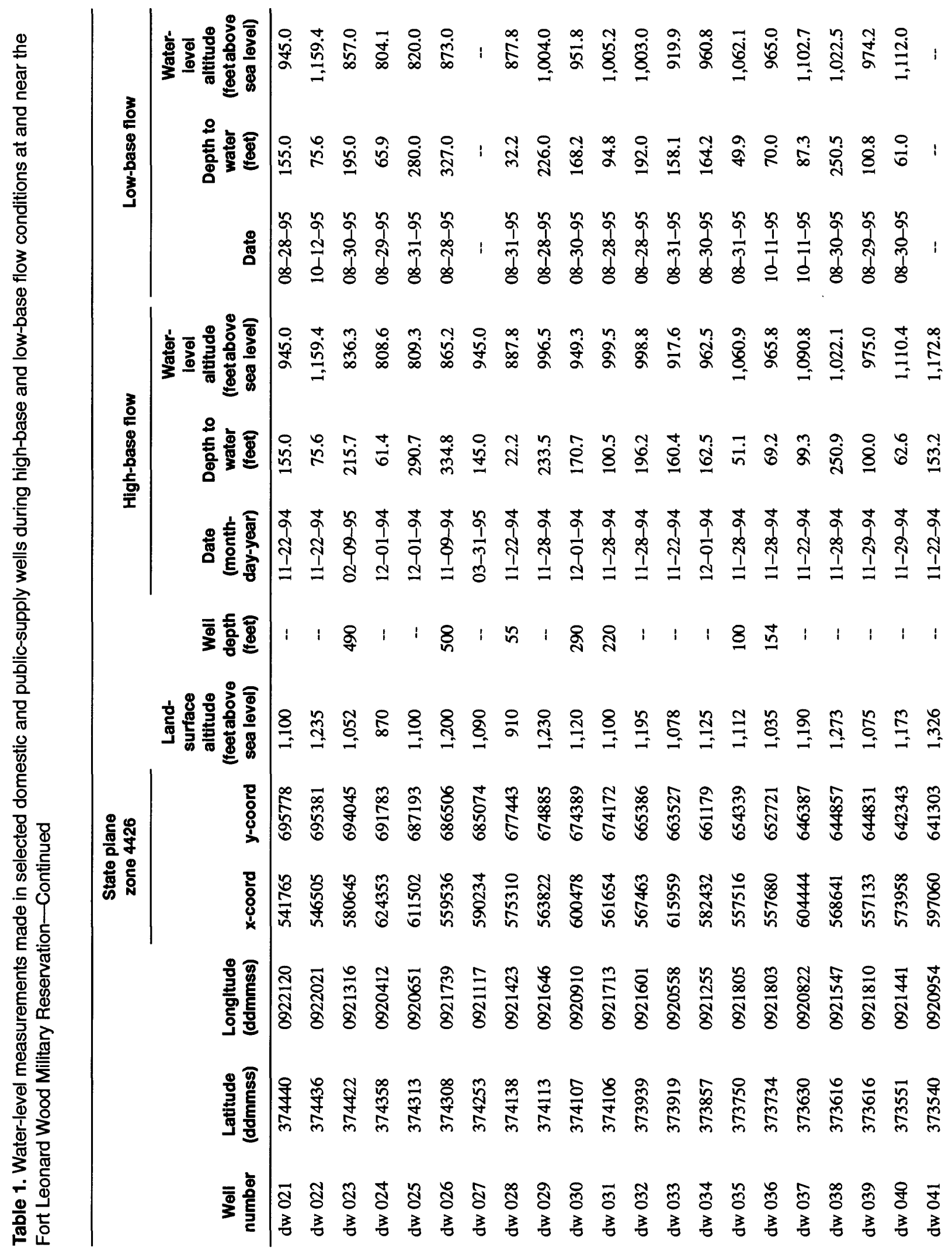




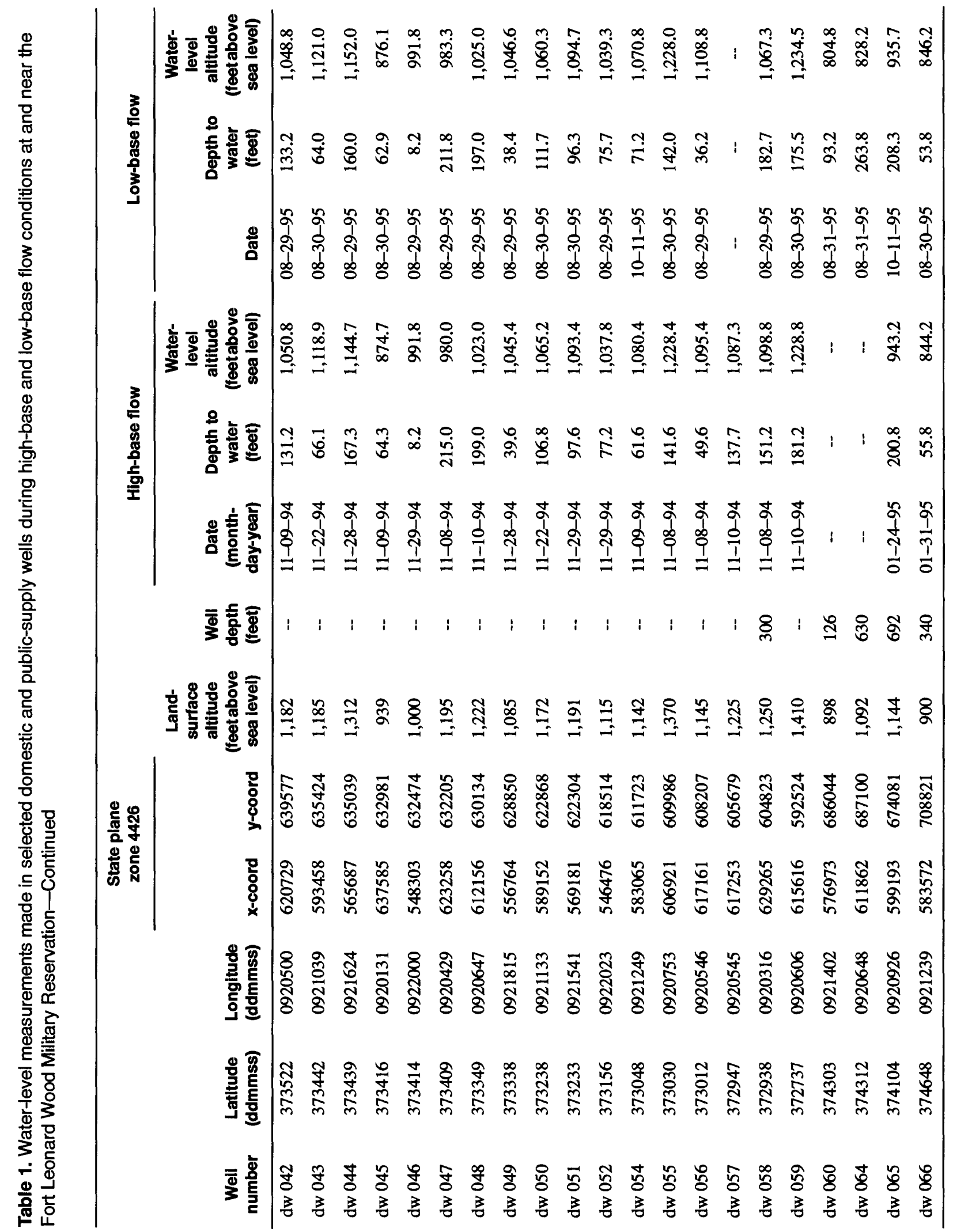




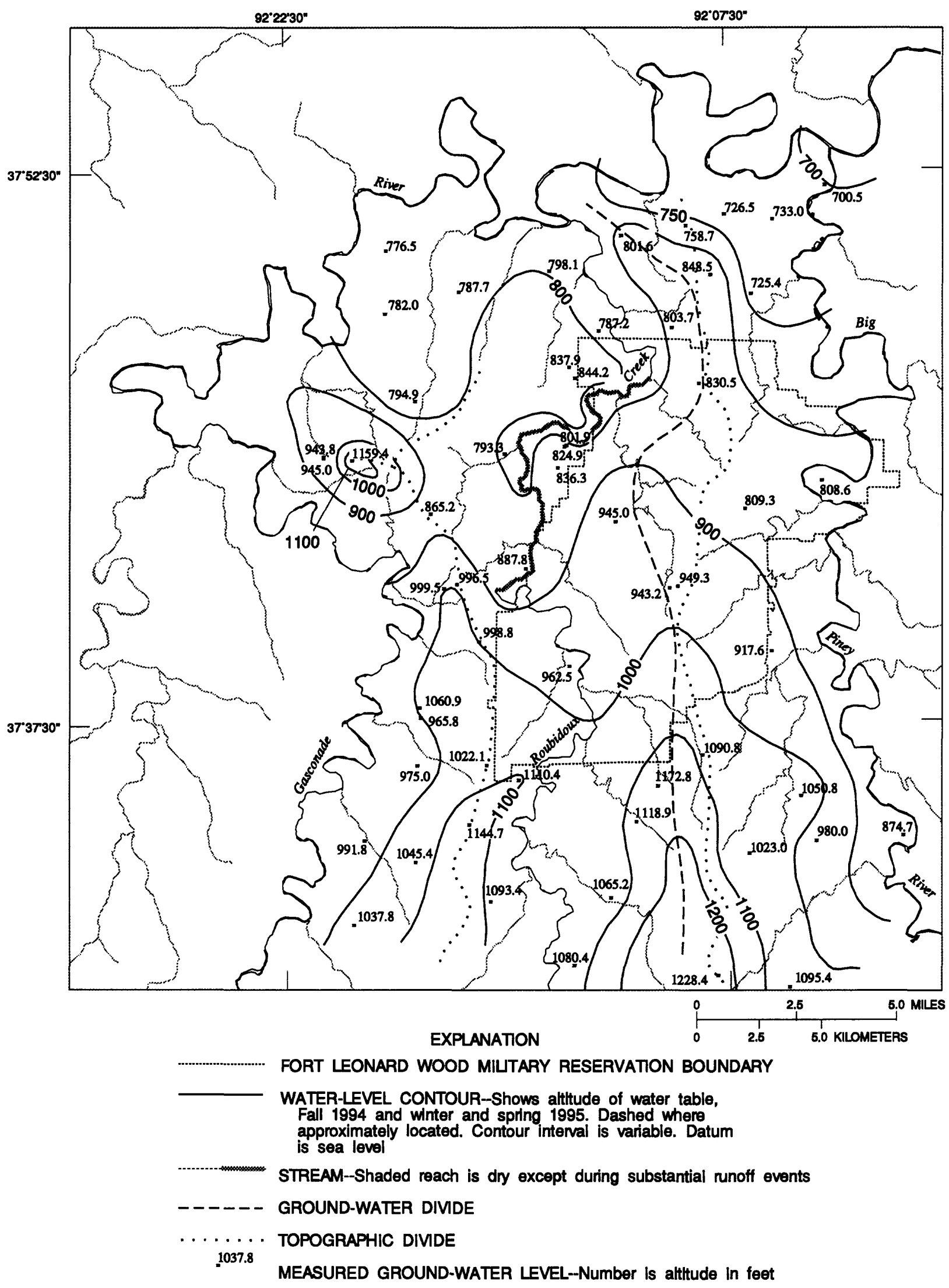

Figure 5. Altitude of shallow ground-water levels at and near the Fort Leonard Wood Military Reservation during high-base flow conditions. 
indicates that bedrock permeability generally may be larger in the Big Piney River Basin. Ground-water levels south of the FLWMR are greater than $1,100 \mathrm{ft}$ above sea level between the Big Piney River and Roubidoux Creek valleys and between the Gasconade River and Roubidoux Creek valleys. Apparently, all three streams receive ground-water discharge in this part of the mapped area.

In the central part of the FLWMR, the regional ground-water divide is as much as $2 \mathrm{mi}$ west of the regional topographic divide. The large lateral separation between the ground-water and topographic divides indicates a substantially larger bedrock permeability in the east-central part of the FLWMR than in the west-central part. Evidence for this increased permeability is the unusually low water level $(809.3 \mathrm{ft}$ above sea level) measured in the old ammunition dump well ( $\mathrm{dw}$ 025) and the large concentration of sinkholes (fig. 3) that indicate the presence of a welldeveloped karst terrane throughout the central and northeastern parts of the FLWMR. The major effects of the secondary permeability zone are to redirect ground water that normally would have flowed westward to Roubidoux Creek eastward to the Big Piney River and to redirect ground water that would have flowed eastward to the Big Piney River more northward toward Shanghai Spring. More evidence of this flow pattern will be presented during the discussion of dye-trace investigations and streamflow measurements. Water-level contours in the extreme north-central part of the FLWMR are more typical of an area where flow is not dominated by karst; that is, flow is east and west from a ground-water divide that is beneath the regional topographic divide. However, karst features are not absent from this area.

The small oval-shaped mound of ground water about $5 \mathrm{mi}$ west of the FLWMR probably is caused by the presence of low permeability material in the topographically high area centered on the mound. The single measured water level $(1,159.4 \mathrm{ft}$ above sea level) on which the contoured mound primarily is based is more than $200 \mathrm{ft}$ above water levels measured in nearby wells. Although the depth of this well is not known, it is likely that the well is shallow (perhaps less than $100 \mathrm{ft}$ deep) and the water-level measurement is not representative of hydraulic heads in the lower part of the Roubidoux Formation and Gasconade Dolomite. Water levels north of the mound are low (less than $800 \mathrm{ft}$ above sea level) and quite uniform throughout an area that includes a major topographic ridge and the Gasconade River valley. The water levels exhibit a small northward gradient toward the Gasconade River. The presence of such a uniform waterlevel surface within an area of large relief (about 400 $\mathrm{ft}$ ) indicates a substantial increase in bedrock permeability consistent with greatly enhanced bedding-plane permeability by widespread dissolution of one or more carbonate beds. The enhanced permeability alters surface-water flow in the Gasconade River and is observable using dye-trace investigations. Evidence of the effect of the increased permeability on flow patterns will be presented during the discussion of dye-trace investigations and streamflow measurements.

\section{Ground-Water Levels-Low-Base Flow}

Water-level measurements were made during low-base flow conditions in selected domestic and public-water-supply wells from August 28 to August 31,1995 . Water levels in six additional wells were measured October 11 and 12,1995, to complete the data base. Depth-to-water measurements and the computed water-level altitudes during low-base flow conditions are listed in table 1.

The mapped low-base flow regional groundwater levels (fig. 6) primarily represent hydraulic conditions in the Roubidoux Formation-Gasconade Dolomite rock sequence and differs little from the mapped ground-water-level measurements during high-base flow conditions (fig. 5). The most notable difference between these two sets of measurements is that the water levels during low-base flow conditions within and near the northern FLWMR boundary are about 35 $\mathrm{ft}$ lower than water levels during high-base flow conditions. The character of the water-level surface in this area is almost solely based on measurements in the main supply well for the FLWMR (Indiana Avenue well, dw 015). Water-level measurements typically are taken only after the pump has been turned off for about one-half hour or more. The much lower water level measured in well dw 015 during low-base flow conditions possibly represents the regional effect of the operating well during a period of increased water use, not the direct effect of dryer climatic conditions.

Lower water levels (about $10 \mathrm{ft}$ ) also were measured during low-base flow conditions in two wells in the Roubidoux Creek valley. The lower level may be caused by decreased ground-water flow into the extremely permeable rock beneath the dry stream channel in this part of the valley and continued north- 


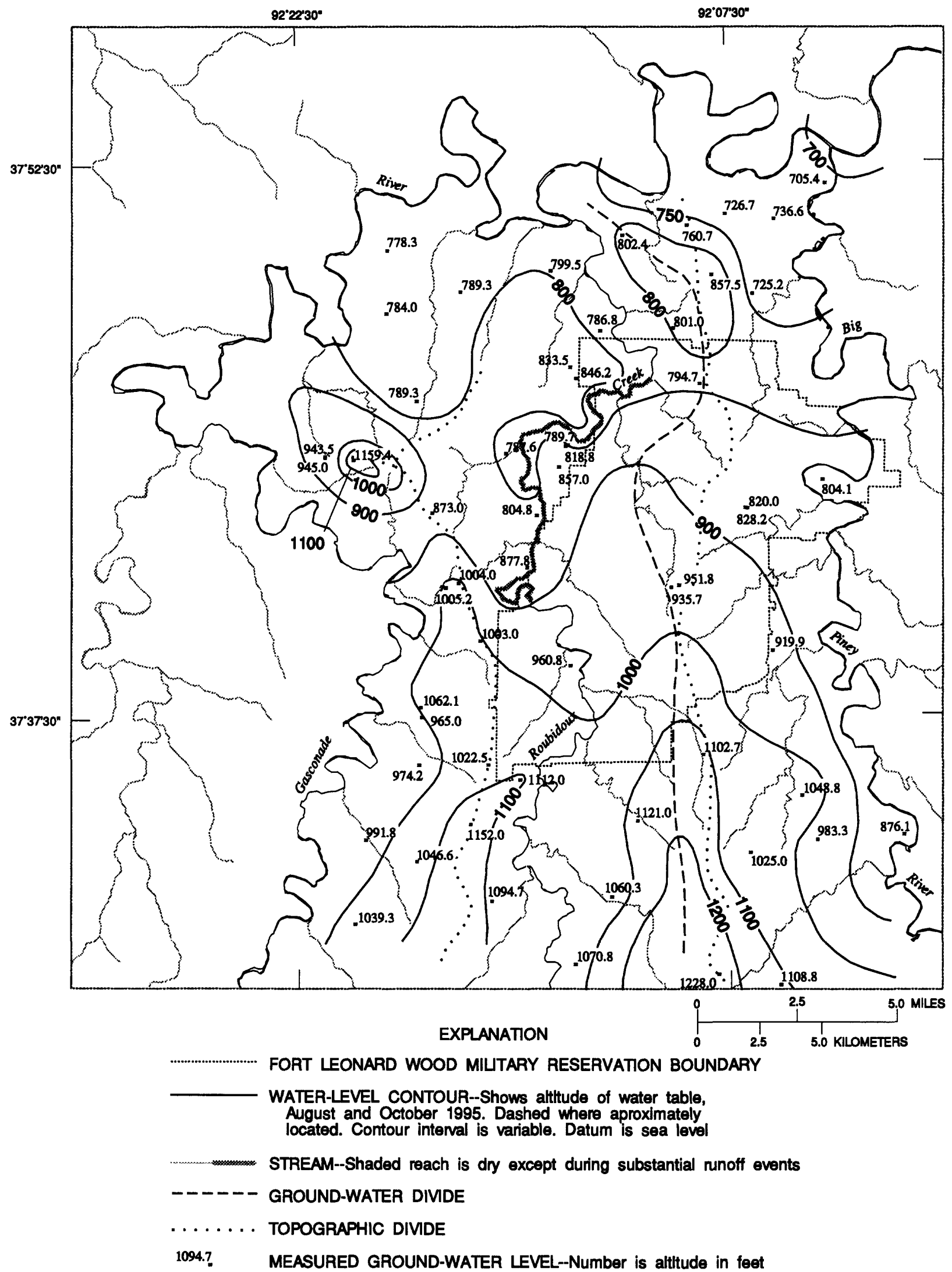

Fgure 6. Altitude of shallow ground-water levels at and near the Fort Leonard Wood Military Resenvation during low-base fiow conditions. 
ward drainage of the water through large fractures and conduits. However, in general, most measured groundwater-level changes from high- to low-base flow conditions were small, especially in upland areas. A possible explanation is that ground-water storage in the karst terrane is large and the system has the capacity to supply substantial quantities of water to discharge points, such as springs, for sustained periods of decreased rainfall.

\section{Vertical Ground-Water Flow}

Three well pairs included in the regional ground-water-level survey provide an opportunity to estimate vertical hydraulic-head differences at these locations. The wells comprising each well pair are located within a few hundred feet of one another and are completed in different geologic formations. Wells $\mathrm{dw} 017$ and dw 018 (table 1) are located at the westcentral border of the FLWMR and were drilled about $200 \mathrm{ft}$ apart; well dw 018 is completed in the middle part of the Gasconade Dolomite and well dw 017 in the lower part of the Gasconade Dolomite. During high-base flow conditions, the water level in the shallower well was about $20 \mathrm{ft}$ higher than levels in the deeper well ( 824.9 and $801.9 \mathrm{ft}$ above sea level). During low-base flow conditions, the water level in the shallower well was about $30 \mathrm{ft}$ higher than the level in the deeper well ( 818.8 and $789.7 \mathrm{ft}$ ). The vertical hydraulic gradient in this area was downward to the base of the Gasconade Dolomite.

Another well pair is located at an ammunition dump in the east central part of the FLWMR (table 1, wells $d w 025$ and $d w$ 064). These wells are about 100 $\mathrm{ft}$ apart. The exact depth of the shallower well is not known; however, the well is reported to have been drilled a short distance into the Eminence Dolomite (about $400 \mathrm{ft}$ deep). The deeper well was completed at $630 \mathrm{ft}$ in the Potosi Dolomite and was cased to $488 \mathrm{ft}$ (middle part of the Eminence Dolomite). Because the deeper well was drilled after the water-level measurements were completed during high-base flow conditions, only water levels during low-base flow conditions were obtained at the well. Under low-base flow conditions, water levels in the shallower well were about $8 \mathrm{ft}$ lower than levels in the deeper well $(820.0$ and $828.2 \mathrm{ft})$. The vertical hydraulic gradient in this area was upward from the Potosi Dolomite to the Gasconade Dolomite. However, in this part of the FLWMR, water levels in the Roubidoux Formation and Gasconade Dolomite are relatively low because the large permeability caused by dissolution of the carbonate rock in this area effectively drains ground water rapidly to nearby springs. In the absence of such a well-developed karst terrane, the vertical gradient possibly would be downward.

The third well pair is located in the south-central FLWMR (table 1, wells dw 030 and dw 065). These wells are located about 1,300 ft apart. The depth of the shallower well is $290 \mathrm{ft}$ and is cased to $82 \mathrm{ft}$ deep. This well is completed in the middle part of the Gasconade Dolomite. The deeper well was completed to a depth of $692 \mathrm{ft}$ in the Potosi Dolomite and was cased to 295 $\mathrm{ft}$ (also in the middle part of the Gasconade Dolomite). Unfortunately for this analysis, the deeper well is open to both the Gasconade Dolomite and Potosi Dolomite, and a clear distinction between water levels in the two formations cannot be made. During high-base flow conditions, water levels in the shallower well were about $6 \mathrm{ft}$ higher than levels in the deeper well (949.3 and $943.2 \mathrm{ft}$ ). During low-base flow conditions, water levels in the shallower well were about $16 \mathrm{ft}$ higher than levels in the deeper well (951.8 and $935.7 \mathrm{ft})$. The vertical hydraulic gradient in this broad upland apparently was downward from the Gasconade Dolomite to the Potosi Dolomite.

Based on the scant data available and by comparison with regional ground-water flow patterns and flow patterns in nearby areas of similar geologic conditions, vertical hydraulic gradients generally are thought to be downward from the Gasconade Dolomite to the Potosi Dolomite in the FLWMR area. These gradients probably are small. Where the highly permeable karst terrane in the Roubidoux Formation and Gasconade Dolomite rapidly transports ground water through conduits to local points of discharge (springs), hydraulic heads in these formations are lowered and can locally be lower than heads in the Potosi Dolomite. In these local areas, vertical hydraulic gradients can be upward into the Gasconade Dolomite.

\section{Dye-Trace Investigations of Fracture and Conduit Flow}

Ground-water flow at the FLWMR is a complex combination of flow through porous residual material and bedrock and flow through hydraulically active fractures and along solution-enlarged openings between bedding planes. Ground-water flow in a hydrologic system of this complexity often is difficult 
to fully understand based solely on potentiometric data. The small number of water wells on the FLWMR and low density of accessible water wells around the FLWMR relative to the large size of the study area make the construction of detailed and accurate potentiometric maps difficult. Dye-tracing techniques were, therefore, used to supplement water-level measurements and provide direct evidence of hydraulic connectivity between specific ground-water recharge areas, such as sinkholes, and major ground-water discharge points, such as springs. Dye-trace investigations are a valuable method of determining groundwater flow directions and rates in a karst terrane and for delineating spring catchment areas.

At least five dye-trace tests are known to have been conducted in or near the FLWMR before this study began. These tests are labeled HT-01 to HT-05 on figure 7. The injection point for dye-trace test HT01 (Harvey, 1980, p. 34-35) was the point at which Roubidoux Creek loses flow under low-base flow conditions. The injected dye was recovered at Roubidoux Spring, about $10.5 \mathrm{mi}$ north of the injection site, about 5 days after injection. Dye for dye-trace test HT-02 (Harvey, 1980, p. 34-35) was injected into a tributary of Dry Creek near St. Robert (fig. 1) and was recovered at Shanghai Spring $2.8 \mathrm{mi}$ to the northeast. Dyetrace test HT-03 (Harvey, 1980, p. 34-35 and p. 3637) was made to determine if wastewater from the FLWMR sewage treatment plant (STP) was being transported to Shanghai Spring. Dye injected into the sewage outflow, which is discharged into Dry Creek, was recovered at Shanghai Spring $2.5 \mathrm{mi}$ to the northnortheast. Dye-trace test HT-04 (Rory McCarthy, FLWMR, written commun., 1995) was conducted by MDGLS after a sinkhole in the northeast part of a small lake collapsed and drained part of the lake. Dye injected into the sinkhole was recovered at Shanghai Spring $9.0 \mathrm{mi}$ northwest of the lake, indicating an interbasin transfer of water across the central surfacewater divide of the FLWMR. Dye for tracer test HT-05 (unpublished data on file at the MDGLS) was injected into a sinkhole near the upper edge of Range 19 Lake and was recovered at Miller Spring 3.0 mi east of the injection site.

Seven tests using fluorescent dyes were conducted during this study between February and September 1995. Dye injection locations at the FLWMR generally were chosen based on the availability of a substantial opening through the unsaturated zone to the water table. Visual evidence of such openings include the presence of water-formed conduits in the bottom of sinkholes and substantial loss of streamflow over short distances. Although many sinkholes are present throughout the northern one-half of the FLWMR, most of these sinkholes are not suitable as injection sites because the sinkhole bottom is sealed by residuum and clay soils. Sinkholes north of Forney Army Airport, beyond the northern extent of Jefferson City Dolomite bedrock (fig. 2), are more likely to be open or to be filled by more-permeable friable soils and plant root mats. Dye recovery detection was attempted at downgradient perennial streams, springs, and seeps associated with ground-water discharge to the Big Piney River, Roubidoux Creek, Gasconade River, and their tributaries.

Background fluorescent spectra checks and attempted dye recoveries were made by placing approximately $10 \mathrm{~g}$ (grams) of activated coconut charcoal encased in a fiberglass mesh into flowing surface water. The charcoal packets were kept immersed from a few days to about 2 weeks. After retrieval from the water, each charcoal packet was washed with clean water, dried, and split into two samples of approximately equal weight. One-half of the sample was archived in case the analysis needed to be repeated. The other one-half was eluted in a solution of 95 percent isopropyl alcohol and 5 percent ammonium hydroxide by volume. The elutant solution was analyzed for the presence of fluorescent materials using a scanning spectrofluorophotometer adjusted to illuminate the solution using a range of excitation wavelengths from 300 to $650 \mathrm{~nm}$ (nanometers) and monitor the fluorescence (emission) spectra from 320 to 670 $\mathrm{nm}$ using a 3-nm window at a $+20-\mathrm{nm}$ shift from the excitation wavelength. All analyses were qualitative. The reader is referred to Mull and others (1988) for a review of standard dye-tracing techniques.

Before dye was injected into the ground-water flow system, a series of preliminary background checks for fluorescent materials were made at several potential dye-recovery sites north and east of the FLWMR. The background check sites (fig. 8) included 11 sites in the Big Piney River Basin (Shanghai Spring, Dry Creek at the STP outflow, the "Boy Scout Camp" tributary, the pumping station spring, the "Asphalt Plant" stream, Miller Spring, and 5 locations on the Big Piney River) and 8 sites in the Roubidoux Creek Basin (Roubidoux Spring, Ballard Hollow stream, and six locations on Roubidoux Creek). Background checks were conducted on a few additional 


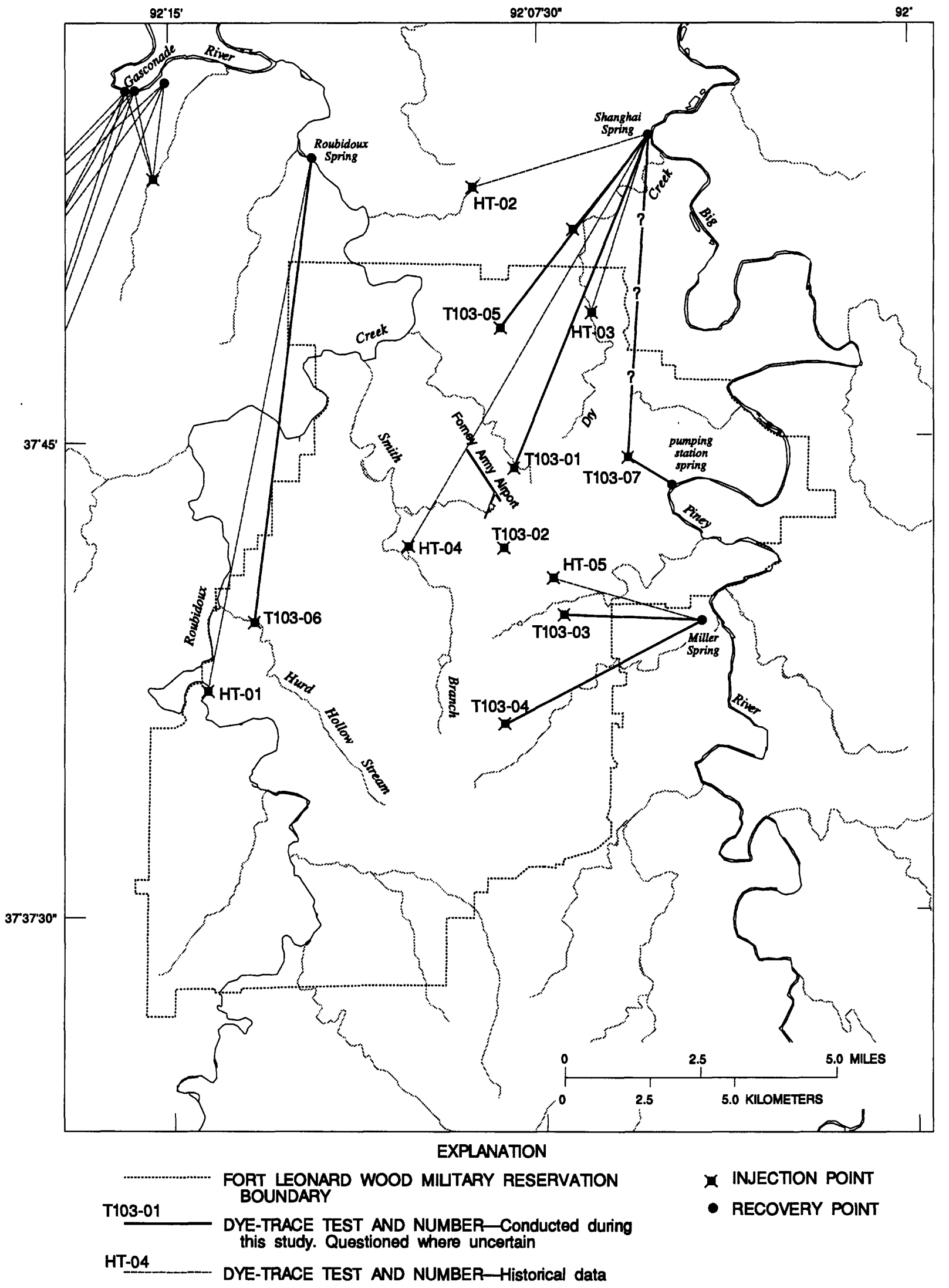

Figure 7. Injection and recovery points for dye-trace tests T103-01 to T103-07 and historical dye-trace tests at and near the Fort Leonard Wood Military Resenvation. 


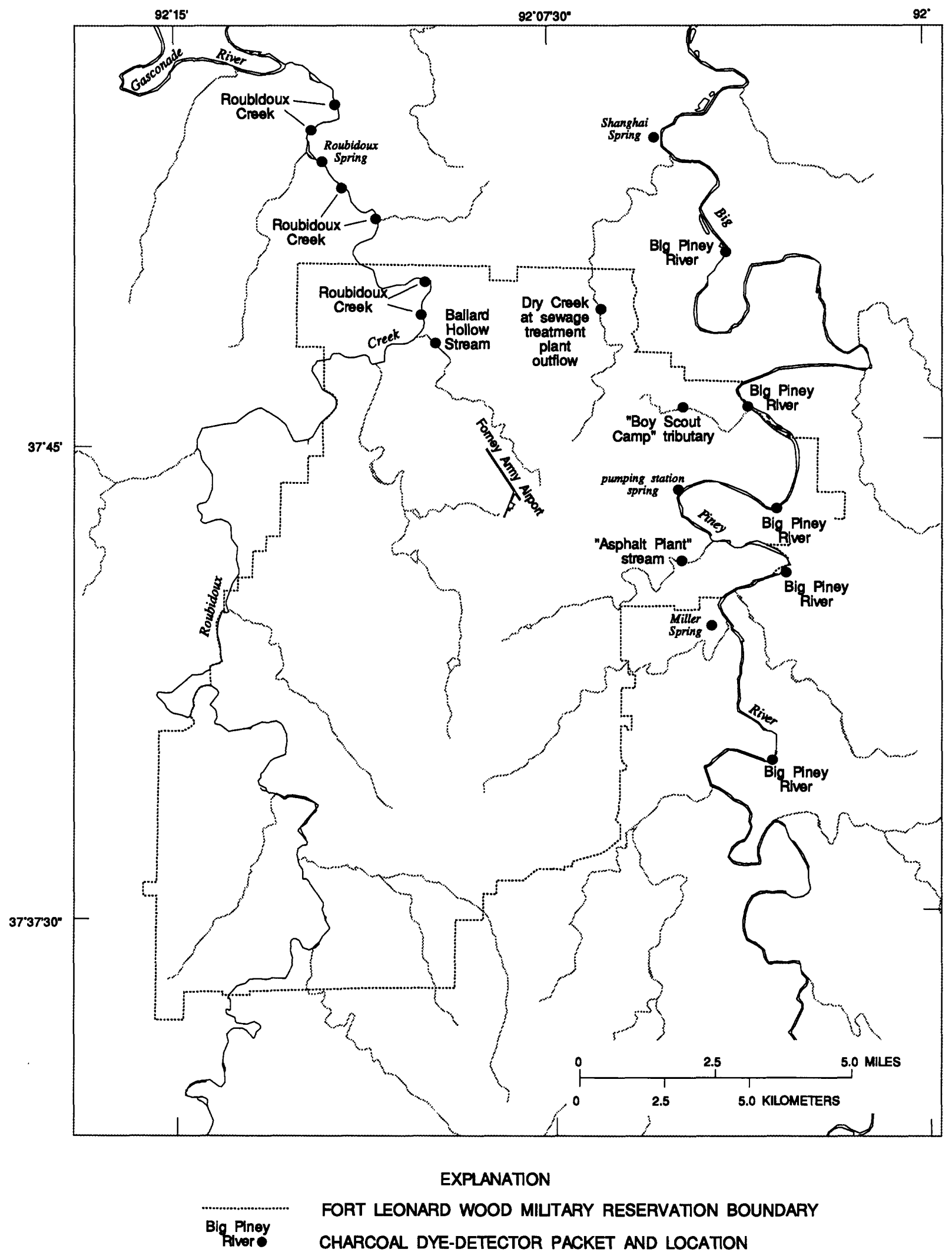

Figure 8. Distribution of charcoal packets placed in surface water and springs for monitoring of background dye concentrations at and near the Fort Leonard Wood Military Reservation. 
sites (Creasy Spring, Stone Mill Spring, Bartlett Mill Spring, Ousley Spring, and Road FLW 32 unnamed spring, fig. 3) during the investigation because it became necessary to incorporate new potential dyerecovery sites into the network. Background checks also were repeated at each potential recovery site incorporated into a dye-trace test to determine whether residual dye concentrations from a previous dye-trace test had sufficiently decreased before the injection of more dye into the flow system. The typical background fluorescence spectra for preliminary background check samples were a broad low-intensity peak centering on an emission wavelength of about $440 \mathrm{~nm}$. However, three of the sites (Shanghai Spring, Dry Creek at the STP outflow, and the pumping station spring) had well-defined fluorescence peaks at about $520 \mathrm{~nm}$. This wavelength is consistent with the presence of fluorescein dye and may be derived from household cleaning products or automotive antifreeze. The background fluorescence spectra at Shanghai Spring were nearly identical to that at the STP outflow, indicating that outflow from the STP enters the ground-water flow system through the Dry Creek streambed and resurges at Shanghai Spring (fig. 7, trace HT-03).

Dye injection for the first dye-trace test (T10301, fig. 7) was on February 14, 1995. Preparation for the dye-trace test included an additional background check at nine potential recovery sites a few days before the dye injection. The test was performed by injecting $3 \mathrm{~L}$ (liters) of Rhodamine WT dye in a large sinkhole located about $0.75 \mathrm{mi}$ north of Forney Army Airport control tower. Rhodamine WT dye was used because its fluorescence peak wavelength $(567 \mathrm{~nm})$ is higher than the wavelength of detected background fluorescent materials at Shanghai Spring, a site at which dye recovery was anticipated. A pre-injection flush of $100 \mathrm{gal}$ (gallons) of water and post-injection flush of $400 \mathrm{gal}$ of water were used to quickly move the dye through the unsaturated zone. The maximum concentration of Rhodamine WT dye was detected at Shanghai Spring from February 24 to 27, 1995. Travel time from the injection site and Shanghai Spring, a lateral distance of $6.55 \mathrm{mi}$ and altitude difference of about $360 \mathrm{ft}$, was 10 to 13 days. Dye was not detected at eight other recovery sites. The relatively short time for the dye pulse to pass through Shanghai Spring (3 days) indicates that water primarily is transported from the injection site to the spring through a single well-defined fracture or bedding-plane opening. Dye concentrations before and after these 3 days were small relative to the maximum dye concentration. The estimated ground-water flow rate is about $0.5 \mathrm{mi}$ per day. A summary of the dye-trace injection and recovery data for T103-01 is presented in tables 2 and 3, at the back of this report. The relative fluorescence intensity of dye eluted from charcoal packets placed in Shanghai Spring during the dye-trace test is shown in figure 9.

A second dye-trace test (T103-02, fig. 7) was conducted by injecting Rhodamine WT dye into a small (about 6-ft diameter) sinkhole in a wooded area at the south edge of SWMU FLW-003 on March 16, 1995. This site was chosen in an attempt to conduct a dye-trace test from the immediate vicinity of FLW003, FLW-004, and FLW-005, landfills under investigation during the same time as the regional geohydrologic assessment was being conducted. It was understood that this was not an ideal site for dye injection. Although the large rocks and gravel that filled the bottom of the sinkhole did not completely restrict flow into the subsurface, the infiltration rate was small, and there was no certainty that flow to the water table was unimpeded. Background dye concentrations at potential recovery sites were checked before the dye-trace test was conducted. Dye concentrations at Shanghai Spring had receded to background concentrations. Approximately $4 \mathrm{~L}$ of Rhodamine WT dye were used in the injection, which included a 600 -gal post-injection flush. Potential recovery sites (table 4, at the back of this report) were monitored for Rhodamine WT dye for about 4 months after the injection date. No dye was recovered from this injection. The only indication that dye recovery might be successful was during analysis of charcoal packets collected from Shanghai Spring on May 12, 1995. Fluorescence spectra from this analysis showed a previously undetected peak at $572 \mathrm{~nm}$; however, the peak intensity was extremely small and may have been caused by residual dye from dye-trace test T103-01. Packets collected from Shanghai Spring on May 15 and 19, 1995, also indicated the peak at the same small intensity. The peak was not present in analyses of packets recovered after May 19, 1995. The movement of the dye to the water table was assumed to have been impeded by clayey residuum and bound into the clay matrix.

A third dye-trace test (T103-03, fig. 7) was initiated on April 17, 1995, with the injection of $2 \mathrm{lbs}$ (pounds) of fluorescein dye into an opening at the northeastern side of a large sinkhole located about 300 


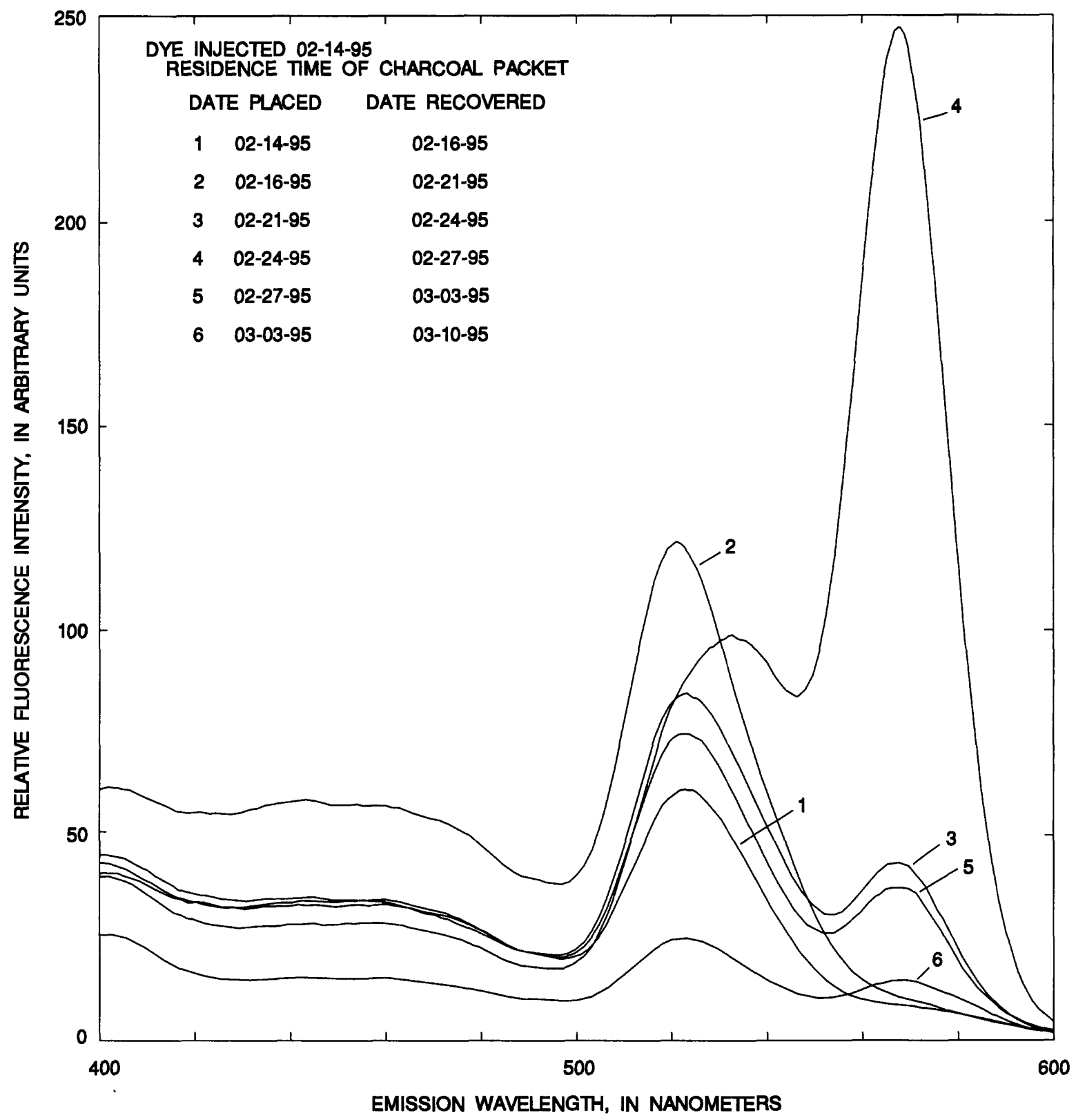

Fgure 9. Spectral analysis of fluorescent material extracted from activated charcoal packets placed in Shanghai Spring during dye-trace test T103-01.

$\mathrm{ft}$ south of Bradford Cemetery. The injection process included a 100-gal pre-injection flush and 500-gal post-injection flush. Fluorescein dye was used in this test to maintain distinction from the ongoing dye-trace test T103-02, which used Rhodamine WT dye. The injected dye was recovered at Miller Spring, located 3.93 mi east of the sinkhole at an altitude of about 240 $\mathrm{ft}$ lower than the sinkhole, about 4 days after injection. The estimated ground-water flow rate is about $1 \mathrm{mi}$ per day. Dye-trace injection and recovery data for T10303 are presented in tables 5 and 6, at the back of this report. Relative fluorescence intensity of dye eluted from charcoal packets collected at Miller Spring during a 3-week period after injection is shown in figure 10.

A fourth dye-trace test (T103-04, fig. 7) was conducted on May 9, 1995, with the injection of 2.5 lbs of fluorescein dye into a small sinkhole that is the easternmost of a series of four sinkholes extending nearly parallel to a dirt and gravel road along the northern boundary of a small arms firing range. Fluorescein dye again was used in this test to maintain distinction from on-going dye-trace test T103-02. A small opening in the bottom of the sinkhole provided 


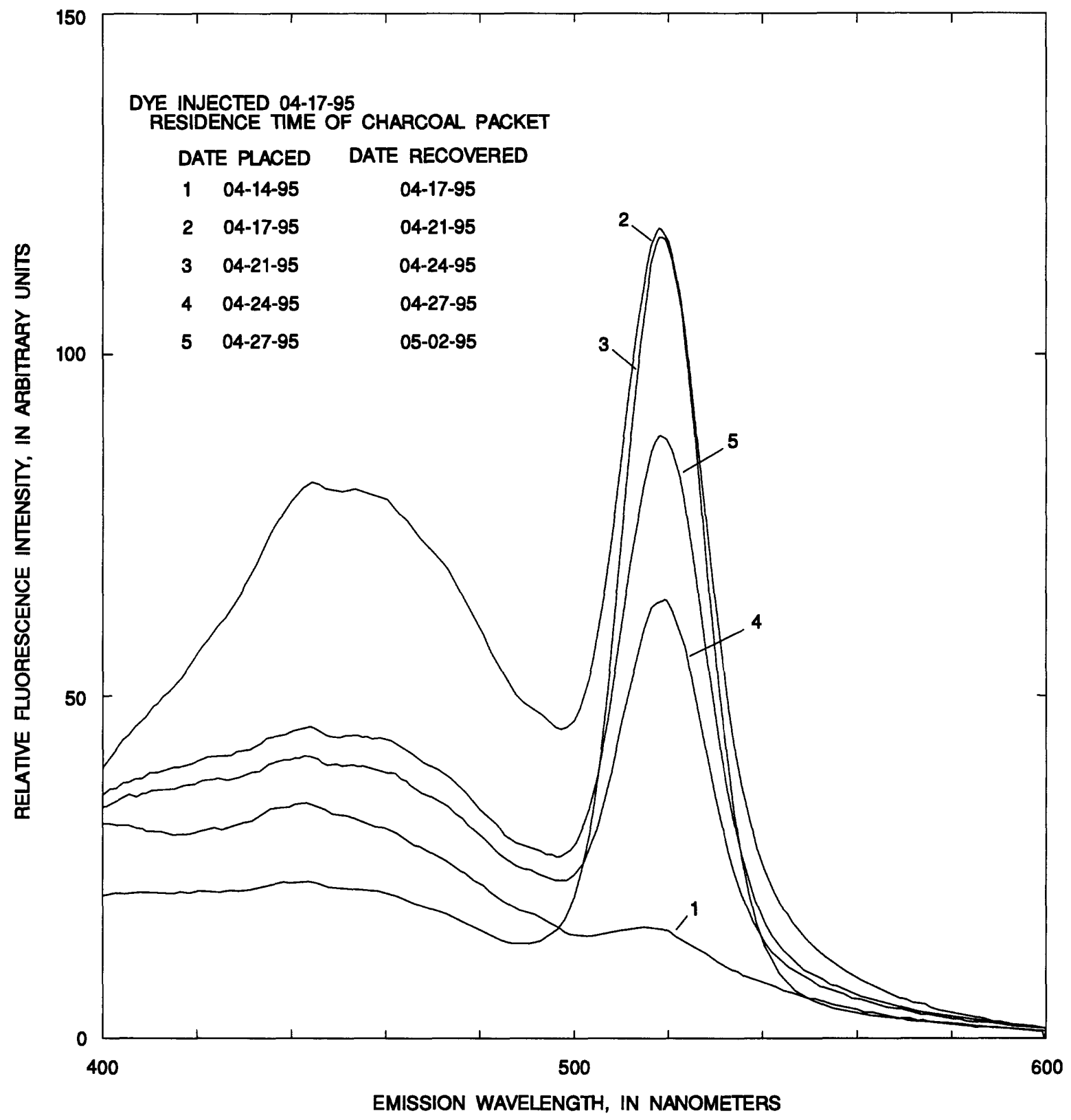

Fgure 10. Spectral analysis of fluorescent material extracted from activated charcoal packets placed in Miller Spring during dye-trace test T103-03.

access to a 10 - to 15 -ft deep cavity beneath the sinkhole. Dye injection was followed by a flush of $500 \mathrm{gal}$ of water to rapidly move the dye into the saturated zone. The injected dye was recovered at Miller Spring. Maximum dye concentrations at Miller Spring as indicated by the intensity of fluorescence spectra occurred about 13 days after injection; however, substantial concentrations of dye were detected at the spring from about 3 days after injection until about 25 days after injection. Miller Spring is located $4.08 \mathrm{mi}$ northeast of the sinkhole. The ground-water flow rate along the path carrying the greatest dye load is about $0.3 \mathrm{mi}$ per day. Dye-trace injection and recovery data for T10304 are presented in tables 7 and 8, at the back of this report. The relative fluorescence intensity of dye eluted from charcoal packets collected at Miller Spring during the dye-trace test is shown in figure 11.

A fifth dye-trace test (T103-05, fig. 7) was conducted on May 26, 1995, with the injection of 1.25 to $1.50 \mathrm{lbs}$ of fluorescein dye into a sinkhole located about $100 \mathrm{ft}$ north of the west end of Pulaski Avenue in the northwestern corner of the cantonment area. The dye was placed in an opening beneath a large tree growing from the southern bank of the sinkhole. Fluo- 


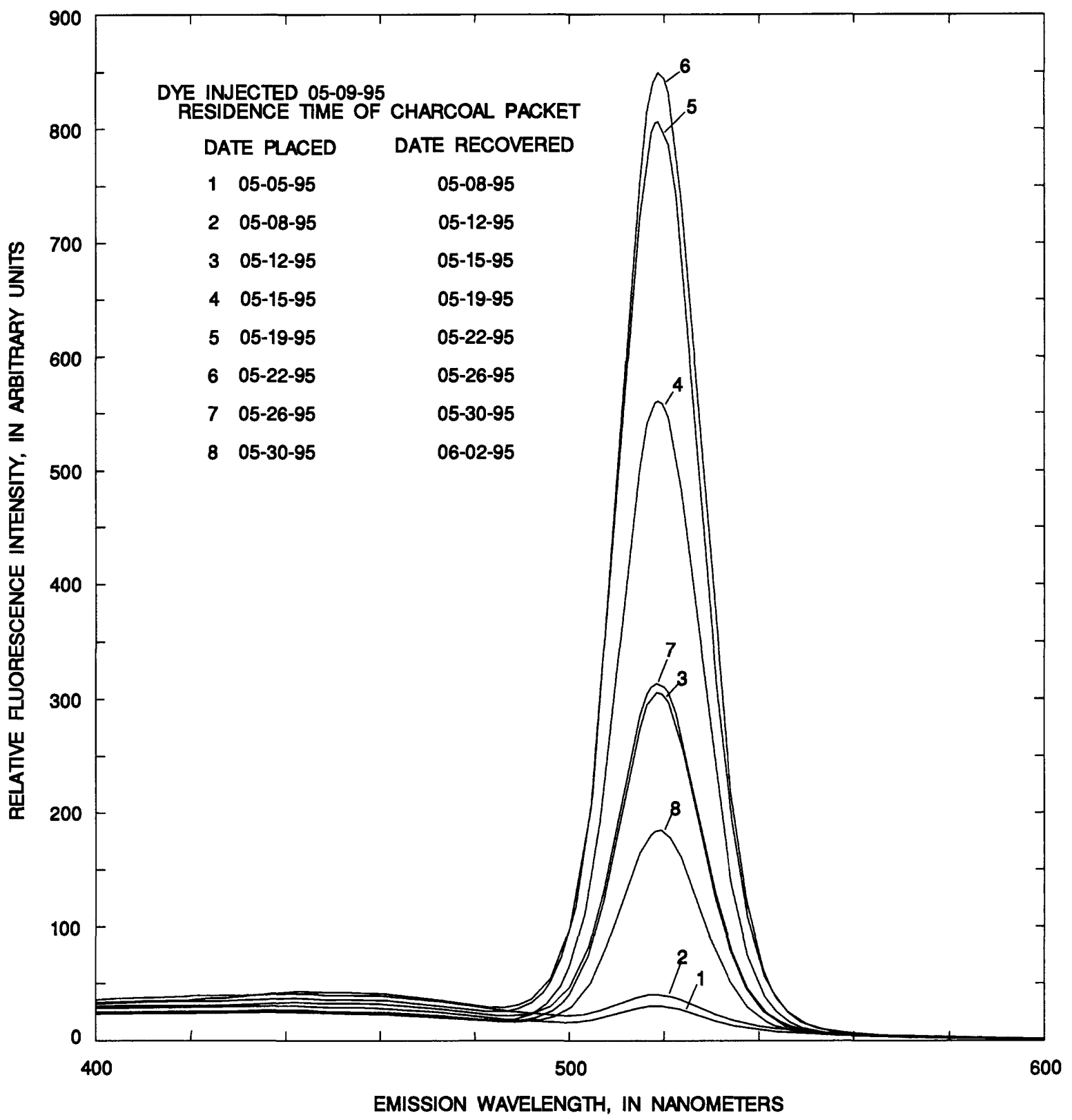

Figure 11. Spectral analysis of fluorescent material extracted from activated charcoal packets placed in Miller Spring during dye-trace test T103-04.

rescein dye was used in this test to maintain distinction from dye-trace test T103-02. The injection site was flushed with 50 gal of water before injection and 450 gal after injection. The injected dye was recovered at Shanghai Spring from about 4 to 29 days after injection, with peak concentrations occurring about 10 to 14 days after injection. The altitude of Shanghai Spring is $295 \mathrm{ft}$ lower than the injection sinkhole. The slower rise and fall of peak dye concentrations at the spring as compared to dye-trace test T103-01 indicates a more complex multi-channel flow path from the Pulaski Avenue sinkhole to Shanghai Spring than from the Forney Army Airport sinkhole to Shanghai Spring. The ground-water flow rate along the path carrying the greatest dye load is about $0.4 \mathrm{mi}$ per day. Shangai Spring is located $4.49 \mathrm{mi}$ northeast of the sinkhole. Dye-trace injection and recovery data for T103-05 are presented in tables 9 and 10, at the back of this report. Relative fluorescence intensity of dye eluted from charcoal packets collected at Shanghai Spring for 6 weeks after injection is shown in figure 12 .

Dye-trace test T103-06 (fig. 7) was begun July 6,1995, and completed in August 1995. The dye, 1 gal of Rhodamine WT, was injected into a losing stream in 


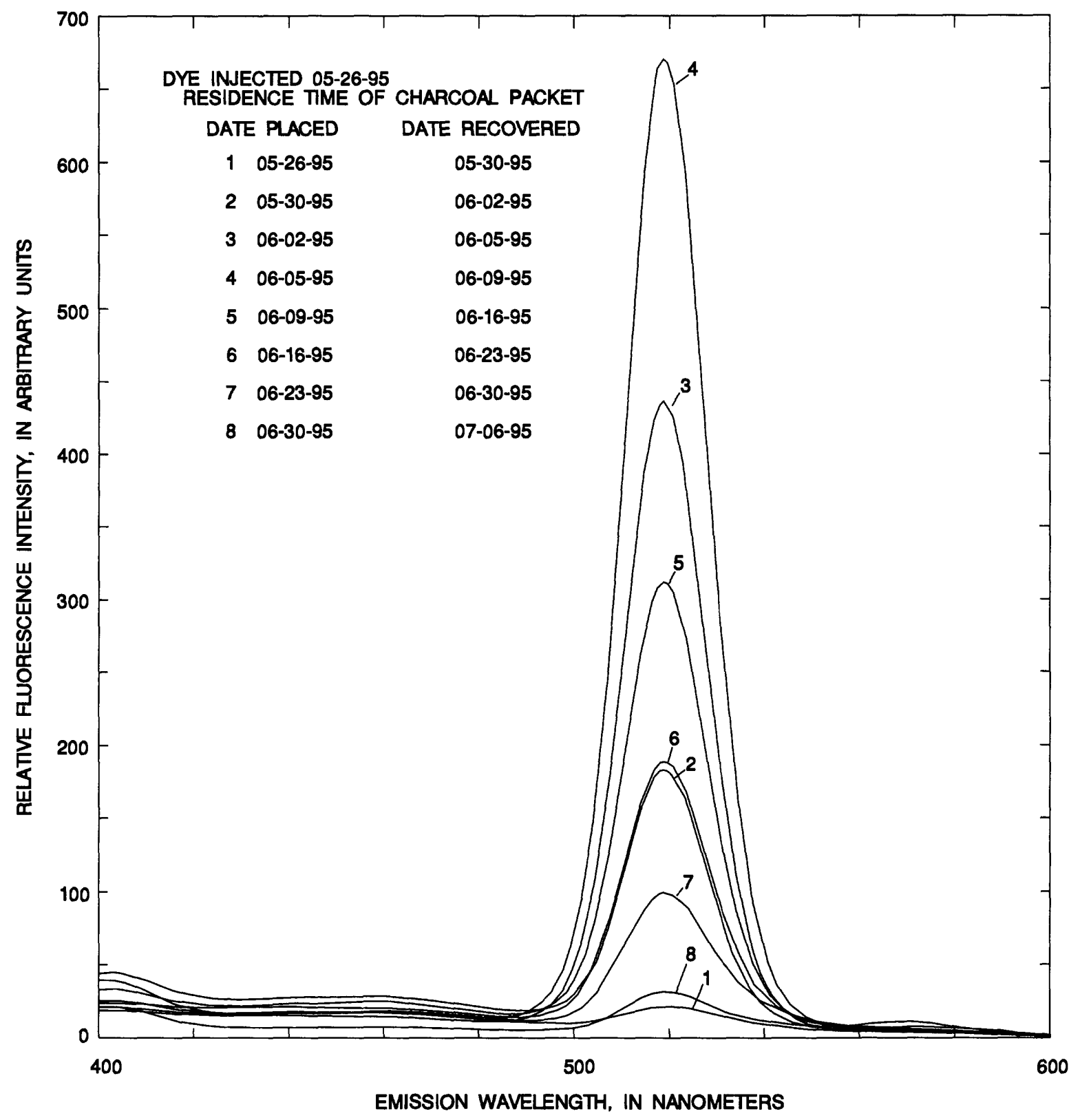

Figure 12. Spectral analysis of fluorescent material extracted from activated charcoal packets placed in Shanghai Spring during dye-trace test T103-05.

Hurd Hollow near the location of complete flow loss. Dye was recovered at Roubidoux Spring at an altitude $132 \mathrm{ft}$ lower that the Hurd Hollow injection site about 8 to 15 days after injection. Dye concentrations before and after the 8- to 15-day travel time were small as compared to the peak concentrations. The groundwater flow rate along the path carrying the greatest dye load is estimated at 0.5 to $1 \mathrm{mi}$ per day. No dye was recovered from Roubidoux Creek between Roubidoux Spring and the point at which flow returns near Ballard Hollow, which indicates that the source of water in
Roubidoux Creek downstream from the long dry reach (fig. 6) is discharge of shallow ground water from nearby upland areas. Surface water that flows into the karst terrane beneath Roubidoux Creek near the point of total streamflow loss apparently flows beneath the lower gaining reach of Roubidoux Creek and discharges at Roubidoux Spring. Dye-trace injection and recovery data for T103-06 are presented in tables 11 and 12 , at the back of this report. Relative fluorescence intensity of dye eluted from charcoal packets collected at Roubidoux Spring for 6 weeks after injection is shown in figure 13. 


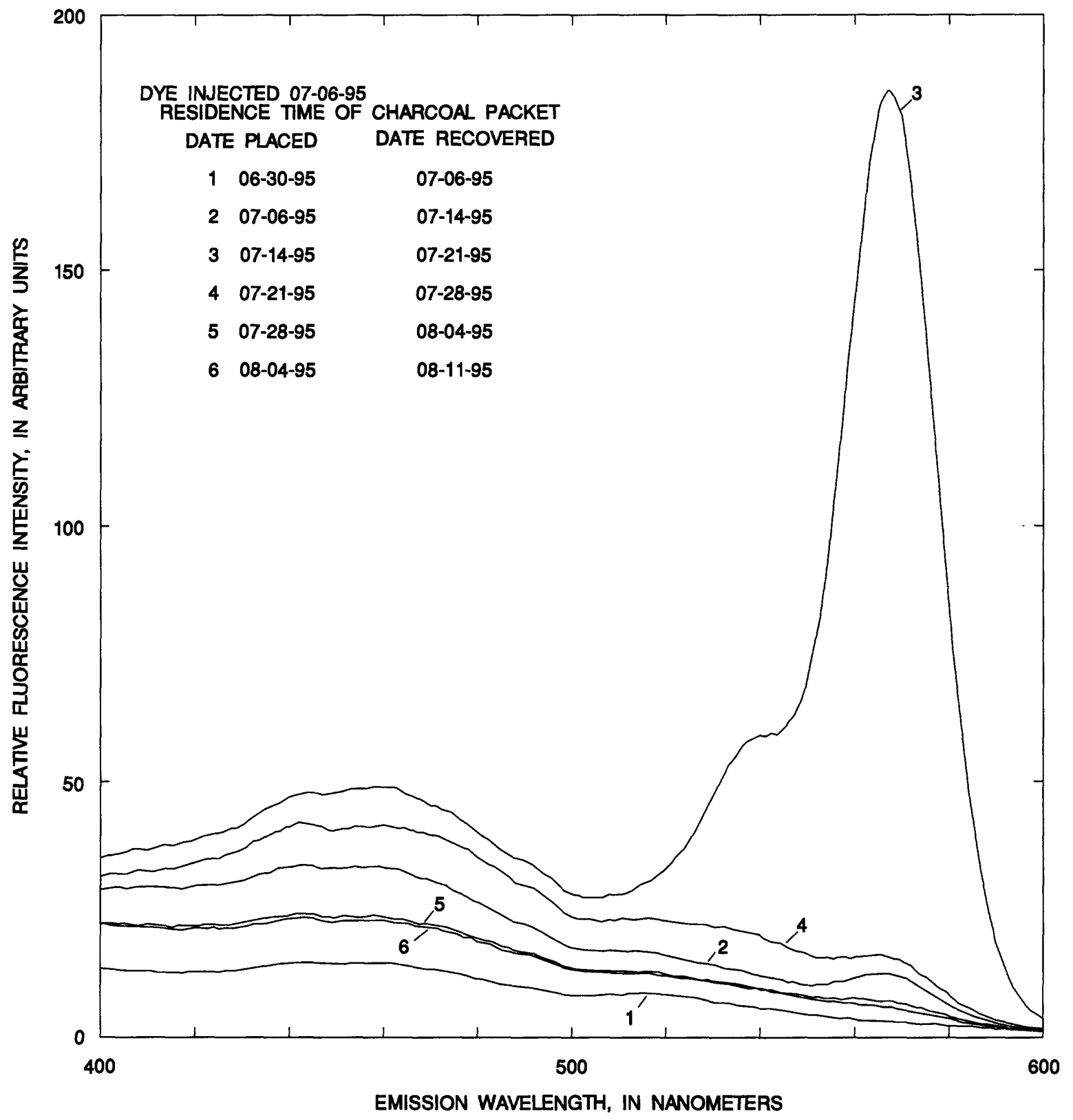

Fgure 13. Spectral analysis of fluorescent material extracted from activated charcoal packets placed in Roubidoux Spring during dye-trace test T103-06.

Dye-trace test T103-07 (fig. 7) began July 13, 1995, and was completed in September 1995. Fluorescein dye was used in this dye-trace test to maintain distinction from dye-trace test T103-06, which was in progress simultaneously. The dye was injected into a large sinkhole at the junction of roads FLW 24 and FLW 22 near the eastern edge of the cantonment area. A substantial pulse of dye was detected at the pumping station spring, located about $0.5 \mathrm{mi}$ north of the Big Piney River pumping station, between 1 and 8 days after injection. Background concentrations of fluores- cein dye were consistently detected at this recovery site during the course of the dye-trace test. The background fluorescein could be derived from residential areas $1 \mathrm{mi}$ west of the spring. However, the magnitude of the dye pulse detected after dye injection far exceeded the measured background concentrations. Substantial dye concentrations also were detected after the peak concentration, indicating that some water is flowing through alternate paths or temporarily is retained in storage. The ground-water flow rate along the path carrying the greatest dye load is less than $1 \mathrm{mi}$ 
per day. Also, about 1 to 8 days after injection, analyses of charcoal packets collected from Shanghai Spring indicated the presence of fluorescein dye. The dye concentration at Shanghai Spring (fig. 7) was substantial, but was not considered large enough to be clearly distinguished from fluctuating concentrations of background fluorescent material at the spring. This dye-trace test could be repeated with more dye injected or a different dye to confirm or deny a direct hydraulic connection between the injection point and Shanghai Spring. Dye-trace injection and recovery data for T103-07 are presented in tables 13, 14, and 15 , at the back of this report. Relative fluorescence intensity of dye eluted from charcoal packets collected at the pumping station spring is shown in figure 14; relative fluorescence intensity of dye eluted from charcoal packets collected at Shanghai Spring is shown in figure 15.

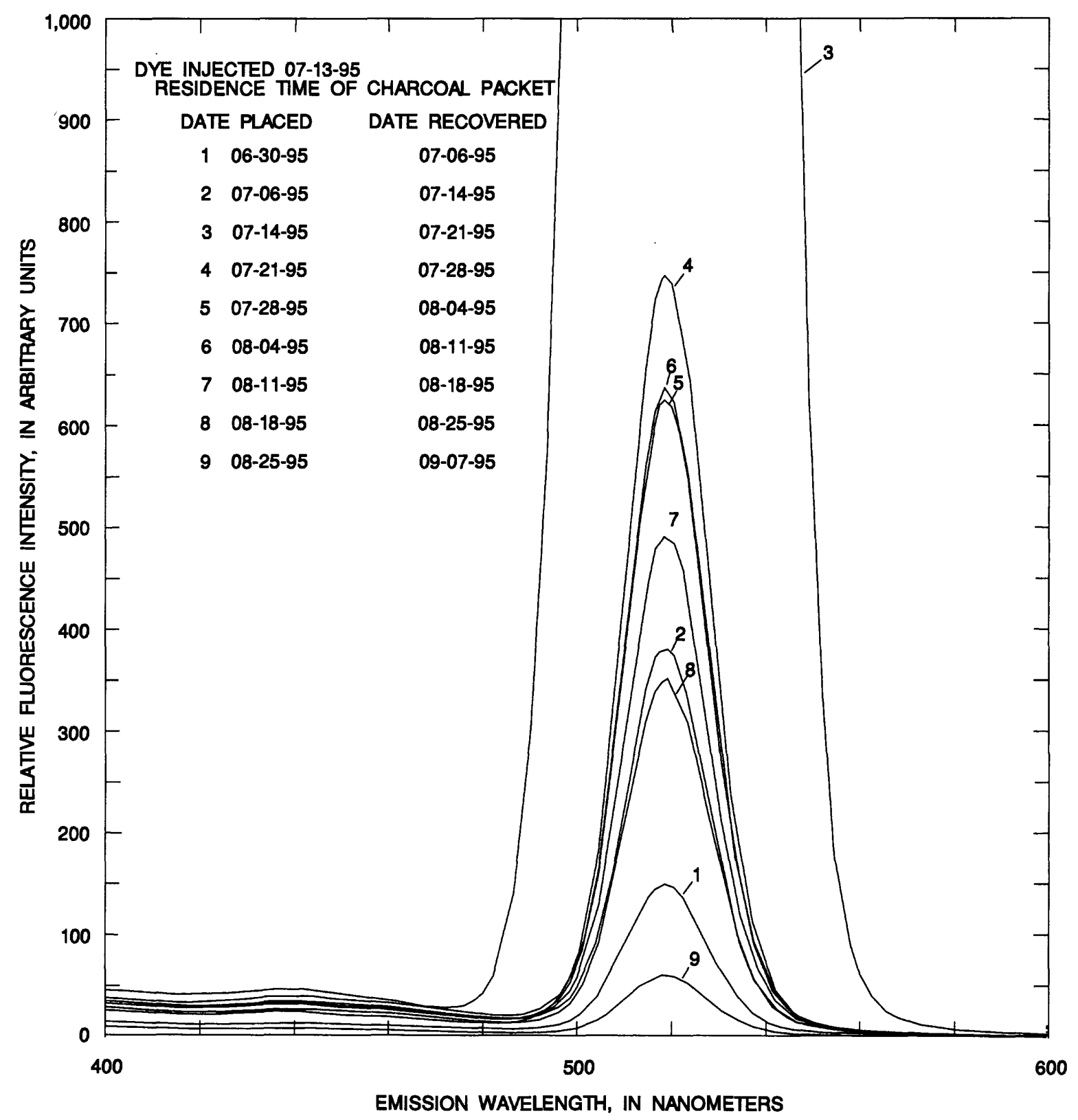

Figure 14. Spectral analysis of fluorescent material extrated from activated charcoal packets placed in the pumping station spring during dye-trace test T103-07. 


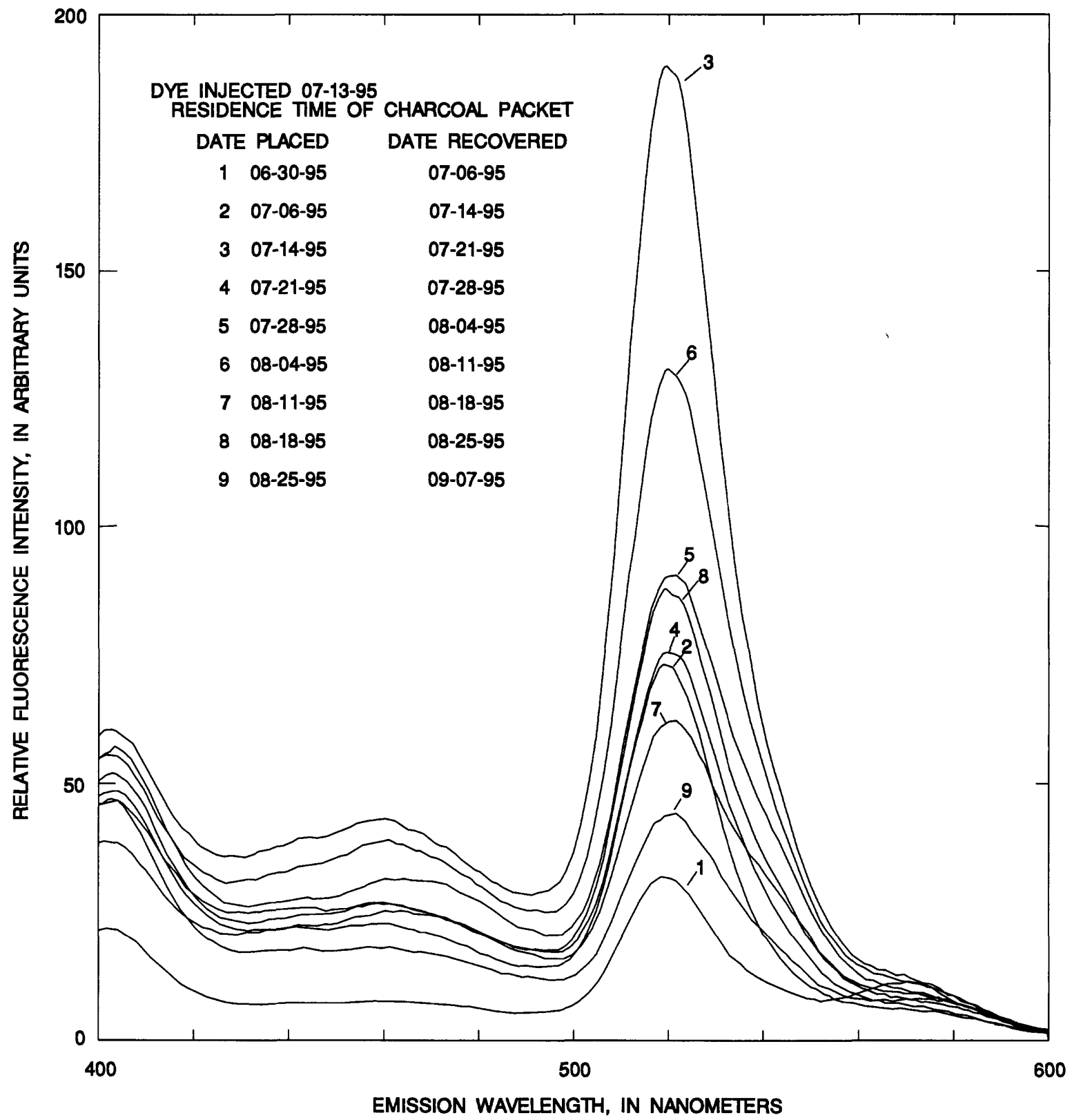

Fgure 15. Spectral analysis of fluorescent material extracted from activated charcoal packets placed in Shanghai Spring during dye-trace test T103-07.

Based on historical dye-trace investigations near the FLWMR, dye-trace tests conducted as part of this study, and ground-water-level measurements made during high- and low-base flow conditions, a map (fig. 16) was constructed showing the probable catchment areas of selected springs. The catchment area of the combined Falling Spring, Creasy Spring, and Bartlett Mill Spring drainage system is based entirely on historical dye traces, primarily conducted by the MDGLS near the Gasconade River (fig. 7). The eastern and southern boundaries of that area were drawn mostly based on ground-water divides as determined from mapped ground-water levels in figure 6, except that part of the southern boundary is drawn south of the divide to incorporate results of a dye-trace test in that area. The northwestern boundary is drawn coincident with a losing reach of the Gasconade River.

The probable catchment area of Shanghai Spring lies southwest of the spring. The western boundary of that catchment area was drawn to coincide with the regional ground-water divide that extends through the FLWMR (fig. 6). Other bound- 


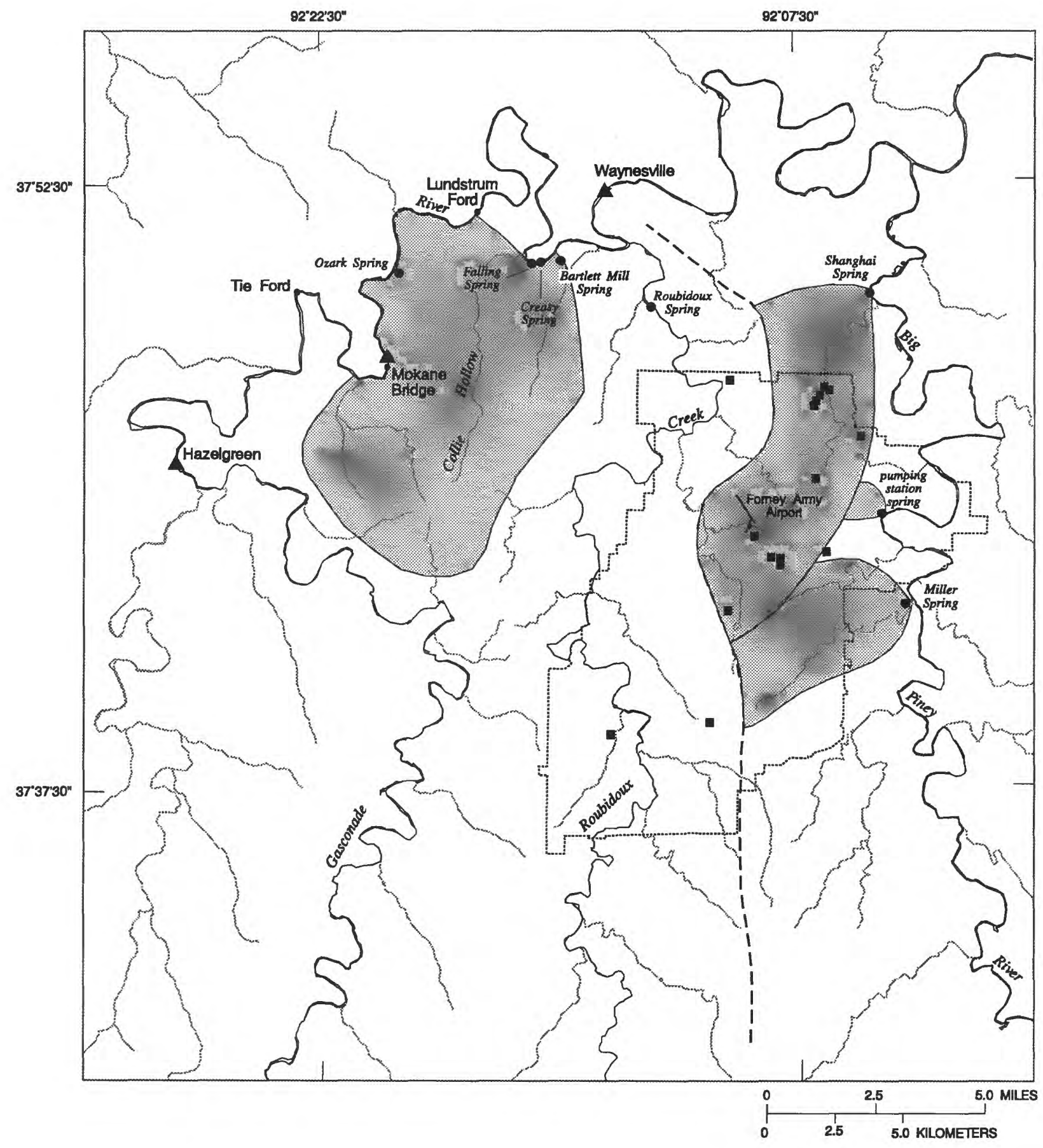

EXPLANATION

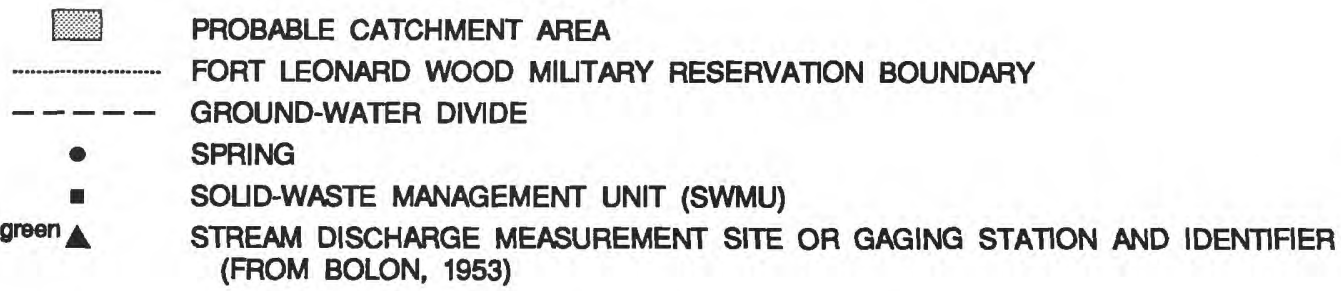

Figure 16. Probable catchment areas of selected major springs at and near the Fort Leonard Wood Military Reservation. 
aries were drawn to enclose dye-injection points known to transmit water to Shanghai Spring. The probable catchment area of the pumping station spring is based solely on the single dye-trace test to that spring and is assumed to share a common boundary with the catchment area of Shanghai Spring. The probable catchment area of Miller Spring extends west of the spring to the regional ground-water divide and is assumed to have a common boundary with the catchment area of Shanghai Spring. The remainder of that area is drawn to encompass dye-injection points known to transmit water to Miller Spring.

\section{SURFACE-WATER HYDROLOGY}

Surface-water drainage within the FLWMR is by small tributary streams and dry washes that direct water from a central topographic ridge that divides the eastern and western parts of the FLWMR. Drainage systems in the eastern one-half of the FLWMR discharge water into the Big Piney River, which flows northward near the eastern boundary of the FLWMR and discharges into the Gasconade River. Drainage systems in the western one-half of the FLWMR discharge water into Roubidoux Creek, which flows northward near the western boundary of the FLWMR and discharges water into the Gasconade River. Several large manmade ponds and lakes that have been built on the FLWMR are located in a 3-mi wide band that extends east-west across the FLWMR immediately south of Forney Army Airport. Most of these impoundments were constructed near the central dividing ridge in the headwater areas of small ephemeral streams. At least one lake was built over an active sinkhole that subsequently collapsed.

The Big Piney River and Roubidoux Creek are the two primary discharge areas for precipitation that percolates through the unsaturated zone and recharges the water table in the FLWMR. Previous seepage-run measurements, a series of stream discharge measurements made along a stream reach during a short time to identify where gains and losses in flow occur, were conducted on these streams and the Gasconade River northwest of the FLWMR. The measurements provided data on changes in the volumetric rate of streamflow along each stream channel. These flow-rate changes were used to estimate the magnitude and distribution of ground-water discharge to each stream and, thus, identify gaining and losing stream reaches to quantify the degree of ground- and surface-water interaction.

The USGS conducted a low-flow seepage run on the Big Piney River, September 17 and 18, 1953, and determined the recurrence interval of the measured streamflow. The recurrence interval is the average interval (in years) between occurrences of discharge less than that measured. The discharge was determined at six sites on the mainstem of the Big Piney River from where flow began in Texas County (about 10 mi south of the FLWMR) to its mouth in Pulaski County. The discharge of two tributary streams also was measured. The following streamflow discharge and recurrence intervals were determined upstream from Houston ( $25 \mathrm{mi}$ southeast of the FLWMR), $12 \mathrm{ft}^{3} / \mathrm{s}$ (cubic feet per second) discharge, 25-year recurrence interval; middle reaches (from Houston to Ross Bridge; fig. 17), $106 \mathrm{ft}^{3} / \mathrm{s}, 5$ years; and lower reaches (from Ross Bridge to mouth), 161 $\mathrm{ft}^{3} / \mathrm{s}, 2$ years (Skelton, 1976). The results of this seepage run indicate that the discharge generally increased downstream.

A seepage run also was conducted on the Roubidoux Creek by the USGS on July 13, 1971 (Skelton, 1976, fig. 7). The discharge was determined at 10 sites along the mainstem of Roubidoux Creek from its headwaters in Texas County to its mouth in Pulaski County. The three measurements made on Roubidoux Creek mainstem in Texas County show the discharge increases downstream, the entire flow of the creek is lost in Pulaski County, and flow begins again in the lower reach of the creek in the northern part of the FLWMR (fig. 6). The recurrence interval for the 10 $\mathrm{ft}^{3} / \mathrm{s}$ discharge measured near the mouth of Roubidoux Creek was determined to be 2 years.

During September 17 and 18, 1953, a low-flow seepage run was conducted by the USGS on the Gasconade River between the USGS gaging stations at Hazelgreen and Waynesville (fig. 16; Bolon, 1953). The most downstream part of this reach receives water from springs that collect water from a catchment area northwest of the FLWMR (fig. 16). The seepage-run data indicated that flow diminished from 32.2 to 3.9 $\mathrm{ft}^{3} / \mathrm{s}$ between Tie Ford and Lundstrum Ford, with most of the flow being lost between Mokane Bridge and Ozark Spring (Bolon, 1953). Substantial flow was observed entering a sinkhole at the west side of the Gasconade River immediately north of the bridge approach at Ozark Spring. Additional measurements made at a later date indicate the river consistently 


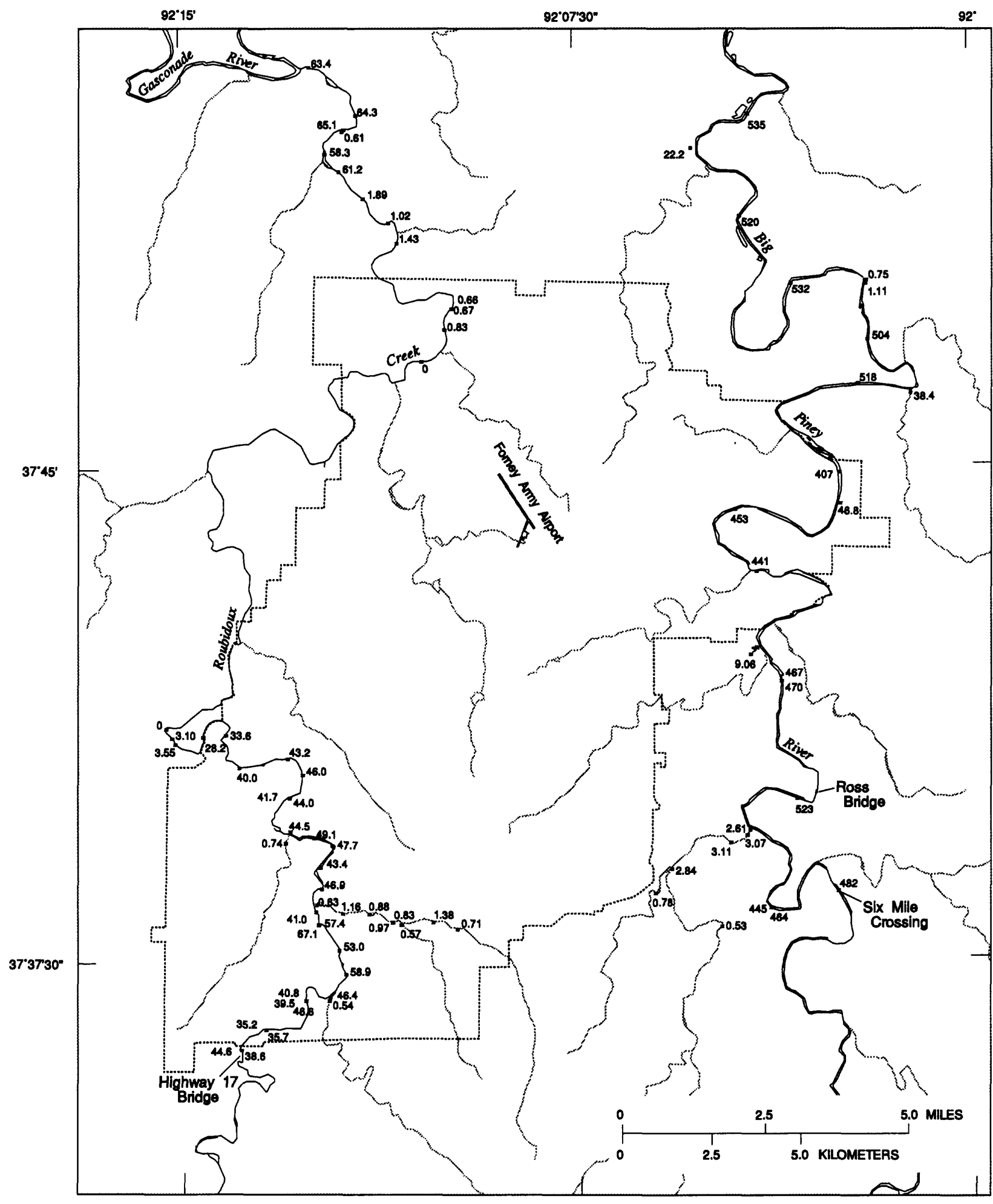

EXPLANATION

FORT LEONARD WOOD MILTARY RESERVATION BOUNDARY

.36.8 STREAM DISCHARGE MEASUREMENT--Number is flow rate, in cubic feet per second. Selected tributary discharge measurements larger than 0.05 cubic foot per second are shown

Fgure 17. Stream discharge measurements for the high-base flow seepage run made on the Big Piney Rlver, Roubidoux Creek, and selected small tributary streams in December 1994 at and near the Fort Loonard Wood Military Reservation. 
loses flow (from 18 to $30 \mathrm{ft}^{3} / \mathrm{s}$ ) in this reach, regardless of river stage. Other measurements made during the 1953 seepage run indicated that within the reach of the Gasconade River between the mouth of Collie Hollow to and including Bartlett Mill Spring (0.75 river mi reach) the flow increased in the Gasconade River from 4.3 to $69.8 \mathrm{ft}^{3} / \mathrm{s}$. Most of this increase in flow was observed boiling up through the gravel in the streambed and adjacent to the channel. Flow also was contributed by Creasy, Falling, and Bartlett Mill Springs and from other unnamed springs. The temperature of the water from the gravel boils was about $5^{\circ} \mathrm{F}$ warmer than the water from the other springs, indicating that the water from the gravel boils had not traveled sufficiently underground to assume low groundwater temperatures (Bolon, 1953).

Three sets of seepage-run measurements were conducted on the Big Piney River, and two sets of seepage-run measurements were conducted on Roubidoux Creek during this investigation. The first two seepage runs on the Big Piney River were made during high-base flow conditions and the third during lowbase flow conditions. The first Roubidoux Creek seepage run was made during high-base flow conditions; the second was during low-base flow conditions. Measurements made during high-base and low-base flow conditions are necessary to assess seasonal variations in the magnitude of ground-water discharge to streams. Continual stream-stage data were also collected at a gaging station on the Big Piney River at Ross Bridge (fig. 17).

Springs are present along the Big Piney River near the eastern border of the FLWMR (fig. 3) and, to a much lesser extent, along Roubidoux Creek near the western border of the FLWMR. Some of the larger springs are Shanghai Spring, Ousley Spring, Stone Mill Spring, and Miller Spring in the Big Piney River Basin and Roubidoux Spring in the Roubidoux Creek Basin. Several smaller perennial and wet-weather springs discharge from solution-enlarged bedrock contacts and fractures throughout the FLWMR. Discharge rates of many of these springs were measured as part of the seepage-run measurements.

\section{Methodology}

Generally, seepage runs are designed to be made during periods of minimum streamflow and minimal daily streamflow fluctuations (base flow periods). During these periods, streams are sustained by ground water and spring discharge, not by surface runoff. These base flow periods typically occur in late summer or fall. However, a seepage run made in the winter or spring when base flows are larger (high-base flow) can supply valuable information in stream reaches of extreme water loss, such as Roubidoux Creek. The series of discharge measurements in the seepage run normally is designed to be made in consecutive downstream order. During both seepage runs on Roubidoux Creek, this procedure could not be used because of accessibility restrictions. Where a firing range overlapped a part of Roubidoux Creek, access to that part of Roubidoux Creek was denied when that range was being used on a particular day. This interruption in the normal procedure caused data gaps along selected stream reaches that were filled as the stream reach could be accessed.

During the seepage-run measurements, access to measuring sections on the Big Piney River was primarily gained by boat; access to sections on Roubidoux Creek was by wading. Wading measurements were made at selected locations along both streams and at the mouths of inflowing tributaries. Seepagerun measurements were made at locations where stream channel morphology and velocity were conducive to accurate discharge measurements. Discharge was measured using either a standard AA or pygmy current meter, depending on stream velocity and depth. The methods used to make discharge measurements and the criteria used to determine the type of current meter applicable to the measuring section are described by Rantz and others (1982). The accuracy of the measurements were rated according to stream channel conditions and uniformity of flow. The rated measurement accuracy is subjective and defined as follows: "good" means that the actual discharge is thought to be within 5 percent of the measured discharge, "fair" is 5 to 8 percent; and "poor" is more than 8 percent. Where channel conditions were not adequate for making discharge measurements, either because of insufficient depths or small flow velocities, discharge was estimated. However, all measurements were not given a rating. The error at the sites where flow is estimated may exceed 8 percent.

Generally, check measurements were made each day at one or more of the measuring sections. This check measurement consisted of a streamflow measurement made by two different people at the same measuring section and was used as a quality-control procedure. The two measurements were expected to be 
within the degree of accuracy defined by the rated measuring conditions.

Specific conductance and temperature of the water were typically measured at the discharge measurement site. Specific conductance values were measured using a portable conductivity meter with temperature compensation designed to read in microsiemens per centimeter at $25^{\circ} \mathrm{C}$ (degrees Celsius). Water temperature was measured with a thermistor to the nearest $0.1^{\circ} \mathrm{C}$.

During the winter and spring when high-base flow conditions occur, sustained periods of no precipitation rarely occur. For this reason, the seepage runs were started after precipitation had occurred and sufficient time had elapsed for small tributary streams to stop flowing. However, the Big Piney River and Roubidoux Creek still had substantial variations in daily streamflow during the December 1994 and February 1995 high-base flow seepage runs. These conditions probably showed more variability than a normal base flow period; however, the series of discharge measurements were made, and collectively they will be referred to as high-base flow seepage runs.

To establish the daily flow rate variation, a policy was established that the last section measured each day would be the first section measured at the beginning of the following day. This procedure was not followed during the December 1994 seepage run on the Big Piney River. Because of this fact and quality-control concerns, a second high-base flow seepage run was conducted on the river in February 1995.

During the data analysis of these seepage runs, adjustments were made to the measured discharge along the mainstem of both the Big Piney River and Roubidoux Creek. The first adjustment removed the quantity of flow contributed to the mainstem of the stream by tributaries and springs. This "inflow adjustment" was made to each discharge measurement on the mainstem by first calculating the cumulative discharge of all tributaries and springs that entered the mainstem upstream of the site where the discharge measurement was made. The cumulative total from tributary and spring inflow was then subtracted from the discharge measurement. This adjustment was made to remove the increase in flow along the mainstem from sources that were visibly contributing water. Therefore, any net increase in discharge along the stream reach after this adjustment was applied would be a result of the diffuse ground-water inflow along the streambed and not surface water or spring inflow.

A second adjustment, hereafter referred to as the "common-base adjustment," was made to the measured discharges along the mainstem of both the Big Piney River and Roubidoux Creek during the three high-base flow seepage runs. The common-base adjustment was applied primarily to remove some of the substantial daily flow rate variation that was occurring in these streams during the high-base flow conditions. This adjustment involved applying a shift to each set of daily discharge measurements, so that discharge measurements made on consecutive days could be brought to a common base. Each set of discharge measurements consists of all the mainstem discharge measurements made on a specific day. The applied shift was determined by the difference in the consecutive discharge measurements that were made at the same measuring section at the end of the day and at the start of the following day. For example, rainfall on February 14 and 15 caused the discharge measured at river mile 23.68 to change from $408 \mathrm{ft}^{3} / \mathrm{s}$ on February 14 to $501 \mathrm{ft}^{3} / \mathrm{s}$ when the interrupted seepage run was restarted on February 17. Because flow in the stream increased $93 \mathrm{ft}^{3} / \mathrm{s}$ from propagation of water from areas upstream of the FLWMR, this amount was subtracted from all the measurements made on February 17 to bring those measurements to the same base as measurements made previously.

The procedure of measuring the discharge at the same section at the end of the day and again at the start of the following day was not followed during the December 1994 seepage run on the Big Piney River. Therefore, the applied common-base adjustment was determined using the difference in daily mean discharge as recorded at the gaging station at Ross Bridge. The decrease in daily mean flow in the Big Piney River was determined to be $88 \mathrm{ft}^{3} / \mathrm{s}$ at the gaging station for the period during the seepage run. This variation was prorated and then subtracted from the discharge measurements made on each corresponding day. This correction considerably reduced the fluctuation of the measurements; however, the data scatter was still large compared to the small variations expected from ground-water inflow. 


\section{High-Base Flow Stream and Spring Discharge}

The first high-base flow seepage run (table 16, at the back of this report; fig. 17) on the mainstem of the Big Piney River was made during December 12 to 14, 1994. Between November 21 and December 8 , $1994,0.23$ in. of rainfall was recorded at Waynesville (fig. 18); on December 9, 1994, 0.21 in. of rainfall was recorded (National Oceanic and Atmospheric Administration, 1994). Runoff and increased ground-water inflow to streams and springs caused river conditions to change 2 days before the scheduled start of the seepage run; however, measurements were continued as scheduled. Discharge was measured at 16 locations in the mainstem of the Big Piney River along a 38river mi reach from an access locally known as Six Mile Crossing to the mouth of the river. A substantial part of this river reach borders or is interior to the FLWMR. Discharge also was measured or estimated at the mouths of 81 stream and spring tributaries of Big Piney River (58 of which had no flow). Four springs (Shanghai Spring, Ousley Spring, Stone Mill Spring, and Miller Spring) with substantial flow were identified, and their discharge was measured. Four tributary streams that drain the FLWMR were investigated in more detail. Discharge measurements were made in these four streams from the stream mouths at Big Piney River to the point where flow began in the headwater areas.

Because of substantial daily streamflow fluctuations and procedural and quality-control concerns during the first seepage run, a second high-base flow seepage run was conducted on the Big Piney River between February 13 to 22, 1995 (table 17, at the back of this report; fig. 18). During the interval from the planning stage to the start of this second seepage run, streamflow and climatological conditions were favorable. However, between February 14 and 15, 1995, a total of $0.30 \mathrm{in}$. of rainfall was recorded at the

FLWMR. The remainder of the seepage run was postponed on February 15, 1995, and began again on February 17,1995 . Because daily streamflow fluctuations were still considered to be extreme, further work was postponed until February 20. During this seepage run the same 38-river mi reach of Big Piney River was measured as in the first seepage run. During this seepage run, 31 discharge measurements were made at 22 locations on the mainstem of Big Piney River. Discharge also was determined at the mouths of 41 stream and spring tributaries (15 of which had no flow).
A high-base flow seepage run (table 16; fig. 17) also was made on Roubidoux Creek from December 12 to 14,1994 . Discharge was determined at 58 locations ( 16 of which had no flow) along a 34 river mi reach of Roubidoux Creek from the Missouri Highway 17 bridge to the mouth. Flow also was determined at the mouth of 40 stream and spring tributaries of Roubidoux Creek (27 of which had no flow). A reach of Roubidoux Creek from the Missouri Highway 17 bridge to 2 river mi downstream was remeasured on December 15, 1994, because the percentage of difference between check measurements made along this reach during the seepage run were outside acceptable limits. These seepage-run data also were analyzed to determine the diffuse ground-water inflow component by applying the inflow adjustment, and the commonbase adjustment was applied to adjust the measurements of each succeeding day. The common-base adjustment primarily corrected the data for small flow changes caused by propagation of water from areas upstream of the FLWMR and the small differences caused by different individuals measuring separate reaches of the same stream.

\section{Low-Base Flow Stream and Spring Discharge}

Stream discharge measurements (table 18, at the back of this report; fig. 19) also were made on the same 38-river mi reach of the Big Piney River during low-base flow conditions from September 18 to 25, 1995. Although rainfall occurred before the start of and during the seepage run, antecedent conditions were excessively dry and there was little runoff. Streamflow fluctuations were minimal during this seepage run even though 0.66 in. of rainfall was recorded at the FLWMR on September 19, 1995. The river reach measured on September 19 was reexamined the next day to verify that effects of the rainfall on streamflow were minimal. Twenty-five low-flow discharge measurements were made on the Big Piney River mainstem at 19 locations. Discharge also was determined at the mouth of 57 stream and spring tributaries ( 35 of which had no flow). Because of the sustained dry weather before the measurements and the minimal effect of the September 19th rainfall, the only adjustments made to this streamflow data were the subtraction of tributary inflows from mainstem measurements (inflow adjustment). 


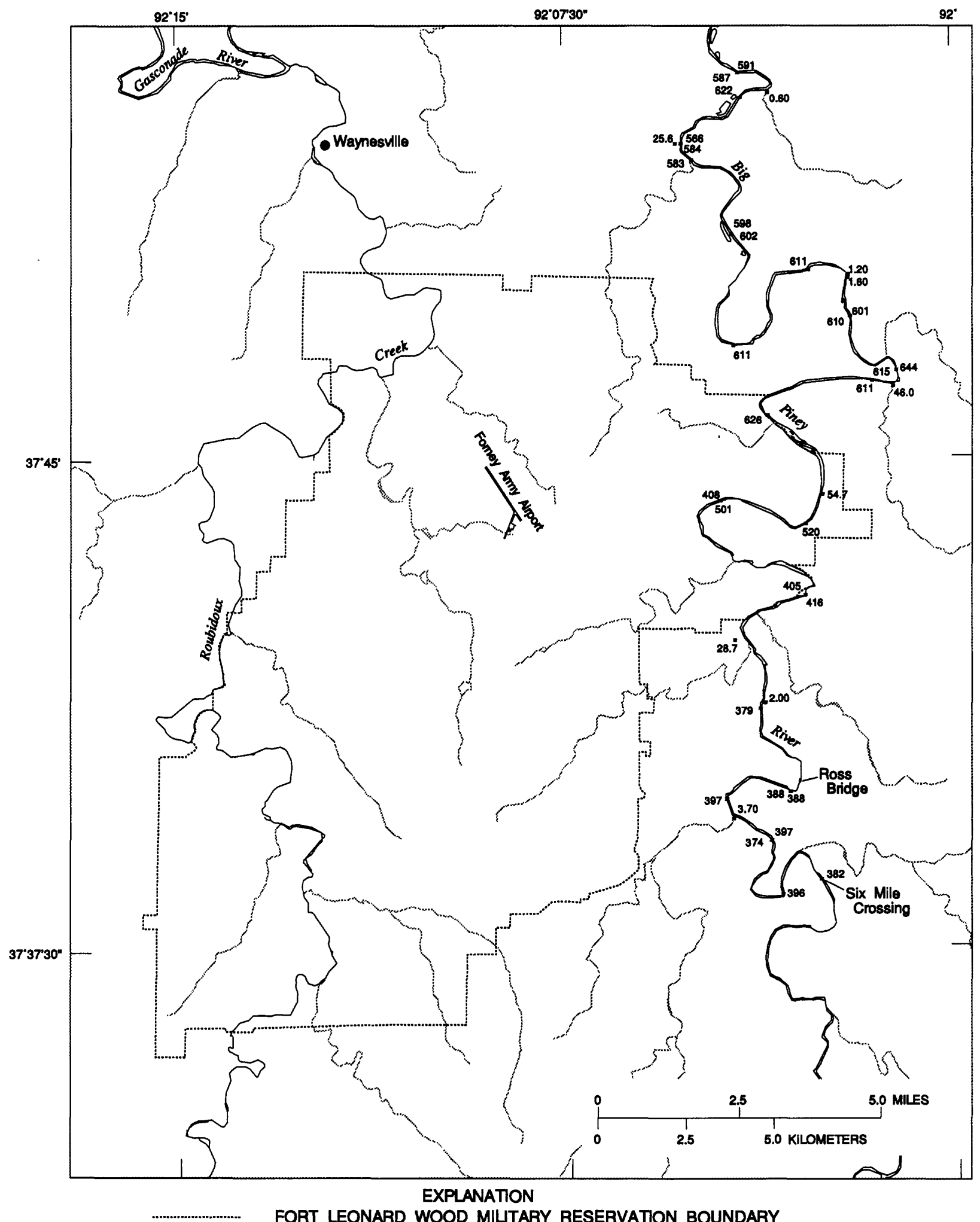

382 STREAM DISCHARGE MEASUREMENT--Number is flow rate, in cubic feet per second. Selected tributary discharge measurements larger than 0.05 cubic foot per second are shown

Fgure 18. Stream dischange measurements for the high-base flow seepage run made on the Big Piney River in February 1995 at and near the Fort Leonard Wood Military Reservation. 


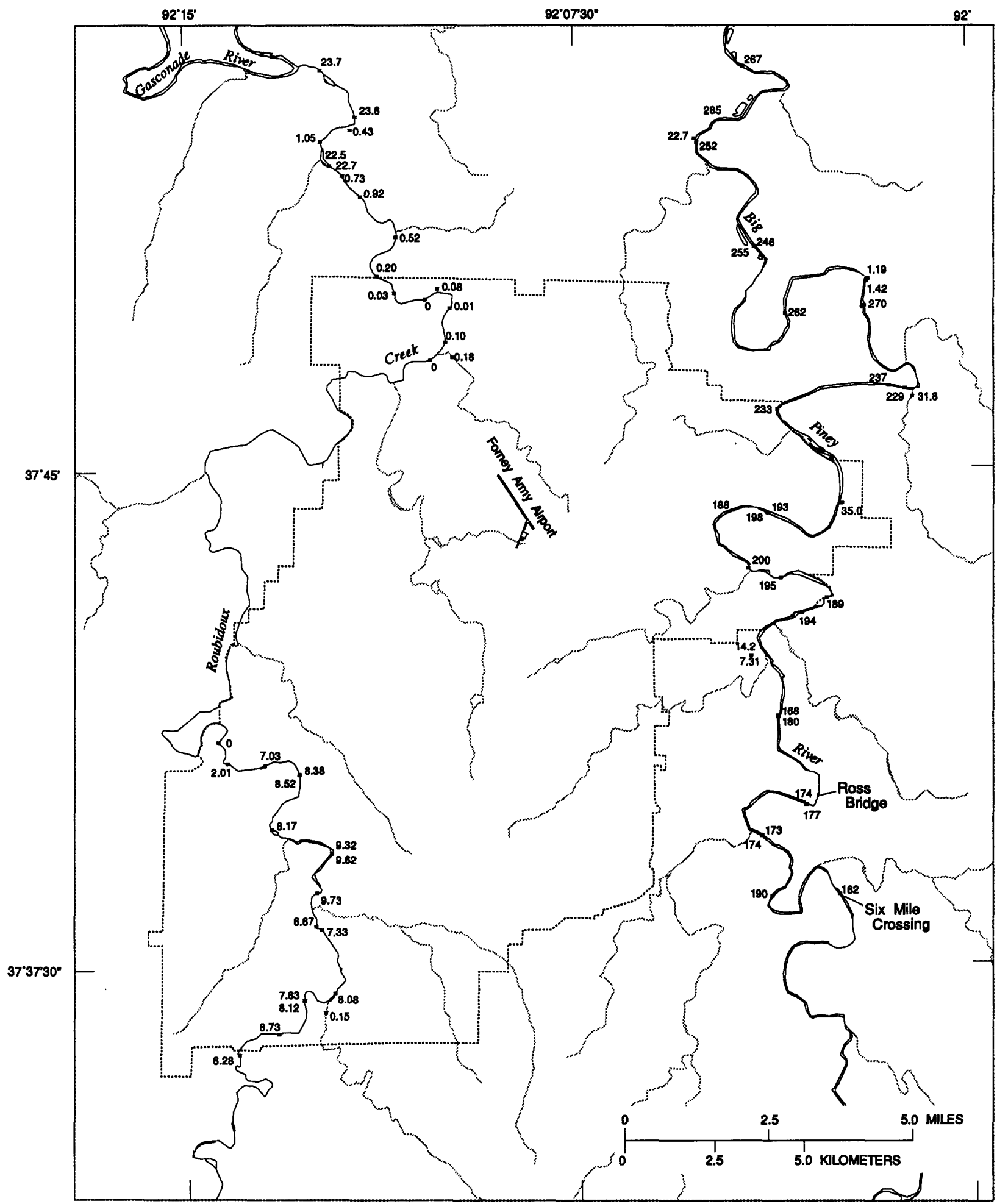

EXPLANATION

FORT LEONARD WOOD MILTTARY RESERVATION BOUNDARY

STREAM DISCHARGE MEASUREMENT--Number is flow rate, in cubic feet per second. Selected tributary discharge measurements larger than 0.05 cubic foot per second are shown

Fgure 19. Stream discharge measurements for the low-base flow seepage run made on the Big Piney River, Roubidoux Creek, and selected small tributary streams in September 1995 at and near the Fort Leonard Wood Military Reservation. 
A low-flow seepage run was conducted on Roubidoux Creek from September 5 to 13, 1995, along the same 34 river mi reach that was investigated during the high-base flow seepage run (table 18; fig. 19). Twenty-nine discharge measurements were made ( 3 with no flow) at 25 different locations. Discharge also was determined at the mouth of 24 stream and spring tributaries (15 of which had no flow). Only the inflow adjustment was required to analyze this seepage-run data, considering the lack of rainfall before and during the measurements.

\section{Ground-Water Discharge to Streams}

The result of the seepage runs indicates a substantial increase in stream discharge in the mainstem of the Big Piney River from Six Mile Crossing to the mouth of the river. Much of this increased flow was caused by the inflow of tributaries and springs. To differentiate between the amount of flow contributed by inflow from tributaries and springs and that contributed by diffuse ground-water inflow, the inflow adjustment was applied. The result represents the effects of surface- and ground-water interaction. The adjusted discharge data were plotted as a function of the location of the measurement from the mouth of the stream (fig. 20).

Analyses of the general trend of stream discharge data collected on the Big Piney River during February 1995 at high-base flow and September 1995 at low-base flow (fig. 20) indicate that the river, with respect to the ground-water system, loses water from about 30 to 38 river mi upstream from the mouth, gains water from about 18 to 30 river mi upstream from the mouth, and loses water from about 18 river mi upstream from the mouth to near the mouth. All data was adjusted for tributary and spring inflow and the high-base flow data collected in December 1994 and February 1995 was adjusted for daily flow rate variation. However, the large uncertainty in the streamflow measurements (estimated at 5 to about 10 percent) and the relatively small magnitude of flow changes caused by surface- and ground-water interaction makes it difficult to state any conclusion with certainty. The December 1994 adjusted data contain too much scatter to provide even a qualitative estimate of the location of losing or gaining stream reaches.

An analysis of stream discharge data collected on Roubidoux Creek during high- and low-base flow conditions as adjusted for tributary and spring inflow and adjusted to a common base during high-base flow conditions (fig. 20) indicates Roubidoux Creek to be a markedly different type of stream from the Big Piney River. Stream discharge measurements indicate that Roubidoux Creek gains water through its streambed from 28 to about 34 river mi upstream from the mouth. During high-base flow conditions, the entire flow of Roubidoux Creek is lost from about 22 to about 28 river mi upstream from the mouth, with most of the loss occurring within about a 1-mi reach. During lowbase flow conditions, the entire flow is lost 24 river mi upstream from the mouth, or about 2 river mi upstream from the point of flow loss during high-base flow conditions. This flow loss occurs at and is associated with the intersection of Roubidoux Creek, the Countyline Fault, and Hurd Hollow Fault (Harrison and others, 1996; fig. 3). Hurd Hollow Fault also crosses Hurd Hollow near where Hurd Hollow Stream loses its entire flow. Measurements made on the lower reach of Roubidoux Creek (from 1 to 8 river mi upstream from the mouth) indicate that essentially all flow in this reach of the creek is derived from tributary or spring inflow.

During all but the highest flow conditions caused by large amounts of runoff, Roubidoux Creek is dry throughout the nearly 7 to 8 river mi reach identified by shading on figures 5 and 6. Ground-water levels along this reach of Roubidoux Creek typically are 20 to $30 \mathrm{ft}$ below the streambed, and the creek is a subterranean trough-shaped feature in the water-table surface. Part of the explanation for this situation is that, in this reach, the Roubidoux Creek stream channel contains thick gravel deposits and may be controlled by large hydraulically connected fractures. Although some ground water does flow toward Roubidoux Creek from the central part of the FLWMR along this reach (fig. 5), the diversion of large quantities of ground water from the Roubidoux Creek Basin to the Big Piney River by karst features substantially decreases available ground-water discharge and, therefore, streamflow in Roubidoux Creek. Flow in Roubidoux Creek resumes about 2 river mi before the stream channel crosses the northern boundary of the FLWMR.

\section{WATER QUALITY}

Water-quality samples were collected from selected domestic and public-supply wells, springs, the Big Piney River, Roubidoux Creek, and selected 

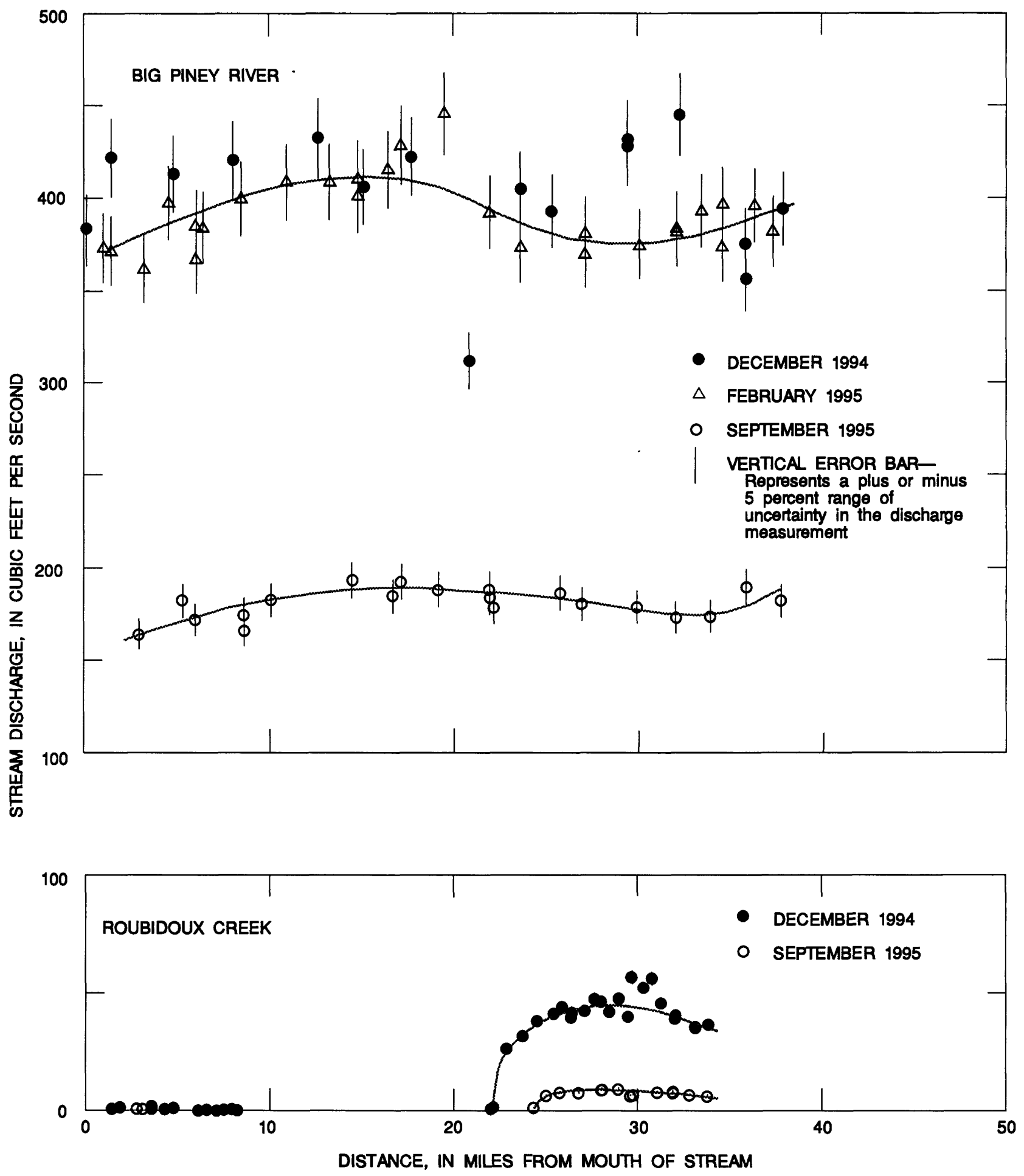

Figure 20. Variations in stream discharge (corrected for tributary and spring inflow and for daily flow rate variation) along the Big Piney River and Roubidoux Creek. 
tributaries draining the FLWMR to determine baseline water-quality conditions. Sample locations generally were chosen to represent regional water sources and not effects from any specific source area or site. Depending on the location, water samples were analyzed for a comprehensive suite of inorganic and organic constituents, including dissolved and total major cations, anions, and trace elements, total cyanide $\left(\mathrm{CN}_{t}\right)$, nutrients, total organic carbon (TOC), a suite of 73 VOCs, semivolatile organic compounds or semivolatile organic compound scan by gas chromatography with flame ionization detection (GC-FID), selected pesticides, chlorophenoxy-acid herbicides, and XACs. Streambed sediment samples were analyzed for grain size, concentrations of major and trace inorganic constituents, chlorophenoxy-acid herbicides, chlorinated organic compounds, XACs, and dioxins and furans. Concentrations of major and trace inorganic constituents generally refer to the dissolved phase unless noted otherwise.

\section{Methodology}

Water-quality samples were collected using modifications of standard USGS methods (Guy and Norman, 1970; Wood, 1976; Shelton, 1994). Water samples from domestic and public-supply wells were collected from the tap nearest the wellhead. Interviews with domestic well owners were conducted to determine the location of water softeners or pressure tanks and recent water use. All wells were purged to remove stagnant water in the well bore, pump, and pipes before sampling. Domestic wells were purged by allowing water to flow freely for a minimum of 30 minutes. Public-supply wells were sampled by allowing the pump to run for a minimum of 20 minutes. During purging, specific conductance, $\mathrm{pH}$, and water temperature were monitored in a closed beaker; waterquality samples were not collected until these measurements had stabilized. Stabilization criteria generally were as follows: specific conductance (successive measurements within 2 percent), $\mathrm{pH}$ (successive measurements within $0.02 \mathrm{pH}$ unit), and temperature (successive measurements within $0.5^{\circ} \mathrm{C}$ ). Samples for analyses of total inorganic and organic constituents were collected in plastic or baked-glass bottles directly from the tap. Samples for the determination of VOCs were collected in $40 \mathrm{~mL}$ (milliliter) amber glass vials fitted with a Teflon-lined septum cap.
All sample preservation and filtering was done at the site immediately after sample collection. Samples for dissolved inorganic constituent analyses were filtered through a $0.45 \mu \mathrm{m}$ (micrometer) nominal poresize disposable capsule filter using a peristaltic pump as the pressure source. Samples for the determination of dissolved organic constituents were filtered using a 142-mm (millimeter) diameter $1.0 \mu \mathrm{m}$ pore-size baked glass fiber filter placed in an aluminum filter holder. A fluid metering pump was used as the pressure source. Corrugated Teflon tubing was used to attach the pump to the filter assembly.

Depth-integrated water samples were collected from the Big Piney River, Roubidoux Creek, Miller Spring, Shanghai Spring, and Roubidoux Spring using a hand-held USGS DH-81 isokinetic Teflon sampler according to the methods described in Edwards and Glysson (1988) and Ward and Hair (1990). A minimum of 10 individual subsamples were collected at equal widths across the stream. Subsamples were composited in 3-L Teflon containers. Samples for analyses of VOCs were collected directly from the spring or stream by filling and capping the bottles beneath the water surface near the center of flow.

Determinations of specific conductance, $\mathrm{pH}$, temperature, dissolved oxygen concentration, and total alkalinity were made at the sampling site. Specific conductance, temperature, and concentrations of dissolved oxygen were determined using portable meters and placing probes near the center of flow. The $\mathrm{pH}$ was measured by immersing the $\mathrm{pH}$ probe in a closed beaker containing water collected from the subsample nearest the center of flow. Samples from smaller springs and tributaries were collected by filling sample bottles or compositing containers directly from the center of flow.

All water-quality, sediment-sampling, and support equipment (for example, compositing containers, churn splitter, cone splitter, peristaltic pump hose, and pump hoses) were thoroughly cleaned before initial use and between each onsite use. The general cleaning protocol included an initial rinse with a non-phosphate detergent, followed by successive rinses in tap water, dilute acid, deionized water, methanol (organic-compound sampling only), and organic-free deionized water (organic-compound sampling only). In addition, samplers, pumps, and hoses were pre-rinsed with ambient water before sample collection and processing. The effectiveness of the cleaning procedures was monitored by the use of routine equipment blanks. In 
addition to equipment blanks, a number of VOC trip blanks (containing organic-free deionized water) were carried to the sampling sites, preserved, and shipped in sample coolers to verify contaminants were not introduced into VOC samples during sample handling or storage.

The specific conductance of water samples was measured using a portable conductance meter with temperature compensation designed to express values in microsiemens per centimeter at $25^{\circ} \mathrm{C}$. The meter was calibrated before each measurement using standards prepared by the USGS water-quality laboratory in Ocala, Florida. Temperature was measured to the nearest $0.1{ }^{\circ} \mathrm{C}$ using a thermistor attached to the conductance meter. The $\mathrm{pH}$ was measured using a portable $\mathrm{pH}$ meter calibrated with standard buffers bracketing the expected sample $\mathrm{pH}$ before each measurement. Dissolved oxygen concentrations were determined using a portable dissolved oxygen meter. Alkalinity was determined by using incremental titration of 0.16 normal $(\mathrm{N})$ standardized sulfuric acid to $25 \mathrm{~mL}$ of sample past the carbonate-bicarbonate inflection point (approximately $\mathrm{pH} 8.3$ ) and the bicarbonate-carbonic acid inflection point (approximately $\mathrm{pH} 4.5)$. Concentrations of carbonate $\left(\mathrm{CO}_{3}\right)$, bicarbonate $\left(\mathrm{HCO}_{3}\right)$, and $\mathrm{CO}_{3}$ alkalinity were later computed using a computer program to integrate the rate of $\mathrm{pH}$ change to the equivalence of acid added.

To reduce or prevent the loss of ions or organic compounds from water samples, a variety of sample preservation treatments were used. When possible, filtering and adding chemical treatments to environmental samples was done inside a water-quality van to reduce the potential for contamination by airborne particulates. Samples to be analyzed for dissolved or total major cations and trace elements were acidified to a $\mathrm{pH}$ less than 2 using concentrated trace-metal-grade nitric acid $\left(\mathrm{HNO}_{3}\right)$. Samples for the determination of $\mathrm{CN}_{\mathrm{t}}$ were preserved using $10 \mathrm{M}$ (molar) sodium hydroxide to a $\mathrm{pH}$ greater than 10 and chilled to $4{ }^{\circ} \mathrm{C}$. $\mathrm{A} \mathrm{HNO}_{3}$-potassium dichromate solution was used to preserve samples for the analyses of total mercury $\left(\mathrm{Hg}_{\mathrm{t}}\right)$. Samples for nutrient analysis were acidified to a $\mathrm{pH}$ less than 2 using concentrated sulfuric acid $\left(\mathrm{H}_{2} \mathrm{SO}_{4}\right)$ and chilled to $4{ }^{\circ} \mathrm{C}$. A total of four vials were filled for each VOC sample; two vials were preserved with organic-free hydrochloric acid $(\mathrm{HCl})$ and two vials were unacidified. All VOC vials were placed in a dedicated cooler and chilled to $4{ }^{\circ} \mathrm{C}$. Samples for laboratory analysis or scan by GC-FID of semivolatile organic compounds were chilled to $4{ }^{\circ} \mathrm{C}$. Pesticide samples were filtered onsite and chilled to $4{ }^{\circ} \mathrm{C}$ for transport to the USGS laboratory in Rolla, Missouri, where they were extracted using a C-18 extraction cartridge. The cartridges were chilled and shipped to the USGS water-quality laboratory in Arvada, Colorado, where they were reextracted and analyzed. Samples for the determination of XACs were placed in bakedglass bottles and chilled to $4{ }^{\circ} \mathrm{C}$ for transport to the laboratory. Between 30 and 50 subsamples were collected from the top $2 \mathrm{~cm}$ (centimeters) of the streambed sediment in a stainless steel container for compositing. Subsamples for grain size and analysis of inorganic constituents were placed in sealed ziplock bags. Subsamples for the determination of organic compounds were placed in baked wide-mouth glass jars and chilled to $4^{\circ} \mathrm{C}$. All samples were shipped overnight and analyzed within guidelines established in the Sampling and Analysis Plan on file at the USGS in Rolla, Missouri.

Concentrations of most dissolved major cations and trace elements, except sodium $(\mathrm{Na})$, total sodium $\left(\mathrm{Na}_{\mathrm{t}}\right)$, potassium $(\mathrm{K})$, total antimony $\left(\mathrm{Sb}_{\mathrm{t}}\right)$, total arsenic $\left(\mathrm{As}_{\mathrm{t}}\right), \mathrm{Hg}_{\mathrm{t}}$, total selenium $\left(\mathrm{Se}_{\mathfrak{t}}\right)$, and total thallium $\left(\mathrm{Tl}_{t}\right)$, in water samples were determined by using inductively coupled liquid plasma (ICP). Concentrations of $\mathrm{Na}, \mathrm{Na}_{\mathrm{t}}$, and $\mathrm{K}$ were measured using atomic adsorption (AA). Concentrations of $\mathrm{Sb}_{t}, \mathrm{As}_{\mathrm{t}}$, and $\mathrm{Se}_{\mathrm{t}}$ were determined using AA with graphite furnace or hydride generation. Total mercury was determined by cold vapor. Concentrations of the common ions chloride $(\mathrm{Cl})$, sulfate $\left(\mathrm{SO}_{4}\right)$, and nutrients, such as total nitrite plus nitrate $\left(\mathrm{NO}_{2}+\mathrm{NO}_{3}\right)$, total nitrite $\left(\mathrm{NO}_{2}\right)$, and total ammonia $\left(\mathrm{NH}_{3}\right)$, were determined by colorimetry, and concentrations of fluoride $(F)$ were determined by ion-specific electrode. A modification of Method 524.2 (Eichelberger and others, 1992) was used to determine concentrations of VOCs in water. Semivolatile organic compounds were analyzed by Method 625 (Code of Federal Regulations, 1994). Concentrations of 47 selected pesticides in water were determined using a USGS method described in Zaugg and others (1995). The minimum reporting levels for this method ranged from 0.001 to $0.018 \mu \mathrm{g} / \mathrm{L}$. Concentrations of XACs in water were determined by gas chromatography using a electron capture detector described in Schumacher and others (1996).

Concentrations of semivolatile organic compounds in sediment were determined using modifications to methods described in SW 846 (U. S. Environ- 
mental Protection Agency, 1986d). Concentrations of XACs in sediment were determined using Method 8330 (U.S. Environmental Protection Agency, 1990). A list of constituents and method reporting levels for inorganic and organic constituents in water and sediment samples and USEPA drinking water maximum contaminant levels (MCL) are given in table 19, at the back of this report.

\section{Quality Assurance}

An extensive quality assurance $(\mathrm{QA})$ program has been implemented by the USGS to ensure the production of scientifically accurate data of known and documented quality. The effectiveness of a QA program is measured by the quality of data generated. Data quality is judged in terms of its accuracy, precision, completeness, representativeness, and comparability. A field sampling plan (FSP) and qualityassurance project plan (QAPP) were developed to describe, in detail, the methods and procedures used by the USGS for the collection, preservation, shipping, and analysis of project environmental samples to ensure that appropriate levels of QA and quality control (QC) were achieved (Sampling and Analysis Plan on file at the USGS in Rolla, Missouri). The QA program was developed to ensure and validate that inconsistencies in field protocols, the field protocols themselves, or analytical protocols do not introduce error into the data-collection process. Onsite QC checks were introduced into the sample collection procedures to minimize (and identify if it occurred) the potential for interference or introduction of contaminants during sample collection, storage, transport, and equipment decontamination. Laboratory QC checks were implemented to ensure the accuracy of the analytical data and minimize, or document the occurrence of, laboratory contamination and variability in analytical results.

Onsite quality checks included the proper calibration of all instruments using standard solutions, the collection of blank and duplicate samples, and adherence to standard sample collection protocols or documentation of variations. The most common error attributable to onsite procedures is contamination of the sample matrix. Two general forms of contamination occur: systematic and erratic. The goal of the field QA program is to decrease the systematic component and provide evidence of the erratic component by:
- Calibrating instruments daily

- Performing duplicate onsite measurements

- Collecting and analyzing equipment blanks

- Collecting and analyzing duplicate samples

- Collecting trip blanks for VOC

Of the 80 water-quality samples collected during the regional assessment of the FLWMR, 8 (10 percent) were duplicate samples. Eight (10 percent) equipment blanks and seven additional VOC trip blanks were collected. Duplicate samples were analyzed for all constituents determined in the original sample. Equipment blanks were analyzed for physical properties and dissolved and total inorganic constituents, VOCs, semivolatile organic compounds, selected pesticides, and XACs. The additional VOC trip blanks were analyzed only for VOCs. A summary of the relative percent difference (RPD) for the various physical properties and inorganic constituents between duplicate and the original samples is given in table 20 , at the back of this report. The median and maximum values detected in the equipment blank samples also are listed in table 20.

Values of physical properties and concentrations of constituents in duplicate samples were similar to those in the original samples. To assess the general comparability of duplicate samples to original samples, a median RPD was calculated for each physical property or inorganic chemical constituent. The median RPD was derived by calculating the percent difference between each pair of sample and duplicate values and computing a median of those eight values. Generally, the RPD between the duplicate and original sample values was less than 5 percent (table 20). The largest median RPD between duplicate and original samples was for total phosphorus $\left(\mathrm{P}_{t}\right)$, boron $(\mathrm{B})$, and iron ( $\mathrm{Fe}$ ) with median RPD values of 28,33 , and 13 percent (table 20). The concentrations of these constituents in the samples and duplicates were at or near the reporting levels, where large variations can be expected to occur.

Values of physical properties and concentrations of inorganic constituents in the equipment blank samples generally were small as compared to concentrations detected in water samples. Maximum concentrations of major constituents were less than $1 \mathrm{mg} / \mathrm{L}$, and maximum concentrations of trace elements were near the reporting levels except for B $(20 \mu \mathrm{g} / \mathrm{L}), \mathrm{Fe}(7$ $\mu \mathrm{g} / \mathrm{L})$, total iron $\left(\mathrm{Fe}_{t}, 10 \mu \mathrm{g} / \mathrm{L}\right), \mathrm{Pb}(50 \mu \mathrm{g} / \mathrm{L})$, zinc $(\mathrm{Zn}, 8 \mu \mathrm{g} / \mathrm{L})$, and total zinc $\left(\mathrm{Zn}_{\mathrm{t}}, 4 \mu \mathrm{g} / \mathrm{L}\right)$. Although the maximum concentrations of these constituents 
approached concentrations detected in some of the environmental samples, the median concentrations in the blanks were near or less than the reporting levels.

A review of the analytical data for inorganic constituents in ground-water (table 21, at the back of this report), spring (table 22, at the back of this report), and surface-water (table 23, at the back of this report) samples indicated that concentrations of calcium $(\mathrm{Ca})$, barium $(\mathrm{Ba})$, and $\mathrm{Pb}$ were commonly larger than concentrations of total calcium $\left(\mathrm{Ca}_{\mathrm{t}}\right)$, total barium $\left(\mathrm{Ba}_{\mathrm{t}}\right)$, and total lead $\left(\mathrm{Pb}_{\mathrm{t}}\right)$. Dissolved inorganic constituents were analyzed at the USGS laboratory in Arvada, Colorado, using a simultaneous scanning vertical torch ICP, whereas total inorganic constituents were analyzed at the USGS laboratory in Ocala, Florida, using a total digestion (U.S. Environmental Protection Agency Method 200.7) and a sequential scanning inclined torch ICP. Except for $\mathrm{Pb}$, the differences are small as compared to the actual concentrations of $\mathrm{Ca}$, $\mathrm{Ba}, \mathrm{Ca}_{\mathrm{t}}$, and $\mathrm{Ba}_{\mathrm{t}}$ in the water samples and are not significant. The most probable explanation is a slight (about 5 percent) analytical bias between the methods used at the two laboratories.

Because the solubility of $\mathrm{Pb}$ in water at nearneutral $\mathrm{pH}$ values is less than $1 \mu \mathrm{g} / \mathrm{L}$, reported values of $\mathrm{Pb}$ in the tens of micrograms per liter are suspect. The maximum $\mathrm{Pb}$ concentration $(50 \mu \mathrm{g} / \mathrm{L})$ detected in the blank samples (table 20) indicates the determination of $\mathrm{Pb}$ in water samples in this study may be unreliable. A possible source of the anomalous $\mathrm{Pb}$ concentrations is contamination during sample collection and preservation. Samples for $\mathrm{Pb}$ and $\mathrm{Pb}_{\mathrm{t}}$ are treated identically except samples for $\mathrm{Pb}$ determination are pumped through a disposable capsule filter. Filter contamination is possible; however, all filter lots are quality checked for metal contamination by the USGS laboratory in Ocala, Florida, prior to use. Several water samples from the FLWMR also had reported $\mathrm{Pb}$ concentrations substantially larger than the reporting level of $10 \mu \mathrm{g} / \mathrm{L}$ and significantly larger than reported concentrations for $\mathrm{Pb}_{\mathrm{t}}$. Contamination during sampling is possible; however, contamination also would be expected to affect $\mathrm{Pb}_{\mathrm{t}}$ concentration. The small $\mathrm{Pb}_{\mathrm{t}}$ concentration indicates contamination is unlikely. The $\mathrm{QA}$ data and comparison of $\mathrm{Pb}$ and $\mathrm{Pb}_{\mathrm{t}}$ in water samples indicates that concentrations of $\mathrm{Pb}$ determined by vertical torch ICP probably are less reliable than those determined by inclined torch ICP.

None of the blank samples contained detectable concentrations of semivolatile organic compounds, selected pesticides, or XACs; however, one VOC blank contained a chloromethane concentration of 1.8 $\mu \mathrm{g} / \mathrm{L}$ (table 24 , at the back of this report). In addition, a comparison of acidified and unacidified VOC water samples indicated the trihalomethane (THM) compounds, chloromethane, and trichloromethane were present only in the acidified samples. A thorough review of the QA samples and blanks indicates that chloromethane and trichloromethane were present as contaminants in the $\mathrm{HCl}$ used to preserve VOC samples collected between January and July 1995. Water samples that contained only chloromethane or trichloromethane without other VOCs are suspect and probably indicate contamination from the preservative. Interferences from the contaminated acid resulted in the reporting levels for several THM in several samples being raised from 0.02 to $0.4 \mu \mathrm{g} / \mathrm{L}$. These samples are identified in table 24. After the contamination was discovered, fresh $\mathrm{HCl}$ was used to preserve samples collected after August 1, 1995.

\section{Regional Ground-Water Quality}

The USGS collected 34 (includes 2 duplicates) samples from 23 wells at the FLWMR during 1995 (fig. 21). Analytical data for these samples are given in table 21. All wells except wells dw 027, dw 061, and $\mathrm{dw} 064$ were sampled during high-base flow conditions between February and May 1995. Samples were collected for the determination of dissolved and total inorganic constituents, total nutrients, VOCs, semivolatile organic compounds, selected pesticides, and XACs. To determine if ground-water quality varied with season, nine of the wells were sampled again during low-base flow conditions in August 1995. Wells were not sampled for pesticides or XACs during the low-base flow sampling. No obvious difference in water quality was detected between the high- and lowbase flow samples; however, samples from a number of wells indicate the effects of human or animal wastes or nitrogen-containing fertilizers. Several well samples also contained detectable pesticide concentrations.

Concentrations of major cations and anions and trace elements in well samples were used to establish background concentrations for ground water at the FLWMR. The range and 95th percentile of physical properties, major cations and anions, and trace elements in ground-water samples are included in table 25 . The 95 th percentile represents the value for which 


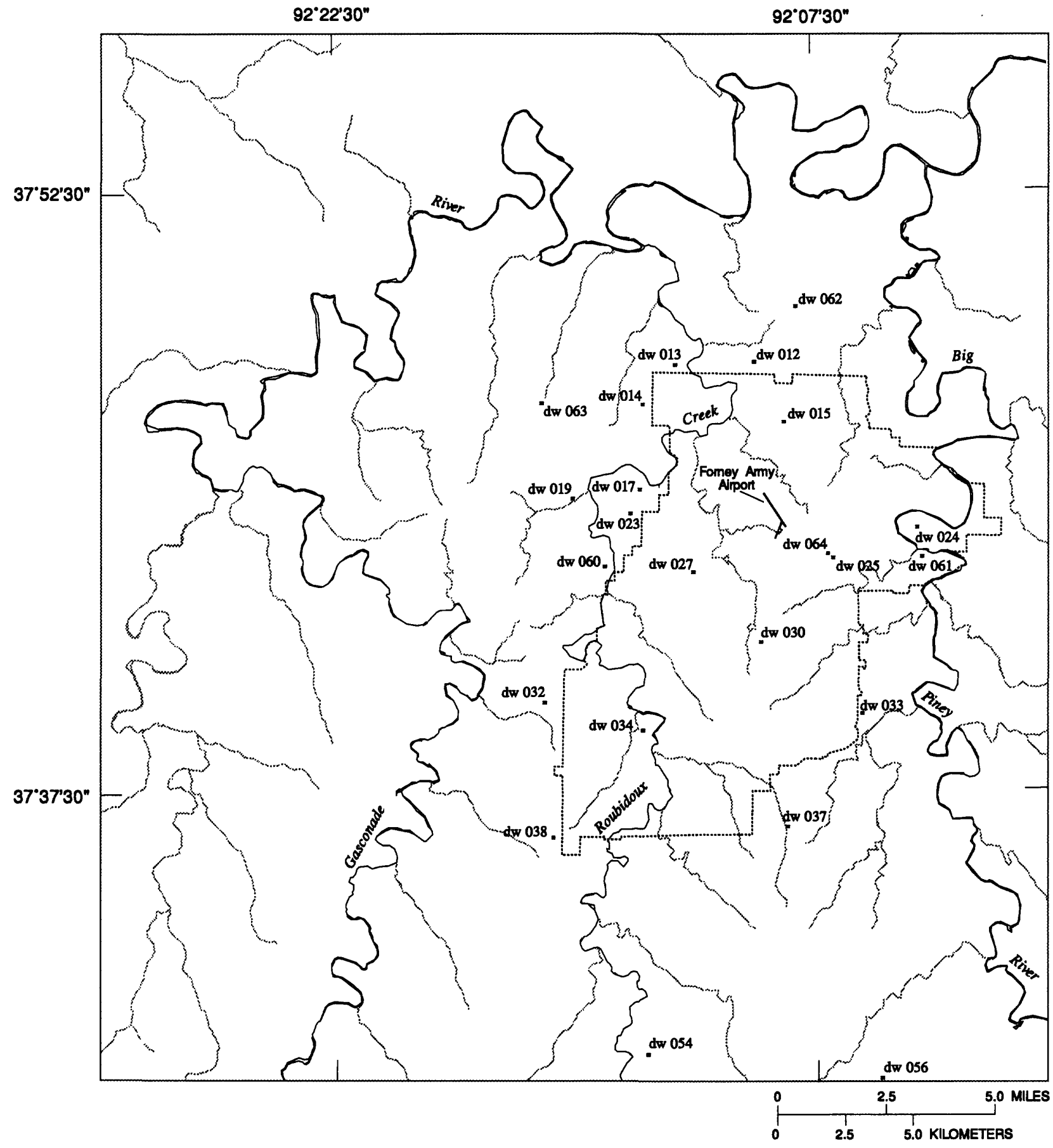

EXPLANATION

FORT LEONARD WOOD MIITARY RESERVATION BOUNDARY

dw 038. GROUND-WATER SAMPLING SITE AND WELL IDENTIFIER

Figure 21. Location of domestic and public-supply wells sampled at and near the Fort Leonard Wood Military Reservation. 
Table 25. Background concentrations of selected physical properties and major and trace inorganic constituents in groundwater, spring, and surface-water samples at and near the Fort Leonard Wood Military Reservation

$\left[\mu \mathrm{S} / \mathrm{cm}\right.$, microsiemens per centimeter at 25 degrees Celsius; ${ }^{\circ} \mathrm{C}$, degrees Celsius; $\mathrm{mg} / \mathrm{L}$, milligrams per liter, <, less than; col/100 mL; colonies per 100 milliliters; --, no data available; $\mu \mathrm{g} / \mathrm{L}$, micrograms per liter, $\leq$, less than or equal to]

\begin{tabular}{|c|c|c|c|c|c|c|}
\hline \multirow[b]{2}{*}{$\begin{array}{l}\text { Physical property or } \\
\text { chemical constituent }\end{array}$} & \multicolumn{2}{|c|}{ Ground water (wells) } & \multicolumn{2}{|c|}{ Spring } & \multicolumn{2}{|c|}{ Surface water } \\
\hline & Range & $\begin{array}{c}\text { 95th } \\
\text { percentlle }\end{array}$ & Range & $\begin{array}{c}\text { 95th } \\
\text { percentlle }\end{array}$ & Range & $\begin{array}{c}\text { 95th } \\
\text { percentlle }\end{array}$ \\
\hline Specific conductance $(\mu \mathrm{S} / \mathrm{cm})$ & $315-680$ & 510 & $203-434$ & 390 & $211-548$ & 359 \\
\hline Temperature $\left({ }^{\circ} \mathrm{C}\right)$ & $11.5-21$ & 18.0 & $2.5-23.5$ & 18.8 & $4.5-31$ & 29 \\
\hline $\mathrm{pH}$ (standard units) & 7.3-7.9 & 7.9 & $6.8-8.2$ & 7.8 & 7.3-8.2 & 8.2 \\
\hline Calcium (mg/L) & $.2-75$ & 68 & $21-45$ & 44 & $24-55$ & 38 \\
\hline Calcium, total (mg/L) & $.1-72$ & 65 & $19-44$ & 42 & $23-53$ & 36 \\
\hline Magnesium (mg/L) & $.1-42$ & 38 & $11-25$ & 24 & $13-32$ & 22 \\
\hline Magnesium, total (mg/L) & $.1-43$ & 38 & $12-27$ & 26 & $14-31$ & 24 \\
\hline Sodium (mg/L) & $1.3-150$ & 4.4 & $.9-7$ & 2.9 & $.9-39$ & 3.5 \\
\hline Sodium, total (mg/L) & $1.4-150$ & 5.0 & $1-7.2$ & 3 & $.9-38$ & 3.7 \\
\hline Potassium (mg/L) & $.2-2.2$ & 1.7 & $.9-2.3$ & 2 & $.8-7.4$ & 2.7 \\
\hline Bicarbonate (mg/L) & $192-438$ & 344 & $108-264$ & 257 & $113-294$ & 220 \\
\hline Chloride $(\mathrm{mg} / \mathrm{L})$ & $1.0-37$ & 6.2 & $1.1-9.6$ & 4.7 & $.7-38$ & 4.7 \\
\hline Sulfate $(\mathrm{mg} / \mathrm{L})$ & $1.8-26$ & 15 & 4.3-17 & 9.4 & $2.9-44$ & 6.8 \\
\hline Fluoride $(\mathrm{mg} / \mathrm{L})$ & $<.1-0.6$ & .1 & $<.1-.2$ & $<.1$ & $<.1-.7$ & $<.3$ \\
\hline Nitrate plus nitrite, total (mg/L) & $<.02-7.2$ & 1 & $<.02-2.0$ & 0.7 & $<.02-2.7$ & .5 \\
\hline Nitrite, total $(\mathrm{mg} / \mathrm{L})$ & $<.001-.02$ & $<.01$ & $<.001-.01$ & $<.01$ & $<.001-.26$ & $<.01$ \\
\hline Ammonia, total $(\mathrm{mg} / \mathrm{L})$ & $<.01-.03$ & .03 & $<.01-.05$ & .04 & $<.01-8.4$ & .04 \\
\hline Phosphorus, total (mg/L) & $<.02-.03$ & $<.03$ & $<.02-.38$ & $<.04$ & $<.02-1.5$ & $<.03$ \\
\hline Alkalinity, it, total (mg/L) & $157-359$ & 282 & $89-216$ & 212 & $92-241$ & 206 \\
\hline Total organic carbon (mg/L) & $<.1-88$ & 2.8 & $.7-36$ & 15.4 & $.8-7.7$ & 3.8 \\
\hline Dissolved solids, sum of constituents (mg/L) & $170-382$ & 290 & $108-252$ & 226 & $130-286$ & 222 \\
\hline Hardness, total (mg/L) & $1-360$ & 286 & $98-220$ & 207 & $110-270$ & 198 \\
\hline Fecal Coliform (col/100 mL) & -- & -- & $0-810$ & 180 & $<2-1,000$ & 428 \\
\hline Fecal Strep $(\mathrm{col} / 100 \mathrm{~mL})$ & -- & -- & $0-360$ & 280 & $<2-540$ & 430 \\
\hline Antimony, total $(\mu \mathrm{g} / \mathrm{L})$ & $<1-2$ & $<1$ & $\leq 1$ & 1 & $\leq 1$ & 1 \\
\hline Arsenic, total $(\mu \mathrm{g} / \mathrm{L})$ & $\leq 1$ & $<1$ & $\leq 1$ & 1 & $\leq 1$ & 1 \\
\hline Barium $(\mu \mathrm{g} / \mathrm{L})$ & $25-210$ & 144 & $35-58$ & 54 & $23-88$ & 64 \\
\hline Barium, total $(\mu \mathrm{g} / \mathrm{L})$ & $20-200$ & 140 & $40-50$ & 50 & $30-80$ & 66 \\
\hline Beryllium $(\mu \mathrm{g} / \mathrm{L})$ & $<.5$ & $<.5$ & $<.5$ & $<.5$ & $<.5-19$ & $<1$ \\
\hline Beryllium, total $(\mu \mathrm{g} / \mathrm{L})$ & $<.5-2.5$ & $<.5$ & $<.5-1.3$ & .5 & $<.5-1.4$ & 1.3 \\
\hline Boron $(\mu \mathrm{g} / \mathrm{L})$ & $<10-20$ & $<20$ & $<10-110$ & 21 & $<10-140$ & 30 \\
\hline Boron, total $(\mu \mathrm{g} / \mathrm{L})$ & 220 & $<20$ & $<20-120$ & 20 & $<20-150$ & 20 \\
\hline Cadmium $(\mu \mathrm{g} / \mathrm{L})$ & $<1-2$ & $<1$ & $<1-3$ & $<3$ & $<1-3$ & $<2$ \\
\hline Cadmium, total $(\mu \mathrm{g} / \mathrm{L})$ & 21 & $<1$ & 21 & 1 & $\leq 1$ & 1 \\
\hline Chromium $(\mu \mathrm{g} / \mathrm{L})$ & $<5$ & $<5$ & $<5$ & $<5$ & $<5$ & $<5$ \\
\hline Chromium, total $(\mu \mathrm{g} / \mathrm{L})$ & 25 & $<5$ & 25 & 5 & $\leq 5$ & 5 \\
\hline Cobalt $(\mu \mathrm{g} / \mathrm{L})$ & $<3$ & $<3$ & $<3$ & $<3$ & $<3$ & $<3$ \\
\hline
\end{tabular}


Table 25. Background concentrations of selected physical properties and major and trace inorganic constituents in groundwater, spring, and surface-water samples at and near the Fort Leonard Wood Military Reservation-Continued

\begin{tabular}{|c|c|c|c|c|c|c|}
\hline \multirow[b]{2}{*}{$\begin{array}{l}\text { Physical property or } \\
\text { chemical constituent }\end{array}$} & \multicolumn{2}{|c|}{ Ground water (wells) } & \multicolumn{2}{|c|}{ Spring } & \multicolumn{2}{|c|}{ Surface water } \\
\hline & Range & $\begin{array}{c}\text { 95th } \\
\text { percentlle }\end{array}$ & Range & $\begin{array}{c}\text { 95th } \\
\text { percentlle }\end{array}$ & Range & $\begin{array}{c}\text { 95th } \\
\text { percentlle }\end{array}$ \\
\hline Cobalt, total $(\mu \mathrm{g} / \mathrm{L})$ & $<3-4$ & $<3$ & 23 & 3 & $\leq 3$ & 3 \\
\hline Copper $(\mu \mathrm{g} / \mathrm{L})$ & $<10-40$ & 17 & $<10$ & $<10$ & $<10$ & $<10$ \\
\hline Copper, total $(\mu \mathrm{g} / \mathrm{L})$ & $<10-40$ & $<20$ & 210 & 10 & $\leq 10$ & 10 \\
\hline Iron $(\mu \mathrm{g} / \mathrm{L})$ & $<3-75$ & $<64$ & $<3-110$ & 43 & $<3-80$ & 51 \\
\hline Iron, total $(\mu \mathrm{g} / \mathrm{L})$ & $4-750$ & 225 & $10-230$ & 200 & $7-470$ & $<285$ \\
\hline Lead $(\mu \mathrm{g} / \mathrm{L})$ & $<10-40$ & $<10$ & $<10-60$ & $<10$ & $<1-40$ & $<10$ \\
\hline Lead, total $(\mu \mathrm{g} / \mathrm{L})$ & $\leq 10$ & 10 & $\leq 10$ & 10 & $<10-18$ & 10 \\
\hline Lithium $(\mu \mathrm{g} / \mathrm{L})$ & $<4-9$ & $<7$ & $<4$ & $<4$ & $<4-5$ & 5 \\
\hline Manganese $(\mu \mathrm{g} / \mathrm{L})$ & $<1-5$ & 2 & $<1-290$ & $<75$ & $<1-160$ & $<58$ \\
\hline Manganese, total $(\mu \mathrm{g} / \mathrm{L})$ & $<1-33$ & 1 & $1-330$ & 136 & $1-240$ & $<58$ \\
\hline Mercury, total $(\mu \mathrm{g} / \mathrm{L})$ & $\leq .1$ & $<.1$ & $<.1-.3$ & $<.2$ & $<.1-.2$ & $<.2$ \\
\hline Molybdenum $(\mu \mathrm{g} / \mathrm{L})$ & $<10-20$ & $<10$ & $<10-30$ & $<10$ & $\leq 10$ & $<10$ \\
\hline Nickel $(\mu \mathrm{g} / \mathrm{L})$ & $<10$ & $<10$ & $<10$ & $<10$ & $\leq 10$ & $<10$ \\
\hline Nickel, total $(\mu \mathrm{g} / \mathrm{L})$ & $\leq 10$ & $<10$ & $\leq 10$ & 10 & $\leq 10$ & 10 \\
\hline Selenium, total $(\mu \mathrm{g} / \mathrm{L})$ & $<1$ & $<1$ & $\leq 1$ & 1 & $\leq 1$ & $<1$ \\
\hline Silver $(\mu \mathrm{g} / \mathrm{L})$ & $<1-3$ & 1 & $\leq 1$ & $<1$ & $<1-2$ & $<2$ \\
\hline Silver, total $(\mu \mathrm{g} / \mathrm{L})$ & $\leq 1$ & $<1$ & $\leq 1$ & 1 & $\leq 1$ & 1 \\
\hline Strontium $(\mu \mathrm{g} / \mathrm{L})$ & $<1-62$ & 59 & $28-51$ & 49 & $24-58$ & $<48$ \\
\hline Thallium, total $(\mu \mathrm{g} / \mathrm{L})$ & $\leq 1$ & $<1$ & $\leq 1$ & 1 & $\leq 1$ & 1 \\
\hline Vanadium $(\mu \mathrm{g} / \mathrm{L})$ & $\leq 6$ & $<6$ & $<6$ & $<6$ & $<6$ & $<6$ \\
\hline Vanadium, total $(\mu \mathrm{g} / \mathrm{L})$ & $\leq 1$ & $<1$ & $\leq 1$ & 1 & $<1-2$ & 1 \\
\hline $\operatorname{Zinc}(\mu \mathrm{g} / \mathrm{L})$ & $<3-750$ & $<445$ & $<3-6$ & $<6$ & $<3-10$ & $<8$ \\
\hline Zinc, total $(\mu \mathrm{g} / \mathrm{L})$ & $<4-760$ & $<410$ & $<4-20$ & $<10$ & $<4-20$ & $<9$ \\
\hline
\end{tabular}

95 percent of the samples are equal to or less than. The 95th percentile was assumed to represent a conservative approximation of the upper limit of background values. A subjective iterative procedure was followed. If a constituent value for a particular sample exceeded the 95th percentile, the sample was examined closely to determine if other physical properties or constituents exceeded their respective 95 th percentiles. For example, physical properties and constituents commonly related to similar sources, such as increased specific conductance values and $\mathrm{Na}, \mathrm{Cl}$, and nutrient concentrations associated with effects from septic tanks or feed lots, were considered to represent nonbackground conditions. The values for these constitu- ents were listed in table 21 and, although listed in the range, were not used to calculate the 95 th percentiles for the particular constituents (table 25). A sample from well dw 023 (table 21) was not used to calculate the 95th percentiles. This sample contained concentrations of $\mathrm{Ca}, \mathrm{Ca}_{\mathrm{t}}, \mathrm{Mg}$, and $\mathrm{Mg}_{\mathrm{t}}$ less than $1 \mathrm{mg} / \mathrm{L}$ and concentrations of $\mathrm{Na}$, and $\mathrm{Na}_{\mathrm{t}}$ of $150 \mathrm{mg} / \mathrm{L}$. This sample was inadvertently collected from a tap down line of a water softener, and concentrations of major cations and anions and trace elements are not representative of background conditions.

Ground-water quality at the FLWMR is similar to the regional water quality of the Ozark aquifer described by Imes and Davis (1991). Imes and Davis 
(1991) indicated that ground water in the Ozark aquifer in south-central Missouri generally is a Ca-Mg$\mathrm{HCO}_{3}$ type with $\mathrm{Cl}$ and $\mathrm{SO}_{4}$ concentrations less than $10 \mathrm{mg} / \mathrm{L}$ and dissolved solids less than $300 \mathrm{mg} / \mathrm{L}$. Ground water at the FLWMR has specific conductance values ranging from 315 to $680 \mu \mathrm{S} / \mathrm{cm}$ (background 95th percentile of $510 \mu \mathrm{S} / \mathrm{cm}), \mathrm{pH}$ values about 7.5, and $\mathrm{Ca}, \mathrm{Mg}$, and $\mathrm{HCO}_{3}$ as the predominant ions. Concentrations of dissolved solids generally were less than $300 \mathrm{mg} / \mathrm{L}$ (table 21). Samples from most wells plot within a narrow field on a trilinear diagram near the $\mathrm{Ca}$ plus $\mathrm{Mg}-\mathrm{CO}_{3}$ plus $\mathrm{HCO}_{3}$ vertex (fig. 22), reflecting the predominately carbonate lithology of the Roubidoux Formation, Gasconade Dolomite, Eminence Dolomite, and Potosi Dolomite. Samples from wells dw 038 and dw 056 have large concentrations of $\mathrm{Cl}$ (37 and $22 \mathrm{mg} / \mathrm{L}$ ) and plot outside the background range for ground water. Molar ratios of $\mathrm{Ca}$ to $\mathrm{Mg}$ in groundwater samples range from 0.97 to 1.18 with a median of 1.1. Ground water in equilibrium with limestone (predominately comprised of the mineral calcite) would be expected to have ratios much larger than one (Hem, 1992). Molar ratios of $\mathrm{Ca}$ to $\mathrm{Mg}$ of one generally indicate that dissolution of the mineral dolomite is the primary source of $\mathrm{Ca}$ and $\mathrm{Mg}$ in solution. Equilibrium speciation calculations using the geochemical code WATEQ4F (Ball and others, 1987) indicate that all ground-water samples (except the sample from well $\mathrm{dw}$ 023) were at equilibrium with the minerals calcite $\left(\mathrm{CaCO}_{3}\right)$ and dolomite $\left[(\mathrm{Ca}, \mathrm{Mg})\left(\mathrm{CO}_{3}\right)_{2}\right]$, indicating that equilibrium with these minerals controls the $\mathrm{pH}$ and concentrations of $\mathrm{Ca}, \mathrm{Mg}$, and $\mathrm{HCO}_{3}$. Ground-water samples plot along the line for weathering of carbonate material by carbonic acid (fig. 23), according to the equation:

$$
\begin{gathered}
\mathrm{CO}_{2}+\mathrm{H}_{2} \mathrm{O}+(\mathrm{Ca}, \mathrm{Mg}, \mathrm{Sr}) \mathrm{CO}_{3}= \\
(\mathrm{Ca}, \mathrm{Mg}, \mathrm{Sr})^{2+}+2 \mathrm{HCO}_{3}{ }^{1-}
\end{gathered}
$$

rather than mineral acid dissolution or hydrolysis. The slopes of the regression lines for well (0.57) and spring $(0.58)$ samples are similar to the theoretical slope of 0.5 from equation 1 .

Samples from wells dw 017, dw 019, dw 024, dw 030, dw 033, dw 037, dw 038, dw 054, and dw 056 indicate effects of human or animal wastes or fertilizers on ground-water quality. Larger than background concentrations of $\mathrm{Na}, \mathrm{Na}_{\mathrm{t}}, \mathrm{Cl}$, and $\mathrm{NO}_{2}+\mathrm{NO}_{3 \mathrm{t}}$ were detected in samples from wells dw 024, dw 030, dw 037 , dw 038, and dw 056. Well dw 024 is located at the FLWMR golf course and also may be affected by fertilizers applied on the golf course. The larger than background concentration of $\mathrm{Cl}(6.3 \mathrm{mg} / \mathrm{L})$ in the sample from well dw 033 also may indicate the effects of septic or animal waste, considering that the $\mathrm{NO}_{2}+\mathrm{NO}_{3 \mathrm{t}}$ concentration was at the background concentration of $1 \mathrm{mg} / \mathrm{L}$. The larger than background concentrations of $\mathrm{NO}_{2}+\mathrm{NO}_{3 \mathrm{t}}$ in samples from wells $\mathrm{dw}$ 017 (6.9 mg/L), dw $019(7.2 \mathrm{mg} / \mathrm{L})$, and dw 054 (3.8 $\mathrm{mg} / \mathrm{L}$ ) were somewhat anomalous because they were not associated with larger than background concentrations of $\mathrm{Na}, \mathrm{Na}_{\mathrm{t}}$, or $\mathrm{Cl}$ (table 21). Samples from wells dw 019, dw 033, dw 037, dw 054, and dw 056 also have larger than background concentrations of TOC, possibly related to human or animal wastes.

Concentrations of most trace elements in ground-water samples generally were less than detection or less than a few tens of micrograms per liter except for $\mathrm{Ba}, \mathrm{Ba}_{\mathrm{t}}, \mathrm{Fe}_{\mathrm{t}}$, strontium (Sr), $\mathrm{Zn}$, and $\mathrm{Zn}_{\mathrm{t}}$. Carbonate rock forming minerals such as calcite and dolomite contain trace quantities of $\mathrm{Ba}$ and $\mathrm{Sr}$, and concentrations of these constituents in ground water are largely derived from dissolution of these minerals by percolating water. Concentrations of $\mathrm{Ba}$, however, commonly are limited by the solubility of the mineral barite $\left(\mathrm{BaSO}_{4}\right)$. Indeed, samples from wells dw 017 , dw 030, dw 032, dw 034, and dw 062 are at equilibrium with barite. Barite is present in the weathered residuum overlying bedrock throughout much of the Ozarks and dissolution of this mineral also could contribute to the large $\mathrm{Ba}$ and $\mathrm{Ba}_{\mathrm{t}}$ concentrations detected in samples from well dw $034(210$ and $200 \mu \mathrm{g} / \mathrm{L})$. Oxidation and dissolution of the mineral pyrite $\left(\mathrm{FeS}_{2}\right)$ within the bedrock is a potential source of $\mathrm{Fe}$ in the ground water. The solubility of $\mathrm{Fe}\left(\mathrm{Fe}^{3+}\right)$ oxy-hydroxides is small, however, and Fe commonly is present as colloidal or small particles in ground water. Generally, concentrations of $\mathrm{Fe}_{\mathrm{t}}$ were substantially larger than $\mathrm{Fe}$, indicating most $\mathrm{Fe}$ is present in the particulate phase. In addition, corrosion of common well construction materials such as steel casings, pumps, pump riser pipes, and steel and galvanized water pipes can contribute to $\mathrm{Fe}$ detected in ground-water samples. Thirteen ground-water samples contained large (68 to 760 $\mu \mathrm{g} / \mathrm{L}$ ) concentrations of dissolved $\mathrm{Zn}$ or $\mathrm{Zn}_{\mathrm{t}}$. Generally, increased $\mathrm{Zn}$ concentrations are associated with $\mathrm{Zn}$-bearing minerals such as sphalerite $(\mathrm{ZnS})$ or cerussite $\left[\mathrm{Zn}\left(\mathrm{CO}_{3}\right)\right]$; however, $\mathrm{Zn}$ mineralization is not known to occur in the vicinity of the FLWMR, and the most likely source for the increased $\mathrm{Zn}$ and $\mathrm{Zn}_{\mathrm{t}}$ con- 


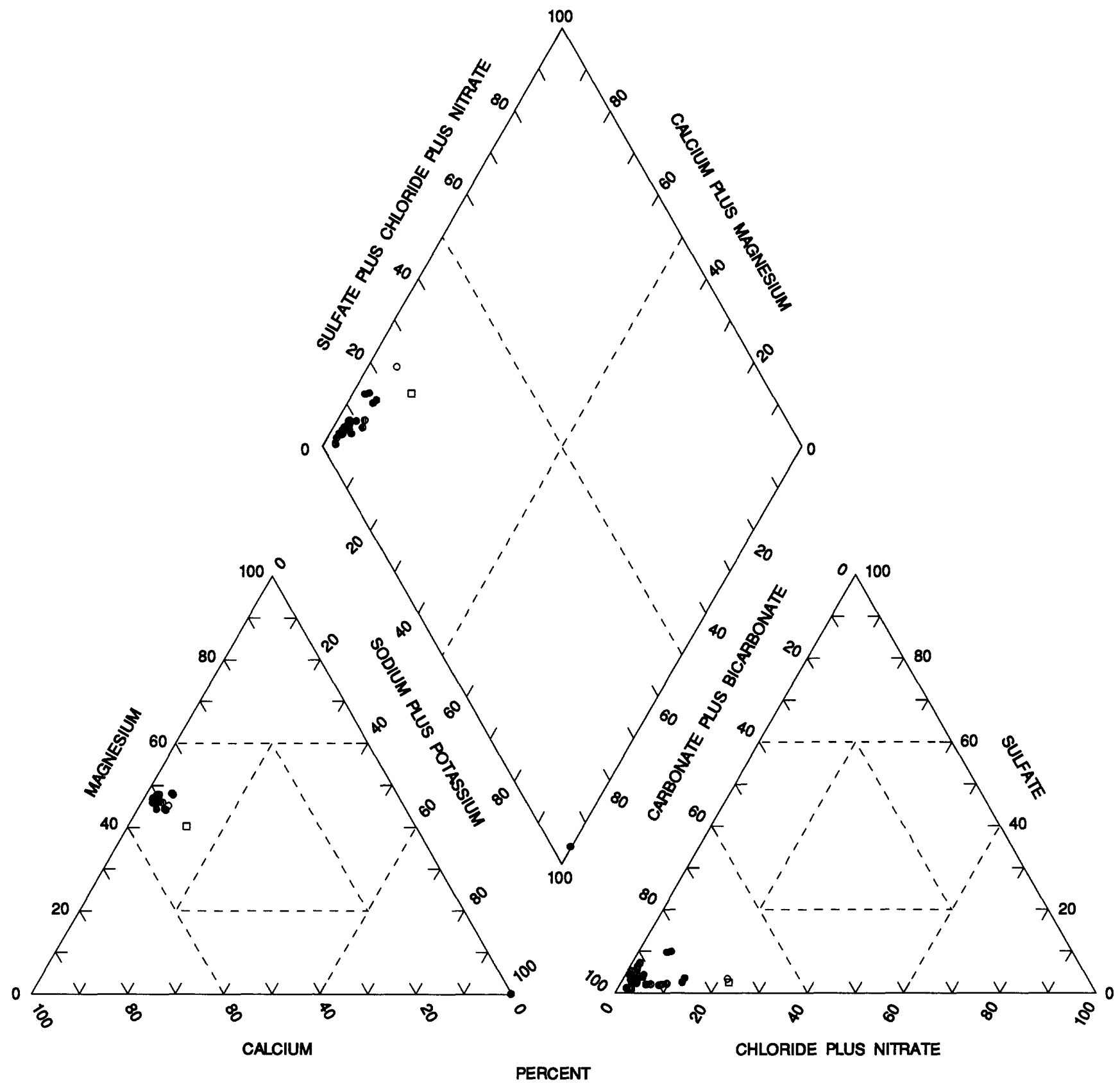

NORMAUZED MIUEQUIVALENTS OF MAJOR IONS

EXPLANATION

- WEL SAMPLE

- WEL dW 038

口 WELL dW 056

Figure 22. Trilinear diagram depicting relative concentrations of major cations and anions in ground-water samples. 


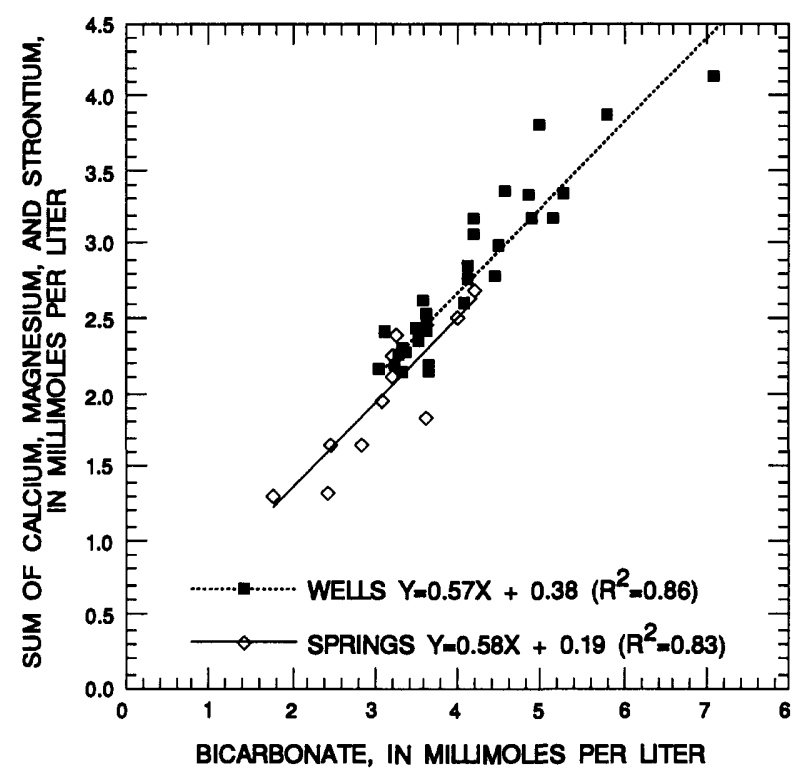

Figure 23. Sum of calcium, magnesium, and strontium as related to bicarbonate in water samples from wells and springs at the Fort Leonard Wood Military Reservation.

centrations is the corrosion of galvanized pipes used in many domestic and public-supply wells.

Samples from wells dw 015, dw 024, dw 025, $\mathrm{dw}$ 030, dw 061, and dw 064 contained small (less than $1.6 \mu \mathrm{g} / \mathrm{L}$ ) concentrations of THM, such as chloromethane, trichloromethane, bromomethane, bromodichloromethane, dibromochloromethane, and bromoform, that probably are the result of chlorination of the wells or a contaminant from the $\mathrm{HCl}$ used to preserve some samples (as previously discussed in the "Quality Assurance Section," table 24). Chlorine in the form of household bleach commonly is used to disinfect domestic and public-supply wells after installation or servicing or is poured down wells with known bacterial contamination. Bromine is present in trace quantities in bleach and is the probable source of the bromine-containing THM. Well dw 064 is a new supply well for an ammunition storage area. This well was sampled shortly after it was completed, and the concentrations of trichloromethane $(0.9 \mu \mathrm{g} / \mathrm{L})$, bromodichloromethane $(0.7 \mu \mathrm{g} / \mathrm{L})$, and dibromochloromethane $(0.5 \mu \mathrm{g} / \mathrm{L})$ detected probably are related to bleach used to disinfect this well after it was completed. Only three ground-water samples contained detectable concentrations of VOCs other than THM. A sample from well dw 015 (August 29, 1995) contained total xylene concentrations of $0.3 \mu \mathrm{g} / \mathrm{L}$, and a sample from well dw 024 (August 29, 1995) and a duplicate sample from well dw 030 (August 30,1995) contained methyltert-butylether (MTBE) concentrations of 0.3 and $0.6 \mu \mathrm{g} / \mathrm{L}$. Xylene and MTBE commonly are present in fuels such as gasoline. A sample collected from well dw 033 (February 23, 1995) contained acetone $(1.4 \mu \mathrm{g} / \mathrm{L})$ and 2-butanone $(0.2 \mu \mathrm{g} / \mathrm{L})$, which are contaminants traced to a permanent marker used to label VOC vials from this well.

Several non-target VOCs were tentatively identified in samples from wells dw 015, dw 024, and dw 060. Samples from well dw 015 contained dibromomethylbenzene (estimated at $0.1 \mu \mathrm{g} / \mathrm{L}$ ), 1-bromo-3,5dimethylbenzene (estimated at $0.3 \mu \mathrm{g} / \mathrm{L}$ ), and 4bromo-1,2-dimethylbenzene (estimated at $0.2 \mu \mathrm{g} / \mathrm{L}$ ). Brominated benzene derivatives are somewhat unusual and probably are formed during the chlorination of wells. The parent compound of the brominated benzene derivatives, however, is most likely a substituted benzene such as xylene, indicating small xylene concentrations may be present in ground water near this well. A sample collected from well dw 024 (April $6,1995)$ contained the non-target VOCs cyanogen chloride, 2-methylpropanal, and pentanal $(0.1 \mu \mathrm{g} / \mathrm{L})$. Cyanogen chloride is a highly toxic compound (Budavari and others, 1989). This compound probably is formed during chlorination similar to many of the THM. The sample from well dw 060 contained the tentatively identified non-target VOC 2,4-dimethyl heptane (estimated at $0.1 \mu \mathrm{g} / \mathrm{L}$ ).

No semivolatile organic compounds or XACs were detected in any ground-water samples; however, dissolved pesticides were detected in samples from wells dw 014, dw 032, dw 033, and dw 060. Diazinon was the most commonly detected pesticide, detected at $5 \mathrm{ng} / \mathrm{L}$ (nanograms per liter) in samples from wells $d \mathrm{w}$ 014 and dw 032 and at $7 \mathrm{ng} / \mathrm{L}$ in the sample from well $\mathrm{dw} 060$. The sample from well $\mathrm{dw} 033$ contained a trace quantity $(2 \mathrm{ng} / \mathrm{L})$ of $p, p^{\prime}-\mathrm{DDE}$, a degradation product of DDT. Tebuthiuron was detected at $14 \mathrm{ng} / \mathrm{L}$ in the sample from well dw 060. Tebuthiuron is a nonselective herbicide used in rangelands, rights-of-way, and industrial areas (Meister Publishing Company, 1994). The effects of pesticides, human or animal wastes, and fertilizer on the water quality in several sampled wells indicates much of the shallow ground water at the FLWMR and vicinity is susceptible to contamination from surficial sources. 


\section{Spring-Water Quality}

The USGS collected 19 water samples (including 3 duplicates) from 9 springs at and near the FLWMR between March 1 and September 1, 1995 (fig. 24). Springs were to be sampled during high-base flow (spring) and low-base flow (July-August) conditions; however, Ballard Hollow Spring, Musgrave Hollow spring 1, and Tunnel Hollow Spring were dry during the low-base flow sampling and Cannon Range Spring was not sampled during high-base flow conditions. Springs were sampled for dissolved and total inorganic constituents, total nutrients, VOCs, semivolatile organics scan by GC-FID, selected pesticides, and XACs at high-base flow, and for all the above except for pesticides at low-base flow. Analytical data for these samples and 11 additional water samples collected from Roubidoux Spring as part of the USGS ambient water-quality program are listed in table 22 . Background concentrations of physical properties and chemical constituents were calculated in a similar manner as those for ground-water samples and are listed in table 25. Except for Shanghai Spring, spring discharges were substantially smaller during the lowbase flow sampling in August 1995 than during highbase flow conditions. A review of 17 discharge measurements made by the USGS at Shanghai Spring between 1992 and 1996 indicates that discharge is similar during high- and low-base flow conditions (data on file at the USGS, Rolla, Missouri).

Water samples from springs had specific conductance values ranging from 203 to $434 \mu \mathrm{S} / \mathrm{cm}$ and plot near the $\mathrm{Ca}, \mathrm{Mg}-\mathrm{HCO}_{3}$ vertex on a trilinear diagram (fig. 25). Similar to ground-water samples from wells, water samples from springs had $\mathrm{pH}$ values of about 7.5 and $\mathrm{Ca}, \mathrm{Mg}$, and $\mathrm{HCO}_{3}$ as the principal ions (table 22).

Spring samples also plot along the weathering line of carbonate material by carbonic acid (fig. 23) and have molar ratios of $\mathrm{Ca}$ to $\mathrm{Mg}$ of about 1.1, indicating dissolution of dolomite is the principle source of major ions in spring samples. The annual loads of $\mathrm{Ca}$ and $\mathrm{Mg}$ discharged from springs such as Miller Spring represent dissolution of a substantial mass of bedrock, indicating a dynamic karst system that is continually developing. For example, assuming (1) all $\mathrm{Ca}$ in water samples from Shanghai Spring is derived from dissolution of dolomite, (2) a daily mean discharge of $18 \mathrm{ft}^{3} / \mathrm{s}$, and (3) an average Ca concentration of $38 \mathrm{mg} / \mathrm{L}$, the yearly mass of Ca discharged by Shanghai Spring represents the dissolution of about
$35,000 \mathrm{ft}^{3}$ (cubic feet) of bedrock equivalent to a cubic cavern with dimensions of $33 \mathrm{ft}$ per side. This constant dissolution of material over many thousands of years has manifested itself in the extensive dissolution and collapse features observed within the lower part of the Roubidoux Formation.

Boxplots showing the distribution of selected physical properties, chemical constituents, and ion ratios in samples from ground water, springs, and major streams and tributaries at the FLWMR are shown in figure 26. Background concentrations of major and trace inorganic constituents in spring samples generally were smaller than concentrations detected in ground-water samples from wells (table 25; fig. 26). Specific conductance values and concentrations of inorganic constituents in spring water samples generally were larger in low-base flow samples than in high-base flow samples (table 22), reflecting dilution by increased local recharge during high-base flow conditions.

Water samples from Shanghai Spring and the pumping station spring had probable effects of septic contamination. The high- and low-base flow samples from Shanghai Spring contained larger than background concentrations of $\mathrm{Na}(7.0 \mathrm{mg} / \mathrm{L}), \mathrm{Na}_{\mathrm{t}}(7.1$ and $7.2 \mathrm{mg} / \mathrm{L}), \mathrm{Cl}(9.6$ and $8.5 \mathrm{mg} / \mathrm{L}), \mathrm{NO}_{2}+\mathrm{NO}_{3 \mathrm{t}}(1.4$ and $2.0 \mathrm{mg} / \mathrm{L}), \mathrm{P}_{\mathrm{t}}(0.07$ and $0.38 \mathrm{mg} / \mathrm{L}), \mathrm{B}(32$ and 30 $\mu \mathrm{g} / \mathrm{L})$, and $B_{t}(30$ and $40 \mu \mathrm{g} / \mathrm{L})$. The high-base flow sample also contained larger than background concentrations of $\mathrm{SO}_{4}(10 \mathrm{mg} / \mathrm{L})$ and $\mathrm{NH}_{3}(0.05 \mathrm{mg} / \mathrm{L})$. The low-base flow sample also contained larger than background specific conductance values $(434 \mu \mathrm{S} / \mathrm{cm})$ and concentrations of $\mathrm{K}(2.3 \mathrm{mg} / \mathrm{L})$. The low-base flow sample from the pumping station spring contained larger than background $\mathrm{Na}(3.1 \mathrm{mg} / \mathrm{L}), \mathrm{Na}_{\mathrm{t}}(3.2 \mathrm{mg} / \mathrm{L})$, $\mathrm{Cl}(6.4 \mathrm{mg} / \mathrm{L})$, and $\mathrm{NO}_{2}+\mathrm{NO}_{3 \mathrm{t}}(0.88 \mathrm{mg} / \mathrm{L})$ concentrations. The high-base flow sample from the pumping station spring contained only TOC ( $36 \mathrm{mg} / \mathrm{L})$ concentrations larger than background. A historical dye-trace test (fig. 7, trace HT-03; Harvey, 1980) verified a subsurface connection between Shanghai Spring and Dry Creek, which contains the sewage treatment plant. Effluent from the plant is a likely source of the larger than background constituent concentrations in Shanghai Spring. The pumping station spring is downgradient of a residential area, and runoff through storm sewers or leakage from sanitary or combined storm and sanitary sewers is a likely source of the larger than background constituent concentrations. 


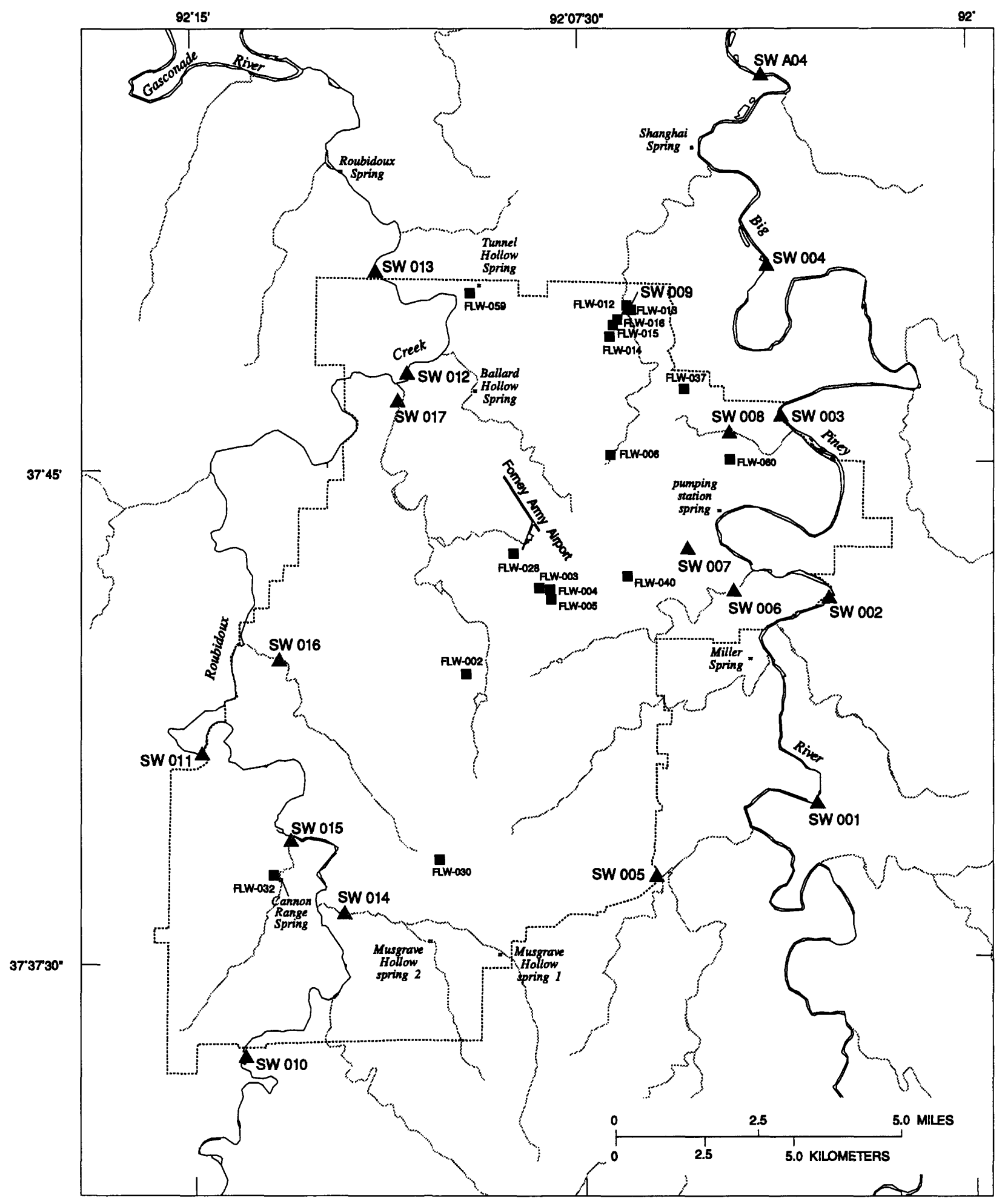

\section{EXPLANATION}

FORT LEONARD WOOD MILTTARY RESERVATION

$\triangle$ SW 014 SPRING, SURFACE-WATER, OR STREAMBED SEDIMENT

SAMPLE SITE AND IDENTIFIER

- FW-002 SOUD-WASTE MANAGEMENT UNIT AND IDENTIFIER

Figure 24. Location of spring, surface-water, or streambed sediment sample sites at the Big Piney River, Roubidoux Creek, and tributaries and contributing springs at and near the Fort Leonard Wood Military Reservation. 


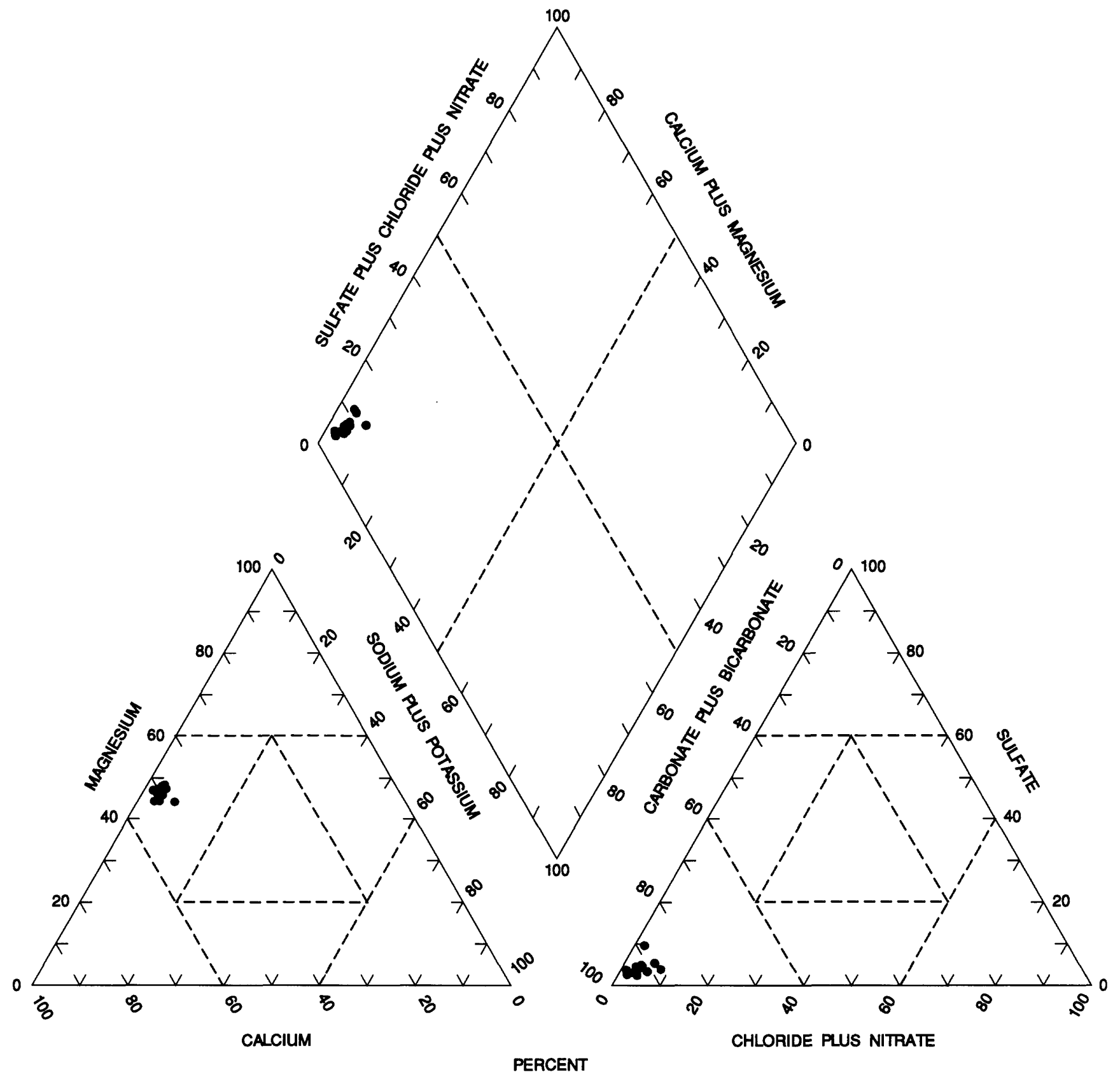

NORMAUZED MILEQUIVALENTS OF MANOR IONS

\section{EXPLANATION}

- SPRING SAMPLING SITES INCLUDE:

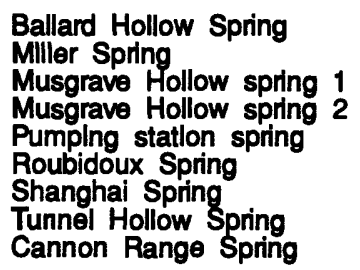

Fgure 25. Trilinear diagram depicting relative concentrations of major cations and anions in spring samples. 
Geochemical modeling indicates the water quality of Shanghai Spring can be simulated by mixing uncontaminated spring water with the flow lost from Dry Creek. A simple mixing model was developed using the geochemical code PHREEQE (Parkhurst and others, 1980). Because Miller Spring and Shanghai Spring are located in similar geologic settings and had identical low-base flow discharges $\left(26 \mathrm{ft}^{3} / \mathrm{s}\right)$, waterquality data from Miller Spring were used to represent the uncontaminated component of flow in the model. Measured discharges and constituent concentrations in the high-base flow sample from Dry Creek (table 23, site SW 009) and the low-base flow sample from Miller Spring (table 22) were used in the model. A constant volume mixing scenario was used, and equilibrium with calcite and a partial pressure of carbon dioxide $\left(\mathrm{CO}_{2}\right)$ of $1 \times 10^{-2.3}$ atmospheres were assumed. Results of the modeling indicate that all of the flow lost in Dry Creek probably emerges at Shanghai Spring (table 26).

Spring samples contained various densities of fecal coliform [0 to $810 \mathrm{col} / 100 \mathrm{~mL}$ (colonies per 100 $\mathrm{mL}$ )] and fecal streptococcus bacteria (0 to 360 col/100 mL; table 22). Most of the results involved non-ideal colony counts. The sample from Ballard Hollow Spring contained among the largest densities of fecal coliform (150 col $/ 100 \mathrm{~mL})$ and fecal streptococcus $(360 \mathrm{col} / 100 \mathrm{~mL})$ bacteria within the ideal count range (table 22). The ratio of fecal coliform to fecal streptococcus bacteria in this sample is 2.4. A fecal coliform to fecal streptococcus bacteria ratio greater than 4.1 generally is indicative of human waste and ratios less than 0.7 are indicative of animal waste (American Public Health Association and others, 1985). Ratios between 0.7 and 4.4 generally are interpreted as mixed human-animal wastes; however, ratios from sampling points more than 24 hours downstream from the source may be unreliable because fecal streptococcus bacteria have a relatively short life span outside their animal host. A possible source of the bacterial contamination to Ballard Hollow Spring is the FLWMR horse stable located about $1 \mathrm{mi}$ east of Ballard Hollow Spring. The mixed human-animal waste signature (ratio of 2.4) could indicate that the travel time from the source to Ballard Hollow Spring is greater than 24 hours.

Water samples from Shanghai Spring contained detectable concentrations of VOCs (table 24). Tetrachloroethene (PCE; 1.5 and $0.8 \mu \mathrm{g} / \mathrm{L}$ ) and trichloromethane (less than or equal to $0.2 \mu \mathrm{g} / \mathrm{L}$ ) were detected in the high- and low-base flow samples from Shanghai Spring. The trace concentration $(0.2 \mu \mathrm{g} / \mathrm{L})$ of trichloromethane detected in the high-base flow sample, however, may be related to contamination from the $\mathrm{HCl}$ preservative because chloromethane, a known preservative contaminant, also was detected in this sample. The concentrations of PCE may be biased low. Water discharged from Shanghai Spring flows through a cave system at least several hundred feet before reaching the spring orifice (Vineyard and Feder, 1974). Because of its large Henry's law constant of $1.46 \times 10^{-2}$ atmospheres-cubic meter per mole (Montgomery, 1991), PCE would quickly volatilize once water enters the cave system. Concentrations in water samples collected downgradient from the spring orifice probably are smaller than those in water entering the cave system. Assuming an average PCE concentration of $1.2 \mu \mathrm{g} / \mathrm{L}$ and a daily mean discharge of 18 $\mathrm{ft}^{3} / \mathrm{s}$ (Vineyard and Feder, 1974), about $19 \mathrm{~kg}$ (kilograms), or 3 gal, of PCE is discharged per year from Shanghai Spring.

At least one known and two potential sources of PCE contamination are known at the FLWMR: SWMU FLW-002 located about $2.5 \mathrm{mi}$ southwest of Forney Army Airport and a dry-cleaning shop and float yard storage area (fig. 1). Samples collected by the USGS from monitoring wells at SWMU FLW-002 contained PCE concentrations (less than 0.2 to 4.7 $\mu \mathrm{g} / \mathrm{L}$ ) close to the MDNR MCL of $5 \mu \mathrm{g} / \mathrm{L}$. The SWMU FLW-002 is about $1.5 \mathrm{mi}$ south of a dye-injection point where dye concentrations were detected at Shanghai Spring and about $1.2 \mathrm{mi}$ southeast of a dyeinjection point where dye concentrations were detected at Miller Spring. Because no dye-trace tests have been conducted in the immediate vicinity of SWMU FLW-002, conduit ground-water flow from that site to Shanghai Spring cannot be eliminated from consideration. Wastes containing PCE from the drycleaning shop temporarily were stored in the float yard located within the cantonment area about $3.5 \mathrm{mi}$ southwest of Shanghai Spring (fig. 24). This area is within the probable catchment area of Shanghai Spring as defined by dye-trace tests (fig. 16). Two shallow (less than $2 \mathrm{ft}$ deep) soil samples collected in 1992 during an investigation of the float yard (Radian Corporation, 1993) contained PCE; however, concentrations were less than the method reporting level of 2 $\mu \mathrm{g} / \mathrm{kg}$ (micrograms per kilogram). No subsurface samples were collected, and only four surficial samples were analyzed for PCE. An outside storage pad and 

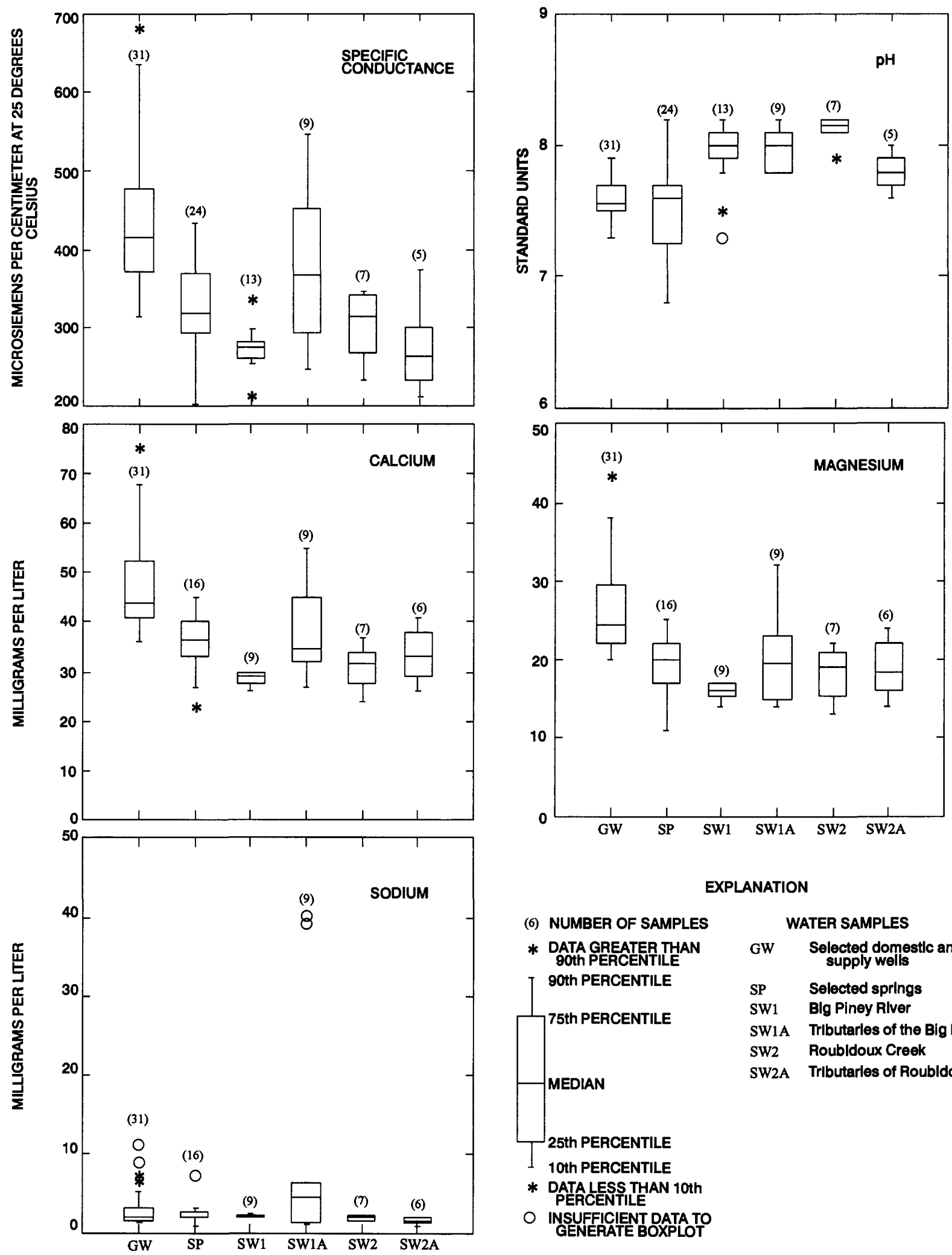

EXPLANATION

(6) NUMBER OF SAMPLES

* data greater than 90th PERCENTILE T 90th PERCENTILE 75th PERCENTILE<smiles>CCCC</smiles>

MEDIAN

25th PERCENTILE

10th PERCENTILE

* DATA LESSTHAN 10th

O INSUFFICIENT DATA TO
WATER SAMPLES

GW Selected domestic and publlcsupply wells

SP Selected springs SW1 BIg Piney Rlver SW1A Trlbutarles of the Big PIney River SW2 Roubldoux Creek SW2A Trlbutarles of Roubldoux Creek

Figure 26. Boxplots of selected physical properties and chemical constituents in water samples from wells, springs, and major streams and tributaries at the Fort Leonard Wood Military Reservation. 

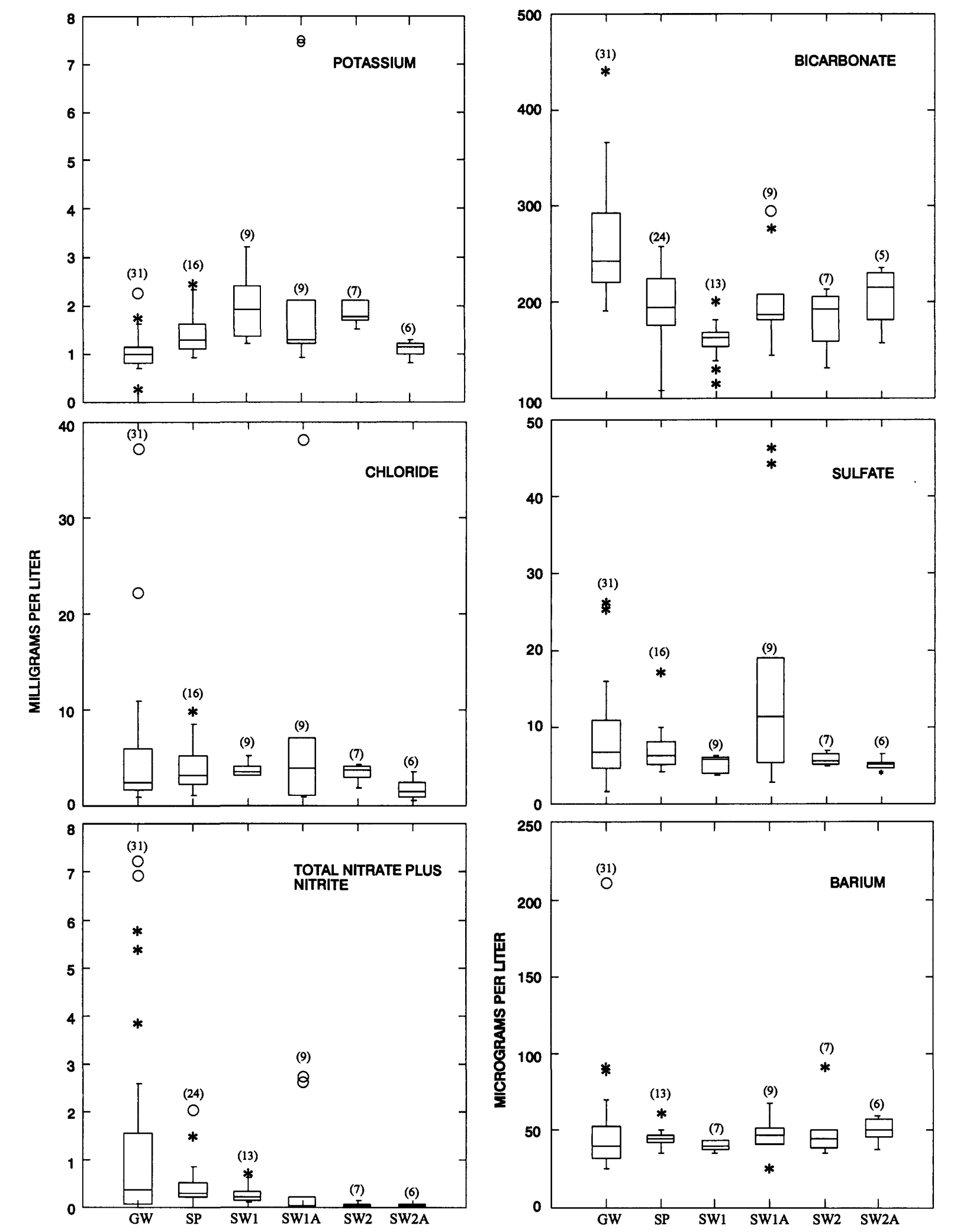

Figure 26. Boxplots of selected physical propertles and chemlcal constituents In water samples from weils, springs, and major streams and tributaries at the Fort Leonard Wood Military Reservation-Continued. 

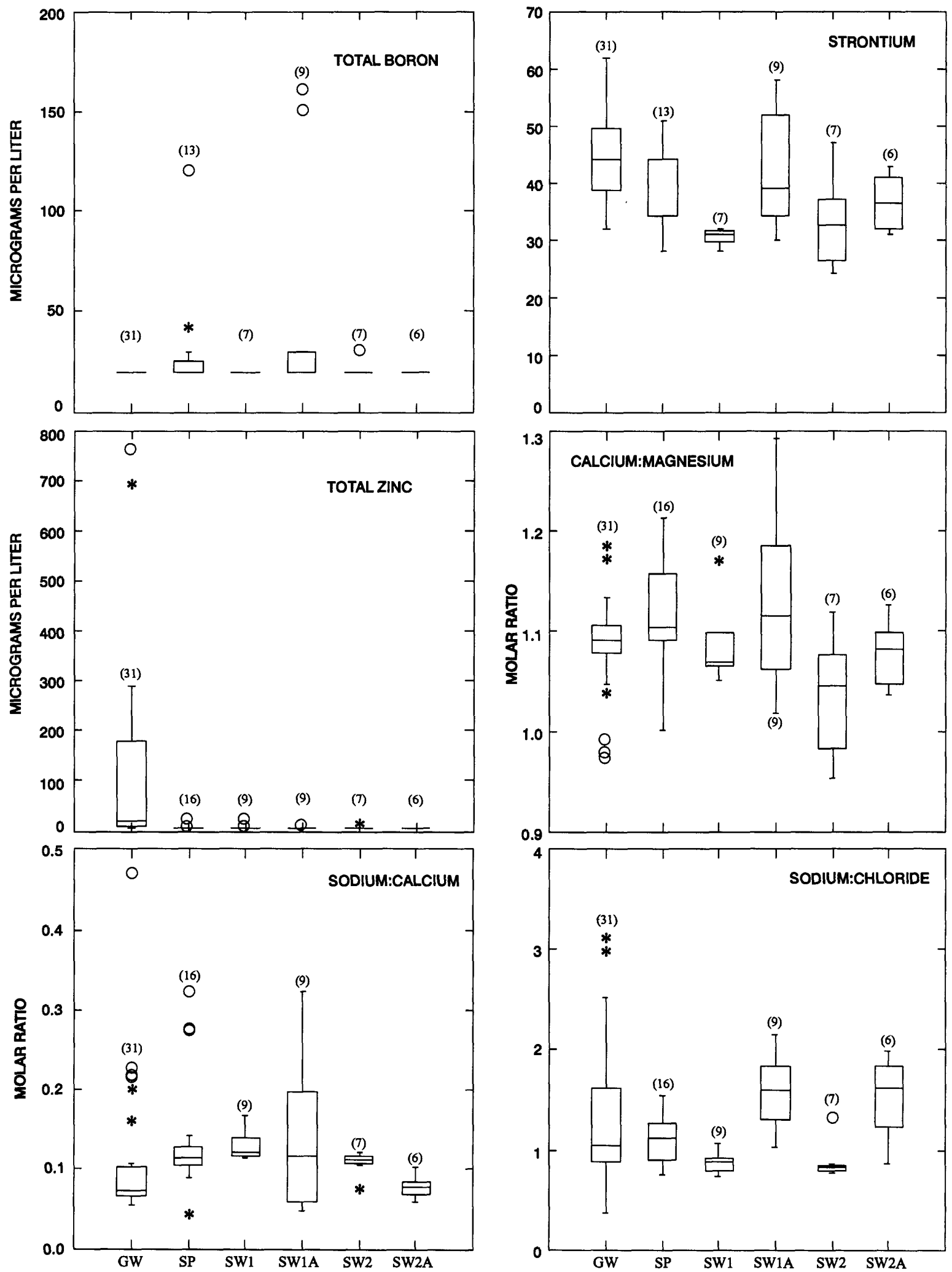

Figure 26. Boxplots of selected physlcal propertles and chemlcal constltuents in water samples from wells, springs, and major streams and tributaries at the Fort Leonard Wood Military Reservation-Continued. 
Table 26. Simulation of water quality at Shanghai Spring

[na, not applicable; mg/L, milligrams per liter; $\mu \mathrm{g} / \mathrm{L}$, micrograms per liter]

\begin{tabular}{lcccc}
\hline \multicolumn{1}{c}{ Descriptor } & $\begin{array}{c}\text { MIller Spring } \\
\mathbf{0 8 - 1 4 - 9 5}\end{array}$ & $\begin{array}{c}\text { Dry Creek } \\
\text { 06-13-95 }\end{array}$ & $\begin{array}{c}\text { Shanghal Spring } \\
\text { 08-15-95 }\end{array}$ & $\begin{array}{c}\text { Simulated Shanghal } \\
\text { Spring }^{2}\end{array}$ \\
\hline Flow component (percent) & 83 & 17 & na & na \\
pH & 7.6 & 7.8 & 7.7 & 7.6 \\
Temperature (degrees Celsius) & 13.5 & 21.5 & 15.5 & 14.9 \\
Calcium, dissolved (mg/L) & 38 & 32 & 45 & 46 \\
Magnesium, dissolved (mg/L) & 21 & 15 & 25 & 20 \\
Sodium, dissolved (mg/L) & 2.0 & 39 & 7.0 & 8.3 \\
Potassium (mg/L) & 1.2 & 7.4 & 2.4 & 2.3 \\
Bicarbonate (mg/L) & 195 & 182 & 257 & 235 \\
Sulfate (mg/L) & 5.1 & 46 & 9.1 & 12.1 \\
Chloride (mg/L) & 2.3 & 38 & 8.5 & 8.5 \\
Nitrate plus nitrate as nitrogen, total $(\mathrm{mg} / \mathrm{L})$ & .36 & 2.7 & 2.0 & 2.2 \\
Strontium $(\mu \mathrm{Lg} / \mathrm{L})$ & 38 & 52 & 47 & 40 \\
\hline
\end{tabular}

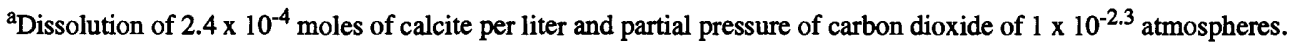

drain lines leading from the building containing the dry-cleaning shop and the float yard are possible PCE sources. Other potential sources include several other closed SWMUs (FLW-006, FLW-012, FLW-013, FLW-014, FLW-015, and FLW-016) within the Shanghai Spring probable catchment area that have not yet been investigated.

High-base flow samples from the pumping station spring and Shanghai Spring contained detectable concentrations of the pesticides prometon ( 7 and 8 $\mathrm{ng} / \mathrm{L})$ and simazine $(8$ and $6 \mu \mathrm{g} / \mathrm{L})$. Prometon is a nonselective herbicide used for the control of many weeds and grasses (Meister Publishing Company, 1994). Simazine is a selective herbicide commonly used on crops such as corn and alfalfa, and on turf grasses. The absence of these pesticides from other springs at and near the FLWMR indicates they probably are, or were, used in the residential and industrial areas within the catchment areas of these springs. None of the spring samples contained detectable quantities of semivolatile organic compounds or XACs.

\section{Surface-Water Quality}

During this investigation, the USGS collected 32 water-quality samples (including 4 duplicate sam- ples) from 17 surface-water sites at and near the FLWMR between April 1 and October 10, 1995 (fig. 24). Water samples were collected from the Big Piney River and Roubidoux Creek upstream (sites SW 001 and SW 010) and downstream (sites SW 004 and SW 013) from the FLWMR (fig. 24). In addition, water samples were collected from sites on the Big Piney River (sites SW 002 and SW 003) and Roubidoux Creek (sites SW 011 and SW 012) and near the mouth of tributaries draining the FLWMR. Data from seven water-quality samples (including one duplicate sample) collected from the Big Piney River near Devils Elbow (site SW A04, fig. 24) downstream from the FLWMR as part of the USGS ambient water-quality monitoring program also were included. Surface-water samples also were collected during high- and low-base flow conditions. High-base flow samples were collected during April and June 1995 and low-base flow samples were collected during August and October 1995 (table 23). Samples from the Big Piney River and Roubidoux Creek were analyzed for dissolved and total major and trace inorganic constituents, VOCs, semivolatile organic compounds, pesticides (high-base flow only), and XACs (high-base flow only). Samples from tributary sites were analyzed for dissolved and total major and trace inorganic constituents, VOCs, 
semivolatile organic compound scan by GC-FID, pesticides (high-base flow only), and XACs (high-base flow only).

Despite large differences in discharge and drainage basin size, samples from surface-water sites (excluding samples from site SW 009) generally had similar values of physical properties and inorganic constituents. Because of the similar water quality at most of the surface-water sites, generally data from all sites except site SW 009 were used to calculate background values for surface water. Background values of physical properties and concentrations of inorganic chemical constituents were calculated using an interpretative process similar to that used for ground-water and spring samples and are listed in table 25 .

Surface-water samples generally had specific conductance values less than about $350 \mu \mathrm{S} / \mathrm{cm}$ and $\mathrm{Ca}$, $\mathrm{Mg}$, and $\mathrm{HCO}_{3}$ as the major ions. Samples from surface-water sites, except those from sites SW 007, SW 008, and SW 009, plot in a group near the $\mathrm{Ca}, \mathrm{Mg}$ $\mathrm{HCO}_{3}$ vertex on a trilinear diagram (fig. 27). Samples from site SW 007 contained larger than background concentrations of $\mathrm{Na}(4.2$ and $6.3 \mathrm{mg} / \mathrm{L}), \mathrm{Na}_{\mathrm{t}}(4.3$ and $6.1 \mathrm{mg} / \mathrm{L})$, and $\mathrm{SO}_{4}(13$ and $19 \mathrm{mg} / \mathrm{L})$. This site is on a tributary stream that flows into the Big Piney River about 0.25 river mi downstream from the FLWMR water-treatment plant. The plant uses aluminum sulfate $\left[\mathrm{Al}_{2}\left(\mathrm{SO}_{4}\right)_{3}\right]$ and sodium hydroxide $(\mathrm{NaOH})$ during the treatment process, and overflow from the plant is a possible source of the increased $\mathrm{Na}$ and $\mathrm{SO}_{4}$ concentrations in these samples. Samples from site SW 008 contained larger than background values of specific conductance (399 and $452 \mu \mathrm{S} / \mathrm{cm}$ ) and concentrations of $\mathrm{Ca}$ (45 and $55 \mathrm{mg} / \mathrm{L}), \mathrm{Ca}_{\mathrm{t}}(42$ and $53 \mathrm{mg} / \mathrm{L}$ ), $\mathrm{Mg}$ (23 and $32 \mathrm{mg} / \mathrm{L}), \mathrm{Mg}_{\mathrm{t}}(31 \mathrm{mg} / \mathrm{L}$ in one sample), $\mathrm{Na}$ (4.7 and $4.9 \mathrm{mg} / \mathrm{L}), \mathrm{Na}_{\mathrm{t}}(4.7 \mathrm{mg} / \mathrm{L}), \mathrm{HCO}_{3}(275$ $\mathrm{mg} / \mathrm{L}$ in one sample), $\mathrm{SO}_{4}(17$ and $9.8 \mathrm{mg} / \mathrm{L}), \mathrm{Cl}(7.0$ and $5.8 \mathrm{mg} / \mathrm{L}), \mathrm{B}(37 \mu \mathrm{g} / \mathrm{L}$ in one sample $), \mathrm{B}_{\mathrm{t}}(30$ $\mu \mathrm{g} / \mathrm{L})$, and $\operatorname{Sr}(54$ and $58 \mu \mathrm{g} / \mathrm{L})$. The source of the larger than background concentrations is uncertain; however, the lack of increased concentrations of nutrients indicates the source is not sewage or septic effluent. This tributary drains a large part of the cantonment area and may be affected by runoff from a number of industrial facilities, a closed landfill $0.5-\mathrm{mi}$ upstream, or runoff from residential areas within the basin. The discharge at site SW 009 during the highbase flow sampling was composed almost entirely of effluent from the sewage treatment plant (about 1,500 $\mathrm{ft}$ upstream) and, consequently, the water quality is substantially degraded. The high-base flow sample had larger than background values of specific conductance $(548 \mu \mathrm{S} / \mathrm{cm})$ and concentrations of $\mathrm{Na}(39$ $\mathrm{mg} / \mathrm{L}), \mathrm{Na}_{\mathrm{t}}(38 \mathrm{mg} / \mathrm{L}), \mathrm{K}(7.4 \mathrm{mg} / \mathrm{L}), \mathrm{SO}_{4}(44 \mathrm{mg} / \mathrm{L})$, $\mathrm{Cl}(38 \mathrm{mg} / \mathrm{L}), \mathrm{F}(0.7 \mathrm{mg} / \mathrm{L})$, dissolved solids (286 $\mathrm{mg} / \mathrm{L}), \mathrm{TOC}(7.7 \mathrm{mg} / \mathrm{L}), \mathrm{NO}_{2}+\mathrm{NO}_{3 \mathrm{t}}(2.7 \mathrm{mg} / \mathrm{L}), \mathrm{NO}_{2 \mathrm{t}}$ $(0.26 \mathrm{mg} / \mathrm{L}), \mathrm{NH}_{3}(8.4 \mathrm{mg} / \mathrm{L}), \mathrm{P}_{\mathrm{t}}(1.5 \mathrm{mg} / \mathrm{L}), \mathrm{B}(140$ $\mu \mathrm{g} / \mathrm{L}), \mathrm{B}_{\mathrm{t}}(150 \mu \mathrm{g} / \mathrm{L})$, and $\operatorname{Sr}(52 \mu \mathrm{g} / \mathrm{L})$. During the low-base flow sampling, effluent from the sewage treatment plant was lost to the subsurface before it reached site SW 009.

Generally, concentrations of major inorganic constituents and nutrients had an inverse relation with discharge; the smallest discharges and the largest constituent concentrations generally occurred during the low-base flow sampling. This inverse relation is caused by the decreased proportion of low ionicstrength precipitation/runoff during low-base flow conditions. Samples from the Big Piney River at site SW 001, however, did not follow this trend, and concentrations of most major inorganic constituents and nutrients, except for $\mathrm{K}$, silica $\left(\mathrm{SiO}_{2}\right)$, and $\mathrm{NO}_{2}+\mathrm{NO}_{3 \mathrm{t}}$, were smaller in the low-base flow sampling. Although the low-base flow discharge $\left(292 \mathrm{ft}^{3} / \mathrm{s}\right)$ was smaller than the high-base flow discharge $\left(441 \mathrm{ft}^{3} / \mathrm{s}\right)$, the lowbase flow sample was collected on the receding limb of a small rise caused by rainfall several days before sample collection. Specific conductance values and most constituent concentrations were, therefore, diluted by rainfall runoff. The larger $\mathrm{K}, \mathrm{SiO}_{2}$, and $\mathrm{NO}_{2}+\mathrm{NO}_{3 \mathrm{t}}$ concentrations in the low-base flow sample from site SW 001 may be caused by leaching of $\mathrm{K}$ and $\mathrm{NO}_{2}+\mathrm{NO}_{3 \mathrm{t}}$ from soils or plant matter. Hem (1992) noted that during periods of relatively high discharge, $\mathrm{K}$ concentrations in streams from the central United States were nearly as large or larger during times of high discharge as during low discharge and attributed this to leaching of $\mathrm{K}$ from soil and organic material by runoff.

None of the surface-water samples contained detectable concentrations of VOCs, semivolatile organic compounds, or XACs; however, high-base flow samples from the Big Piney River (sites SW 001, SW 002, SW 003, and SW 004) and tributary site SW 008 contained several pesticides (table 24). Tebuthiuron was detected in samples from site SW 001 ( 9 $\mathrm{ng} / \mathrm{L})$, site SW 002 (8 ng/L), and site SW 003 (9 ng/L). The detection of this herbicide in the upstream sample (site SW 001) and similar concentrations in the samples from sites SW 002 and SW 003 indicate sources 


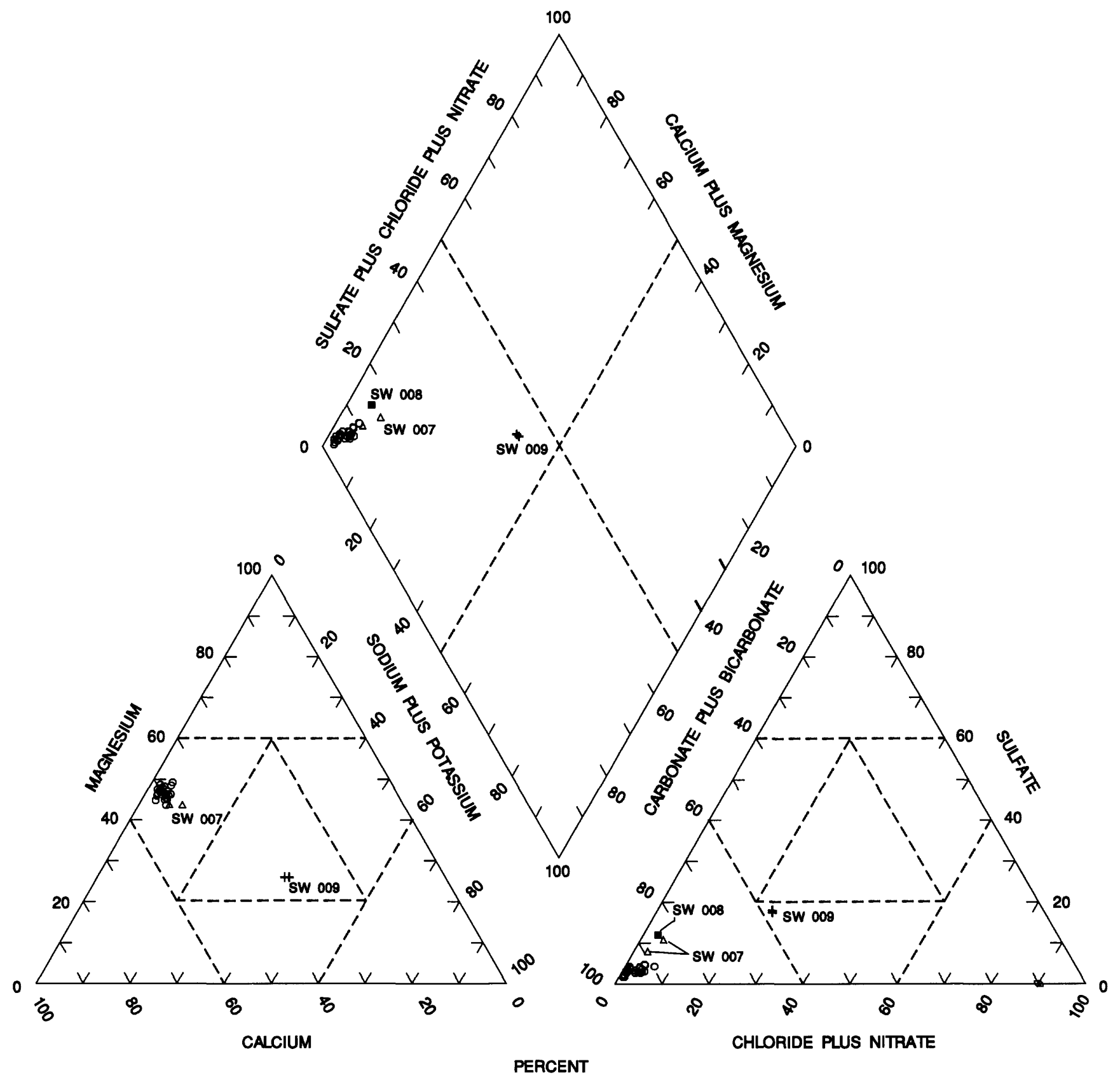

NORMAUZED MIUEQUIVALENTS OF MANOR IONS

EXPLANATION

- SURFACE-WATER SITE

$\triangle$ SW 007

- SW 008

+ SW 009

Figure 27. Trilinear diagram depicting relative concentrations of major cations and anions in surface-water samples. 
other than the FLWMR. Atrazine was detected in the sample from site SW $002(2 \mathrm{ng} / \mathrm{L})$ and an atrazine metabolite, deethylatrazine, was detected in samples from sites SW 002 and SW 004 (4 ng/L). Atrazine is a widely used selective herbicide commonly applied in the spring on row crops such as corn, and widespread occurrence of atrazine in streams in the central United States has been attributed to runoff from agricultural areas (Goolsby and others, 1991). Several corn fields along the Big Piney River in the vicinity of site SW 002 are a possible source of the atrazine detected. The sample from tributary site SW 008 contained $p, p$ 'DDE at the reporting level of $1 \mathrm{ng} / \mathrm{L}$. The SWMU FLW-037, the old pesticide building where pesticides were mixed and stored at the FLWMR, is located about 0.5 mi upstream from site SW 008. Large concentrations of DDT and other organochlorine pesticides have been detected in soils adjacent to the SWMU FLW-037 (U.S. Army Environmental Hygiene Agency, 1992). In 1995, the USGS detected $p, p^{\prime}$-DDE, DDT, chlordane, and dieldrin in streambed sediment samples between the SWMU FLW-037 and site SW 008 (data on file at the USGS, Rolla, Missouri).

\section{Streambed Sediment Quality}

Streambed sediment samples were collected from Big Piney River and Roubidoux Creek upstream (sites SW 001 and SW 010) and downstream (SW 004 and SW 013) from the FLWMR (fig. 24). Initially, these samples were analyzed for grain size, concentrations of major and trace inorganic constituents, chlorophenoxy-acid herbicides, chlorinated organic compounds, XACs, dioxin, and furans. Analytical results of subsamples submitted for grain size, trace element, and chlorinated organic compounds had not been received at the time of this report. None of the samples contained detectable concentrations of chlorophenoxy-acid herbicides or XACs. Small concentrations of octachlorodibenzoparadioxin (OCDD) were detected in streambed sediment samples from sites SW $001(0.21 \mu \mathrm{g} / \mathrm{kg})$ and SW $004(0.01 \mu \mathrm{g} / \mathrm{kg})$. Small concentrations of OCDD are common because this compound can be produced as a natural combustion product.

\section{SUMMARY AND CONCLUSIONS}

A geohydrologic and water-quality assessment of the Fort Leonard Wood Military Reservation has increased the knowledge of geologic controls on regional ground-water flow in the karst terrane at the Fort Leonard Wood Military Reservation, has provided background water-quality data for ground- and surface-water resources at the Fort Leonard Wood Military Reservation, and has identified the presence of organic compound contamination in Shanghai Spring, a major discharge point for ground water flowing from the Fort Leonard Wood Military Reservation and adjacent areas to the north. Geologic mapping of the southern Fort Leonard Wood Military Reservation area resulted in identification of an extension of the Countyline Fault through the southern Fort Leonard Wood Military Reservation and the presence of two intersecting smaller faults, a probable extension of Nelson Creek Fault and a new fault named Hurd Hollow Fault. One geologic observation of hydrologic interest was structural evidence for substantial dissolution of interbedded dolostone in the lower part of the Roubidoux Formation and collapse of overlying sandstone-rich strata. The zones of dissolution along bedding planes offer large permeability pathways for ground-water flow. A conclusion derived from observations of hundreds of fractures at the Fort Leonard Wood Military Reservation is that fractures commonly do not extend through the full thickness of formations, and most fractures do not show evidence of solution activity.

Ground-water levels and general directions of ground-water flow beneath the Fort Leonard Wood Military Reservation are similar under conditions of high-base and low-base flow. Ground-water levels in the central part of the Fort Leonard Wood Military Reservation show characteristics associated with substantial karst development. Ground water that normally would have flowed westward to Roubidoux Creek is redirected eastward to the Big Piney River by zones of large secondary permeability, and ground water that would have flowed eastward to the Big Piney River is redirected more northward toward Shanghai Spring. The regional ground-water divide in this area is as much as 2 miles west of the regional topographic divide. Water levels in the southern Fort Leonard Wood Military Reservation area generally are higher along the major recharge areas on topographic ridges and lower at discharge areas in the major river valleys. Ground-water flow is nearly perpendicular to 
the regional streams. Vertical ground-water flow generally is downward from the Gasconade Dolomite to the Potosi Dolomite, but may be upward in areas of highly permeable karst terrane where ground-water levels in the Roubidoux Formation and Gasconade Dolomite are lowered because of rapid flow of ground water through conduits to nearby springs.

Dye-trace tests, used to investigate groundwater flow from distinct recharge points (such as sinkholes) to discharge points (such as springs), were used to determine ground-water flow directions and rates in the karst terrane at the Fort Leonard Wood Military Reservation and to determine catchment areas for several springs. The catchment area of Shanghai Spring includes a substantial part of the north-central and northeastern Fort Leonard Wood Military Reservation. Miller Spring receives water from much of the eastcentral part of the Fort Leonard Wood Military Reservation. The boundary location between Shanghai Spring and Miller Spring catchment areas has been narrowed, but further investigations would be necessary to delineate this boundary.

A series of stream-discharge measurements, or seepage-run measurements, made on the Big Piney River and Roubidoux Creek during high-base and low-base flow conditions were analyzed to determine ground-water discharge through their streambeds. Stream-discharge data for the Big Piney River indicate that the river loses water from about 30 to 38 river miles above its mouth, gains water from about 18 to 30 river miles above its mouth, and loses water from about 18 river miles above its mouth to near its mouth. However, the uncertainty in these measurements and the small magnitude of apparent ground-water inflow make a definitive conclusion impossible. Data from streamflow measurements indicate that Roubidoux Creek gains water from 28 to about 34 river miles above its mouth. During high-base flow conditions, the entire flow of Roubidoux Creek is lost 22 miles above its mouth. During low-base flow conditions, the entire flow is lost 24 miles above the mouth. This flow loss is associated with the intersection of Roubidoux Creek, the Countyline Fault, and Hurd Hollow Fault. Measurements made on about the lower 8 river miles of Roubidoux Creek indicate that essentially all flow in this reach of the creek is derived from tributary stream or spring inflow. During all but the highest flow conditions, Roubidoux Creek is dry throughout a 7- to 8-river mile reach along the western boundary of the Fort Leonard Wood Military Reservation.
Water-quality samples collected from regional ground-water and surface-water sources during highbase and low-base flow conditions were used to establish baseline water-quality conditions at the Fort Leonard Wood Military Reservation. No obvious difference was detected in water quality between samples collected during high- and low-base flow conditions. Ground-water quality at the Fort Leonard Wood Military Reservation is similar to the regional water quality of the Ozark aquifer, a calcium magnesium bicarbonate type water with concentrations of chloride and sulfate less than 10 milligrams per liter; dissolved solids concentrations generally were less than 300 milligrams per liter. Ground-water specific conductance values ranged from 315 to 680 microsiemens per centimeter, $\mathrm{pH}$ was about 7.5 , and calcium, magnesium, and bicarbonate were the predominant ions. Major and trace elements concentrations in well samples were used to establish background concentrations for ground water at the Fort Leonard Wood Military Reservation. Concentrations of most trace elements in ground-water samples generally were less than detection limits or less than a few tens of micrograms per liter except for barium, total barium, total iron, strontium, zinc, and total zinc. Thirteen ground-water samples contained large (68 to 760 micrograms per liter) concentrations of dissolved zinc or total zinc. The most likely source for the increased zinc and total zinc concentrations is the corrosion of galvanized pipes used in many domestic and public-water-supply wells.

Samples from six wells contained small (less than 1.6 micrograms per liter) concentrations of trihalomethane compounds, such as chloromethane, trichloromethane, bromomethane, bromodichloromethane, dibromochloromethane, and bromoform, that probably are the result of chlorination of the wells or contaminated hydrochloric acid used to preserve some samples. Only three ground-water samples contained detectable concentrations of volatile organic compounds other than trihalomethane compounds; one sample contained total xylenes concentrations of 0.3 microgram per liter, and two samples contained methyltertiarybutylether concentrations of 0.3 and 0.6 microgram per liter. One or more of the non-target volatile organic compounds dibromomethylbenzene, 1bromo-3,5-dimethylbenzene, 4-bromo-1,2-dimethylbenzene, cyanogen chloride, 2-methylpropanal, pentanal, and 2,4-dimethyl heptane were tentatively identified in samples from three wells. No semivolatile organic compounds or explosives associated com- 
pounds were detected in any ground-water samples. The pesticides diazinon, $p, p^{\prime}-\mathrm{DDE}$ (a degradation product of DDT), or tebuthiuron was detected in samples from four wells. The results of ground-water sampling indicate that much of the shallow ground water in the Fort Leonard Wood Military Reservation is susceptible to contamination from surficial sources.

Water-quality samples were collected from eight springs during high-base flow and six springs during low-base flow at the Fort Leonard Wood Military Reservation. Spring water had specific conductance values ranging from 203 to 434 microsiemens per centimeter, $\mathrm{pH}$ values of about 7.5, and calcium, magnesium, and bicarbonate as the principal ions. Dissolution of dolomite is the principal source of major ions in spring samples; annual calcium and magnesium loads at major springs represent dissolution of a substantial rock mass. Background concentrations of major and trace inorganic constituents in spring samples generally were smaller than concentrations detected in ground-water samples from wells. Specific conductance values and concentrations of inorganic constituents generally were larger in spring-water samples collected during low-base flow, reflecting dilution by increased local recharge during high-base flow conditions. Samples from two springs, Shanghai Spring and the pumping station spring, exhibit probable effects of septic contamination. Results of geochemical modeling indicate that all of the flow lost in Dry Creek probably emerges at Shanghai Spring. Fecal coliform and fecal streptococcus bacteria densities varied in spring water; among the largest densities were detected in the sample from Ballard Hollow Spring, the source of which may possibly be the Fort Leonard Wood Military Reservation horse stable located about 1 mile east of Ballard Hollow Spring. Water samples from Shanghai Spring contained detectable concentrations of trichloromethane (possibly a preservative contaminant) and concentrations of tetrachloroethene equivalent to a discharge of 3 gallons of tetrachloroethene per year. High-base flow samples from the pumping station spring and Shanghai Spring contained detectable concentrations of the pesticides prometon and simazine.

Water samples collected from 17 surface-water sites at the Fort Leonard Wood Military Reservation during high- and low-base flow conditions generally (excluding samples from site SW 009) had similar values of physical properties and concentrations of inorganic constituents. Surface-water samples generally had specific conductance values less than about 350 microsiemens per centimeter and calcium, magnesium, and bicarbonate as the major ions. Concentrations of major inorganic constituents and nutrients typically had an inverse relation with discharge, except for one sample collected from the Big Piney River, where the concentrations probably were diluted by runoff. No surface-water samples contained detectable concentrations of volatile, semivolatile organic compounds, or explosives associated compounds; however, samples from the Big Piney River and a tributary contained the pesticides tebuthiuron, atrazine, deethylatrazine, and $p, p^{\prime}-\mathrm{DDE}$.

Analytical results of streambed sediment samples collected from Big Piney River and Roubidoux Creek for grain size, trace element and chlorinated organics analysis are not yet available. No samples contained detectable concentrations of chlorophenoxy-acid herbicides or explosives associated compounds. Small concentrations of octachlorodibenzoparadioxin, a natural combustion product, were detected in bed sediment samples from two sites.

\section{SELECTED REFERENCES}

American Public Health Association and others, 1985, Standard methods for the examination of water and wastewater (16th ed.): Washington, D.C., American Public Health Association, 1,268 p.

American Society for Testing Materials, 1984, 1984 annual book of ASTM standards-Volume 4.08, Soil and Rock, Building Stones: Philadelphia, Pa., American Society for Testing Materials, p. 345, 371.

Ball, J.W., Nordstrom, K.D., and Zachmann, D.W., 1987, WATEQ4F-A personal computer Fortran translation of the geochemical code WATEQ2 with revised data base: U.S. Geological Survey Open-File Report 87-50, $108 \mathrm{p}$.

Bates, R.L., and Jackson, J.A., 1980, Glossary of geology ( $2 \mathrm{~d}$ ed.): Falls Church, VA., American Geological Institute, $788 \mathrm{p}$.

Bolon, H.C., 1953, Low-water study of the Gasconade River Basin: U.S. Geological Survey Open-File Report 53-24, $10 \mathrm{p}$.

Budavari, Susan, O'Neil, M.J., Smith, Ann, and Heckelman, P.E., eds., 1989, The Merck index: Rahway, N.J., Merck and Co., Inc., 1,606 p.

Code of Federal Regulations, 1994, Title 40, part 136 Appendix A, Method 635, p. 574-601.

Connor, J.J., and Shacklette, H.T., 1975, Background geochemistry of some rocks, soils, plants, and vegetables in the conterminous United States: U.S. Geological Society Professional Paper 574-F, $168 \mathrm{p}$. 
Edwards, T.K., and Glysson, G.D., 1988, Field methods for measurement of fluvial sediment: U.S. Geological Survey Open-File Report 86-531, 118 p.

Eichelberger, J.W., Munch, J.W., and Beller, T.A., 1992, Measurement of purgeable organic compounds in water by capillary column gas chromatography/mass spectrometry: U.S. Environmental Protection Agency Environmental Systems Monitoring Laboratory, rev. 4.0, p. 5-51.

Fenneman, N.M., 1938, Physiography of the Eastern United States: New York, McGraw-Hill Book Co., p. 419518.

Fuller, D.L., Knight, R.D., and Harvey, E.J., 1967, Ground water, in Mineral and Water Resources of Missouri: Rolla, Missouri Division of Geology and Land Survey, v. 43, 2d ser., 399 p.

Goolsby, D.A., Coupe, R.C., and Markovchick, D.J., 1991, Distribution of selected herbicides and nitrate in the Mississippi River and its major tributaries: U.S. Geological Survey Water-Resources Investigations Report $91-4163,36 \mathrm{p}$.

Guy, H.P., and Norman, V.W., 1970, Field methods for measurement of fluvial sediments: U.S. Geological Survey Techniques of Water-Resources Investigations, book 3 , chap. C-2, 59 p.

Harrison, R.W., Orndorff, R.C., and Weems, Robert, 1996, Geology of the Fort Leonard Wood Military Reservation and adjacent areas of south-eastern Missouri, with contributions on Quaternary terraces by Paul E. Anderson, Dennis Mienert, and Grant Butler: U.S. Geological Survey Open-File Report 96-60, 255 p., 10 plates.

Harvey, E.J., 1980, Ground water in the Springfield-Salem Plateaus of southem Missouri and northern Arkansas: U.S. Geological Survey Water-Resources Investigations Report 80-101, 66 p.

Hem, J.D., 1992, Study and interpretation of the chemical characteristics of natural water (3d ed.): U.S Geological Survey Water-Supply Paper 2254, 263 p.

Horowitz, A.J., 1985, A primer on trace metal-sediment chemistry: U.S. Geological Survey Water-Supply Paper 2277, $67 \mathrm{p}$.

Imes, J.L., and Emmett, L.F., 1994, Geohydrology of the Ozark Plateaus aquifer system in parts of Missouri, Arkansas, Oklahoma, and Kansas: U.S. Geological Survey Professional Paper 1414-D, 127 p.

Imes, J.L., and Davis, J.V., 1991, Water type and concentration of dissolved solids, chloride, and sulfate in ground water from the Ozark aquifer in Missouri, Arkansas, Kansas, and Oklahoma: U.S. Geological Survey Hydrologic Investigations Atlas HA-711-K, 4 sheets.

Koenig, John W., ed., 1961, The stratigraphic succession in Missouri: Rolla, Missouri Division of Geology and Land Survey, v. 40, 2d series, 185 p.
Lidiak, E.G., Marvin, R.F., Thomas, H.H., Bass, M.N., 1966, Eastern area, part 4, in Geochronology of the Midcontinent Region, United States: Journal of Geophysical Research, v. 71, p. 5,427-5,438.

Meister Publishing Company, 1994, Farm chemicals handbook: Willoughby, Ohio, Section C, p. C1-C410.

Melton, R.W., 1976, The regional geohydrology of the Roubidoux and Gasconade Formations, Arkansas and Missouri: Fayetteville, University of Arkansas, unpublished M.S. thesis, $160 \mathrm{p}$.

McCracken, M.H., 1971, Structural features of Missouri: Rolla, Missouri Division of Geology and Land Survey Report of Investigations 49, $99 \mathrm{p}$.

Middendorf, M.A., 1984a, Geology of the Devils Elbow quadrangle, Missouri: Rolla, Missouri Division of Geology and Land Survey Open-File Map OFM-84192d-GI, 1:24,000 scale, 1 sheet. $-1984 \mathrm{~b}$, Geology of the Waynesville quadrangle, Missouri: Rolla, Missouri Division of Geology and Land Survey Open-File Map OFM-84-192c-GI, 1:24,000 scale, 1 sheet.

1986, Geology of the Dryknob, Brownfield, Drew, and Winnipeg quadrangles, Missouri: Rolla, Missouri Division of Geology and Land Survey Open-File Map OFM-84-190-GI, 1:52,500 scale, 1 sheet.

Montgomery, J.H., 1991, Ground water chemicals field guide: Chelsea, Mich., Lewis Publishing Inc., 271 p.

Muehlberger, W.R., Denison, R.E., and Lidiak, E.G., 1967, Basement rocks in continental interior of the United States: Bulletin of the American Association of Petroleum Geologists, v. 51, p. 2,351-2,380.

Muehlberger, W.R., Hedge, C.E., Denison, R.E., and Marvin, R.F., 1966, Southern area, part 3, in Geochronology of the Midcontinent Region, United States: Journal of Geophysical Research, v. 71, p. 5,409-5,426.

Mull, D.S., Liebermann, T.D., Smoot, J.L., Woosley, L.H., and Mikulak, R.J., 1988, Application of dye-tracing techniques for determining solute-transport characteristics of ground water in karst terranes: U.S. Environmental Protection Agency EPA 904/6-88-001, 103 p.

National Institute for Occupational Safety and Health, 1985, NIOSH/OSHA Pocket guide to chemical hazards: U.S. Department of Health and Human Services, DHHS No. 85-114, 249 p.

National Oceanic and Atmospheric Administration, 195180, Climatological data-National Summary: Asheville, N.C., National Climatic Data Center.

1994, Climatological data monthly summary, Missouri: Asheville, N.C., National Climatic Data Center, v. 98 , no. 11 and 12 .

Occupational Safety and Health Administration, 1989, Hazardous waste operations and emergency response: CFR 1910.120 , p. 330-330.34. 
Oesch, R.D., and Oesch, D.W., 1986, Cave resources of Ft. Leonard Wood-An inventory and evaluation: Missouri Department of Conservation, $157 \mathrm{p}$.

Office of the Federal Register, 1962 (July 16), Part 300, National oil and hazardous substances pollution contingency plan, Subpart H: Washington, D.C., Federal Register, National Archives and Records Service.

Parkhurst, D.L., Thorstenson, D.C., and Plummer, L.N., 1980, PHREEQE-A computer program for geochemical calculations: U.S. Geological Survey WaterResources Investigations 80-96, 193 p.

Radian Corporation, 1993, Final report, multi-site RCRA Investigation, Fort Leonard Wood, Missouri: Kansas City, Mo., U.S. Army Corps of Engineers.

Rantz, S.E., and others, 1982, Measurements and computation of streamflow-Volume 1. Measurement of stage and discharge: U.S. Geological Survey Water-Supply Paper 2175, $284 \mathrm{p}$.

Sawyer, C.N., and McCarty, P.L., 1978, Chemistry for environmental engineering (3rd ed.): New York, McGrawHill Inc., p. 120, 514-519.

Sax, N.I., 1984, Dangerous properties of industrial materials (6th ed.): New York, Van Nostrand Reinhold, Co.

Schumacher, J.G., Merten, L.M., Hockanson, E.A., and DeRusseau, S.N., 1996, Hydrologic and water-quality data for the Weldon Spring ordnance works, St. Charles County, Missouri, 1992-95: U.S. Geological Survey Open-File Report 96-218, 101 p.

Shelton, L.R., 1994, Field guide for the collection and processing of stream-water samples for the National Water-Quality Assessment Program: U.S. Geological Survey Open-File Report 94-455, 42 p.

Skelton, John, 1976, Missouri stream and springflow characteristics, low-flow frequency and flow duration: Rolla, Missouri Division of Geology and Land Survey Water Resources Report 32, 71 p.

Smith, J.A., Witkowski, P.J., and Fusillo, T.V., 1987, Manmade organic compounds in the surface waters of the United States-A review of current understanding: U.S. Geological Survey Open-File Report 87-209, $182 \mathrm{p}$.

Sumner, H.S., and Easson, Greg, 1986, Geology of the Bloodland, Big Piney, Roby, and Slabtown Springs quadrangles, Missouri: Rolla, Missouri Division of Geology and Land Survey Open-File Map OFM-84 189-GI, 1:24,000 scale, 1 sheet.

U.S. Army Environmental Hygiene Agency, 1988a, Interim final report, Hazardous waste consultation No. 37-261646-88, evaluation of solid waste management units, Fort Leonard Wood, Missouri, 1-4 June 1987 and 27 June-1 July 1988: Aberdeen Proving Ground, Md. -1988b, Geohydrologic study no. 38-26-0919-88, investigation of closed landfills, Fort Leonard Wood, Missouri, 29 October-6 November and 14-18 March 1988: Aberdeen Proving Ground, Md.
U.S. Army Environmental Hygiene Agency, 1990, Geohydrologic study no. 38-26-k865-91, Sampling Visit, Fort Leonard Wood, Missouri, 13-24 August-15-18 September 1990: Aberdeen Proving Ground, Md.

1992, RCRA facility assessment report: Fort Leonard Wood, Fort Leonard Wood, Missouri.

1993, Ground-water quality consultation no. 38-26KV44-93, RCRA facility assessment-Sampling Visit, Fort Leonard Wood, Missouri, 29 March-2 April 1993: Aberdeen Proving Ground, Md.

U.S. Army Toxic and Hazardous Materials Agency, 1983, Explosives in soil by HPLC, Method No. 8H: Aberdeen Proving Ground, Md.

U.S. Department of Agriculture, Soil Conservation Service, 1979, Missouri general soil map and soil association descriptions: $74 \mathrm{p}$.

1989, Soil survey of Pulaski County, Missouri: 120 p., 12 sheets.

U.S. Department of Defense, 1981, Defense environmental quality program policy memorandum (DEQPPM815).

U.S. Environmental Protection Agency, 1983, Methods for chemical analysis of water and wastes: USEPA/600/4 79-020.

_-1985, Remedial action at waste disposal sites: Washington, D.C., Office of Emergency and Remedial Response, USEPA/625/6-85/006.

1986a, Superfund exposure assessment manual:

Washington, D.C., Office of Emergency and Remedial Response.

1986b, Quality criteria for water: Office of Water Regulations and Standards, USEPA/440/5-86-001. 1986c, Methods for organic chemical analysis of municipal and industrial wastewater: Federal Register, 40 CFR 136, App. A, July 1, 1986.

1986d, Test methods for evaluating solid waste: Office of Solid Waste and Emergency Response, Washington, D.C., SW 846, v. 1A, 3rd ed.

1990, Method 8330 (Nitroaromatics and nitroamines by high performance liquid chromatography), in Test methods for evaluating solid waste, physical/chemical methods, SW 846: Washington, D.C., Office of Solid Waste and Emergency Response, rev. 0.

Vineyard, J.D., and Feder, G.L., 1974, Springs of Missouri: Rolla, Missouri Division of Geology and Land Survey, Water Resources Report 29, 266 p.

Ward, J.R., and Hair, C.A., 1990, Methods for the collection and processing of surface-water and bed-material samples for physical and chemical analyses: U.S. Geological Survey Open-File Report 90-140, 71 p.

Wood, W.W., 1976, Guidelines for the collection and field analysis of ground-water samples for selected unstable constituents: U.S. Geological Survey Techniques of Water-Resources Investigations, book 1, chap. D-1, $25 \mathrm{p}$. 
Zaugg, S.D., Sandstrom, M.W., Smith, S.G., and Fehlberg, K.M., 1995, Methods of analysis by the U.S. Geological Survey national water quality laboratory-Determination of pesticides in water by $\mathrm{C}-18$ solid-phase extraction and capillary-column gas chromatography/mass spectrometry with selection-ion monitoring: U.S. Geological Survey Open-File Report 95-181, $49 \mathrm{p}$. 
TABLES

DDGE Z1 E, OGOL- 
Table 2. Summary for injection site and attempted recovery sites during dye-trace test T103-01

\begin{tabular}{llll}
\hline Tracer Injection date: & $02-14-95$ & $\begin{array}{l}\text { Tracer Test No: } \\
\text { Project No: }\end{array}$ & $\begin{array}{l}\text { T103-01 } \\
\text { MO-10300 }\end{array}$ \\
& & Pro
\end{tabular}

Injection Site

$\begin{array}{llll}\text { Site name: } & \text { Forney Army Airport } & \text { Latitude: } & 374433 \\ \text { County: } & \text { Pulaski } & \text { Longitude: } & 0920802 \\ \text { Quadrangle: } & \text { Bloodland } & \text { Land net: } & \text { sec. 22, T. 35 N, R. 11 W } \\ \text { Altitude: } & 1,075 \pm 10 \text { feet } & \text { Quarter section: } & \text { SE1/4 NW1/4 SW1/4; CBD }\end{array}$

Site description: $\quad$ Large sinkhole, about 100 feet in diameter, domed interior; probable cave collapse.

Field conditions: $\quad$ Overcast sky; intermittent sleet, temperature about 30 degrees Fahrenheit.

Hydrologic conditions: _ low flow; _ _ high flow; _ $\mathbf{x}_{-}$high-base flow; __ low-base flow; _ flood flow

$\begin{array}{llll}\text { Tracing agent: } & \text { Rhodamine WT } & \text { Pre-injection flush: } 100 \text { gallons } \\ \text { Agent quantity: } & 3 \text { liters } & \text { Post-injection flush: } 400 \text { gallons } \\ \text { Time: } & 1: 05 \text { p.m. } & \text { Investigator(s): } & \text { Imes/Brenden/Hockanson }\end{array}$

Remarks: Water for pre- and post-injection flushes was provided by the Fort Leonard Wood fire department. Rory McCarthy (Fort Leonard Wood, Directorate of Public Works, Environmental Officer) and Diana Travis (Missouri Division of Geology and Land Survey) observed the dye injection. Onsite survey of the area south of the injection site yielded six sinkholes of varying sizes. One sinkhole contained a distinct conduit to the subsurface. Dye was detected at Shanghai Spring 10 to 13 days after injection.

Attempted Recovery Sites

\begin{tabular}{|c|c|c|c|c|c|}
\hline No. & Site name & $\begin{array}{l}\text { Latitude-longitude } \\
\text { (degrees mlnutes seconds) }\end{array}$ & $\begin{array}{l}\text { Sample } \\
\text { method }\end{array}$ & $\begin{array}{l}\text { Distance } \\
\text { (mlles) }\end{array}$ & $\begin{array}{l}\text { Test } \\
\text { results }^{a}\end{array}$ \\
\hline 1 & Miller Spring & $374204-0920414$ & Charcoal & 4.49 & $\mathrm{n}$ \\
\hline 2 & Pumping station spring & $374416-0920451$ & Charcoal & 2.92 & $\mathrm{n}$ \\
\hline 3 & Shanghai Spring & $374951-0920515$ & Charcoal & 6.55 & $\mathbf{p}$ \\
\hline 4 & Ballard Hollow Stream near Laughlin Cemetery & $374636-0920948$ & Charcoal & 2.85 & $\mathrm{n}$ \\
\hline 5 & Small spring in Tunnel Hollow & $374745-0920926$ & Charcoal & 3.89 & $\mathbf{n}$ \\
\hline 6 & Roubidoux Spring & $374931-0921205$ & Charcoal & 6.80 & $\mathbf{n}$ \\
\hline 7 & Creasy Spring & $375037-0921538$ & Charcoal & 9.83 & $\mathrm{n}$ \\
\hline 8 & Stone Mill Spring & $374424-0920229$ & Charcoal & 5.07 & $\mathrm{n}$ \\
\hline 9 & Bartlett Mill Spring & $375043-0921503$ & Charcoal & 9.55 & $\mathrm{n}$ \\
\hline
\end{tabular}

\footnotetext{
${ }^{a} \mathrm{p}$, positive dye detection; $\mathrm{n}$, no dye detected.
} 
Table 3. Summary for successful dye recovery at Shanghai Spring during dye-trace test T103-01

\begin{tabular}{llll}
\hline Tracer injection date: & $02-14-95$ & Tracer Test No: & T103-01 \\
& & Project No: & M0-10300
\end{tabular}

\section{Injection Site}

$\begin{array}{llll}\text { Site name: } & \text { Forney Army Airport } & \text { Latitude: } & 374433 \\ \text { County: } & \text { Pulaski } & \text { Longitude: } & 0920802 \\ \text { Quadrangle: } & \text { Bloodland } & \text { Land net: } & \text { sec. 22, T. 35 N, R. 11 W } \\ \text { Altitude: } & 1,075 \pm 10 \text { feet } & \text { Quarter section: } & \text { SE1/4 NW1/4 SW1/4; CBD }\end{array}$

Site description:

Field conditions:

Hydrologic conditions:

Tracing agent:

Agent quantity:

Time:

Large sinkhole, about 100 feet in diameter, domed interior; probable cave collapse. Overcast sky; intermittent sleet, temperature about 30 degrees Fahrenheit. low flow; __ high flow; _ $\mathrm{x}_{-}$high-base flow; low-base flow; flood flow

Rhodamine WT

3 liters

1:05 p.m.

\author{
Pre-injection flush: \\ Post-injection flush: \\ Investigator(s):
}

100 gallons

400 gallons

Imes/Brenden/Hockanson

\section{Recovery Site}

$\begin{array}{ll}\text { Site name: } & \text { Shanghai Spring } \\ \text { County: } & \text { Pulaski } \\ \text { Quadrangle: } & \text { Devils Elbow } \\ \text { Altitude: } & 715 \text { feet }\end{array}$

Sampling method: Analytical method:

\author{
Activated coconut charcoal \\ Scanning spectrofluorophotometer
}

\author{
Latitude: \\ Longitude: \\ Land net: \\ Quarter section:
}

Trace length:

Travel time:
374951

0920515

sec. 24, T. 36 N, R. $11 \mathrm{~W}$

NE1/4 NE1/4 SW1/4; CAA

File names of the sequence of traces indicating a positive dye recovery

$\begin{array}{lll}19950213.06 & 19950216.09 & 19950221.09 \\ 19950224.09 & 19950227.09 & 19950303.09\end{array}$

Remarks: The relatively short period (10 to 13 days) that dye passed through Shanghai Spring indicates that water primarily is transported from the injection site to the spring through a single well-defined fracture or bedding-plane opening. Dye concentrations before and after this 3 -day period were small relative to the maximum dye concentration. Flow rate along path carrying greatest dye load is about 0.5 mile per day. 
Table 4. Summary for injection site and attempted recovery sites during dye-trace test T103-02

\begin{tabular}{llll}
\hline Tracer injection date: & 03-16-95 & $\begin{array}{l}\text { Tracer Test No: } \\
\text { Project No: }\end{array}$ & $\begin{array}{l}\text { T103-02 } \\
\text { MO-10300 }\end{array}$ \\
\hline & & Injection Site & \\
& & & 374318 \\
Site name: & SWMU FLW-003 & Latitude: & 0920816 \\
County: & Pulaski & Longitude: & sec. 33, T. 35 N, R. 11 W \\
Quadrangle: & Bloodland & Land net: & SE1/4 NE1/4 NE1/4; AAC \\
Altitude: & $1,098 \pm 5$ feet & Quarter section: &
\end{tabular}

Site description:

Field conditions:

Hydrologic conditions:

Tracing agent:

Agent quantity:

Time:
About 200 feet into wooded area at south edge of solid-waste management unit FLW-003. Partly cloudy; about 75 degrees Fahrenheit; previous rainfall about 1 week before injection. low flow high flow; _. $\mathbf{x}_{-}$high-base flow; low-base flow; flood flow

Rhodamine WT
4 liters
2:40 p.m.

Pre-injection flush: Post-injection flush: Investigator(s):

60 gallons 600 gallons Imes/Brenden

Remarks: Injection in small sinkhole at south edge of solid-waste management unit FLW-003. Sinkhole is about 6 feet in diameter and 5 feet deep and located between two old manmade trenches. Preliminary to the injection, an 8- to 10-inch thick mass of rootlets and organic material was dug from the hole, exposing rock rubble. Rocks were removed to a depth of about 1.5 feet during the preinjection flush. The sinkhole contained no clay fill and accepted flush water at a rate of about 2.5 gallons per minute. Two other small sinkholes in the area contained substantial clay fill and were unsuitable as injection sites. The post-injection flush was conducted in two stages; a 200 -gallon flush at the time of dye injection and a 400-gallon flush 4 days after injection. The dye apparently remained trapped in clay deposits beneath the "sinkhole."

Attempted Recovery Sites

\begin{tabular}{|c|c|c|c|c|c|}
\hline No. & Site name & $\begin{array}{l}\text { Latitude-longitude } \\
\text { (degrees minutes seconds) }\end{array}$ & $\begin{array}{l}\text { Sample } \\
\text { method }\end{array}$ & $\begin{array}{l}\text { Distance } \\
\text { (miles) }\end{array}$ & $\begin{array}{l}\text { Test } \\
\text { results }^{a}\end{array}$ \\
\hline 1 & Miller Spring & $374204-0920414$ & Charcoal & 3.93 & $\mathrm{n}$ \\
\hline 2 & Pumping station spring & $374416-0920451$ & Charcoal & 3.30 & $\mathrm{n}$ \\
\hline 3 & Shanghai Spring & $374951-0920515$ & Charcoal & 8.02 & $\mathrm{n}$ \\
\hline 4 & Ballard Hollow Stream near Laughlin Cemetery & $374636-0920948$ & Charcoal & 4.03 & $\mathrm{n}$ \\
\hline 5 & Small spring in Tunnel Hollow & $374745-0920926$ & Charcoal & 5.23 & $\mathrm{n}$ \\
\hline 6 & Roubidoux Spring & $374931-0921205$ & Charcoal & 7.94 & $\mathrm{n}$ \\
\hline 7 & Stone Mill Spring & $374424-0920229$ & Charcoal & 5.44 & $\mathrm{n}$ \\
\hline 8 & Unnamed stream 0.3 mile south of pumping station & $374347-0920517$ & Charcoal & 2.78 & $\mathrm{n}$ \\
\hline 9 & "Asphalt Plant" stream & $374303-0920456$ & Charcoal & 3.11 & $\mathrm{n}$ \\
\hline 10 & Ousley Spring & $374747-0920156$ & Charcoal & 7.73 & $\mathrm{n}$ \\
\hline
\end{tabular}

\footnotetext{
$a_{\text {n, no dye detected. }}$
} 
Table 5. Summary for injection site and attempted recovery sites during dye-trace test T103-03

\begin{tabular}{llll}
\hline Tracer injectlon date: & 04-17-95 & $\begin{array}{l}\text { Tracer Test No: } \\
\text { Project No: }\end{array}$ & $\begin{array}{l}\text { T103-03 } \\
\text { M0-10300 }\end{array}$ \\
\hline \multicolumn{5}{l}{ Injection Site } \\
& & & \\
Site name: & Bradford Cemetery Sinkhole & Latitude: & 374210 \\
County: & Pulaski & Longitude: & 0920702 \\
Quadrangle: & Big Piney & Land net: & sec. 2, T. 34 N, R. 11 W \\
Altitude: & $1,040 \pm 5$ feet & Quarter section: & SE1/4 NW1/4 NW1/4; BBD
\end{tabular}

Site description:

Field conditions:

Hydrologic conditions:

Tracing agent:

Agent quantity:

Time:
About 300 feet from Bradford Cemetery Road in large ( 300 by 150 feet) sinkhole.

Cloudy; about 70 degrees Fahrenheit; intermittent light rainfall, storm approaching. _low flow; _ $\mathbf{x}$ _ high flow; __ high-base flow; low-base flow; flood flow
Pre-injection flush:

Post-injection flush: Investigator(s):
100 gallons

500 gallons

Imes/Kleeschulte

Remarks: Injection in hole in northeast side of base of large sinkhole located about 300 feet southwest of bend in Bradford Cemetery Road. Sinkhole is elliptical, about 300 by 150 feet, and about 60 feet deep. The injection was in a pit having a surface opening about 12 by 18 inches and expanding into a cavity about 6 feet long by 4 feet wide by 5 feet deep. The injected dye and water entered the ground through a small hole beneath a large boulder in the bottom of the cavity.

Attempted Recovery Sites

\begin{tabular}{|c|c|c|c|c|c|}
\hline No. & Site name & $\begin{array}{l}\text { Latitude-iongitude } \\
\text { (degrees minutes seconds) }\end{array}$ & $\begin{array}{l}\text { Sampie } \\
\text { method }\end{array}$ & $\begin{array}{l}\text { Distance } \\
\text { (miles) }\end{array}$ & $\begin{array}{l}\text { Test } \\
\text { resuits }^{a}\end{array}$ \\
\hline 1 & Miller Spring & $374204-0920414$ & Charcoal & 3.93 & $\mathbf{p}$ \\
\hline 2 & Pumping station spring & $374416-0920451$ & Charcoal & 3.30 & $\mathbf{n}$ \\
\hline 3 & Shanghai Spring & $374951-0920515$ & Charcoal & 8.02 & n \\
\hline 4 & Ballard Hollow Stream near Laughlin Cemetery & $374636-0920948$ & Charcoal & 4.03 & $\mathbf{n}$ \\
\hline 5 & Small spring in Tunnel Hollow & $374745-0920926$ & Charcoal & 5.23 & $\mathbf{n}$ \\
\hline 6 & Roubidoux Spring & $374931-0921205$ & Charcoal & 7.94 & $\mathbf{n}$ \\
\hline 7 & Stone Mill Spring & $374424-0920229$ & Charcoal & 5.44 & $\mathbf{n}$ \\
\hline 8 & Unnamed stream 0.3 mile south of pumping station & $374347-0920517$ & Charcoal & 2.78 & $\mathbf{n}$ \\
\hline 9 & "Asphalt Plant" stream & $374303-0920456$ & Charcoal & 3.11 & $\mathrm{n}$ \\
\hline 10 & Ousley Spring & $374747-0920156$ & Charcoal & 7.73 & $\mathbf{n}$ \\
\hline
\end{tabular}

\footnotetext{
ap, positive dye detection; $n$, no dye detected.
} 
Table 6. Summary for successful dye recovery at Miller Spring during dye-trace test T103-03

Tracer Test No: T103-03

Project No: MO-10300

\section{Injection Site}

Site name:

County:

Quadrangle:

Altitude:

Site description:

Field conditions:

Hydrologic conditions:

Tracing agent:

Agent quantity:

Time:
Bradford Cemetery Sinkhole

Pulaski

Big Piney

$1,040 \pm 5$ feet
Latitude:

Longitude:

Land net:

Quarter section:
374210

0920702

sec. 2, T. $34 \mathrm{~N}$, R. $11 \mathrm{~W}$

SE1/4 NW1/4 NW1/4; BBC

About 300 feet from Bradford Cemetery Road in large ( 300 by 150 feet) sinkhole.

Cloudy; about 70 degrees Fahrenheit; intermittent light rainfall, storm approaching. low flow; _. high-base flow; low-base flow; flood flow

Fluorescein
$2 \mathrm{lbs}$
1:30 p.m.

Pre-injection flush: Post-injection flush: Investigator(s):
100 gallons

500 gallons

Imes/Kleeschulte

\section{Recovery Site}

Site name:

County:

Quadrangle:

Altitude:

Sampling method:

Analytical method:
Miller Spring

Pulaski

Big Piney

798 feet

Activated coconut charcoal
Scanning spectrofluorophotometer
Latitude:

Longitude:

Land net:

Quarter section:
374204

0920414

sec. 6, T. $34 \mathrm{~N}$, R. $10 \mathrm{~W}$

SE1/4 NW1/4 NE1/4; ABD

File names of the sequence of traces indicating a positive dye recovery

$\begin{array}{lll}19950414.04 & 19950417.04 & 19950421.04 \\ 19950424.04 & 19950427.04 & \end{array}$

Remarks: The first dye detection at Miller Spring occurred within 4 days of injection. Concentrations of dye at the spring remained at maximum levels 4 to 7 days after injection, then began decreasing from peak values. Flow rate along path carrying greatest dye load is about 1 mile per day. 
Table 7. Summary for injection site and attempted recovery sites during dye-trace test T103-04

\begin{tabular}{llll}
\hline Tracer injection date: & $05-09-95$ & Tracer Test No: & T103-04 \\
& & Project No: & MO-10300 \\
\hline
\end{tabular}

Injection Site

$\begin{array}{llll}\text { Site name: } & \text { Range 18 sinkhole series } & \text { Latitude: } & 374026 \\ \text { County: } & \text { Pulaski } & \text { Longitude: } & 0920815 \\ \text { Quadrangle: } & \text { Bloodland } & \text { Land net: } & \text { sec. 10, T. 34 N, R. 11 W } \\ \text { Altitude: } & 1,100 \text { feet } & \text { Quarter section: } & \text { NW 1/4 SW 1/4 NW 1/4; BCB }\end{array}$

Site description:

Field conditions:

Hydrologic conditions:

Tracing agent:

Agent quantity:

Time:
0.97 mile from solid-waste management unit FLW-001 and dirt road at north edge of Range 18. Cloudy; about 60 degrees Fahrenheit. low flow; _ nigh flow; _. $x_{\text {_ }}$ high-base flow; low-base flow; flood flow
Pre-injection flush: Post-injection flush: Investigator(s):
None
500 gallons
Imes/Brenden

Remarks: Injection in eastern-most sinkhole of a series of four sinkholes approximately parallel to the dirt road along the northern edge of Range 18. The sinkhole is about 20 by 12 feet with a small pit beneath a large rock in the north side of the sinkhole. During the flushing operation, the base of the pit collapsed, revealing a 10 to 15 feet deep cavity beneath the pit and overhanging rock.

Attempted Recovery Sites

\begin{tabular}{rlcccc}
\hline No. & \multicolumn{1}{c}{ Site name } & $\begin{array}{c}\text { Latitude-longitude } \\
\text { (degrees minutes seconds) }\end{array}$ & $\begin{array}{c}\text { Sample } \\
\text { method }\end{array}$ & $\begin{array}{c}\text { Distance } \\
\text { (miles) }\end{array}$ & $\begin{array}{c}\text { Test } \\
\text { results }^{\mathrm{a}}\end{array}$ \\
\hline & & & & & \\
$\mathbf{1}$ & Miller Spring & $\mathbf{3 7 4 2 0 4 - 0 9 2 0 4 1 4}$ & Charcoal & $\mathbf{4 . 0 8}$ & $\mathbf{p}$ \\
2 & Pumping station spring & $374416-0920451$ & Charcoal & 5.38 & $\mathrm{n}$ \\
3 & Shanghai Spring & $374951-0920515$ & Charcoal & 11.12 & $\mathrm{n}$ \\
4 & Ballard Hollow spring & $374830-0921056$ & Charcoal & 6.72 & $\mathrm{n}$ \\
5 & Small spring in Tunnel Hollow & $374745-0920926$ & Charcoal & 8.49 & $\mathrm{n}$ \\
6 & Roubidoux Spring & $374931-0921205$ & Charcoal & 11.00 & $\mathrm{n}$ \\
7 & Stone Mill Spring & $374424-0920229$ & Charcoal & 6.97 & $\mathrm{n}$ \\
8 & Unnamed stream 0.3 mile south of pumping station & $374347-0920517$ & Charcoal & 4.72 & $\mathrm{n}$ \\
9 & "Asphalt Plant" stream & $374303-0920456$ & Charcoal & 4.28 & $\mathrm{n}$ \\
10 & Ousley Spring & $374747-0920156$ & Charcoal & 10.23 & $\mathrm{n}$ \\
& & & & & \\
\hline
\end{tabular}

ap, positive dye detection; $n$, no dye detected. 
Table 8. Summary for successful dye recovery at Miller Spring during dye-trace test T103-04

\begin{tabular}{llll}
\hline Tracer injection date: & $05-09-95$ & Tracer Test No: & T103-04 \\
& & ProJect No: & MO-10300
\end{tabular}

Injection Site

$\begin{array}{llll}\text { Site name: } & \text { Range 18 sinkhole series } & \text { Latitude: } & 374026 \\ \text { County: } & \text { Pulaski } & \text { Longitude: } & 0920815 \\ \text { Quadrangle: } & \text { Bloodland } & \text { Land net: } & \text { sec. 10, T. 34 N, R. 11 W } \\ \text { Altitude: } & 1,100 \text { feet } & \text { Quarter section: } & \text { NW1/4 SW1/4 NW 1/4; BCB }\end{array}$

Site description:

Field conditions:

Hydrologic conditions:

Tracing agent:

Agent quantity:

Time:

0.97 mile from solid-waste management unit FLW-001 and dirt road at north edge of Range 18. Cloudy; about 60 degrees Fahrenheit.

_ low flow; __ high flow; _ $\mathrm{x}_{-}$high-base flow; low-base flow; flood flow

$\begin{array}{lll}\text { Fluorescein } & \text { Pre-injection flush: } & \text { None } \\ 2.5 \mathrm{lbs} & \text { Post-injection flush: } & 500 \text { gallons } \\ \text { 11:30 a.m. } & \text { Investigator(s): } & \text { Imes/Brenden }\end{array}$

\section{Recovery Site}

$\begin{array}{llll}\text { Site name: } & \text { Miller Spring } & \text { Latitude: } & 374204 \\ \text { County: } & \text { Pulaski } & \text { Longitude: } & 0920414 \\ \text { Quadrangle: } & \text { Big Piney } & \text { Land net: } & \text { sec. 6, T. 34 N, R. 10 W } \\ \text { Altitude: } & 798 \text { feet } & \text { Quarter section: } & \text { SE1/4 NW1/4 NE1/4; ABD } \\ & & & \\ \text { Sampling method: } & \text { Activated coconut charcoal } & \text { Trace length: } & 4.08 \text { miles } \\ \text { Analytical method: } & \text { Scanning spectrofluorophotometer } & \text { Travel time: } & \text { about 13 days }\end{array}$

File names of the sequence of traces indicating a positive dye recovery

$\begin{array}{lll}19950505.04 & 19950508.04 & 19950512.04 \\ 19950515.04 & 19950519.04 & 19950522.04 \\ 19950526.04 & 19950530.04 & \end{array}$

Remarks: Dye concentrations from elutriated charcoal packets placed in Miller Spring were largest about 13 days after injection. The slow rate of increase and decrease of dye concentrations as dye passed through the spring suggests a complex multi-path flow system. Flow rate along path carrying greatest dye load is about 0.3 mile per day. 
Table 9. Summary for injection site and attempted recovery sites during dye-trace test T103-05

\begin{tabular}{llll}
\hline Tracer Injectlon date: & $05-26-95$ & Tracer Test No: & T103-05 \\
& & Project No: & MO-10300
\end{tabular}

\section{Injection Site}

$\begin{array}{llll}\text { Site name: } & \text { Pulaski Avenue } & \text { Latitude: } & 374647 \\ \text { County: } & \text { Pulaski } & \text { Longitude: } & 0920817 \\ \text { Quadrangle: } & \text { Waynesville } & \text { Land net: } & \text { sec. 9, T. 35.N, R. 11 W } \\ \text { Altitude: } & 1,045 \text { feet } & \text { Quarter section: } & \text { SE1/4 NE1/4 NE1/4; AAD }\end{array}$

Site description:

Field conditions:

Hydrologic conditions:

Tracing agent:

Agent quantity:

Time:
700 feet east of intersection of Pulaski and Indiana Avenues; north side of road. Overcast with showers; considerable rainfall in past week. _ low flow; _ $\mathbf{x}_{-}$high flow; __ high-base flow; ___ low-base flow; flood flow

Fluorescein
1.25 to $1.50 \mathrm{lbs}$
$2: 15$ p.m.

2:15 p.m.
Pre-injection flush: Post-injection flush: Investigator(s):
50 gallons 450 gallons Brenden

Remarks: Injection in hole beneath large elm tree at southern edge of eastern-most sinkhole of two sinkholes located along Pulaski Avenue. Road passes through western-most sinkhole, which has a flat vegetated bottom and no drainage hole. Intense rainfall occurred within 2 hours of the dye injection.

Attempted Recovery Sites

\begin{tabular}{|c|c|c|c|c|c|}
\hline No. & Slte name & $\begin{array}{l}\text { Latitude-longitude } \\
\text { (degrees minutes seconds) }\end{array}$ & $\begin{array}{l}\text { Sample } \\
\text { method }\end{array}$ & $\begin{array}{l}\text { Distance } \\
\text { (mlles) }\end{array}$ & $\begin{array}{c}\text { Test } \\
\text { results }\end{array}$ \\
\hline 1 & Miller Spring & $374204-0920414$ & Charcoal & 6.55 & $\mathrm{n}$ \\
\hline 2 & Pumping station spring & $374416-0920451$ & Charcoal & 4.26 & n \\
\hline 3 & Shanghai Spring & 374951 - 0920515 & Charcoal & 4.49 & $\mathbf{p}$ \\
\hline 4 & Ballard Hollow spring & $374830-0921056$ & Charcoal & 1.30 & $\mathrm{n}$ \\
\hline 5 & Small spring in Tunnel Hollow & $374745-0920926$ & Charcoal & 1.52 & $\mathrm{n}$ \\
\hline 6 & Roubidoux Spring & $374931-0921205$ & Charcoal & 4.69 & $\mathrm{n}$ \\
\hline 7 & Stone Mill Spring & $374424-0920229$ & Charcoal & 5.97 & n \\
\hline 8 & Unnamed stream 0.3 mile south of pumping station & $374347-0920517$ & Charcoal & 4.25 & $\mathrm{n}$ \\
\hline 9 & “Asphalt Plant" stream & $374303-0920456$ & Charcoal & 4.40 & $\mathrm{n}$ \\
\hline 10 & Ousley Spring & $374747-0920156$ & Charcoal & 5.91 & $\mathrm{n}$ \\
\hline 11 & Roubidoux Creek near Burchard Hollow & $374611-0920929$ & Charcoal & 3.15 & $\mathbf{n}$ \\
\hline
\end{tabular}

ap, positive dye detection; $n$, no dye detected. 


\begin{tabular}{llll}
\hline Tracer injection date: & 05-26-95 & $\begin{array}{l}\text { Tracer Test No: } \\
\text { Project No: }\end{array}$ & $\begin{array}{l}\text { T103-05 } \\
\text { MO-10300 }\end{array}$ \\
\hline & & Injection Site & \\
& & & \\
Site name: & Pulaski Avenue & Latitude: & 374647 \\
County: & Pulaski & Longitude: & 0920817 \\
Quadrangle: & Waynesville & Land net: & sec. $9, \mathrm{~T} .35 \mathrm{~N}, \mathrm{R} .11 \mathrm{~W}$ \\
Altitude: & 1,045 feet & Quarter section: & SE1/4 NE1/4 NE1/4; AAD
\end{tabular}

Site description:

Field conditions:

Hydrologic conditions:

Tracing agent:

Agent quantity:

Time:

700 feet east of intersection of Pulaski and Indiana Avenues; north side of road.

Overcast with showers; considerable rainfall in past week.

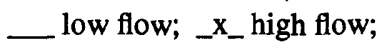
high-base flow; low-base flow; flood flow

$\begin{array}{lll}\text { Fluorescien } & \text { Pre-injection flush: } & 50 \text { gallons } \\ 1.25 \text { to } 1.50 \mathrm{lbs} & \text { Post-injection flush: } & \mathbf{4 5 0} \text { gallons } \\ \text { 2:15 p.m. } & \text { Investigator(s): } & \text { Brenden }\end{array}$

\section{Recovery Site}

$\begin{array}{ll}\text { Site name: } & \text { Shanghai Spring } \\ \text { County: } & \text { Pulaski } \\ \text { Quadrangle: } & \text { Devils Elbow } \\ \text { Altitude: } & 715 \text { feet }\end{array}$

Sampling method: Analytical method:

\author{
Activated coconut charcoal \\ Scanning spectrofluorophotometer
}

\author{
Latitude: \\ Longitude: \\ Land net: \\ Quarter section:
}

374951

0920515

sec. 24 , T. $36 \mathrm{~N}$, R. $11 \mathrm{~W}$

NE1/4 NE1/4 SW1/4; CAA

File names of the sequence of traces indicating a positive dye recovery

$\begin{array}{lll}19950526.11 & 19950530.11 & 19950602.11 \\ 19950605.11 & 19950609.11 & 19950616.11 \\ 19950623.11 & 19950630.11 & \end{array}$

Remarks: Peak dye concentrations at the spring occurred 10 to 14 days after dye injection. The slower rate of increase and decrease of dye concentrations about the peak value as compared to dye-trace test T103-01 indicates a more complex multichannel flow path from the Pulaski Avenue sinkhole to Shanghai Spring than from the Forney Army Airport sinkhole to Shanghai Spring. Flow rate along path carrying greatest dye load is about 0.4 mile per day. 
Table 11. Summary for injection site and attempted recovery sites during dye-tract test T103-06

\begin{tabular}{llll}
\hline Tracer injection date: & $\mathbf{0 7 - 0 6 - 9 5}$ & $\begin{array}{l}\text { Tracer Test No: } \\
\text { Project No: }\end{array}$ & $\begin{array}{l}\text { T103-06 } \\
\text { MO-10300 }\end{array}$ \\
& & Poct
\end{tabular}

\section{Injection Site}

$\begin{array}{llll}\text { Site name: } & \text { Hurd Hollow Stream } & \text { Latitude: } & 374205 \\ \text { County: } & \text { Pulaski } & \text { Longitude: } & 0921319 \\ \text { Quadrangle: } & \text { Bloodland } & \text { Land net: } & \text { sec. 2, T. 34 N, R. 12 W } \\ \text { Altitude: } & 902 \pm 5 \text { feet } & \text { Quarter section: } & \text { NE1/4 SE1/4 NW1/4; BDA }\end{array}$

Site description: In streambed of Hurd Hollow near point of flow loss in pool of water with small inflow.

Field conditions: $\quad$ Partly sunny — scattered rainfall during the week.

Hydrologic conditions: __ _ _ low flow; _ _ high flow; _ _ high-base flow; __ low-base flow; _ flood flow

$\begin{array}{llll}\text { Tracing agent: } & \text { Rhodamine WT } & \text { Pre-injection flush: } & \text { None } \\ \text { Agent quantity: } & 1 \text { gallon } & \text { Post-injection flush: } & \text { None } \\ \text { Time: } & 3: 30 \text { p.m. } & \text { Investigator(s): } & \text { Brenden/Collier }\end{array}$

Remarks: Injection in pool of water near the point where Hurd Hollow Stream loses flow. Some rainfall occurred the night before the injection.

Attempted Recovery Sites

\begin{tabular}{|c|c|c|c|c|c|}
\hline No. & Site name & $\begin{array}{l}\text { Latitude-longitude } \\
\text { (degrees minutes seconds) }\end{array}$ & $\begin{array}{l}\text { Sample } \\
\text { method }\end{array}$ & $\begin{array}{l}\text { Distance } \\
\text { (mlles) }\end{array}$ & $\begin{array}{l}\text { Test } \\
\text { results }\end{array}$ \\
\hline 1 & Creasy Spring & $375037-0921538$ & Charcoal & 10.02 & $\mathrm{n}$ \\
\hline 2 & Roubidoux Spring & $374931-0921205$ & Charcoal & 8.63 & $\mathbf{p}$ \\
\hline 3 & Roubidoux Creek near Burchard Hollow & $374611-0920929$ & Charcoal & 7.70 & $\mathrm{n}$ \\
\hline 4 & Tunnel Hollow spring & $374745-0920926$ & Charcoal & 7.42 & $\mathrm{n}$ \\
\hline 5 & Ballard Hollow spring & $374830-0921056$ & Charcoal & 5.87 & $\mathrm{n}$ \\
\hline 6 & Miller Spring & $374204-0920414$ & Charcoal & 8.29 & $\mathrm{n}$ \\
\hline 7 & Road FLW 32 tributary & $374347-0920517$ & Charcoal & 7.63 & $\mathrm{n}$ \\
\hline 8 & Pumping station spring & $374416-0920451$ & Charcoal & 8.16 & $\mathrm{n}$ \\
\hline 9 & Stone Mill Spring & $374424-0920229$ & Charcoal & 10.27 & $\mathrm{n}$ \\
\hline 10 & Shanghai Spring & $374951-0920515$ & Charcoal & 11.57 & $\mathrm{n}$ \\
\hline
\end{tabular}

${ }^{a}$ p, positive dye detection; $n$, no dye detected. 


\begin{tabular}{llll}
\hline Tracer injection date: & 07-06-95 & $\begin{array}{l}\text { Tracer Test No: } \\
\text { Project No: }\end{array}$ & $\begin{array}{l}\text { T103-06 } \\
\text { MO-10300 }\end{array}$ \\
\hline & & Injection Site & \\
Site name: & Hurd Hollow Stream & Latitude: & 374205 \\
County: & Pulaski & Longitude: & 0921319 \\
Quadrangle: & Bloodland & Land net: & sec. 2, T. 34 N, R. 12 W \\
Altitude: & $902 \pm 5$ feet & Quarter section: & NE1/4 SE1/4 NW1/4; BDA
\end{tabular}

Site description:

Field conditions:

Hydrologic conditions:

Tracing agent:

Agent quantity:

Time:

In streambed of Hurd Hollow near point of flow loss in pool of water with small inflow. Partly sunny-scattered rainfall during the week. _. low-base flow; flood flow

\author{
Rhodamine WT \\ 1 gallon \\ 3:30 p.m.
}

\begin{abstract}
Pre-injection flush: None
Post-injection flush: None

Investigator(s): Brenden/Collier
\end{abstract}

\section{Recovery Site}

$\begin{array}{llll}\text { Site name: } & \text { Roubidoux Spring } & \text { Latitude: } & 374931 \\ \text { County: } & \text { Pulaski } & \text { Longitude: } & 0921205 \\ \text { Quadrangle: } & \text { Waynesville } & \text { Land net: } & \text { sec. 25, T. 36 N, R. 12 W } \\ \text { Altitude: } & 770 \text { feet } & \text { Quarter section: } & \text { SE1/4 NE1/4 NW1/4; BAD } \\ & & & \\ \text { Sampling method: } & \text { Activated coconut charcoal } & \text { Trace length: } & 8.63 \text { miles } \\ \text { Analytical method: } & \text { Scanning spectrofluorophotometer } & \text { Travel time: } & 8 \text { to } 15 \text { days }\end{array}$

File names of the sequence of traces indicating a positive dye recovery

$\begin{array}{lll}19950630.10 & 19950706.02 & 19950714.02 \\ 19950721.02 & 19950728.02 & 19950804.02\end{array}$

Remarks: Dye recovery at Roubidoux Spring was confined to a relatively small time range compared to the total period during which recovery was attempted. Dye concentrations before and after the 8- to 15-day travel time were small as compared with peak concentrations. Flow rate along path carrying greatest dye load is about 0.5 to 1 mile per day.

Dye was not recovered in a charcoal packet placed in Roubidoux Creek between the point at which flow returns to Roubidoux Creek near Ballard Hollow and Roubidoux Spring. This indicates that the source of water in Roubidoux Creek downstream from the long dry reach is discharge of shallow ground water from nearby upland areas. Surface water lost to karst terrane beneath Roubidoux Creek near the Cannon Range apparently flows beneath the lower reach of Roubidoux Creek and discharges at Roubidoux Spring. 
Table 13. Summary for injection site and attempted recovery sites during dye-trace test T103-07

\begin{tabular}{llll}
\hline Tracer Injection date: & $\mathbf{0 7 - 1 3 - 9 5}$ & $\begin{array}{l}\text { Tracer Test No: } \\
\text { Project No: }\end{array}$ & $\begin{array}{l}\text { T103-07 } \\
\text { MO-10300 }\end{array}$ \\
\hline
\end{tabular}

\section{Injection Site}

$\begin{array}{llll}\text { Site name: } & \text { Sinkhole at junction of FLW 24 and FLW 22 } & \text { Latitude: } & 374442 \\ \text { County: } & \text { Pulaski } & \text { Longitude: } & 0920544 \\ \text { Quadrangle: } & \text { Big Piney } & \text { Land net: } & \text { sec. 24, T. 35 N, R. 11 W } \\ \text { Altitude: } & 1,010 \text { feet } & \text { Quarter section: } & \text { SE1/4 SW 1/4 NW1/4; BCD }\end{array}$

Site description:

Field conditions:

Hydrologic conditions:

Tracing agent:

Agent quantity:

Time:
Large sinkhole at south side of junction of roads FLW 24 (pumping station) and FLW 22. Hot, humid, and sunny. No rainfall in the past week. _. low flow; __ high flow; __ high-base flow; low-base flow; flood flow

$$
\begin{aligned}
& \text { Fluorescein } \\
& 0.50 \mathrm{lb} \\
& \text { 10:20 p.m. }
\end{aligned}
$$
Pre-injection flush:
Post-injection flush:
Investigator(s):

Remarks: Sinkhole had two visible openings in the southeast corner. A large amount of organic matter was removed from around both openings in the event one would not take flush water. Largest opening was used and was opened to 1.5 feet diameter by 1.5 feet deep before flushing. Opening took flush water quickly with minimum amount of pooling. Water never overflowed the opening at

\begin{tabular}{|c|c|c|c|c|c|}
\hline No. & Slte name & $\begin{array}{l}\text { Latitude-longitude } \\
\text { (degrees minutes seconds) }\end{array}$ & $\begin{array}{l}\text { Sample } \\
\text { method }\end{array}$ & $\begin{array}{l}\text { Distance } \\
\text { (mlles) }\end{array}$ & $\begin{array}{l}\text { Test } \\
\text { results }^{a}\end{array}$ \\
\hline 1 & Creasy Spring & $375037-0921538$ & Charcoal & 11.32 & $\mathrm{n}$ \\
\hline 2 & Roubidoux Spring & $374931-0921205$ & Charcoal & 7.99 & $\mathrm{n}$ \\
\hline 3 & Roubidoux Creek near Burchard Hollow & $374611-0920929$ & Charcoal & 6.46 & $\mathbf{n}$ \\
\hline 4 & Tunnel Hollow spring & $374745-0920926$ & Charcoal & 4.86 & $\mathrm{n}$ \\
\hline 5 & Ballard Hollow spring & $374830-0921056$ & Charcoal & 3.78 & $\mathbf{n}$ \\
\hline 6 & Miller Spring & $374204-0920414$ & Charcoal & 3.33 & $\mathrm{n}$ \\
\hline 7 & Road FLW 32 tributary & $374347-0920517$ & Charcoal & 1.14 & $\mathrm{n}$ \\
\hline 8 & Pumping station spring & 374416 - 0920451 & Charcoal & .95 & $\mathbf{p}$ \\
\hline 9 & Stone Mill Spring & $374424-0920229$ & Charcoal & 2.99 & $\mathrm{n}$ \\
\hline 10 & Shanghai Spring & 374951 - 0920515 & Charcoal & 5.93 & $\mathbf{u}$ \\
\hline 11 & “Asphalt Plant" stream & $374303-0920456$ & Charcoal & 2.15 & $\mathrm{n}$ \\
\hline
\end{tabular}
any time, which indicates a good connection to underground fractures.

Attempted Recovery Sites

${ }^{a} p$, positive dye detection; $n$, no dye detected; $u$, uncertain (inconclusive results). 
Table 14. Summary for successful dye recovery at the pumping station spring during dye-trace test T103-07

\begin{tabular}{llll}
\hline Tracer injection date: & $\mathbf{0 7 - 1 3 - 9 5}$ & $\begin{array}{l}\text { Tracer Test No: } \\
\text { Project No: }\end{array}$ & $\begin{array}{l}\text { T103-07 } \\
\text { MO-10300 }\end{array}$ \\
& & Pros
\end{tabular}

Injection Site

$\begin{array}{llll}\text { Site name: } & \text { Sinkhole at junction of FLW 24 and FLW 22 } & \text { Latitude: } & 374442 \\ \text { County: } & \text { Pulaski } & \text { Longitude: } & 0920544 \\ \text { Quadrangle: } & \text { Big Piney } & \text { Land net: } & \text { sec. 24, T. 35 N, R. 11 W } \\ \text { Altitude: } & 1,010 \text { feet } & \text { Quarter section: } & \text { SE1/4 SW1/4 NW1/4; BCD }\end{array}$

Site description:

Field conditions:

Hydrologic conditions:

Tracing agent:

Agent quantity:

Time:
Large sinkhole at south side of junction of roads FLW 24 (pumping station) and FLW 22. Hot, humid, and sunny. No rainfall in the past week.

_. high-base flow; low-base flow; flood flow

$\begin{array}{ll}\text { Pre-injection flush: } & 300 \text { gallons } \\ \text { Post-injection flush: } & 700 \text { gallons } \\ \text { Investigator(s): } & \text { Brenden }\end{array}$

\section{Recovery Site}

Site name:

County:

Quadrangle:

Altitude:

Sampling method:

Analytical method:
Pumping station spring

Pulaski

Big Piney

825 feet

Activated coconut charcoal
Scanning spectrofluorophotometer
Latitude:

Longitude:

Land net:

Quarter section:

Trace length:

Travel time:
374416

0920451

sec. 24, T. $35 \mathrm{~N}$, R. $11 \mathrm{~W}$ SE1/4 SE1/4 SE1/4; CCC

File names of the sequence of traces indicating a positive dye recovery

$\begin{array}{lll}19950630.07 & 19950706.08 & 19950714.08 \\ 19950721.08 & 19950728.08 & 19950804.08 \\ 19950811.08 & 19950818.08 & 19950825.08\end{array}$

Remarks: Fluorescein has always been present in the background at this recovery site. The background fluorescein may be derived from residential areas 1 mile west of the spring. Dye recovery was within 1 to 8 days after injection. Initial recovery concentrations were large, indicating a well-defined flow path. Substantial dye concentrations were also detected after the peak concentration, indicating some water is flowing through alternate paths or is temporarily retained in storage. Flow rate along path carrying greatest dye load is less than 1 mile per day. 
Table 15. Summary for uncertain dye recovery at Shanghai Spring during dye-trace test T103-07

\begin{tabular}{|c|c|c|c|}
\hline Tracer injection date: & 07-13-95 & $\begin{array}{l}\text { Tracer Test No: } \\
\text { Project No: }\end{array}$ & $\begin{array}{l}\text { T103-07 } \\
\text { MO-10300 }\end{array}$ \\
\hline \multicolumn{4}{|c|}{ Injection Site } \\
\hline $\begin{array}{l}\text { Site name: } \\
\text { County: } \\
\text { Quadrangle: } \\
\text { Altitude: }\end{array}$ & $\begin{array}{l}\text { Sinkhole at junction of FLW } 24 \text { and FLW } 22 \\
\text { Pulaski } \\
\text { Big Piney } \\
1,010 \text { feet }\end{array}$ & $\begin{array}{l}\text { Latitude: } \\
\text { Longitude: } \\
\text { Land net: } \\
\text { Quarter section: }\end{array}$ & $\begin{array}{l}374442 \\
0920544 \\
\text { sec. } 24, \text { T. } 35 \text { N, R. } 11 \mathrm{~W} \\
\text { SE1/4 SW1/4 NW1/4; BCD }\end{array}$ \\
\hline $\begin{array}{l}\text { Site description: } \\
\text { Field conditions: } \\
\text { Hydrologic conditions: }\end{array}$ & \multicolumn{3}{|c|}{$\begin{array}{l}\text { Large sinkhole at south side of junction of roads FLW } 24 \text { (pumping station) and FLW } 22 . \\
\text { Hot, humid, and sunny. No rainfall in the past week. } \\
\text { _x_ low flow; _ high flow; _ high-base flow; _ low-base flow; _ flood flow }\end{array}$} \\
\hline $\begin{array}{l}\text { Tracing agent: } \\
\text { Agent quantity: } \\
\text { Time: }\end{array}$ & $\begin{array}{l}\text { Fluorescein } \\
0.50 \mathrm{lb} \\
10: 20 \text { p.m. }\end{array}$ & $\begin{array}{l}\text { Pre-injection flush: } \\
\text { Post-injection flush: } \\
\text { Investigator(s): }\end{array}$ & $\begin{array}{l}300 \text { gallons } \\
700 \text { gallons } \\
\text { Brenden }\end{array}$ \\
\hline \multicolumn{4}{|c|}{ Recovery Site } \\
\hline $\begin{array}{l}\text { Site name: } \\
\text { County: } \\
\text { Quadrangle: } \\
\text { Altitude: }\end{array}$ & $\begin{array}{l}\text { Shanghai Spring } \\
\text { Pulaski } \\
\text { Devils Elbow } \\
715 \text { feet }\end{array}$ & $\begin{array}{l}\text { Latitude: } \\
\text { Longitude: } \\
\text { Land net: } \\
\text { Quarter section: }\end{array}$ & $\begin{array}{l}374951 \\
0920515 \\
\text { sec. 24, T. 36 N, R. 11 W } \\
\text { NE1/4 NE1/4 SW1/4; CAA }\end{array}$ \\
\hline $\begin{array}{l}\text { Sampling method: } \\
\text { Analytical method: }\end{array}$ & $\begin{array}{l}\text { Activated coconut charcoal } \\
\text { Scanning spectrofluorophotometer }\end{array}$ & $\begin{array}{l}\text { Trace length: } \\
\text { Travel time: }\end{array}$ & $\begin{array}{l}5.93 \text { miles } \\
--\end{array}$ \\
\hline \multicolumn{4}{|c|}{ File names of the sequence of traces indicating a positive dye recovery } \\
\hline & $\begin{array}{l}19950630 \\
19950721 \\
19950811\end{array}$ & $\begin{array}{l}199507 \\
199508 \\
199508\end{array}$ & \\
\hline
\end{tabular}

Remarks: A small fluorescein peak was observed at Shanghai Spring several days after the successful recovery at the pumping station spring. Because dye concentrations at Shanghai Spring were substantial immediately before injection, it is not certain that the peak dye concentration detected 1 to 8 days after injection of dye into the sinkhole at roads FLW 24 and 22 was caused by the injected dye. This dye-trace test could be repeated using a different injected dye or larger quantity of fluorescein dye to confirm recovery at Shanghai Spring. 
Table 16. Discharge measurements and selected physical properties for the Big Piney River, Roubidoux Creek, and tributaries, December 1994

[mi, mile; $\mathrm{ft}^{3} / \mathrm{s}$, cubic feet per second; $\mu \mathrm{S} / \mathrm{cm}$, microsiemens per centimeter at 25 degrees Celsius; temp., temperature; ${ }^{\circ} \mathrm{C}$, degrees Celsius; $\mathrm{N} / \mathrm{A}$, not applicable; lb, left bank; --, no data; rb, right bank; see 1a, see measurement no. 1a; e, estimated; <, less than]

\begin{tabular}{|c|c|c|c|c|c|c|c|c|c|}
\hline $\begin{array}{c}\text { Measure- } \\
\text { ment } \\
\text { number }\end{array}$ & Stream name & Tributary name & Bank & $\begin{array}{l}\text { Distance } \\
\text { from } \\
\text { mouth } \\
\text { (ml) }\end{array}$ & $\begin{array}{c}\text { Date } \\
\text { (month- } \\
\text { day- } \\
\text { year) }\end{array}$ & $\begin{array}{c}\text { Flow } \\
\text { rate } \\
\left(\mathrm{ft}^{3} / \mathrm{s}\right)\end{array}$ & $\begin{array}{c}\text { Speclfic } \\
\text { conduct- } \\
\text { ance } \\
(\mu S / \mathrm{cm})\end{array}$ & $\begin{array}{c}\text { Temp. } \\
\left({ }^{\circ} \mathrm{C}\right)\end{array}$ & $\begin{array}{c}\text { Remark or } \\
\text { measure- } \\
\text { ment } \\
\text { rating }\end{array}$ \\
\hline 1 & Big Piney River & N/A & & 0.081 & $12-14-94$ & 506 & 333 & 6.0 & -- \\
\hline 2 & Big Piney tributary & unnamed & $\mathrm{lb}$ & .381 & $12-14-94$ & 0 & -- & -- & -- \\
\hline 3 & Big Piney tributary & unnamed & $\mathrm{lb}$ & .895 & $12-14-94$ & 0 & -- & - & - \\
\hline 4 & Big Piney tributary & unnamed & $\mathrm{rb}$ & 1.414 & $12-14-94$ & .27 & 448 & 9.7 & -- \\
\hline 5 & Big Piney River & N/A & & 1.495 & $12-14-94$ & 544 & 334 & 5.8 & -- \\
\hline 6 & Big Piney tributary & unnamed & $\mathrm{rb}$ & 1.578 & $12-14-94$ & 0 & -- & -- & -- \\
\hline 7 & Big Piney tributary & unnamed & lb & 1.619 & $12-14-94$ & 0 & -- & -- & -- \\
\hline 8 & Big Piney tributary & unnamed & $\mathrm{rb}$ & 1.757 & $12-14-94$ & 0 & -- & -- & -- \\
\hline 9 & Big Piney tributary & unnamed & $\mathrm{lb}$ & 2.646 & $12-14-94$ & .09 & 539 & 4.9 & -- \\
\hline 10 & Big Piney tributary & unnamed & lb & 2.994 & $12-14-94$ & 0 & -- & -- & -- \\
\hline 11 & Big Piney tributary & unnamed & $\mathrm{rb}$ & 3.007 & $12-14-94$ & 0 & -- & -- & -- \\
\hline 12 & Big Piney tributary & unnamed & $\mathrm{rb}$ & 3.083 & $12-14-94$ & 0 & -- & -- & -- \\
\hline 13 & Big Piney tributary & unnamed & $\mathrm{lb}$ & 3.272 & $12-14-94$ & 0 & -- & -- & -- \\
\hline 14 & Big Piney tributary & unnamed & $\mathrm{rb}$ & 3.513 & $12-14-94$ & 0 & -- & -- & -- \\
\hline 15 & Big Piney tributary & unnamed & $\mathrm{rb}$ & 3.961 & $12-14-94$ & 0 & -- & -- & -- \\
\hline 16 & Big Piney tributary & unnamed & $\mathrm{rb}$ & 4.055 & $12-14-94$ & .15 & 343 & 7.9 & -- \\
\hline 17 & Big Piney tributary & unnamed & lb & 4.469 & $12-14-94$ & 0 & -- & -- & -- \\
\hline 18 & Big Piney River & N/A & & 4.853 & $12-14-94$ & 535 & 324 & 5.8 & -- \\
\hline 19 & Big Piney tributary & unnamed & $\mathrm{rb}$ & 4.970 & $12-14-94$ & .02 & 364 & 6.0 & -- \\
\hline 20 & Big Piney tributary & unnamed & $\mathrm{rb}$ & 5.081 & $12-14-94$ & 0 & -- & -- & -- \\
\hline 21 & Big Piney tributary & unnamed & lb & 5.594 & $12-14-94$ & 0 & -- & -- & -- \\
\hline 22 & Big Piney tributary & Shanghai Spring & $\mathrm{lb}$ & 5.925 & $12-14-94$ & 22.2 & 424 & 14.0 & -- \\
\hline 23 & Big Piney tributary & Dry Creek & $\mathrm{lb}$ & 6.464 & $12-14-94$ & 0 & -- & -- & -- \\
\hline 24 & Big Piney tributary & unnamed & $\mathrm{rb}$ & 6.483 & $12-14-94$ & 0 & -- & -- & -- \\
\hline 25 & Big Piney tributary & unnamed & $\mathrm{lb}$ & 6.698 & $12-14-94$ & 0 & -- & -- & -- \\
\hline 26 & Big Piney tributary & unnamed & $\mathrm{rb}$ & 7.022 & $12-14-94$ & 0 & -- & -- & -- \\
\hline 27 & Big Piney tributary & unnamed & rb & 7.627 & $12-14-94$ & 0 & -- & -- & -- \\
\hline 28 & Big Piney River & N/A & & 8.060 & $12-14-94$ & 520 & 334 & 5.3 & -- \\
\hline 29 & Big Piney tributary & unnamed & $\mathrm{lb}$ & 8.161 & $12-14-94$ & 0 & -- & -- & -- \\
\hline 30 & Big Piney tributary & unnamed & $\mathrm{rb}$ & 8.485 & $12-14-94$ & .04 & 491 & 6.8 & -- \\
\hline 31 & Big Piney tributary & unnamed & rb & 9.058 & $12-14-94$ & 0 & -- & -- & -- \\
\hline 32 & Big Piney tributary & unnamed & lb & 10.132 & $12-14-94$ & 0 & -- & -- & -- \\
\hline 33 & Big Piney tributary & unnamed & lb & 10.766 & $12-14-94$ & 0 & -- & -- & -- \\
\hline 34 & Big Piney tributary & unnamed & lb & 11.116 & $12-14-94$ & 0 & -- & -- & -- \\
\hline 35 & Big Piney tributary & unnamed & lb & 11.592 & $12-14-94$ & 0 & -- & -- & -- \\
\hline 36 & Big Piney tributary & unnamed & lb & 11.872 & $12-14-94$ & 0 & -- & -- & -- \\
\hline 37 & Big Piney tributary & unnamed & lb & 12.603 & $12-14-94$ & 0 & -- & -- & -- \\
\hline 38 & Big Piney River & N/A & & 12.676 & $12-14-94$ & 532 & 324 & 6.3 & -- \\
\hline 39 & Big Piney tributary & unnamed & lb & 13.015 & $12-14-94$ & 0 & -- & -- & -- \\
\hline 40 & Big Piney tributary & unnamed & rb & 13.557 & $12-14-94$ & 0 & -- & -- & -- \\
\hline 41 & Big Piney tributary & unnamed & lb & 13.896 & $12-14-94$ & 0 & -- & -- & -- \\
\hline 42 & Big Piney tributary & Ousley Spring & $\mathrm{rb}$ & 14.062 & $12-14-94$ & .75 & 465 & 12.9 & -- \\
\hline 43 & Big Piney tributary & unnamed spring & $\mathrm{rb}$ & 14.139 & $12-14-94$ & 1.11 & 441 & 11.2 & -- \\
\hline 44 & Big Piney tributary & unnamed & $\mathrm{rb}$ & 15.112 & $12-14-94$ & 0 & -- & -- & -- \\
\hline 45 & Big Piney River & N/A & & 15.165 & $12-14-94$ & 504 & 334 & 5.1 & -- \\
\hline 46 & Big Piney tributary & unnamed & $\mathrm{lb}$ & 15.481 & $12-13-94$ & 0 & -- & -- & -- \\
\hline
\end{tabular}


Table 16. Discharge measurements and selected physical properties for the Big Piney River, Roubidoux Creek, and tributaries, December 1994-Continued

\begin{tabular}{|c|c|c|c|c|c|c|c|c|c|}
\hline $\begin{array}{c}\text { Measure- } \\
\text { ment } \\
\text { number }\end{array}$ & Stream name & Tributary name & Bank & $\begin{array}{c}\text { Distance } \\
\text { from } \\
\text { mouth } \\
\text { (ml) }\end{array}$ & $\begin{array}{c}\text { Date } \\
\text { (month- } \\
\text { day- } \\
\text { year) }\end{array}$ & $\begin{array}{c}\text { Flow } \\
\text { rate } \\
\left(\mathrm{ft}^{3} / \mathrm{s}\right)\end{array}$ & $\begin{array}{c}\text { Specific } \\
\text { conduct- } \\
\text { ance } \\
(\mu S / \mathrm{cm})\end{array}$ & $\begin{array}{c}\text { Temp. } \\
\left({ }^{\circ} \mathrm{C}\right)\end{array}$ & $\begin{array}{c}\text { Remark or } \\
\text { measure- } \\
\text { ment } \\
\text { rating }\end{array}$ \\
\hline 47 & Big Piney tributary & Smokey Hollow & $\mathrm{rb}$ & 16.217 & $12-13-94$ & 0 & -- & - & -- \\
\hline 48 & Big Piney tributary & unnamed & rb & 16.381 & $12-13-94$ & 0 & -- & -- & -- \\
\hline 49 & Big Piney tributary & spring branch & rb & 16.702 & $12-14-94$ & .04 & 501 & 5.2 & -- \\
\hline 50 & Big Piney tributary & Spring Creek & rb & 16.829 & $12-13-94$ & 38.4 & 308 & 10.0 & -- \\
\hline 51 & Big Piney tributary & unnamed & $\mathrm{rb}$ & 17.276 & $12-13-94$ & 0 & -- & -- & -- \\
\hline 52 & Big Piney tributary & unnamed & $\mathrm{rb}$ & 17.588 & $12-13-94$ & 0 & -- & - & -- \\
\hline 53 & Big Piney River & N/A & & 17.763 & $12-13-94$ & 518 & 228 & 6.1 & $\cdots$ \\
\hline 54 & Big Piney tributary & unnamed & lb & 19.740 & & see 1a & -- & -- & -- \\
\hline 55 & Big Piney tributary & unnamed & $\mathrm{rb}$ & 19.850 & $12-13-94$ & 0 & -- & -- & -- \\
\hline 56 & Big Piney River & N/A & & 20.886 & $12-13-94$ & 407 & 321 & 10.0 & -- \\
\hline 57 & Big Piney tributary & Stone Mill spring & rb & 21.393 & $12-13-94$ & 46.8 & 270 & 13.7 & -- \\
\hline 58 & Big Piney tributary & unnamed & rb & 21.852 & $12-13-94$ & 0 & -- & -- & -- \\
\hline 59 & Big Piney tributary & unnamed & $\mathrm{rb}$ & 22.179 & $12-13-94$ & 0 & -- & -- & -- \\
\hline 60 & Big Piney tributary & unnamed & $\mathrm{rb}$ & 22.428 & $12-13-94$ & 0 & -- & -- & -- \\
\hline 61 & Big Piney tributary & unnamed & rb & 22.849 & $12-13-94$ & 0 & -- & -- & -- \\
\hline 62 & Big Piney tributary & unnamed & $\mathrm{rb}$ & 23.213 & $12-13-94$ & 0 & -- & -- & -- \\
\hline 63 & Big Piney River & N/A & & 23.679 & $12-13-94$ & 453 & 318 & 5.4 & - \\
\hline 64 & Big Piney tributary & pump station culvert & lb & 23.985 & $12-13-94$ & .12 & 385 & 12.0 & -- \\
\hline 65 & Big Piney tributary & unnamed & lb & 24.120 & & see $6 a$ & -- & -- & -- \\
\hline 66 & Big Piney tributary & unnamed & $\mathrm{lb}$ & 24.402 & & see $9 a$ & -- & -- & -- \\
\hline 67 & Big Piney tributary & unnamed & lb & 24.545 & $12-13-94$ & .06 & 419 & 2.5 & -- \\
\hline 68 & Big Piney tributary & unnamed & lb & 25.319 & $12-13-94$ & 0 & - & -- & - \\
\hline 69 & Big Piney River & N/A & & 25.424 & $12-13-94$ & 441 & 336 & 5.0 & -- \\
\hline 70 & Big Piney tributary & unnamed & lb & 25.709 & $12-13-94$ & 0 & -- & -- & -- \\
\hline 71 & Big Piney tributary & unnamed & $\mathrm{rb}$ & 26.992 & $12-13-94$ & 0 & -- &.- & -- \\
\hline 72 & Big Piney tributary & unnamed & rb & 28.203 & $12-13-94$ & 0 & -- & -- & -- \\
\hline 73 & Big Piney tributary & Miller Spring & lb & 28.605 & $12-12-94$ & 9.06 & 308 & 13.0 & -- \\
\hline 74 & Big Piney tributary & McCourtney Hollow & 16 & 28.930 & $12-13-94$ & 0 & -- & -- & -- \\
\hline 75 & Big Piney tributary & unnamed & rb & 29.403 & $12-13-94$ & 0 & -- & -- & -- \\
\hline 76 & Big Piney River & N/A & & 29.495 & $12-13-94$ & 470 & -- & -- & -- \\
\hline 77 & Big Piney River & N/A & & 29.495 & $12-13-94$ & 467 & 335 & 4.5 & -- \\
\hline 78 & Big Piney tributary & unnamed & rb & 29.557 & $12-12-94$ & 0 & - & - & -- \\
\hline 79 & Big Piney tributary & unnamed & $\mathrm{lb}$ & 29.587 & $12-12-94$ & 0 & -- & - & -- \\
\hline 80 & Big Piney tributary & unnamed & $\mathrm{lb}$ & 29.971 & $12-12-94$ & 0 & -- & -- & - \\
\hline 81 & Big Piney tributary & unnamed & rb & 30.831 & $12-12-94$ & 0 & -- & -- & -- \\
\hline 82 & Big Piney tributary & unnamed & $\mathrm{lb}$ & 31.259 & $12-12-94$ & 0 & -- & -- & -- \\
\hline 83 & Big Piney tributary & unnamed & $\mathrm{rb}$ & 31.588 & $12-12-94$ & 0 & -- & - & - \\
\hline 84 & Big Piney tributary & unnamed & rb & 31.895 & $12-12-94$ & .02 & 478 & 4.5 & -- \\
\hline 85 & Big Piney River & N/A & & 32.367 & $12-12-94$ & 523 & 341 & 6.0 & -- \\
\hline 86 & Big Piney tributary & unnamed & rb & 32.730 & $12-12-94$ & 0 & -- & - & -- \\
\hline 87 & Big Piney tributary & unnamed & $1 \mathrm{~b}$ & 33.462 & $12-12-94$ & .03 & 331 & 2.4 & -- \\
\hline 88 & Big Piney tributary & unnamed & $\mathrm{rb}$ & 33.615 & $12-12-94$ & 0 & -- & -- & -- \\
\hline 89 & Big Piney tributary & unnamed & lb & 33.907 & & see $13 a$ & -- & $\cdots$ & -- \\
\hline 90 & Big Piney tributary & unnamed & lb & 35.872 & $12-12-94$ & .02 & 413 & 3.5 & -- \\
\hline 91 & Big Piney River & N/A & & 35.900 & $12-12-94$ & 445 & 342 & 5.2 & -- \\
\hline 92 & Big Piney River & N/A & & 35.900 & $12-12-94$ & 464 & 342 & 5.2 & -- \\
\hline 93 & Big Piney tributary & unnamed & lb & 35.934 & $12-12-94$ & .10 & 431 & 2.5 & -- \\
\hline 94 & Big Piney tributary & unnamed & lb & 36.435 & $12-12-94$ & 0 & -- & -- & -- \\
\hline
\end{tabular}


Table 16. Discharge measurements and selected physical properties for the Big Piney River, Roubidoux Creek, and tributaries, December 1994-Continued

\begin{tabular}{|c|c|c|c|c|c|c|c|c|c|}
\hline $\begin{array}{c}\text { Measure- } \\
\text { ment } \\
\text { number }\end{array}$ & Stream name & Trlbutary name & Bank & $\begin{array}{l}\text { Dlstance } \\
\text { from } \\
\text { mouth } \\
\text { (ml) }\end{array}$ & $\begin{array}{c}\text { Date } \\
\text { (month- } \\
\text { day- } \\
\text { year) }\end{array}$ & $\begin{array}{l}\text { Flow } \\
\text { rate } \\
\left(\mathrm{ft}^{3} / \mathrm{s}\right)\end{array}$ & $\begin{array}{c}\text { Speclfic } \\
\text { conduct- } \\
\text { ance } \\
(\mu S / c m)\end{array}$ & $\begin{array}{l}\text { Temp. } \\
\left({ }^{\circ} \mathrm{C}\right)\end{array}$ & $\begin{array}{c}\text { Remark or } \\
\text { measure- } \\
\text { ment } \\
\text { ratling }\end{array}$ \\
\hline 95 & Big Piney tributary & Crossing Hollow & $\mathrm{rb}$ & 37.311 & $12-12-94$ & 0.24 & 426 & 4.5 & -- \\
\hline 96 & Big Piney tributary & unnamed & $\mathrm{rb}$ & 37.588 & $12-12-94$ & 0 & -- & -- & -- \\
\hline 97 & Big Piney River & N/A & & 37.942 & $12-12-94$ & 482 & 324 & 5.1 & -- \\
\hline $1 \mathrm{a}$ & unnamed stream & N/A & & .066 & $12-21-94$ & .29 & 400 & 8.6 & -- \\
\hline $2 a$ & unnamed stream & N/A & & .332 & $12-21-94$ & .46 & -- & -- & -- \\
\hline $3 a$ & $\begin{array}{l}\text { unnamed stream } \\
\text { tributary }\end{array}$ & unnamed south fork & $\mathrm{rb}$ & .862 & & see $1 b$ & -- & -- & -- \\
\hline $4 a$ & unnamed stream & N/A & & 1.045 & $12-21-94$ & .29 & 500 & 9.1 & -- \\
\hline $5 a$ & unnamed stream & N/A & & 1.320 & $12-21-94$ & 0 & -- & -- & - \\
\hline $6 a$ & $\begin{array}{l}\text { "Pumping station" } \\
\text { stream }\end{array}$ & N/A & & .021 & $12-13-94$ & .12 & 444 & 5.7 & - \\
\hline $7 a$ & $\begin{array}{l}\text { "Pumping station" } \\
\text { stream }\end{array}$ & N/A & & .364 & $12-21-94$ & .26 & 440 & 11.2 & -- \\
\hline $8 a$ & $\begin{array}{l}\text { "Pumping station" } \\
\text { stream }\end{array}$ & N/A & & .526 & $12-21-94$ & 0 & - & -- & -- \\
\hline $9 a$ & unnamed stream & N/A & & .035 & $12-13-94$ & .11 & 356 & 6.4 & -- \\
\hline $10 a$ & unnamed stream & N/A & & .282 & $12-21-94$ & .30 & -- & -- & -- \\
\hline $11 \mathrm{a}$ & $\begin{array}{l}\text { unnamed stream } \\
\text { tributary }\end{array}$ & unnamed tributary & $\mathrm{lb}$ & .662 & & see $2 b$ & - & - & - \\
\hline $12 a$ & unnamed stream & N/A & & .787 & $12-21-94$ & 0 & -- & -- & - \\
\hline $13 a$ & Bald Ridge Creek & N/A & & .043 & $12-12-94$ & 2.61 & 335 & 7.5 & -- \\
\hline $14 \mathrm{a}$ & Bald Ridge Creek & N/A & & .141 & $12-21-94$ & 3.07 & -- & -- & -- \\
\hline $15 \mathrm{a}$ & Bald Ridge Creek & N/A & & .502 & $12-21-94$ & 3.11 & $-\cdots$ & -- & -- \\
\hline $16 \mathrm{a}$ & Bald Ridge Creek & N/A & & 1.821 & $12-22-94$ & 2.84 & -- & -- & -- \\
\hline $17 \mathrm{a}$ & $\begin{array}{l}\text { Bald Ridge Creek } \\
\text { tributary }\end{array}$ & $\begin{array}{c}\text { Little Bald Ridge } \\
\text { Creek }\end{array}$ & lb & 1.832 & & see $3 b$ & - & -- & -- \\
\hline $18 \mathrm{a}$ & $\begin{array}{l}\text { Bald Ridge Creek } \\
\text { tributary }\end{array}$ & unnamed & $\mathrm{lb}$ & 2.945 & $12-22-94$ & 0 & -- & -- & -- \\
\hline $19 a$ & $\begin{array}{l}\text { Bald Ridge Creek } \\
\text { tributary }\end{array}$ & unnamed & $\mathrm{lb}$ & 3.173 & $12-22-94$ & 0 & -- & -- & -- \\
\hline $20 a$ & Bald Ridge Creek & N/A & & 3.786 & $12-22-94$ & .53 & -- & -- & -- \\
\hline $21 a$ & Bald Ridge Creek & N/A & & 4.712 & $12-22-94$ & 0 & -- & -- & flow begins \\
\hline $22 a$ & $\begin{array}{l}\text { Bald Ridge Creek } \\
\text { tributary }\end{array}$ & unnamed & $\mathrm{rb}$ & 5.221 & $12-22-94$ & 0 & -- & -- & -- \\
\hline $23 a$ & $\begin{array}{l}\text { Bald Ridge Creek } \\
\text { tributary }\end{array}$ & unnamed & lb & 5.662 & $12-22-94$ & 0 & - & -- & -- \\
\hline $24 a$ & Bald Ridge Creek & N/A & & 6.405 & $12-22-94$ & 0 & -- & - & -- \\
\hline $1 b$ & $\begin{array}{l}\text { unnamed south } \\
\text { fork }\end{array}$ & N/A & rb & .153 & $12-21-94$ & 0 & -- & $-\cdots$ & -- \\
\hline $2 b$ & unnamed tributary & N/A & & .145 & $12-21-94$ & 0 & -- & -- & -. \\
\hline $3 b$ & $\begin{array}{l}\text { Little Bald Ridge } \\
\text { Creek tributary }\end{array}$ & Falls Hollow & lb & .277 & & see $1 c$ & -- & -. & -- \\
\hline $4 b$ & $\begin{array}{l}\text { Little Bald Ridge } \\
\text { Creek }\end{array}$ & N/A & & .606 & $12-21-94$ & .78 & -- & - & - \\
\hline $5 b$ & $\begin{array}{c}\text { Little Bald Ridge } \\
\text { Creek tributary }\end{array}$ & unnamed spring & rb & 1.332 & $12-22-94$ & 0 & - & -- & -- \\
\hline $6 \mathrm{~b}$ & $\begin{array}{l}\text { Little Bald Ridge } \\
\text { Creek tributary }\end{array}$ & N/A & $\mathrm{lb}$ & 1.916 & $12-22-94$ & 0 & - & - & -- \\
\hline $7 b$ & $\begin{array}{c}\text { Little Bald Ridge } \\
\text { Creek tributary }\end{array}$ & $\begin{array}{l}\text { Wildcat Hollow } \\
\text { spring }\end{array}$ & rb & 2.197 & $12-22-94$ & 0 & - & -- & -- \\
\hline
\end{tabular}


Table 16. Discharge measurements and selected physical properties for the Big Piney River, Roubidoux Creek, and tributaries, December 1994-Continued

\begin{tabular}{|c|c|c|c|c|c|c|c|c|c|}
\hline $\begin{array}{c}\text { Measure- } \\
\text { ment } \\
\text { number }\end{array}$ & Stream name & Trlbutary name & Bank & $\begin{array}{l}\text { Distance } \\
\text { from } \\
\text { mouth } \\
(\mathrm{ml})\end{array}$ & $\begin{array}{c}\text { Date } \\
\text { (month- } \\
\text { day- } \\
\text { year) }\end{array}$ & $\begin{array}{c}\text { Flow } \\
\text { rate } \\
\left(\mathrm{ft}^{3} / \mathrm{s}\right)\end{array}$ & $\begin{array}{c}\text { Specific } \\
\text { conduct- } \\
\text { ance } \\
(\mu \mathrm{S} / \mathrm{cm})\end{array}$ & $\begin{array}{l}\text { Temp. } \\
\left({ }^{\circ} \mathrm{C}\right)\end{array}$ & $\begin{array}{c}\text { Remark or } \\
\text { measure- } \\
\text { ment } \\
\text { rating }\end{array}$ \\
\hline $1 \mathrm{c}$ & $\begin{array}{l}\text { Falls Hollow } \\
\text { tributary }\end{array}$ & unnamed & $\mathrm{lb}$ & 0.023 & $12-22-94$ & 0 & -- & $\overline{--}$ & $\overline{--}$ \\
\hline $2 c$ & Falls Hollow & N/A & & .138 & $12-22-94$ & 0 & -- & -- & -- \\
\hline 1 & Roubidoux Creek & N/A & & .136 & $12-13-94$ & 63.4 & 241 & 10.9 & -- \\
\hline 2 & Roubidoux Creek & N/A & & 1.417 & $12-13-94$ & 64.3 & 365 & 11.7 & good \\
\hline 3 & Roubidoux Creek & N/A & & 1.861 & $12-13-94$ & 65.1 & 400 & 11.3 & -- \\
\hline 4 & $\begin{array}{l}\text { Roubidoux Creek } \\
\text { tributary }\end{array}$ & sewage plant outflow & $\mathrm{rb}$ & 1.889 & $12-13-94$ & .61 & 825 & 8.3 & poor \\
\hline 5 & Roubidoux Creek & N/A & & 2.493 & $12-13-94$ & 58.3 & 365 & 12.0 & good \\
\hline 6 & $\begin{array}{l}\text { Roubidoux Creek } \\
\text { tributary }\end{array}$ & Roubidoux Spring & rb & 2.928 & $12-13-94$ & 61.2 & 351 & 12.8 & - \\
\hline 7 & Roubidoux Creek & N/A & & 3.565 & $12-13-94$ & 1.89 & 385 & 5.7 & fair \\
\hline 8 & $\begin{array}{l}\text { Roubidoux Creek } \\
\text { tributary }\end{array}$ & unnamed & rb & 3.768 & $12-13-94$ & 0 & -- & -- & -- \\
\hline 9 & Roubidoux Creek & N/A & & 4.277 & $12-13-94$ & 1.02 & 375 & 4.8 & fair \\
\hline 10 & $\begin{array}{l}\text { Roubidoux Creek } \\
\text { tributary }\end{array}$ & Burchard Hollow & rb & 4.586 & $12-13-94$ & 0 & -- & -- & $\begin{array}{l}\text { pumping } \\
\text { at creek }\end{array}$ \\
\hline 11 & Roubidoux Creek & N/A & & 4.767 & $12-13-94$ & 1.43 & 333 & 6.2 & good \\
\hline 12 & $\begin{array}{l}\text { Roubidoux Creek } \\
\text { tributary }\end{array}$ & unnamed & lb & 5.447 & $12-13-94$ & 0 & -- & -- & -- \\
\hline 13 & Roubidoux Creek & N/A & & 6.116 & $12-13-94$ & .28 & 350 & 6.2 & -- \\
\hline 14 & Roubidoux Creek & N/A & & 6.546 & $12-13-94$ & .36 & 332 & 4.4 & fair/poor \\
\hline 15 & Roubidoux Creek & N/A & & 7.086 & $12-13-94$ & .29 & 356 & 4.7 & good \\
\hline 16 & Roubidoux Creek & N/A & & 7.514 & $12-13-94$ & .67 & 357 & 6.0 & fair \\
\hline 17 & Roubidoux Creek & N/A & & 7.514 & $12-13-94$ & .66 & 295 & 5.5 & poor \\
\hline 18 & Roubidoux Creek & N/A & & 7.929 & $12-13-94$ & .83 & 372 & 5.5 & poor \\
\hline 19 & Roubidoux Creek & N/A & & 8.250 & $12-13-94$ & .31 & 357 & 7.4 & fair/poor \\
\hline 20 & $\begin{array}{l}\text { Roubidoux Creek } \\
\text { tributary }\end{array}$ & Ballard Hollow & $\mathrm{rb}$ & 8.350 & & see $1 \mathrm{a}$ & -- & -- & -- \\
\hline 21 & $\begin{array}{l}\text { Roubidoux Creek } \\
\text { tributary }\end{array}$ & unnamed & rb & 8.654 & $12-13-94$ & 0 & -- & -- & -- \\
\hline 22 & Roubidoux Creek & N/A & & 8.769 & $12-13-94$ & 0 & -- & - & -- \\
\hline 23 & Roubidoux Creek & N/A & & 8.893 & $12-13-94$ & 0 & -- & -- & - \\
\hline 24 & Roubidoux Creek & N/A & & 9.338 & $12-13-94$ & $.03 \mathrm{e}$ & -- & -- & -- \\
\hline 25 & Roubidoux Creek & N/A & & 9.565 & $12-13-94$ & 0 & -- & -- & -- \\
\hline 26 & Roubidoux Creek & N/A & & 9.830 & $12-13-94$ & $\mathbf{0}$ & -- & -- & -- \\
\hline 27 & $\begin{array}{l}\text { Roubidoux Creek } \\
\text { tributary }\end{array}$ & unnamed & lb & 10.882 & $12-13-94$ & 0 & $-\cdot$ & -- & - \\
\hline 28 & Roubidoux Creek & N/A & & 11.244 & $12-13-94$ & 0 & -- & -- & -- \\
\hline 29 & $\begin{array}{l}\text { Roubidoux Creek } \\
\text { tributary }\end{array}$ & unnamed & rb & 11.862 & $12-13-94$ & 0 & -- & -- & -- \\
\hline 30 & Roubidoux Creek & N/A & & 11.943 & $12-13-94$ & 0 & -- & - & -- \\
\hline 31 & Roubidoux Creek & N/A & & 12.184 & $12-13-94$ & 0 & -- & -- & -- \\
\hline 32 & $\begin{array}{c}\text { Roubidoux Creek } \\
\text { (Highway H) }\end{array}$ & N/A & & 12.921 & $12-13-94$ & 0 & -- & -- & -- \\
\hline 33 & $\begin{array}{l}\text { Roubidoux Creek } \\
\text { tributary }\end{array}$ & unnamed & lb & 13.447 & $12-13-94$ & 0 & -- & -- & - \\
\hline 34 & $\begin{array}{l}\text { Roubidoux Creek } \\
\text { tributary }\end{array}$ & Town Hollow & lb & 13.832 & $12-13-94$ & 0 & -- & -- & -- \\
\hline 35 & Roubidoux Creek & N/A & & 14.088 & $12-13-94$ & 0 & -- & -- & -- \\
\hline
\end{tabular}


Table 16. Discharge measurements and selected physical properties for the Big Piney River, Roubidoux Creek, and tributaries, December 1994-Continued

\begin{tabular}{|c|c|c|c|c|c|c|c|c|c|}
\hline $\begin{array}{c}\text { Measure- } \\
\text { ment } \\
\text { number }\end{array}$ & Stream name & Trlbutary name & Bank & $\begin{array}{l}\text { Distance } \\
\text { from } \\
\text { mouth } \\
\text { (ml) }\end{array}$ & $\begin{array}{c}\text { Date } \\
\text { (month- } \\
\text { day- } \\
\text { year) }\end{array}$ & $\begin{array}{l}\text { Flow } \\
\text { rate } \\
\left(\mathrm{ft}^{3} / \mathrm{s}\right)\end{array}$ & $\begin{array}{l}\text { Specific } \\
\text { conduct- } \\
\text { ance } \\
(\mu \mathrm{S} / \mathrm{cm})\end{array}$ & $\begin{array}{l}\text { Temp. } \\
\left({ }^{\circ} \mathrm{C}\right)\end{array}$ & $\begin{array}{c}\text { Remark or } \\
\text { measure- } \\
\text { ment } \\
\text { rating }\end{array}$ \\
\hline 36 & Roubidoux Creek & N/A & & 14.287 & $12-13-94$ & 0 & -- & -- & -- \\
\hline 37 & Roubidoux Creek & N/A & & 14.498 & $12-13-94$ & 0 & -- & -- & -- \\
\hline 38 & $\begin{array}{l}\text { Roubidoux Creek } \\
\text { tributary }\end{array}$ & York Hollow & $\mathrm{lb}$ & 14.574 & $12-13-94$ & 0 & -- & - & -- \\
\hline 39 & $\begin{array}{l}\text { Roubidoux Creek } \\
\text { tributary }\end{array}$ & unnamed & $\mathrm{Ib}$ & 14.928 & $12-13-94$ & 0 & -- & -- & -- \\
\hline 40 & $\begin{array}{l}\text { Roubidoux Creek } \\
\text { tributary }\end{array}$ & Elliot Branch & lb & 15.322 & $12-13-94$ & 0 & -- & -- & -- \\
\hline 41 & Roubidoux Creek & N/A & & 15.551 & $12-13-94$ & 0 & - & -- & - \\
\hline 42 & Roubidoux Creek & N/A & & 16.973 & $12-13-94$ & 0 & -- & -- & -- \\
\hline 43 & Roubidoux Creek & N/A & & 17.433 & $12-13-94$ & 0 & -- & -- & -- \\
\hline 44 & $\begin{array}{l}\text { Roubidoux Creek } \\
\text { tributary }\end{array}$ & unnamed & $\mathrm{rb}$ & 17.641 & $12-13-94$ & 0 & -- & -- & - \\
\hline 45 & $\begin{array}{l}\text { Roubidoux Creek } \\
\text { tributary }\end{array}$ & Hurd Hollow & $\mathrm{rb}$ & 19.251 & $12-13-94$ & 0 & - & -- & -- \\
\hline 46 & Roubidoux Creek & N/A & & 21.729 & $12-13-94$ & 0 & -- & -- & -- \\
\hline 47 & Roubidoux Creek & N/A & & 21.733 & $12-13-94$ & .46 & 361 & 1.8 & -- \\
\hline 48 & Roubidoux Creek & N/A & & 21.776 & $12-13-94$ & 0 & -- & -- & -- \\
\hline 49 & $\begin{array}{l}\text { Roubidoux Creek } \\
\text { tributary }\end{array}$ & unnamed & $\mathrm{lb}$ & 22.013 & $12-13-94$ & 0 & -- & -- & -- \\
\hline 50 & Roubidoux Creek & N/A & & 22.039 & $12-13-94$ & 3.10 & 361 & 2.3 & -- \\
\hline 51 & Roubidoux Creek & N/A & & 22.158 & $12-14-94$ & 3.55 & 363 & 4.3 & good/fair \\
\hline 52 & $\begin{array}{l}\text { Roubidoux Creek } \\
\text { tributary }\end{array}$ & unnamed & $\mathrm{lb}$ & 22.196 & $12-14-94$ & 0 & -- & -- & -- \\
\hline 53 & $\begin{array}{l}\text { Roubidoux Creek } \\
\text { tributary }\end{array}$ & unnamed & $\mathrm{lb}$ & 22.639 & $12-14-94$ & 0 & - & -- & -- \\
\hline 54 & Roubidoux Creek & N/A & & 22.924 & $12-14-94$ & 28.2 & 363 & 4.1 & good \\
\hline 55 & Roubidoux Creek & N/A & & 23.765 & $12-14-94$ & 33.6 & 361 & 4.7 & good \\
\hline 56 & $\begin{array}{l}\text { Roubidoux Creek } \\
\text { tributary }\end{array}$ & unnamed & $\mathrm{lb}$ & 23.908 & $12-14-94$ & $.01 \mathrm{e}$ & -- & -- & -- \\
\hline 57 & $\begin{array}{l}\text { Roubidoux Creek } \\
\text { tributary }\end{array}$ & unnamed & $\mathrm{lb}$ & 24.267 & $12-14-94$ & 0 & -- & - & -- \\
\hline 58 & $\begin{array}{l}\text { Roubidoux Creek } \\
\text { tributary }\end{array}$ & unnamed & $\mathrm{lb}$ & 24.541 & $12-14-94$ & 0 & -- & -- & -- \\
\hline 59 & Roubidoux Creek & N/A & & 24.582 & $12-14-94$ & 40.0 & 364 & 4.3 & good \\
\hline 60 & $\begin{array}{l}\text { Roubidoux Creek } \\
\text { tributary }\end{array}$ & unnamed & $\mathrm{lb}$ & 24.606 & $12-14-94$ & 0 & -- & -- & -- \\
\hline 61 & $\begin{array}{l}\text { Roubidoux Creek } \\
\text { tributary }\end{array}$ & unnamed & $\mathrm{rb}$ & 25.257 & $12-14-94$ & 0 & -- & -- & - \\
\hline 62 & Roubidoux Creek & N/A & & 25.459 & $12-14-94$ & 43.2 & 366 & 4.2 & good \\
\hline 63 & Roubidoux Creek & N/A & & 25.886 & $12-14-94$ & 46.0 & 355 & 4.3 & good/fair \\
\hline 64 & $\begin{array}{l}\text { Roubidoux Creek } \\
\text { tributary }\end{array}$ & unnamed & $\mathrm{rb}$ & 25.893 & $12-14-94$ & $.01 \mathrm{e}$ & -- & -- & -- \\
\hline 65 & $\begin{array}{l}\text { Roubidoux Creek } \\
\text { tributary }\end{array}$ & unnamed & rb & 26.230 & $12-14-94$ & 0 & -- & -- & -- \\
\hline 66 & Roubidoux Creek & N/A & & 26.418 & $12-14-94$ & 41.7 & 308 & 3.9 & good \\
\hline 67 & Roubidoux Creek & N/A & & 26.418 & $12-12-94$ & 44.0 & 360 & 5.5 & good \\
\hline 68 & $\begin{array}{l}\text { Roubidoux Creek } \\
\text { tributary }\end{array}$ & unnamed & $\mathrm{rb}$ & 26.887 & $12-12-94$ & 0 & -- & -- & -- \\
\hline
\end{tabular}


Table 16. Discharge measurements and selected physical properties for the Big Piney River, Roubidoux Creek, and tributaries, December 1994-Continued

\begin{tabular}{|c|c|c|c|c|c|c|c|c|c|}
\hline $\begin{array}{c}\text { Measure- } \\
\text { ment } \\
\text { number }\end{array}$ & Stream name & Trlbutary name & Bank & $\begin{array}{l}\text { Distance } \\
\text { from } \\
\text { mouth } \\
\text { (ml) }\end{array}$ & $\begin{array}{c}\text { Date } \\
\text { (month- } \\
\text { day- } \\
\text { year) }\end{array}$ & $\begin{array}{c}\text { Flow } \\
\text { rate } \\
\left(\mathrm{ft}^{3} / \mathrm{s}\right)\end{array}$ & $\begin{array}{l}\text { Specific } \\
\text { conduct- } \\
\text { ance } \\
(\mu \mathrm{S} / \mathrm{cm})\end{array}$ & $\begin{array}{l}\text { Temp. } \\
\left({ }^{\circ} \mathrm{C}\right)\end{array}$ & $\begin{array}{c}\text { Remark or } \\
\text { measure- } \\
\text { ment } \\
\text { rating }\end{array}$ \\
\hline 69 & $\begin{array}{l}\text { Roubidoux Creek } \\
\text { tributary }\end{array}$ & unnamed & $\overline{l b}$ & 26.920 & $12-12-94$ & 0 & -- & - & -- \\
\hline 70 & Roubidoux Creek & N/A & & 27.148 & $12-12-94$ & 44.5 & 358 & 5.0 & good/fair \\
\hline 71 & $\begin{array}{l}\text { Roubidoux Creek } \\
\text { tributary }\end{array}$ & unnamed & $\mathrm{lb}$ & 27.195 & & see $3 a$ & -- & -- & -- \\
\hline 72 & $\begin{array}{l}\text { Roubidoux Creek } \\
\text { tributary }\end{array}$ & unnamed & lb & 27.377 & $12-12-94$ & 0 & -- & - & -- \\
\hline 73 & $\begin{array}{l}\text { Roubidoux Creek } \\
\text { tributary }\end{array}$ & unnamed & $\mathrm{rb}$ & 27.546 & $12-12-94$ & $.03 \mathrm{e}$ & -- & - & -- \\
\hline 74 & Roubidoux Creek & N/A & & 27.657 & $12-12-94$ & 49.1 & 365 & 4.4 & good \\
\hline 75 & Roubidoux Creek & N/A & & 27.980 & $12-12-94$ & 47.7 & 360 & 6.0 & poor \\
\hline 76 & $\begin{array}{l}\text { Roubidoux Creek } \\
\text { tributary }\end{array}$ & unnamed & rb & 28.000 & $12-12-94$ & $.15 \mathrm{e}$ & -- & - & - \\
\hline 77 & Roubidoux Creek & N/A & & 28.458 & $12-12-94$ & 43.4 & 265 & 6.0 & -- \\
\hline 78 & Roubidoux Creek & N/A & & 28.963 & $12-12-94$ & 48.9 & 140 & 5.0 & -- \\
\hline 79 & $\begin{array}{l}\text { Roubidoux Creek } \\
\text { tributary }\end{array}$ & Musgrave Hollow & rb & 29.355 & & see $12 a$ & -- & -- & -- \\
\hline 80 & Roubidoux Creek & N/A & & 29.478 & $12-12-94$ & 41.0 & 318 & 4.8 & fair \\
\hline 81 & Roubidoux Creek & N/A & & 29.724 & $12-12-94$ & 57.4 & 338 & 5.0 & poor \\
\hline 82 & Roubidoux Creek & N/A & & 29.724 & $12-12-94$ & 67.1 & 338 & 5.0 & good \\
\hline 83 & Roubidoux Creek & N/A & & 30.320 & $12-12-94$ & 53.0 & 330 & 5.1 & good \\
\hline 84 & Roubidoux Creek & N/A & & 30.775 & $12-12-94$ & 56.9 & 248 & 5.7 & - \\
\hline 85 & Roubidoux Creek & N/A & & 31.284 & $12-12-94$ & 46.4 & 358 & 5.9 & - \\
\hline 86 & $\begin{array}{l}\text { Roubidoux Creek } \\
\text { tributary }\end{array}$ & unnamed & $\mathrm{rb}$ & 31.296 & $12-12-94$ & .54 & 316 & 6.0 & fair \\
\hline 87 & Roubidoux Creek & N/A & & 32.043 & $12-15-94$ & 39.5 & -- & -- & good \\
\hline 88 & Roubidoux Creek & N/A & & 32.043 & $12-12-94$ & 48.6 & 358 & 7.4 & - \\
\hline 89 & Roubidoux Creek & N/A & & 32.043 & $12-12-94$ & 40.8 & -- & -- & -- \\
\hline 90 & $\begin{array}{l}\text { Roubidoux Creek } \\
\text { tributary }\end{array}$ & unnamed & $\mathrm{lb}$ & 32.056 & $12-12-94$ & 0 & - & -- & -- \\
\hline 91 & $\begin{array}{l}\text { Roubidoux Creek } \\
\text { tributary }\end{array}$ & unnamed & $\mathrm{rb}$ & 32.432 & $12-12-94$ & 0 & -- & -- & -- \\
\hline 92 & $\begin{array}{l}\text { Roubidoux Creek } \\
\text { tributary }\end{array}$ & Little Piney Creek & $\mathrm{rb}$ & 32.823 & $12-12-94$ & $.02 \mathrm{e}$ & 361 & 6.2 & -- \\
\hline 93 & $\begin{array}{l}\text { Roubidoux Creek } \\
\text { tributary }\end{array}$ & unnamed & $1 b$ & 32.969 & $12-12-94$ & $<.01 \mathrm{e}$ & 475 & 6.1 & -- \\
\hline 94 & Roubidoux Creek & N/A & & 33.175 & $12-15-94$ & 35.7 & -- & -- & good \\
\hline 95 & Roubidoux Creek & N/A & & 33.175 & $12-12-94$ & 35.2 & 369 & 4.3 & poor \\
\hline 96 & $\begin{array}{l}\text { Roubidoux Creek } \\
\text { tributary }\end{array}$ & unnamed & $\mathrm{lb}$ & 33.315 & & see $25 a$ & -- & -- & -- \\
\hline 97 & $\begin{array}{l}\text { Roubidoux Creek } \\
\text { tributary }\end{array}$ & unnamed & $\mathrm{lb}$ & 33.548 & $12-12-94$ & 0 & - & -- & -- \\
\hline 98 & Roubidoux Creek & N/A & & 33.849 & $12-15-94$ & 36.6 & -- & -- & good \\
\hline 99 & Roubidoux Creek & N/A & & 33.849 & $12-12-94$ & 44.8 & 363 & 4.1 & good \\
\hline 100 & Highway 17 bridge & N/A & & 33.939 & & - & -- & -- & -- \\
\hline $1 \mathrm{a}$ & Ballard Hollow & N/A & & .117 & $12-13-94$ & $.05 \mathrm{e}$ & 444 & 4.1 & -- \\
\hline $2 a$ & Ballard Hollow & $\mathrm{N} / \mathrm{A}$ & & .907 & $12-13-94$ & $.02 \mathrm{e}$ & -- & - & -- \\
\hline $3 a$ & unnamed stream & $\mathrm{N} / \mathrm{A}$ & & .069 & $12-12-94$ & .37 & 333 & 4.6 & good/fair \\
\hline $4 a$ & unnamed stream & N/A & & .180 & $12-15-94$ & .74 & -- & -- & -- \\
\hline
\end{tabular}


Table 16. Discharge measurements and selected physical properties for the Big Piney River, Roubidoux Creek, and tributaries, December 1994-Continued

\begin{tabular}{|c|c|c|c|c|c|c|c|c|c|}
\hline $\begin{array}{c}\text { Measure- } \\
\text { ment } \\
\text { number }\end{array}$ & Stream name & Tributary name & Bank & $\begin{array}{c}\text { Dlstance } \\
\text { from } \\
\text { mouth } \\
\text { (ml) }\end{array}$ & $\begin{array}{c}\text { Date } \\
\text { (month- } \\
\text { day- } \\
\text { year) }\end{array}$ & $\begin{array}{l}\text { Flow } \\
\text { rate } \\
\left(\mathrm{ft}^{3} / \mathrm{s}\right)\end{array}$ & $\begin{array}{c}\text { Speclfic } \\
\text { conduct- } \\
\text { ance } \\
(\mu \mathrm{S} / \mathrm{cm})\end{array}$ & $\begin{array}{l}\text { Temp. } \\
\left({ }^{\circ} \mathrm{C}\right)\end{array}$ & $\begin{array}{c}\text { Remark or } \\
\text { measure- } \\
\text { ment } \\
\text { rating }\end{array}$ \\
\hline $5 a$ & $\begin{array}{l}\text { unnamed stream } \\
\text { tributary }\end{array}$ & unnamed & $\mathrm{lb}$ & 0.210 & $12-15-94$ & 0 & -- & -- & $\overline{--}$ \\
\hline $6 a$ & $\begin{array}{l}\text { unnamed stream } \\
\text { tributary }\end{array}$ & unnamed & $\mathrm{lb}$ & .911 & $12-15-94$ & 0 & -- & -- & -- \\
\hline $7 \mathrm{a}$ & unnamed stream & N/A & & 1.121 & $12-15-94$ & .19 & 258 & 9.6 & -- \\
\hline $8 a$ & $\begin{array}{l}\text { unnamed stream } \\
\text { tributary }\end{array}$ & Mush Paddle Hollow & $\mathrm{lb}$ & 1.634 & $12-15-94$ & 0 & -- & -- & -- \\
\hline $9 a$ & unnamed stream & N/A & & 1.663 & $12-15-94$ & .24 & 244 & 10.4 & -- \\
\hline $10 \mathrm{a}$ & unnamed stream & N/A & & 2.286 & $12-15-94$ & $.12 \mathrm{e}$ & -- & -- & flow begins \\
\hline $11 \mathrm{a}$ & unnamed stream & N/A & & 2.472 & $12-15-94$ & 0 & -- & -- & -- \\
\hline $12 a$ & Musgrave Hollow & N/A & & .066 & $12-14-94$ & .63 & 336 & 5.3 & fair/poor \\
\hline $13 a$ & Musgrave Hollow & N/A & & .605 & $12-14-94$ & 1.16 & 215 & 4.6 & poor \\
\hline $14 a$ & Musgrave Hollow & N/A & & 1.098 & $12-14-94$ & .88 & 363 & 5.5 & poor \\
\hline $15 a$ & $\begin{array}{l}\text { Musgrave Hollow } \\
\text { tributary }\end{array}$ & unnamed & rb & 1.396 & $12-14-94$ & 0 & -- & -- & -- \\
\hline $16 a$ & Musgrave Hollow & N/A & & 1.642 & $12-14-94$ & .83 & 198 & 4.1 & -- \\
\hline $17 \mathrm{a}$ & Musgrave Hollow & N/A & & 1.642 & $12-14-94$ & .97 & 233 & 4.0 & fair \\
\hline $18 \mathrm{a}$ & $\begin{array}{l}\text { Musgrave Hollow } \\
\text { tributary }\end{array}$ & unnamed & $\mathrm{lb}$ & 1.796 & & see $1 b$ & -- & -- & -- \\
\hline $19 a$ & $\begin{array}{l}\text { Musgrave Hollow } \\
\text { tributary }\end{array}$ & unnamed & $\mathrm{rb}$ & 2.218 & $12-14-94$ & 0 & - & -- & -- \\
\hline $20 \mathrm{a}$ & $\begin{array}{l}\text { Musgrave Hollow } \\
\text { tributary }\end{array}$ & unnamed & $\mathrm{rb}$ & 2.320 & $12-14-94$ & 0 & -- & -- & -- \\
\hline $21 a$ & Musgrave Hollow & N/A & & 2.398 & $12-14-94$ & 1.36 & 234 & 4.1 & fair \\
\hline $22 a$ & Musgrave Hollow & N/A & & 2.878 & $12-14-94$ & .71 & 269 & 5.1 & fair \\
\hline $23 a$ & Musgrave Hollow & N/A & & 3.416 & $12-14-94$ & .50 & 252 & 6.1 & fair \\
\hline $24 a$ & Musgrave Hollow & N/A & & 4.058 & $12-14-94$ & .01 & -- & - & flow begins \\
\hline $25 a$ & unnamed stream & N/A & & .003 & $12-12-94$ & 0 & -- & -- & -- \\
\hline $26 a$ & $\begin{array}{l}\text { unnamed stream } \\
\text { spring }\end{array}$ & N/A & & .085 & $12-12-94$ & $<.01 \mathrm{e}$ & 530 & 10.2 & -- \\
\hline $27 a$ & unnamed stream & N/A & & .152 & $12-12-94$ & 0 & -- & -- & -- \\
\hline $1 b$ & unnamed stream & N/A & & .036 & $12-14-94$ & .57 & 134 & 4.2 & fair \\
\hline $2 b$ & unnamed stream & N/A & & .482 & $12-14-94$ & .25 & 96 & 5.6 & poor \\
\hline $3 b$ & $\begin{array}{l}\text { unnamed stream } \\
\text { spring }\end{array}$ & N/A & & .581 & $12-14-94$ & $.12 \mathrm{e}$ & -- & - & -- \\
\hline $4 b$ & unnamed stream & N/A & & 1.080 & $12-14-94$ & .35 & 343 & 5.7 & fair \\
\hline $5 b$ & unnamed stream & N/A & & 1.378 & $12-14-94$ & 0 & - & -- & -- \\
\hline $6 b$ & unnamed stream & N/A & & 1.920 & $12-14-94$ & 0 & -- & - & - \\
\hline
\end{tabular}


Table 17. Discharge measurements and selected physical properties for the Big Piney River and tributaries, February 1995 [mi, mile; $\mathrm{ft}^{3} / \mathrm{s}$, cubic feet per second; $\mu \mathrm{S} / \mathrm{cm}$, microsiemens per centimeter at 25 degrees Celsius; temp., temperature; ${ }^{\circ} \mathrm{C}$, degrees Celsius; $\mathrm{N} / \mathrm{A}$, not applicable; rb, right bank; --, no data; lb, left bank]

\begin{tabular}{|c|c|c|c|c|c|c|c|c|c|}
\hline $\begin{array}{l}\text { Measurement } \\
\text { number }\end{array}$ & Stream name & Trlbutary name & Bank & $\begin{array}{l}\text { Distance } \\
\text { from } \\
\text { mouth } \\
(\mathrm{ml})\end{array}$ & $\begin{array}{c}\text { Date } \\
\text { (month- } \\
\text { day- } \\
\text { year) }\end{array}$ & $\begin{array}{l}\text { Flow } \\
\text { rate } \\
\left(\mathrm{ft}^{3} / \mathrm{s}\right)\end{array}$ & $\begin{array}{c}\text { Specific } \\
\text { conduct- } \\
\text { ance } \\
(\mu \mathrm{S} / \mathrm{cm})\end{array}$ & $\begin{array}{l}\text { Temp. } \\
\left({ }^{\circ} \mathrm{C}\right)\end{array}$ & $\begin{array}{l}\text { Remark or } \\
\text { measurement } \\
\text { rating }\end{array}$ \\
\hline 1 & Big Piney River & N/A & & 0.462 & $02-22-95$ & 603 & 303 & 9.5 & good \\
\hline 2 & Big Piney tributary & unnamed & $\mathrm{rb}$ & 1.074 & $02-21-95$ & .05 & -- & -. & - \\
\hline 3 & Big Piney tributary & unnamed & $\mathrm{rb}$ & 1.424 & $02-21-95$ & .4 & -- & -- & -- \\
\hline 4 & Big Piney River & N/A & & 1.475 & $02-22-95$ & 601 & 308 & 8.9 & fair/poor \\
\hline 5 & Big Piney tributary & unnamed & $\mathrm{lb}$ & 2.652 & $02-21-95$ & .2 & -- & -- & -- \\
\hline 6 & Big Piney River & N/A & & 3.261 & $02-22-95$ & 591 & 306 & 8.4 & good \\
\hline 7 & Big Piney River & N/A & & 3.261 & $02-21-95$ & 587 & 307 & 8.7 & good \\
\hline 8 & Big Piney tributary & unnamed & $\mathrm{rb}$ & 4.049 & $02-21-95$ & .6 & -- & -- & -- \\
\hline 9 & Big Piney River & N/A & & 4.590 & $02-21-95$ & 622 & 308 & 8.6 & good \\
\hline 10 & Big Piney tributary & unnamed & rb & 5.085 & $02-21-95$ & .03 & -- & -- & -- \\
\hline 11 & Big Piney tributary & unnamed & $\mathrm{lb}$ & 5.589 & $02-21-95$ & 0 & -- & -- & -- \\
\hline 12 & Big Piney tributary & Shanghai Spring & $\mathrm{lb}$ & 5.948 & $02-21-95$ & 25.6 & 389 & 13.3 & good/fair \\
\hline 13 & Big Piney River & N/A & & 6.083 & $02-21-95$ & 566 & 306 & 7.8 & fair \\
\hline 14 & Big Piney River & N/A & & 6.083 & $02-21-95$ & 584 & 306 & 7.8 & fair \\
\hline 15 & Big Piney tributary & unnamed & $\mathrm{lb}$ & 6.235 & $02-21-95$ & .2 & -- & -- & -- \\
\hline 16 & Big Piney River & N/A & & 6.453 & $02-21-95$ & 583 & 307 & 7.4 & fair/poor \\
\hline 17 & Big Piney tributary & unnamed & $\mathrm{lb}$ & 6.470 & $02-21-95$ & 0 & -- & -- & -- \\
\hline 18 & Big Piney tributary & unnamed & $\mathrm{lb}$ & 6.690 & $02-21-95$ & 0 & -- & -- & -- \\
\hline 19 & Big Piney tributary & unnamed & $\mathrm{rb}$ & 7.021 & $02-21-95$ & 0 & -- & -- & -- \\
\hline 20 & Big Piney tributary & unnamed & $\mathrm{lb}$ & 8.155 & $02-21-95$ & 0 & -- & -- & -- \\
\hline 21 & Big Piney tributary & unnamed & $\mathrm{rb}$ & 8.478 & $02-21-95$ & .2 & -- & -- & -- \\
\hline 22 & Big Piney River & N/A & & 8.523 & $02-21-95$ & 598 & 308 & 7.1 & good \\
\hline 23 & Big Piney River & N/A & & 8.523 & $02-20-95$ & 602 & 299 & 9.6 & good/fair \\
\hline 24 & Big Piney tributary & unnamed & $\mathrm{rb}$ & 9.472 & $02-20-95$ & .1 & -- & -- & -- \\
\hline 25 & Big Piney tributary & unnamed & $\mathrm{lb}$ & 10.127 & $02-20-95$ & .02 & -- & -- & -- \\
\hline 26 & Big Piney tributary & unnamed & $\mathrm{lb}$ & 10.764 & $02-20-95$ & 0 & -- & -- & -- \\
\hline 27 & Big Piney tributary & unnamed & $\mathrm{rb}$ & 10.924 & $02-20-95$ & 0 & -- & -- & -- \\
\hline 28 & Big Piney River & N/A & & 10.979 & $02-20-95$ & 611 & 299 & 9.6 & good/fair \\
\hline 29 & Big Piney tributary & unnamed & $\mathrm{lb}$ & 11.104 & $02-20-95$ & 0 & -- & -- & - \\
\hline 30 & Big Piney River & N/A & & 13.319 & $02-20-95$ & 611 & 302 & 9.0 & good \\
\hline 31 & Big Piney tributary & Ousley Spring & $\mathrm{rb}$ & 14.052 & $02-20-95$ & 1.2 & 440 & 13.1 & fair/poor \\
\hline 32 & Big Piney tributary & unnamed & $\mathrm{rb}$ & 14.124 & $02-20-95$ & 1.6 & 385 & 3.8 & good/fair \\
\hline 33 & Big Piney River & N/A & & 14.847 & $02-20-95$ & 601 & 303 & 8.3 & good \\
\hline 34 & Big Piney River & N/A & & 14.847 & $02-20-95$ & 610 & 303 & 8.3 & good \\
\hline 35 & Big Piney tributary & unnamed & $\mathrm{rb}$ & 16.208 & $02-20-95$ & 0 & -- & -- & -- \\
\hline 36 & Big Piney tributary & unnamed & rb & 16.368 & $02-20-95$ & 0 & -- & -- & -- \\
\hline 37 & Big Piney River & N/A & & 16.491 & $02-20-95$ & 615 & 306 & 6.9 & good/fair \\
\hline 38 & Big Piney River & N/A & & 16.491 & $02-17-95$ & 644 & 285 & 7.1 & good \\
\hline 39 & Big Piney tributary & unnamed & $\mathrm{rb}$ & 16.703 & $02-17-95$ & .02 & -- & -- & -- \\
\hline 40 & Big Piney tributary & Spring Creek & $\mathrm{rb}$ & 16.817 & $02-17-95$ & 46.0 & 275 & 10.4 & good/fair \\
\hline 41 & Big Piney River & N/A & & 17.194 & $02-17-95$ & 611 & 288 & 6.5 & good \\
\hline 42 & Big Piney tributary & unnamed & $\mathrm{lb}$ & 17.844 & $02-17-95$ & .1 & -- & -- & -- \\
\hline 43 & Big Piney tributary & unnamed & $\mathrm{lb}$ & 18.798 & $02-17-95$ & .1 & -- & -- & -- \\
\hline 44 & Big Piney River & N/A & & 19.541 & $02-17-95$ & 628 & 285 & 6.5 & good/fair \\
\hline 45 & Big Piney tributary & Stone Mill Spring & $\mathrm{rb}$ & 21.378 & $02-17-95$ & 54.7 & 250 & 12.2 & good \\
\hline 46 & Big Piney tributary & unnamed & $\mathrm{lb}$ & 21.528 & $02-17-95$ & .05 & -- & -- & - \\
\hline
\end{tabular}


Table 17. Discharge measurements and selected physical properties for the Big Piney River and tributaries, February 1995-Continued

\begin{tabular}{|c|c|c|c|c|c|c|c|c|c|}
\hline $\begin{array}{l}\text { Measurement } \\
\text { number }\end{array}$ & Stream name & Tributary name & Bank & $\begin{array}{l}\text { Distance } \\
\text { from } \\
\text { mouth } \\
\text { (mi) }\end{array}$ & $\begin{array}{c}\text { Date } \\
\text { (month- } \\
\text { day- } \\
\text { year) }\end{array}$ & $\begin{array}{c}\text { Flow } \\
\text { rate } \\
\left(\mathrm{ft}^{3} / \mathrm{s}\right)\end{array}$ & $\begin{array}{c}\text { Speciflc } \\
\text { conduct- } \\
\text { ance } \\
(\mu \mathrm{S} / \mathrm{cm})\end{array}$ & $\begin{array}{c}\text { Temp. } \\
\left({ }^{\circ} \mathrm{C}\right)\end{array}$ & $\begin{array}{l}\text { Remark or } \\
\text { measurement } \\
\text { rating }\end{array}$ \\
\hline 47 & Big Piney River & N/A & & 21.999 & $02-17-95$ & 520 & 296 & 4.5 & good \\
\hline 48 & Big Piney River & N/A & & 23.680 & $02-17-95$ & 501 & 295 & 4.7 & fair \\
\hline 49 & Big Piney River & N/A & & 23.680 & $02-14-95$ & 408 & 296 & 4.4 & fair \\
\hline 50 & Big Piney tributary & unnamed & $\mathrm{lb}$ & 24.412 & $02-14-95$ & .05 & -- & -- & -- \\
\hline 51 & Big Piney River & N/A & & 27.219 & $02-14-95$ & 405 & 295 & 4.7 & good \\
\hline 52 & Big Piney River & N/A & & 27.219 & $02-14-95$ & 416 & 295 & 4.7 & good \\
\hline 53 & Big Piney tributary & Miller Spring & $\mathrm{lb}$ & 28.598 & $02-14-95$ & 28.7 & 240 & 12.3 & fair \\
\hline 54 & Big Piney tributary & unnamed & $\mathrm{rb}$ & 29.389 & $02-14-95$ & .1 & -- & -- & -. \\
\hline 55 & Big Piney tributary & unnamed & $\mathrm{rb}$ & 29.874 & $02-14-95$ & 0 & -- & -- & -- \\
\hline 56 & Big Piney tributary & unnamed & $\mathrm{rb}$ & 30.013 & $02-14-95$ & 2.0 & -- & -- & -- \\
\hline 57 & Big Piney tributary & unnamed & $\mathrm{rb}$ & 30.064 & $02-14-95$ & 0 & -- & -- & -- \\
\hline 58 & Big Piney River & N/A & & 30.156 & $02-14-95$ & 379 & 294 & 4.6 & good \\
\hline 59 & Big Piney tributary & unnamed & $\mathrm{rb}$ & 31.138 & $02-14-95$ & 0 & -- & -- & -- \\
\hline 60 & Big Piney tributary & unnamed & $\mathrm{lb}$ & 31.228 & $02-14-95$ & 0 & -- & -- & -- \\
\hline 61 & Big Piney River & $\mathrm{N} / \mathrm{A}$ & & 32.166 & $02-14-95$ & 388 & 298 & 4.2 & good \\
\hline 62 & Big Piney River & N/A & & 32.166 & $02-13-95$ & 386 & 289 & 5.4 & good \\
\hline 63 & Big Piney River & N/A & & 33.524 & $02-13-95$ & 397 & 290 & 5.4 & good \\
\hline 64 & Big Piney tributary & Bald Ridge Creek & $\mathrm{lb}$ & 33.876 & $02-13-95$ & 3.7 & 275 & 4.4 & fair \\
\hline 65 & Big Piney tributary & unnamed & $\mathrm{rb}$ & 34.373 & $02-13-95$ & 0 & -- & -- & -- \\
\hline 66 & Big Piney River & N/A & & 34.658 & $02-13-95$ & 374 & 292 & 5.2 & good \\
\hline 67 & Big Piney River & N/A & & 34.658 & $02-13-95$ & 397 & 292 & 5.2 & good \\
\hline 68 & Big Piney tributary & unnamed & $\mathrm{lb}$ & 34.812 & $02-13-95$ & .2 & -- & -- & -- \\
\hline 69 & Big Piney tributary & unnamed & $\mathrm{lb}$ & 35.822 & $02-13-95$ & .2 & -- & -- & -- \\
\hline 70 & Big Piney Tributary & unnamed & $\mathrm{lb}$ & 35.870 & $02-13-95$ & .2 & -- & -- & -- \\
\hline 71 & Big Piney River & N/A & & 36.403 & $02-13-95$ & 396 & 292 & 4.8 & good \\
\hline 72 & Big Piney River & N/A & & 37.897 & $02-13-95$ & 382 & 292 & 4.0 & good \\
\hline
\end{tabular}


Table 18. Discharge measurements and selected physical properties for the Big Piney River, Roubidoux Creek, and tributaries, September 1995

[mi, mile; $\mathrm{ft}^{3} / \mathrm{s}$, cubic feet per second; spec. cond., specific conductance; $\mu \mathrm{S} / \mathrm{cm}$, microsiemens per centimeter at 25 degrees Celsius; temp., temperature; ${ }^{\circ} \mathrm{C}$, degrees Celsius; N/A, not applicable; rb, right bank; --, no data; lb, left bank; e, estimated; see la, see measurement no. la]

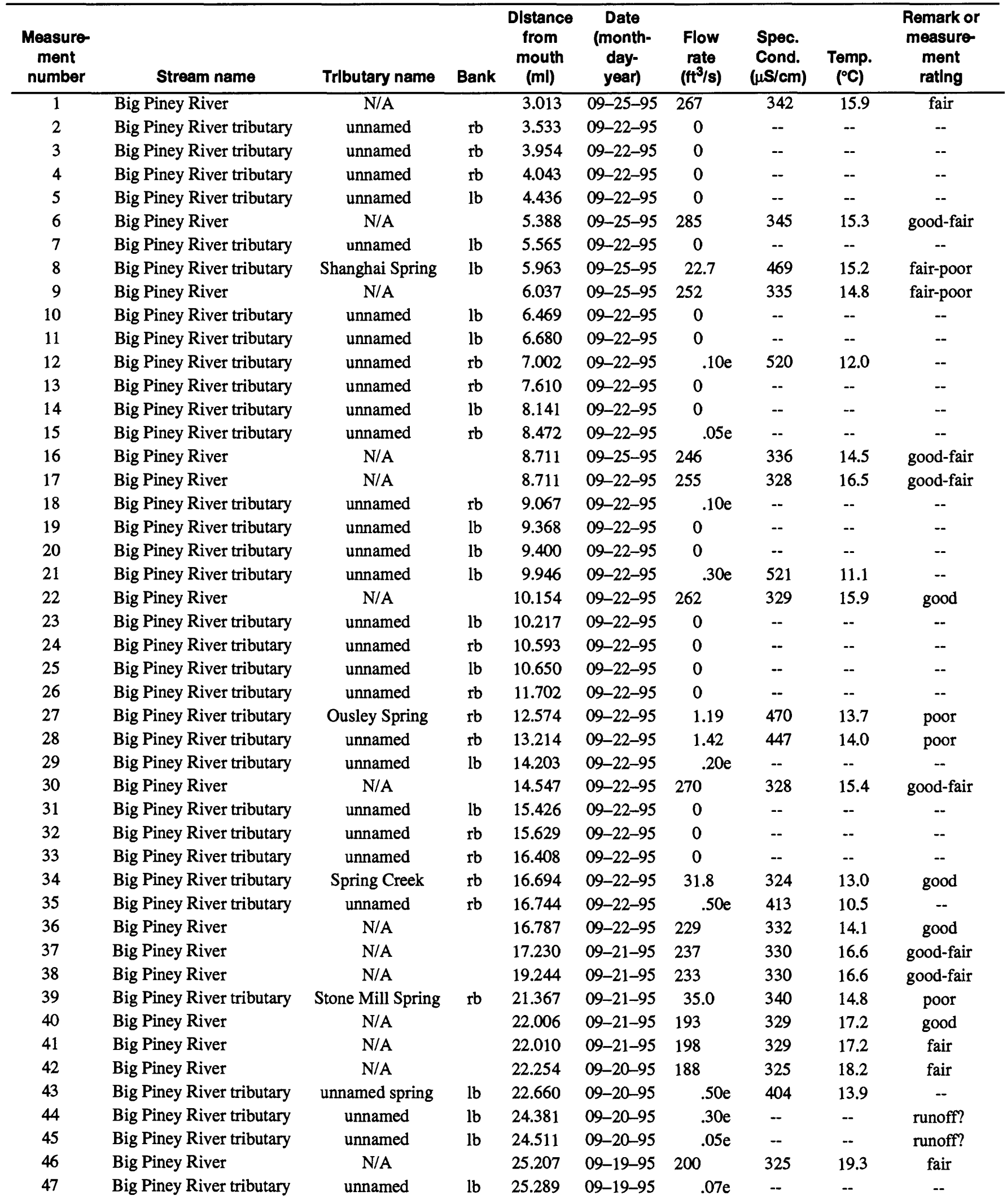


Table 18. Discharge measurements and selected physical properties for the Big Piney River, Roubidoux Creek, and tributaries, September 1995-Continued

\begin{tabular}{|c|c|c|c|c|c|c|c|c|c|}
\hline $\begin{array}{c}\text { Measure- } \\
\text { ment } \\
\text { number }\end{array}$ & Stream name & Trlbutary name & Bank & $\begin{array}{l}\text { Dlstance } \\
\text { from } \\
\text { mouth } \\
\text { (ml) }\end{array}$ & $\begin{array}{c}\text { Date } \\
\text { (month- } \\
\text { day- } \\
\text { year) }\end{array}$ & $\begin{array}{c}\text { Flow } \\
\text { rate } \\
\left(\mathrm{ft}^{3} / \mathrm{s}\right)\end{array}$ & $\begin{array}{l}\text { Spec. } \\
\text { Cond. } \\
(\mu \mathrm{S} / \mathrm{cm})\end{array}$ & $\begin{array}{c}\text { Temp. } \\
\left({ }^{\circ} \mathrm{C}\right)\end{array}$ & $\begin{array}{l}\text { Remark or } \\
\text { measure- } \\
\text { ment } \\
\text { rating }\end{array}$ \\
\hline 48 & Big Piney River & N/A & & 25.855 & $09-20-95$ & 195 & 325 & 18.1 & good-fair \\
\hline 49 & Big Piney River tributary & unnamed & $\mathrm{rb}$ & 26.940 & $09-19-95$ & 0 & -- & -- & -- \\
\hline 50 & Big Piney River & N/A & & 27.051 & $09-20-95$ & 189 & 329 & 17.6 & good-fair \\
\hline 51 & Big Piney River & N/A & & 27.583 & 09-19-95 & 194 & 328 & 19.1 & fair \\
\hline 52 & Big Piney River tributary & unnamed & rb & 28.135 & $09-20-95$ & 0 & - & -- & -- \\
\hline 53 & Big Piney River tributary & Miller Spring & $\mathrm{lb}$ & 28.581 & $09-20-95$ & 7.31 & 370 & 13.8 & fair \\
\hline 54 & Big Piney River tributary & Miller Spring & $\mathrm{lb}$ & 28.581 & 09-19-95 & 14.2 & 369 & 13.8 & poor \\
\hline 55 & Big Piney River tributary & unnamed & lb & 28.715 & 09-19-95 & 0 & -- & -- & - \\
\hline 56 & Big Piney River tributary & unnamed & rb & 29.344 & 09-19-95 & 0 & -- & -- & -- \\
\hline 57 & Big Piney River tributary & unnamed & lb & 29.508 & 09-19-95 & 0 & -- & -- & -- \\
\hline 58 & Big Piney River tributary & unnamed & lb & 29.876 & 09-19-95 & 0 & -- & -- & - \\
\hline 59 & Big Piney River tributary & unnamed spring & rb & 29.947 & 09-19-95 & $.15 \mathrm{e}$ & 478 & 14.4 & -- \\
\hline 60 & Big Piney River tributary & unnamed slough & $\mathrm{rb}$ & 29.986 & 09-19-95 & $.05 \mathrm{e}$ & -- & -- & - \\
\hline 61 & Big Piney River & N/A & & 30.024 & 09-20-95 & 180 & 328 & 17.9 & good \\
\hline 62 & Big Piney River & N/A & & 30.024 & 09-19-95 & 168 & 327 & 19.3 & good \\
\hline 63 & Big Piney River tributary & unnamed & rb & 30.729 & 09-19-95 & 0 & -- & -- & -- \\
\hline 64 & Big Piney River tributary & unnamed spring & lb & 30.967 & 09-19-95 & $.20 \mathrm{e}$ & 380 & 13.9 & -- \\
\hline 65 & Big Piney River tributary & unnamed & $\mathrm{rb}$ & 31.113 & 09-19-95 & 0 & -- & -- & -- \\
\hline 66 & Big Piney River tributary & unnamed & lb & 31.154 & 09-18-95 & 0 & -- & -- & -- \\
\hline 67 & Big Piney River tributary & unnamed & $\mathrm{rb}$ & 31.527 & 09-19-95 & 0 & -- & -- & - \\
\hline 68 & Big Piney River tributary & unnamed & $\mathrm{rb}$ & 31.835 & 09-19-95 & 0 & -- & -- & -- \\
\hline 69 & Big Piney River & N/A & & 32.120 & 09-19-95 & 177 & 329 & 19.1 & good \\
\hline 70 & Big Piney River & N/A & & 32.120 & 09-18-95 & 174 & -- & -- & good-fair \\
\hline 71 & Big Piney River tributary & unnamed & $\mathrm{rb}$ & 32.384 & 09-18-95 & 0 & -- & -- & -- \\
\hline 72 & Big Piney River tributary & unnamed & rb & 32.714 & $09-18-95$ & 0 & -- & -- & -- \\
\hline 73 & Big Piney River tributary & unnamed & lb & 33.393 & 09-18-95 & 0 & -- & -- & -- \\
\hline 74 & Big Piney River tributary & unnamed & lb & 33.784 & $09-18-95$ & $.15 \mathrm{e}$ & -- & -- & -- \\
\hline 75 & Big Piney River tributary & Bald Ridge Creek & lb & 33.826 & $09-18-95$ & $.50 \mathrm{e}$ & -- & -- & -- \\
\hline 76 & Big Piney River & N/A & & 34.024 & $09-18-95$ & 173 & -- & -- & good-fair \\
\hline 77 & Big Piney River & N/A & & 34.024 & 09-18-95 & 174 & -- & -- & good \\
\hline 78 & Big Piney River tributary & unnamed & $\mathrm{rb}$ & 34.321 & $09-18-95$ & 0 & -- & -- & -- \\
\hline 79 & Big Piney River tributary & unnamed & lb & 34.759 & 09-18-95 & 0 & -- & -- & -- \\
\hline 80 & Big Piney River tributary & unnamed & lb & 35.342 & 09-18-95 & 0 & -- & -- & -- \\
\hline 81 & Big Piney River & N/A & & 35.965 & 09-18-95 & 190 & 328 & 19.0 & good-fair \\
\hline 82 & Big Piney River tributary & unnamed & lb & 36.129 & $09-18-95$ & .05 & 413 & 14.6 & -- \\
\hline 83 & Big Piney River tributary & unnamed & lb & 36.408 & 09-18-95 & .10 & 419 & 14.7 & - \\
\hline 84 & Big Piney River tributary & Crossing Hollow & rb & 36.453 & $09-18-95$ & .07 & 462 & 14.4 & -- \\
\hline 85 & Big Piney River & N/A & & 37.841 & 09-18-95 & 182 & 324 & 18.4 & good-fair \\
\hline 1 & Roubidoux Creek & N/A & & .403 & $09-06-95$ & 23.7 & 400 & 21.1 & good \\
\hline 2 & Roubidoux Creek & N/A & & 1.490 & $09-06-95$ & 23.6 & 405 & 19.3 & fair-poor \\
\hline 3 & Roubidoux Creek tributary & unnamed & rb & 1.621 & $09-05-95$ & 0 & -- & -- & -- \\
\hline 4 & Roubidoux Creek tributary & STP outflow & & 1.725 & $09-06-95$ & .43 & 392 & 17.6 & poor \\
\hline 5 & Roubidoux Creek tributary & unnamed spring & lb & 2.312 & $09-05-95$ & 1.05 & 393 & 17.5 & good-fair \\
\hline 6 & Roubidoux Creek tributary & unnamed & lb & 2.568 & $09-05-95$ & 0 & -- & -- & -- \\
\hline 7 & Roubidoux Creek tributary & unnamed & $\mathrm{lb}$ & 2.626 & $09-05-95$ & 0 & -- & -- & -- \\
\hline 8 & Roubidoux Creek & N/A & & 2.787 & $09-06-95$ & 22.7 & 352 & 17.7 & good \\
\hline 9 & Roubidoux Creek & N/A & & 2.787 & $09-05-95$ & 22.5 & 388 & 17.9 & fair \\
\hline 10 & Roubidoux Creek & N/A & & 3.072 & $09-05-95$ & .73 & 380 & 29.2 & fair-poor \\
\hline 11 & Roubidoux Creek & N/A & & 3.567 & $09-05-95$ & .92 & -- & -- & fair \\
\hline
\end{tabular}


Table 18. Discharge measurements and selected physical properties for the Big Piney River, Roubidoux Creek, and tributaries, September 1995-Continued

\begin{tabular}{|c|c|c|c|c|c|c|c|c|c|}
\hline $\begin{array}{c}\text { Measure- } \\
\text { ment } \\
\text { number }\end{array}$ & Stream name & Trlbutary name & Bank & $\begin{array}{c}\text { Distance } \\
\text { from } \\
\text { mouth } \\
\text { (ml) }\end{array}$ & $\begin{array}{c}\text { Date } \\
\text { (month- } \\
\text { day- } \\
\text { year) }\end{array}$ & $\begin{array}{c}\text { Flow } \\
\text { rate } \\
\left(\mathrm{ft}^{3} / \mathrm{s}\right)\end{array}$ & $\begin{array}{l}\text { Spec. } \\
\text { Cond. } \\
(\mu S / c m)\end{array}$ & $\begin{array}{c}\text { Temp. } \\
\left({ }^{\circ} \mathrm{C}\right)\end{array}$ & $\begin{array}{c}\text { Remark or } \\
\text { measure- } \\
\text { ment } \\
\text { rating }\end{array}$ \\
\hline 12 & Roubidoux Creek tributary & unnamed & $\overline{\mathrm{rb}}$ & 4.585 & $09-05-95$ & 0 & -- & -- & -- \\
\hline 13 & Roubidoux Creek & N/A & & 4.716 & $09-05-95$ & .52 & & & \\
\hline 14 & Roubidoux Creek tributary & unnamed & $\mathrm{rb}$ & 4.848 & $09-05-95$ & 0 & -- & -- & -- \\
\hline 15 & Roubidoux Creek & N/A & & 5.555 & $09-05-95$ & .20 & -- & -- & -- \\
\hline 16 & Roubidoux Creek & N/A & & 6.059 & $09-05-95$ & .03 & -- & -- & -- \\
\hline 17 & Roubidoux Creek & N/A & & 6.991 & $09-05-95$ & 0 & -- & -- & -- \\
\hline 18 & Roubidoux Creek tributary & unnamed spring & rb & 7.148 & $09-05-95$ & .08 & -- & -- & -- \\
\hline 19 & Roubidoux Creek tributary & $\begin{array}{l}\text { Tunnel Hollow } \\
\text { stream }\end{array}$ & rb & 7.287 & $09-05-95$ & 0 & -- & -- & -- \\
\hline 20 & Roubidoux Creek & N/A & & 7.473 & $09-05-95$ & $.01 \mathrm{e}$ & -- & -- & -- \\
\hline 21 & Roubidoux Creek & N/A & & 8.234 & 09-05-95 & .10 & 401 & 26.9 & good \\
\hline 22 & Roubidoux Creek tributary & $\begin{array}{c}\text { Ballard Hollow } \\
\text { stream }\end{array}$ & rb & 8.295 & 09-05-95 & .18 & 463 & 22.2 & fair \\
\hline 23 & Roubidoux Creek & N/A & & 8.340 & $09-05-95$ & 0 & -- & -- & flow begins \\
\hline 24 & Roubidoux Creek tributary & unnamed & lb & 24.034 & $09-12-95$ & 0 & -- & -- & - \\
\hline 25 & Roubidoux Creek & N/A & & 24.062 & 09-13-95 & 0 & -- & -- & end of flow \\
\hline 26 & Roubidoux Creek & N/A & & 24.343 & $09-13-95$ & 2.01 & 349 & 22.5 & good-fair \\
\hline 27 & Roubidoux Creek & N/A & & 25.039 & $09-13-95$ & 7.03 & 354 & 22.2 & good-fair \\
\hline 28 & Roubidoux Creek & N/A & & 25.801 & 09-13-95 & 8.38 & 351 & 22.8 & good \\
\hline 29 & Roubidoux Creek & N/A & & 25.801 & $09-12-95$ & 8.52 & 328 & 22.7 & good \\
\hline 30 & Roubidoux Creek tributary & unnamed & rb & 26.192 & $09-12-95$ & 0 & -- & -- & -- \\
\hline 31 & Roubidoux Creek & N/A & & 26.823 & $09-12-95$ & 8.17 & 353 & 22.4 & fair \\
\hline 32 & Roubidoux Creek tributary & unnamed & rb & 26.902 & $09-12-95$ & 0 & -- & -- & -- \\
\hline 33 & Roubidoux Creek tributary & unnamed & lb & 27.155 & $09-12-95$ & 0 & -- & -- & -- \\
\hline 34 & Roubidoux Creek tributary & unnamed & $\mathrm{lb}$ & 27.347 & $09-12-95$ & 0 & -- & -- & -- \\
\hline 35 & Roubidoux Creek tributary & unnamed & rb & 27.504 & $09-12-95$ & $.03 e$ & -- & -- & -- \\
\hline 36 & Roubidoux Creek tributary & unnamed & rb & 28.005 & $09-12-95$ & $.05 \mathrm{e}$ & -- & -- & -- \\
\hline 37 & Roubidoux Creek & N/A & & 28.054 & 09-12-95 & 9.32 & 358 & 21.3 & good-fair \\
\hline 38 & Roubidoux Creek & N/A & & 28.064 & $09-11-95$ & 9.62 & 354 & · $\quad 20.4$ & good-fair \\
\hline 39 & Roubidoux Creek & N/A & & 28.963 & $09-11-95$ & 9.73 & 355 & 21.5 & good \\
\hline 40 & Roubidoux Creek tributary & unnamed & $\mathrm{lb}$ & 29.155 & $09-12-95$ & 0 & -- & -- & -- \\
\hline 41 & Roubidoux Creek tributary & Musgrave Hollow & & 29.303 & & see $1 \mathrm{a}$ & -- & -- & -- \\
\hline 42 & Roubidoux Creek & N/A & & 29.638 & $09-11-95$ & 6.67 & 356 & 21.8 & poor \\
\hline 43 & Roubidoux Creek & N/A & & 29.763 & $09-11-95$ & 7.33 & 356 & 21.7 & good-fair \\
\hline 44 & Roubidoux Creek tributary & unnamed & rb & 30.753 & 09-11-95 & 0 & -- & -- & -- \\
\hline 45 & Roubidoux Creek & N/A & & 31.062 & $09-11-95$ & 8.06 & 350 & 22.2 & fair \\
\hline 46 & Roubidoux Creek tributary & unnamed & rb & 31.247 & $09-11-95$ & $.15 \mathrm{e}$ & 343 & 19.7 & -- \\
\hline 47 & Roubidoux Creek & N/A & & 31.909 & $09-11-95$ & 8.12 & 353 & 22.2 & poor \\
\hline 48 & Roubidoux Creek & N/A & & 31.909 & $09-12-95$ & 7.63 & 354 & 20.6 & good \\
\hline 49 & Roubidoux Creek tributary & Little Piney Creeek & rb & 32.767 & $09-12-95$ & $.01 \mathrm{e}$ & 396 & 18.8 & -- \\
\hline 50 & Roubidoux Creek tributary & unnamed & rb & 32.818 & $09-12-95$ & $.01 \mathrm{e}$ & 302 & 21.2 & -- \\
\hline 51 & Roubidoux Creek & N/A & & 32.853 & $09-12-95$ & 6.73 & 358 & 21.5 & fair \\
\hline 52 & Roubidoux Creek tributary & unnamed & $1 b$ & 33.229 & $09-11-95$ & 0 & -- & -- & -- \\
\hline 53 & Roubidoux Creek tributary & unnamed & $1 b$ & 33.433 & $09-11-95$ & 0 & -- & -- & -- \\
\hline 54 & Roubidoux Creek & N/A & & 33.796 & $09-05-95$ & 6.28 & 358 & 22.2 & -- \\
\hline 1a & Musgrave Hollow & N/A & & .000 & $09-12-95$ & 0 & -- & -- & - \\
\hline $2 a$ & Musgrave Hollow tributary & unnamed & rb & 1.376 & & see $1 b$ & -- & -- & -- \\
\hline $3 a$ & Musgrave Hollow & N/A & & 1.541 & $09-12-95$ & $.45 \mathrm{e}$ & -- & -- & -- \\
\hline $1 \mathrm{~b}$ & unnamed tributary & N/A & & .457 & $09-12-95$ & $.05 \mathrm{e}$ & -- & -- & - \\
\hline
\end{tabular}


Table 19. Constituents and detection limits of inorganic and organic analyses for water and sediment samples and Missouri Department of Natural Resources drinking-water maximum contaminant levels (MCL)

[MRL, method reporting level; $\mu \mathrm{S} / \mathrm{cm}$, microsiemens per centimeter at 25 degrees Celsius; --, no data available; mg/L, milligrams per liter; $\mu \mathrm{g} / \mathrm{L}$, micrograms per liter; $\mathrm{L}$, listed; $\mu \mathrm{g} / \mathrm{kg}$, micrograms per kilogram; $\mathrm{ng} / \mathrm{g}$, nanograms per gram; PCN, Polychlorinated nepthalene; EPTC, s-Ethyl dipropylthiocarbamate; BHC, 1,2,3,4,5,6,-Hexachlorocyclohexane; DCPA, N-(3,4-dichlorophenyl)propionamide; ***, not determined]

\begin{tabular}{|c|c|c|c|}
\hline Group or famlly & Constltuent & MRL & MCL \\
\hline \multicolumn{4}{|c|}{ Physical properties and inorganic compounds, in water } \\
\hline & Specific conductance & $1.0 \mu \mathrm{S} / \mathrm{cm}$ & -- \\
\hline & $\mathrm{pH}$ & .01 units & $6.5-9.0$ \\
\hline & Oxygen, dissolved & $.1 \mathrm{mg} / \mathrm{L}$ & -- \\
\hline & Calcium, dissolved & $.02 \mathrm{mg} / \mathrm{L}$ & -- \\
\hline & Calcium, total & $.02 \mathrm{mg} / \mathrm{L}$ & -- \\
\hline & Magnesium, dissolved & $.02 \mathrm{mg} / \mathrm{L}$ & -- \\
\hline & Magnesium, total & $.002 \mathrm{mg} / \mathrm{L}$ & -- \\
\hline & Sodium, dissolved & $.2 \mathrm{mg} / \mathrm{L}$ & -- \\
\hline & Sodium, total & $.5 \mathrm{mg} / \mathrm{L}$ & -- \\
\hline & Potassium, dissolved & $.1 \mathrm{mg} / \mathrm{L}$ & -- \\
\hline & Alkalinity, total, by incremental titration & $1.0 \mathrm{mg} / \mathrm{L}$ & -- \\
\hline & Bicarbonate, by incremental titration & $1.0 \mathrm{mg} / \mathrm{L}$ & -- \\
\hline & Carbonate, by incremental titration & $1.0 \mathrm{mg} / \mathrm{L}$ & -- \\
\hline & Alkalinity, total, $\mathrm{pH} 4.5$ end point & $1.0 \mathrm{mg} / \mathrm{L}$ & -- \\
\hline & Sulfate, dissolved & $.2 \mathrm{mg} / \mathrm{L}$ & $250 \mathrm{mg} / \mathrm{L}$ \\
\hline & Chloride, dissolved & $.1 \mathrm{mg} / \mathrm{L}$ & $250 \mathrm{mg} / \mathrm{L}$ \\
\hline & Fluoride, dissolved & $.01 \mathrm{mg} / \mathrm{L}$ & $4 \mathrm{mg} / \mathrm{L}$ \\
\hline & Silica, dissolved & $.1 \mathrm{mg} / \mathrm{L}$ & - \\
\hline & Cyanide, total & $.01 \mathrm{mg} / \mathrm{L}$ & $.2 \mathrm{mg} / \mathrm{L}$ \\
\hline & Dissolved solids, residue at 180 degrees Celsius & $1.0 \mathrm{mg} / \mathrm{L}$ & -- \\
\hline & Dissolved solids, sum of constituents & $1.0 \mathrm{mg} / \mathrm{L}$ & -- \\
\hline & Hardness, total & $1.0 \mathrm{mg} / \mathrm{L}$ & -- \\
\hline & Organic carbon, total & $.1 \mathrm{mg} / \mathrm{L}$ & -- \\
\hline & Nitrite plus nitrate, total as nitrogen & $.01 \mathrm{mg} / \mathrm{L}$ & -- \\
\hline & Nitrite, total as nitrogen & $.001 \mathrm{mg} / \mathrm{L}$ & -- \\
\hline & Ammonia, total as nitrogen & $.01 \mathrm{mg} / \mathrm{L}$ & -- \\
\hline & Phosphorus, total & $.010 \mathrm{mg} / \mathrm{L}$ & -- \\
\hline & Fecal coliform, in colonies per 100 milliliters & 1 & -- \\
\hline & Fecal streptococci, in colonies per 100 milliliters & 1 & -- \\
\hline & Antimony, total & $1.0 \mu \mathrm{g} / \mathrm{L}$ & $6 \mu \mathrm{g} / \mathrm{L}$ \\
\hline & Arsenic, total & $1.0 \mu \mathrm{g} / \mathrm{L}$ & $50 \mu \mathrm{g} / \mathrm{L}$ \\
\hline & Barium, dissolved & $1.0 \mu \mathrm{g} / \mathrm{L}$ & -- \\
\hline & Barium, total & $5.0 \mu \mathrm{g} / \mathrm{L}$ & $2,000 \mu \mathrm{g} / \mathrm{L}$ \\
\hline & Beryllium, dissolved & $.5 \mu \mathrm{g} / \mathrm{L}$ & -- \\
\hline & Beryllium, total & $1.0 \mu \mathrm{g} / \mathrm{L}$ & $4 \mu \mathrm{g} / \mathrm{L}$ \\
\hline & Boron, dissolved & $10.0 \mu \mathrm{g} / \mathrm{L}$ & -- \\
\hline & Boron, total & $20.0 \mu \mathrm{g} / \mathrm{L}$ & $\mathrm{L}$ \\
\hline & Cadmium, dissolved & $1.0 \mu \mathrm{g} / \mathrm{L}$ & - \\
\hline & Cadmium, total & $5.0 \mu \mathrm{g} / \mathrm{L}$ & $5 \mu \mathrm{g} / \mathrm{L}$ \\
\hline & Chromium, dissolved & $5.0 \mu \mathrm{g} / \mathrm{L}$ & -- \\
\hline & Chromium, total & $10.0 \mu \mathrm{g} / \mathrm{L}$ & $100 \mu \mathrm{g} / \mathrm{L}$ \\
\hline & Cobalt, dissolved & $3.0 \mu \mathrm{g} / \mathrm{L}$ & -- \\
\hline & Cobalt, total & $10.0 \mu \mathrm{g} / \mathrm{L}$ & -- \\
\hline & Copper, dissolved & $10.0 \mu \mathrm{g} / \mathrm{L}$ & -- \\
\hline & Copper, total & $10.0 \mu \mathrm{g} / \mathrm{L}$ & $1,000 \mu \mathrm{g} / \mathrm{L}$ \\
\hline & Iron, dissolved & $3.0 \mu \mathrm{g} / \mathrm{L}$ & -- \\
\hline & Iron, total & $5.0 \mu \mathrm{g} / \mathrm{L}$ & $300 \mu \mathrm{g} / \mathrm{L}$ \\
\hline & Lead, dissolved & $10.0 \mu \mathrm{g} / \mathrm{L}$ & - \\
\hline
\end{tabular}


Table 19. Constituents and detection limits of inorganic and organic analyses for water and sediment samples and Missouri Department of Natural Resources drinking-water maximum contaminant levels (MCL)-Continued

\begin{tabular}{|c|c|c|c|}
\hline Group or famlly & Constltuent & MRL & MCL \\
\hline \multicolumn{4}{|c|}{ Physical properties and inorganic compounds, in water-Continued } \\
\hline & Lead, total & $1.0 \mu \mathrm{g} / \mathrm{L}$ & $15 \mu \mathrm{g} / \mathrm{L}$ \\
\hline & Lithium, dissolved & $4.0 \mu \mathrm{g} / \mathrm{L}$ & -- \\
\hline & Manganese, dissolved & $1.0 \mu \mathrm{g} / \mathrm{L}$ & -- \\
\hline & Manganese, total & $5.0 \mu \mathrm{g} / \mathrm{L}$ & $50 \mu \mathrm{g} / \mathrm{L}$ \\
\hline & Mercury, total & $.10 \mu \mathrm{g} / \mathrm{L}$ & $2 \mu \mathrm{g} / \mathrm{L}$ \\
\hline & Molybdenum, dissolved & $10.0 \mu \mathrm{g} / \mathrm{L}$ & -- \\
\hline & Nickel, dissolved & $10.0 \mu \mathrm{g} / \mathrm{L}$ & -- \\
\hline & Nickel, total & $10.0 \mu \mathrm{g} / \mathrm{L}$ & $100 \mu \mathrm{g} / \mathrm{L}$ \\
\hline & Selenium, total & $1.0 \mu \mathrm{g} / \mathrm{L}$ & $50 \mu \mathrm{g} / \mathrm{L}$ \\
\hline & Silver, dissolved & $1.0 \mu \mathrm{g} / \mathrm{L}$ & -- \\
\hline & Silver, total & $5.0 \mu \mathrm{g} / \mathrm{L}$ & $100 \mu \mathrm{g} / \mathrm{L}$ \\
\hline & Strontium, dissolved & $10.0 \mu \mathrm{g} / \mathrm{L}$ & -- \\
\hline & Thallium, total & $1.0 \mu \mathrm{g} / \mathrm{L}$ & $2 \mu \mathrm{g} / \mathrm{L}$ \\
\hline & Vanadium, dissolved & $6.0 \mu \mathrm{g} / \mathrm{L}$ & -- \\
\hline & Vanadium, total & $10.0 \mu \mathrm{g} / \mathrm{L}$ & $\mathrm{L}$ \\
\hline & Zinc, dissolved & $3.0 \mu \mathrm{g} / \mathrm{L}$ & -- \\
\hline & Zinc total & $5.0 \mu \mathrm{g} / \mathrm{L}$ & $5,000 \mu \mathrm{g} / \mathrm{L}$ \\
\hline \multicolumn{4}{|c|}{ Volatile organic compounds (total), in water } \\
\hline Substituted ethane & Chloroethane & $0.2 \mu \mathrm{g} / \mathrm{L}$ & -- \\
\hline & 1,2-Dibromoethane (EDB) & $.2 \mu \mathrm{g} / \mathrm{L}$ & $0.05 \mu \mathrm{g} / \mathrm{L}$ \\
\hline & 1,1-Dichloroethane & $.2 \mu \mathrm{g} / \mathrm{L}$ & -- \\
\hline & 1,2-Dichloroethane & $.2 \mu \mathrm{g} / \mathrm{L}$ & $5 \mu \mathrm{g} / \mathrm{L}$ \\
\hline & 1,1,1-Trichloroethane & $.2 \mu \mathrm{g} / \mathrm{L}$ & $200 \mu \mathrm{g} / \mathrm{L}$ \\
\hline & 1,1,2-Trichloroethane & $.2 \mu \mathrm{g} / \mathrm{L}$ & $5 \mu \mathrm{g} / \mathrm{L}$ \\
\hline & 1,1,1,2-Tetrachloroethane & $.2 \mu \mathrm{g} / \mathrm{L}$ & -- \\
\hline & 1,1,2,2-Tetrachloroethane & $.2 \mu \mathrm{g} / \mathrm{L}$ & -- \\
\hline & Trichlorotrifluoroethane & $.2 \mu \mathrm{g} / \mathrm{L}$ & -- \\
\hline \multirow[t]{6}{*}{ Substituted ethene } & Vinyl chloride & $.2 \mu \mathrm{g} / \mathrm{L}$ & $2 \mu \mathrm{g} / \mathrm{L}$ \\
\hline & 1,1-Dichloroethene & $.2 \mu \mathrm{g} / \mathrm{L}$ & $7 \mu g / L$ \\
\hline & cis-1,2-Dichloroethene & $.2 \mu \mathrm{g} / \mathrm{L}$ & $70 \mu \mathrm{g} / \mathrm{L}$ \\
\hline & trans-1,2-Dichloroethene & $.2 \mu \mathrm{g} / \mathrm{L}$ & $100 \mu \mathrm{g} / \mathrm{L}$ \\
\hline & 1,1,2-Trichloroethene & $.2 \mu \mathrm{g} / \mathrm{L}$ & $5 \mu \mathrm{g} / \mathrm{L}$ \\
\hline & Tetrachloroethene (PCE) & $.2 \mu \mathrm{g} / \mathrm{L}$ & $5 \mu \mathrm{g} / \mathrm{L}$ \\
\hline \multirow[t]{16}{*}{ Substituted methane } & Bromomethane & $.2 \mu \mathrm{g} / \mathrm{L}$ & -- \\
\hline & Dibromomethane & $.2 \mu \mathrm{g} / \mathrm{L}$ & -- \\
\hline & Bromoform & $.2 \mu \mathrm{g} / \mathrm{L}$ & $100 \mu \mathrm{g} / \mathrm{L}$ \\
\hline & Bromochloromethane & $.2 \mu \mathrm{g} / \mathrm{L}$ & -- \\
\hline & Dibromochloromethane & $.2 \mu \mathrm{g} / \mathrm{L}$ & $100 \mu \mathrm{g} / \mathrm{L}$ \\
\hline & Chloromethane & $.2 \mu \mathrm{g} / \mathrm{L}$ & -- \\
\hline & Dichloromethane & $.2 \mu \mathrm{g} / \mathrm{L}$ & $5 \mu \mathrm{g} / \mathrm{L}$ \\
\hline & Chloroform & $.2 \mu \mathrm{g} / \mathrm{L}$ & $100 \mu \mathrm{g} / \mathrm{L}$ \\
\hline & Chlorofluoromethane & $.2 \mu \mathrm{g} / \mathrm{L}$ & -- \\
\hline & Carbon tetrachloride & $.2 \mu \mathrm{g} / \mathrm{L}$ & $5 \mu \mathrm{g} / \mathrm{L}$ \\
\hline & Dichlorobromomethane & $.2 \mu \mathrm{g} / \mathrm{L}$ & $100 \mu \mathrm{g} / \mathrm{L}$ \\
\hline & Dichlorofluoromethane & $.2 \mu \mathrm{g} / \mathrm{L}$ & -- \\
\hline & Dichlorodifluoromethane & $.2 \mu \mathrm{g} / \mathrm{L}$ & -- \\
\hline & Trichlorofluoromethane & $.2 \mu \mathrm{g} / \mathrm{L}$ & -- \\
\hline & Methyl iodide & $.5 \mu \mathrm{g} / \mathrm{L}$ & -- \\
\hline & Carbon disulfide & $.2 \mu \mathrm{g} / \mathrm{L}$ & -- \\
\hline
\end{tabular}


Table 19. Constituents and detection limits of inorganic and organic analyses for water and sediment samples and Missouri Department of Natural Resources drinking-water maximum contaminant levels (MCL)-Continued

\begin{tabular}{|c|c|c|c|}
\hline Group or famlly & Constltuent & MRL & MCL \\
\hline \multicolumn{4}{|c|}{ Volatile organic compounds (total), in water-Continued } \\
\hline \multirow[t]{5}{*}{ Substituted propane } & 1,2-Dichloropropane & $0.2 \mu \mathrm{g} / \mathrm{L}$ & $5 \mu \mathrm{g} / \mathrm{L}$ \\
\hline & 1,3-Dichloropropane & $.2 \mu \mathrm{g} / \mathrm{L}$ & $5 \mu \mathrm{g} / \mathrm{L}$ \\
\hline & 2,2-Dichloropropane & $.2 \mu \mathrm{g} / \mathrm{L}$ & -- \\
\hline & 1,2,3-Trichloropropane & $.2 \mu \mathrm{g} / \mathrm{L}$ & -- \\
\hline & 1,2-Dibromo-3-chloropropane (DBCP) & $.2 \mu \mathrm{g} / \mathrm{L}$ & $.2 \mu \mathrm{g} / \mathrm{L}$ \\
\hline \multirow[t]{3}{*}{ Substituted propene } & 1,1-Dichloropropene & $.2 \mu \mathrm{g} / \mathrm{L}$ & -- \\
\hline & cis-1,3-Dichloropropene & $.2 \mu \mathrm{g} / \mathrm{L}$ & -- \\
\hline & trans-1,3-Dichloropropene & $.2 \mu \mathrm{g} / \mathrm{L}$ & -- \\
\hline Substituted butene & Hexachlorobutadiene & $.2 \mu \mathrm{g} / \mathrm{L}$ & -- \\
\hline \multirow[t]{23}{*}{ Benzene derivatives } & Benzene & $.2 \mu \mathrm{g} / \mathrm{L}$ & $5 \mu \mathrm{g} / \mathrm{L}$ \\
\hline & Chlorobenzene & $.2 \mu \mathrm{g} / \mathrm{L}$ & $100 \mu \mathrm{g} / \mathrm{L}$ \\
\hline & 1,2-Dichlorobenzene & $.2 \mu \mathrm{g} / \mathrm{L}$ & $600 \mu \mathrm{g} / \mathrm{L}$ \\
\hline & 1,3-Dichlorobenzene & $.2 \mu \mathrm{g} / \mathrm{L}$ & $600 \mu \mathrm{g} / \mathrm{L}$ \\
\hline & 1,4-Dichlorobenzene & $.2 \mu \mathrm{g} / \mathrm{L}$ & $75 \mu \mathrm{g} / \mathrm{L}$ \\
\hline & 1,2,3-Trichlorobenzene & $.2 \mu \mathrm{g} / \mathrm{L}$ & -- \\
\hline & 1,2,4-Trichlorobenzene & $.2 \mu \mathrm{g} / \mathrm{L}$ & $70 \mu \mathrm{g} / \mathrm{L}$ \\
\hline & Bromobenzene & $.2 \mu \mathrm{g} / \mathrm{L}$ & -- \\
\hline & Ethylbenzene & $.2 \mu \mathrm{g} / \mathrm{L}$ & $70 \mu \mathrm{g} / \mathrm{L}$ \\
\hline & Isopropylbenzene & $.2 \mu \mathrm{g} / \mathrm{L}$ & -- \\
\hline & $n$-Propylbenzene & $.2 \mu \mathrm{g} / \mathrm{L}$ & -- \\
\hline & Sec-butylbenzene & $.2 \mu \mathrm{g} / \mathrm{L}$ & -- \\
\hline & Tert-butylbenzene & $.2 \mu \mathrm{g} / \mathrm{L}$ & -- \\
\hline & $n$-Butylbenzene & $.2 \mu \mathrm{g} / \mathrm{L}$ & -- \\
\hline & 1,2,4-Trimethylbenzene & $.2 \mu \mathrm{g} / \mathrm{L}$ & -- \\
\hline & 1,3,5-Trimethylbenzene & $.2 \mu \mathrm{g} / \mathrm{L}$ & -- \\
\hline & Xylenes, total & $.2 \mu \mathrm{g} / \mathrm{L}$ & $10 \mu \mathrm{g} / \mathrm{L}$ \\
\hline & Styrene & $.2 \mu \mathrm{g} / \mathrm{L}$ & $100 \mu \mathrm{g} / \mathrm{L}$ \\
\hline & Toluene & $.2 \mu \mathrm{g} / \mathrm{L}$ & $1 \mu \mathrm{g} / \mathrm{L}$ \\
\hline & 1,2-Chlorotoluene & $.2 \mu \mathrm{g} / \mathrm{L}$ & - \\
\hline & 1,4-Chlorotoluene & $.2 \mu \mathrm{g} / \mathrm{L}$ & -- \\
\hline & $p$-Isopropyltoluene & $.2 \mu \mathrm{g} / \mathrm{L}$ & - \\
\hline & Naphthalene & $.2 \mu \mathrm{g} / \mathrm{L}$ & -- \\
\hline \multirow[t]{3}{*}{ Ether } & 2-Chloroethylvinyl ether & $.2 \mu \mathrm{g} / \mathrm{L}$ & -- \\
\hline & Ethyl ether & $.2 \mu \mathrm{g} / \mathrm{L}$ & -- \\
\hline & Methyltertiarybutyl ether (MTBE) & $.2 \mu \mathrm{g} / \mathrm{L}$ & -- \\
\hline Aldehyde & Acrolein & $20 \mu \mathrm{g} / \mathrm{L}$ & -- \\
\hline \multirow[t]{4}{*}{ Ketone } & Acetone & $5 \mu \mathrm{g} / \mathrm{L}$ & -- \\
\hline & 2-Butanone (Methyl ethyl ketone) & $<20$ & -- \\
\hline & 2-Hexanone (Methyl butyl ketone) & $<20$ & -- \\
\hline & 4-Methyl-2-pentanone (MIBK) & $<20$ & -- \\
\hline Ester & Vinyl acetate & $.2 \mu \mathrm{g} / \mathrm{L}$ & -- \\
\hline Nitrile & Acrylonitrile & $20 \mu \mathrm{g} / \mathrm{L}$ & -. \\
\hline \multicolumn{4}{|c|}{ Semivolatile organic compounds (total), in water } \\
\hline \multirow[t]{7}{*}{ Acidic } & 2-Chlorophenol & $5 \mu \mathrm{g} / \mathrm{L}$ & -- \\
\hline & 2,4-Dichlorophenol & $30 \mu \mathrm{g} / \mathrm{L}$ & -- \\
\hline & 2,4-Dimethylphenol & $5 \mu \mathrm{g} / \mathrm{L}$ & -- \\
\hline & 4,6-Dinitro-ortho-cresol & $30 \mu \mathrm{g} / \mathrm{L}$ & -- \\
\hline & 2,4-Dinitrophenol & $20 \mu \mathrm{g} / \mathrm{L}$ & -- \\
\hline & 2-Nitrophenol & $5 \mu \mathrm{g} / \mathrm{L}$ & -- \\
\hline & 4-Nitrophenol & $30 \mu \mathrm{g} / \mathrm{L}$ & -- \\
\hline
\end{tabular}


Table 19. Constituents and detection limits of inorganic and organic analyses for water and sediment samples and Missouri Department of Natural Resources drinking-water maximum contaminant levels (MCL)-Continued

\begin{tabular}{|c|c|c|c|}
\hline Group or famlly & Constituent & MRL & MCL \\
\hline \multicolumn{4}{|c|}{ Semivolatile organic compounds (total), in water-Continued } \\
\hline \multirow[t]{4}{*}{ Acidic-Continued } & Para-chloro-meta cresol & $30 \mu \mathrm{g} / \mathrm{L}$ & - \\
\hline & Pentachlorophenol & $30 \mu \mathrm{g} / \mathrm{L}$ & $1 \mu \mathrm{g} / \mathrm{L}$ \\
\hline & Phenol & $5 \mu \mathrm{g} / \mathrm{L}$ & -- \\
\hline & 2,4,6-Trichlorophenol & $20 \mu \mathrm{g} / \mathrm{L}$ & -- \\
\hline \multirow[t]{45}{*}{ Basic and neutral } & Acenaphthene & $5 \mu \mathrm{g} / \mathrm{L}$ & -- \\
\hline & Acenaphthylene & $5 \mu \mathrm{g} / \mathrm{L}$ & -- \\
\hline & Anthracene & $5 \mu \mathrm{g} / \mathrm{L}$ & -- \\
\hline & Benzidine & $40 \mu \mathrm{g} / \mathrm{L}$ & -- \\
\hline & Benzo $[a]$ anthracene & $10 \mu \mathrm{g} / \mathrm{L}$ & $.1 \mu \mathrm{g} / \mathrm{L}$ \\
\hline & Benzo $[a]$ pyrene & $10 \mu \mathrm{g} / \mathrm{L}$ & $.2 \mu \mathrm{g} / \mathrm{L}$ \\
\hline & Benzo $[b]$ fluoranthene & $10 \mu \mathrm{g} / \mathrm{L}$ & $.2 \mu \mathrm{g} / \mathrm{L}$ \\
\hline & Benzo $[g, h, i]$ perylene & $10 \mu \mathrm{g} / \mathrm{L}$ & -- \\
\hline & Benzo $[k]$ fluoranthene & $10 \mu \mathrm{g} / \mathrm{L}$ & $.2 \mu \mathrm{g} / \mathrm{L}$ \\
\hline & bis(2-Chloroethoxy)methane & $5 \mu \mathrm{g} / \mathrm{L}$ & -- \\
\hline & bis(2-Chloroethyl) ether & $5 \mu \mathrm{g} / \mathrm{L}$ & -- \\
\hline & bis(2-Chloroisopropyl) ether & $5 \mu \mathrm{g} / \mathrm{L}$ & -- \\
\hline & bis(2-Ethylhexyl)phthalate & $5 \mu \mathrm{g} / \mathrm{L}$ & -- \\
\hline & 4-Bromophenyl phenyl ether & $5 \mu \mathrm{g} / \mathrm{L}$ & - \\
\hline & n-Butylbenzyl phthalate & $5 \mu \mathrm{g} / \mathrm{L}$ & $100 \mu \mathrm{g} / \mathrm{L}$ \\
\hline & 2-Chloronaphthalene & $5 \mu \mathrm{g} / \mathrm{L}$ & -- \\
\hline & 4-Chlorophenly phenyl ether & $5 \mu \mathrm{g} / \mathrm{L}$ & - \\
\hline & Chrysene & $10 \mu \mathrm{g} / \mathrm{L}$ & $.2 \mu \mathrm{g} / \mathrm{L}$ \\
\hline & 1,2,5,6-Dibenzanthracene & $10 \mu \mathrm{g} / \mathrm{L}$ & $.3 \mu \mathrm{g} / \mathrm{L}$ \\
\hline & 1,2-Dichlorobenzene & $5 \mu \mathrm{g} / \mathrm{L}$ & $600 \mu \mathrm{g} / \mathrm{L}$ \\
\hline & 1,3-Dichlorobenzene & $5 \mu \mathrm{g} / \mathrm{L}$ & $600 \mu \mathrm{g} / \mathrm{L}$ \\
\hline & 1,4-Dichlorobenzene & $5 \mu \mathrm{g} / \mathrm{L}$ & $75 \mu \mathrm{g} / \mathrm{L}$ \\
\hline & 3,3'-Dichlorobenzidine & $20 \mu \mathrm{g} / \mathrm{L}$ & -- \\
\hline & Diethylphthalate & $5 \mu \mathrm{g} / \mathrm{L}$ & -- \\
\hline & Dimethylphthalate & $5 \mu \mathrm{g} / \mathrm{L}$ & -- \\
\hline & Di-n-butyl phthalate & $5 \mu \mathrm{g} / \mathrm{L}$ & -- \\
\hline & 2,4-Dinitrotoluene & $5 \mu \mathrm{g} / \mathrm{L}$ & -- \\
\hline & 2,6-Dinitrotoluene & $5 \mu \mathrm{g} / \mathrm{L}$ & -- \\
\hline & Di-n-octyl phthalate & $10 \mu \mathrm{g} / \mathrm{L}$ & -- \\
\hline & 1,2-Diphenylhydrazine & $5 \mu \mathrm{g} / \mathrm{L}$ & -- \\
\hline & Fluoranthene & $5 \mu \mathrm{g} / \mathrm{L}$ & -- \\
\hline & Fluorene & $5 \mu \mathrm{g} / \mathrm{L}$ & -- \\
\hline & Hexachlorobenzene & $5 \mu \mathrm{g} / \mathrm{L}$ & $1 \mu \mathrm{g} / \mathrm{L}$ \\
\hline & Hexachlorobutadiene & $5 \mu \mathrm{g} / \mathrm{L}$ & -- \\
\hline & Hexachlorocyclopentadiene & $5 \mu \mathrm{g} / \mathrm{L}$ & $50 \mu \mathrm{g} / \mathrm{L}$ \\
\hline & Indeno $[1,2,3-c d]$ pyrene & $10 \mu \mathrm{g} / \mathrm{L}$ & $.4 \mu \mathrm{g} / \mathrm{L}$ \\
\hline & Isophorone & $5 \mu \mathrm{g} / \mathrm{L}$ & -- \\
\hline & Naphthalene & $5 \mu \mathrm{g} / \mathrm{L}$ & -- \\
\hline & Nitrobenzene & $5 \mu \mathrm{g} / \mathrm{L}$ & -- \\
\hline & n-Nitrosodimethylamine & $5 \mu \mathrm{g} / \mathrm{L}$ & -- \\
\hline & $n$-Nitrosodi-n-propylamine & $5 \mu \mathrm{g} / \mathrm{L}$ & -- \\
\hline & n-Nitrosodiphenylamine & $5 \mu \mathrm{g} / \mathrm{L}$ & -- \\
\hline & Phenanthrene & $5 \mu \mathrm{g} / \mathrm{L}$ & -- \\
\hline & Pyrene & $5 \mu \mathrm{g} / \mathrm{L}$ & -- \\
\hline & 1,2,4-Trichlorobenzene & $5 \mu \mathrm{g} / \mathrm{L}$ & $70 \mu \mathrm{g} / \mathrm{L}$ \\
\hline
\end{tabular}


Table 19. Constituents and detection limits of inorganic and organic analyses for water and sediment samples and Missouri Department of Natural Resources drinking-water maximum contaminant levels (MCL) - Continued

\begin{tabular}{|c|c|c|c|}
\hline Group or family & Constltuent & MRL & MCL \\
\hline \multicolumn{4}{|c|}{ Pesticides (dissolved), in water } \\
\hline Acetanilide & Alachlor & $0.009 \mu \mathrm{g} / \mathrm{L}$ & $2 \mu \mathrm{g} / \mathrm{L}$ \\
\hline \multirow[t]{2}{*}{ Amide } & Napropamide & $.01 \mu \mathrm{g} / \mathrm{L}$ & -- \\
\hline & Propanil & $.016 \mu \mathrm{g} / \mathrm{L}$ & -- \\
\hline Benzamide & Pronamide & $.009 \mu \mathrm{g} / \mathrm{L}$ & -- \\
\hline Benzenamine & Ethalfluralin & $.013 \mu \mathrm{g} / \mathrm{L}$ & -- \\
\hline \multirow[t]{6}{*}{ Carbamate } & Butylate & $.008 \mu \mathrm{g} / \mathrm{L}$ & -- \\
\hline & Carbaryl & $.046 \mu \mathrm{g} / \mathrm{L}$ & -- \\
\hline & Carbofuran & $.013 \mu \mathrm{g} / \mathrm{L}$ & $40 \mu \mathrm{g} / \mathrm{L}$ \\
\hline & EPTC (Eptam) & $.005 \mu \mathrm{g} / \mathrm{L}$ & -- \\
\hline & Pebulate & $.009 \mu \mathrm{g} / \mathrm{L}$ & -- \\
\hline & Thiobencarb & $.008 \mu \mathrm{g} / \mathrm{L}$ & - \\
\hline Carbothioate & Molinate & $.007 \mu \mathrm{g} / \mathrm{L}$ & -- \\
\hline \multirow[t]{2}{*}{ Chloractetanilide } & Metolachlor & $.009 \mu \mathrm{g} / \mathrm{L}$ & $\mathrm{L}$ \\
\hline & Propachlor & $.015 \mu \mathrm{g} / \mathrm{L}$ & -- \\
\hline \multirow[t]{2}{*}{ Cyclohexane } & Alpha BHC & $.007 \mu \mathrm{g} / \mathrm{L}$ & -- \\
\hline & Lindane & $.011 \mu \mathrm{g} / \mathrm{L}$ & $.2 \mu \mathrm{g} / \mathrm{L}$ \\
\hline \multirow[t]{2}{*}{ Dichloroethylene } & 2,6-Diethylaniline & $.006 \mu \mathrm{g} / \mathrm{L}$ & -- \\
\hline & $p, p^{\prime}-\mathrm{DDE}$ & $.01 \mu \mathrm{g} / \mathrm{L}$ & -- \\
\hline \multirow[t]{2}{*}{ Dinitroaniline } & Pendimethalin & $.018 \mu \mathrm{g} / \mathrm{L}$ & -- \\
\hline & Trifluralin & $.012 \mu \mathrm{g} / \mathrm{L}$ & $\mathrm{L}$ \\
\hline Methyluracil & Terbacil & $.03 \mu \mathrm{g} / \mathrm{L}$ & -- \\
\hline Napthalene & Dieldrin & $.008 \mu \mathrm{g} / \mathrm{L}$ & -- \\
\hline \multirow[t]{6}{*}{ Organophosphate } & Ethoprop & $.012 \mu \mathrm{g} / \mathrm{L}$ & -- \\
\hline & Malathion & $.01 \mu \mathrm{g} / \mathrm{L}$ & -- \\
\hline & Methyl Parathion & $.035 \mu \mathrm{g} / \mathrm{L}$ & -- \\
\hline & Parathion & $.022 \mu \mathrm{g} / \mathrm{L}$ & -- \\
\hline & Phorate & $.011 \mu \mathrm{g} / \mathrm{L}$ & -- \\
\hline & Terbufos & $.012 \mu \mathrm{g} / \mathrm{L}$ & -- \\
\hline \multirow[t]{2}{*}{ Organophosphorus } & Disulfoton & $.008 \mu \mathrm{g} / \mathrm{L}$ & -- \\
\hline & Methyl azinphos & $.038 \mu \mathrm{g} / \mathrm{L}$ & - \\
\hline \multirow[t]{2}{*}{ Phosphonodithioate } & Fonofos & $.008 \mu \mathrm{g} / \mathrm{L}$ & -- \\
\hline & Dimethoate & $.024 \mu \mathrm{g} / \mathrm{L}$ & -- \\
\hline \multirow[t]{2}{*}{ Phosphorothioate } & Chlorpyrifos & $.005 \mu \mathrm{g} / \mathrm{L}$ & -- \\
\hline & Diazinon & $.008 \mu \mathrm{g} / \mathrm{L}$ & -- \\
\hline Pyrethroid & Permethrin & $.016 \mu \mathrm{g} / \mathrm{L}$ & -- \\
\hline \multirow[t]{2}{*}{ Substituted urea } & Linuron & $.039 \mu \mathrm{g} / \mathrm{L}$ & -- \\
\hline & Tebuthiuron & $.015 \mu \mathrm{g} / \mathrm{L}$ & -- \\
\hline Sulfite ester & Propargite & $.006 \mu \mathrm{g} / \mathrm{L}$ & -- \\
\hline Terepthalate/dimethyl & DCPA (Dacthal) & $.004 \mu \mathrm{g} / \mathrm{L}$ & $\mathrm{L}$ \\
\hline Thiocaramate & Triallate & $.008 \mu \mathrm{g} / \mathrm{L}$ & -- \\
\hline Toluidine & Benfluralin & $.013 \mu \mathrm{g} / \mathrm{L}$ & -- \\
\hline \multirow[t]{5}{*}{ Triazine } & Atrazine & $.017 \mu \mathrm{g} / \mathrm{L}$ & $3 \mu \mathrm{g} / \mathrm{L}$ \\
\hline & Cyanazine & $.013 \mu \mathrm{g} / \mathrm{L}$ & -- \\
\hline & Deethylatrazine & $.007 \mu \mathrm{g} / \mathrm{L}$ & -- \\
\hline & Prometon & $.008 \mu \mathrm{g} / \mathrm{L}$ & L \\
\hline & Simazine & $.008 \mu \mathrm{g} / \mathrm{L}$ & $4 \mu \mathrm{g} / \mathrm{L}$ \\
\hline Triazinone & Metribuzin & $.012 \mu \mathrm{g} / \mathrm{L}$ & $\mathrm{L}$ \\
\hline
\end{tabular}


Table 19. Constituents and detection limits of inorganic and organic analyses for water and sediment samples and Missouri Department of Natural Resources drinking-water maximum contaminant levels (MCL)-Continued

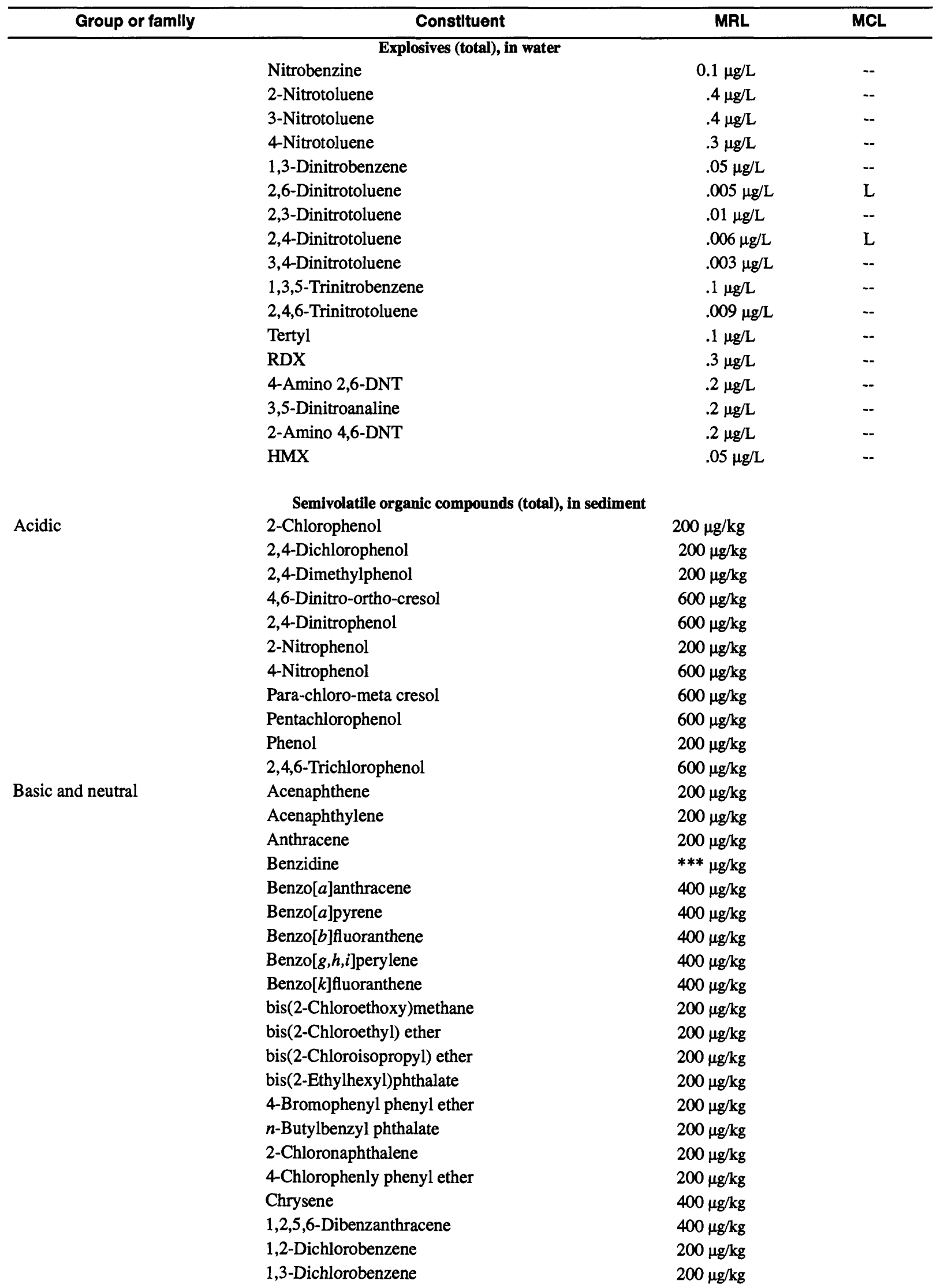


Table 19. Constituents and detection limits of inorganic and organic analyses for water and sediment samples and Missouri Department of Natural Resources drinking-water maximum contaminant levels (MCL)-Continued

\begin{tabular}{|c|c|c|c|}
\hline Group or famlly & Constituent & MRL & MCL \\
\hline \multicolumn{4}{|c|}{ Semivolatile organic compounds (total), in sediment-Continued } \\
\hline \multirow[t]{24}{*}{ Basic and neutral- - Continued } & 1,4-Dichlorobenzene & $200 \mu \mathrm{g} / \mathrm{kg}$ & \\
\hline & 3,3'-Dichlorobenzidine & $* * * \mu \mathrm{g} / \mathrm{kg}$ & \\
\hline & Diethylphthalate & $200 \mu \mathrm{g} / \mathrm{kg}$ & \\
\hline & Dimethylphthalate & $200 \mu \mathrm{g} / \mathrm{kg}$ & \\
\hline & Di-n-butyl phthalate & $200 \mu \mathrm{g} / \mathrm{kg}$ & \\
\hline & 2,4-Dinitrotoluene & $200 \mu \mathrm{g} / \mathrm{kg}$ & \\
\hline & 2,6-Dinitrotoluene & $200 \mu \mathrm{g} / \mathrm{kg}$ & \\
\hline & Di-n-octyl phthalate & $400 \mu \mathrm{g} / \mathrm{kg}$ & \\
\hline & 1,2-Diphenylhydrazine & $* * * \mu \mathrm{g} / \mathrm{kg}$ & \\
\hline & Fluoranthene & $200 \mu \mathrm{g} / \mathrm{kg}$ & \\
\hline & Fluorene & $200 \mu \mathrm{g} / \mathrm{kg}$ & \\
\hline & Hexachlorobenzene & $200 \mu \mathrm{g} / \mathrm{kg}$ & \\
\hline & Hexachlorobutadiene & $200 \mu \mathrm{g} / \mathrm{kg}$ & \\
\hline & Hexachlorocyclopentadiene & $200 \mu \mathrm{g} / \mathrm{kg}$ & \\
\hline & Indeno[ $[1,2,3-c d]$ pyrene & $400 \mu \mathrm{g} / \mathrm{kg}$ & \\
\hline & Isophorone & $200 \mu \mathrm{g} / \mathrm{kg}$ & \\
\hline & Naphthalene & $200 \mu \mathrm{g} / \mathrm{kg}$ & \\
\hline & Nitrobenzene & $200 \mu \mathrm{g} / \mathrm{kg}$ & \\
\hline & $n$-Nitrosodimethylamine & $200 \mu \mathrm{g} / \mathrm{kg}$ & \\
\hline & $n$-Nitrosodi-n-propylamine & $200 \mu \mathrm{g} / \mathrm{kg}$ & \\
\hline & $n$-Nitrosodiphenylamine & $200 \mu \mathrm{g} / \mathrm{kg}$ & \\
\hline & Phenanthrene & $200 \mu \mathrm{g} / \mathrm{kg}$ & \\
\hline & Pyrene & $200 \mu \mathrm{g} / \mathrm{kg}$ & \\
\hline & 1,2,4-Trichlorobenzene & $200 \mu \mathrm{g} / \mathrm{kg}$ & \\
\hline
\end{tabular}

Chlorophenoxy-acid herbicides, in sediment

$\begin{array}{lr}2,4,5-\mathrm{T} & 0.1 \mu \mathrm{g} / \mathrm{kg} \\ 2,4-\mathrm{D} & .1 \mu \mathrm{g} / \mathrm{kg} \\ 2,4-\mathrm{DP} & .1 \mu \mathrm{g} / \mathrm{kg} \\ \text { Dicamba } & .1 \mu \mathrm{g} / \mathrm{kg} \\ \text { Picloram } & .1 \mu \mathrm{g} / \mathrm{kg} \\ \text { Silvex } & .1 \mu \mathrm{g} / \mathrm{kg}\end{array}$

Explosives, in sediment

1,3-Dinitrobenzene

$0.25 \mathrm{mg} / \mathrm{kg}$

$.26 \mathrm{mg} / \mathrm{kg}$

$.25 \mathrm{mg} / \mathrm{kg}$

2,4-Dinitrotoluene

$.25 \mathrm{mg} / \mathrm{kg}$

1,3,5-Trinitrobenzene

$.25 \mathrm{mg} / \mathrm{kg}$

2,4,6-Trinitrotoluene

$.65 \mathrm{mg} / \mathrm{kg}$

RDX

4-Amino 2,6-DNT

$1.00 \mathrm{mg} / \mathrm{kg}$

$.26 \mathrm{mg} / \mathrm{kg}$

2-Amino 4,6-DNT

$.26 \mathrm{mg} / \mathrm{kg}$

HMX

$2.20 \mathrm{mg} / \mathrm{kg}$

TCDD, total

Dioxin, in sediment

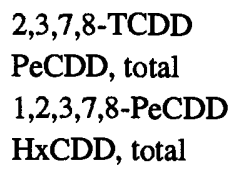

$0.013 \mathrm{ng} / \mathrm{g}$

$.013 \mathrm{ng} / \mathrm{g}$

$.036 \mathrm{ng} / \mathrm{g}$

$.036 \mathrm{ng} / \mathrm{g}$

$.026 \mathrm{ng} / \mathrm{g}$

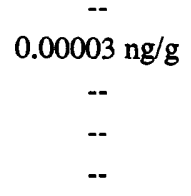


Table 19. Constituents and detection limits of inorganic and organic analyses for water and sediment samples and Missouri Department of Natural Resources drinking-water maximum contaminant levels (MCL)-Continued

\begin{tabular}{|c|c|c|c|}
\hline Group or famlly & Constltuent & $\overline{\text { MRL }}$ & MCL \\
\hline \multicolumn{4}{|c|}{ Dioxin, in sediment-Continued } \\
\hline & $1,2,3,4,7,8-\mathrm{HxCDD}$ & $0.026 \mathrm{ng} / \mathrm{g}$ & -- \\
\hline & $1,2,3,6,7,8-\mathrm{HxCDD}$ & $.026 \mathrm{ng} / \mathrm{g}$ & -- \\
\hline & 1,2,3,7,8,9-HxCDD & $.026 \mathrm{ng} / \mathrm{g}$ & -- \\
\hline & HpCDD, total & $.015 \mathrm{ng} / \mathrm{g}$ & -- \\
\hline & $1,2,3,4,6,7,8-\mathrm{HpCDD}$ & $.0073 \mathrm{ng} / \mathrm{g}$ & -- \\
\hline & OCDD & $.25 \mathrm{ng} / \mathrm{g}$ & -- \\
\hline \multicolumn{4}{|c|}{ Furan, in sediment } \\
\hline & TCDF, total & $0.067 \mathrm{ng} / \mathrm{g}$ & -- \\
\hline & $2,3,7,8-\mathrm{TCDF}$ & $.067 \mathrm{ng} / \mathrm{g}$ & -- \\
\hline & PeCDF, total & $.019 \mathrm{ng} / \mathrm{g}$ & -- \\
\hline & $1,2,3,7,8-\mathrm{PeCDF}$ & $.019 \mathrm{ng} / \mathrm{g}$ & -- \\
\hline & $2,3,4,7,8-\mathrm{PeCDF}$ & $.019 \mathrm{ng} / \mathrm{g}$ & -- \\
\hline & HxCDF, total & $.014 \mathrm{ng} / \mathrm{g}$ & -- \\
\hline & $1,2,3,4,7,8-\mathrm{HxCDF}$ & $.014 \mathrm{ng} / \mathrm{g}$ & -- \\
\hline & $1,2,3,6,7,8-\mathrm{HxCDF}$ & $.014 \mathrm{ng} / \mathrm{g}$ & -- \\
\hline & $2,3,4,6,7,8-\mathrm{HxCDF}$ & $.014 \mathrm{ng} / \mathrm{g}$ & -- \\
\hline & $1,2,3,7,8,9-\mathrm{HxCDF}$ & $.014 \mathrm{ng} / \mathrm{g}$ & -- \\
\hline & H-CDF, total & $.011 \mathrm{ng} / \mathrm{g}$ & -- \\
\hline & $1,2,3,4,6,7,8-\mathrm{HpCDF}$ & $.011 \mathrm{ng} / \mathrm{g}$ & -- \\
\hline & $1,2,3,4,7,8,9-\mathrm{HpCDF}$ & $.011 \mathrm{ng} / \mathrm{g}$ & -- \\
\hline & OCDF & $.032 \mathrm{ng} / \mathrm{g}$ & -- \\
\hline
\end{tabular}


Table 20. Quality-assurance data for physical properties and inorganic constituents in duplicate and blank water samples

[RPD, relative percent difference; <, less than; --, no data available]

\begin{tabular}{|c|c|c|c|}
\hline Physical property or constituent & $\begin{array}{l}\text { Median RPD } \\
\text { of duplicates }\end{array}$ & $\begin{array}{c}\text { Median } \\
\text { blank value }\end{array}$ & $\begin{array}{c}\text { Maximum } \\
\text { blank value }\end{array}$ \\
\hline Specific conductance, in microsiemens per centimeter & $<1$ & 2 & $\overline{6}$ \\
\hline $\mathrm{pH}$, in standard units & 1.4 & 7.8 & 8.0 \\
\hline Calcium, in milligrams per liter & $<1$ & $<.04$ & .05 \\
\hline Calcium, total, in milligrams per liter & 3 & .04 & .1 \\
\hline Magnesium, in milligrams per liter & $<1$ & $<.02$ & .02 \\
\hline Magnesium, total, in milligrams per liter & $<1$ & $<.03$ & .04 \\
\hline Sodium, in milligrams per liter & $<1$ & $<.2$ & $<.2$ \\
\hline Sodium, total, in milligrams per liter & $<1$ & .2 & .2 \\
\hline Potassium, in milligrams per liter & 1.4 & $<.1$ & .1 \\
\hline Alkalinity, incremental titration, total as $\mathrm{CaCO}_{3}$, in milligrams per liter & $<1$ & -- & -- \\
\hline Bicarbonate, in milligrams per liter & -- & -- & -- \\
\hline Alkalinity, $\mathrm{pH} 4.5$ endpoint, in milligrams per liter & $<1$ & -- & -- \\
\hline Chloride, in milligrams per liter & $<1$ & .2 & .7 \\
\hline Sulfate, in milligrams per liter & $<1$ & & \\
\hline Fluoride, in milligrams per liter & $<1$ & $<.1$ & $<.1$ \\
\hline Silica, in milligrams per liter & 1 & .3 & .4 \\
\hline Cyanide, in milligrams per liter & $<1$ & $<.02$ & $<.02$ \\
\hline Residue, loss upon ignition at 105 degrees Celsius, in milligrams per liter & 2.1 & 9 & 16 \\
\hline Total dissolved solids, in milligrams per liter & $<1$ & -- & -- \\
\hline Hardness, as $\mathrm{CaCO}_{3}$, in milligrams per liter & $<1$ & $<1$ & $<1$ \\
\hline Total organic carbon, in milligrams per liter & 3.9 & 1.4 & 6.2 \\
\hline Nitrite plus nitrate, total as nitrogen, in milligrams per liter & $<1$ & $<.02$ & .02 \\
\hline Nitrite, total as nitrogen, in milligrams per liter & $<1$ & $<.006$ & .01 \\
\hline Ammonia, total as nitrogen, in milligrams per liter & $<1$ & .01 & .04 \\
\hline Phosphorus, total, in milligrams per liter & 28 & $<.02$ & .02 \\
\hline Fecal coliform, in colonies per 100 milliliters & $<1$ & $<10$ & $<10$ \\
\hline Fecal streptococcus, in colonies per 100 milliliters & $<1$ & $<5$ & $<5$ \\
\hline Antimony, total, in micrograms per liter & $<1$ & $<1$ & 1 \\
\hline Arsenic, in micrograms per liter & $<1$ & $<1$ & 1 \\
\hline Barium, in micrograms per liter & $<1$ & $<2$ & $<2$ \\
\hline Barium, total, in micrograms per liter & $<1$ & $<2$ & 2 \\
\hline Beryllium, in micrograms per liter & $<1$ & $<.5$ & $<.5$ \\
\hline Beryllium, total, in micrograms per liter & $<1$ & $<.5$ & .5 \\
\hline Boron, in micrograms per liter & 33 & $<15$ & 20 \\
\hline Boron, total, in micrograms per liter & $<1$ & $<20$ & 20 \\
\hline Cadmium, in micrograms per liter & $<1$ & $<1$ & $<1$ \\
\hline Cadmium, total, in micrograms per liter & $<1$ & $<1$ & 1 \\
\hline Chromium, in micrograms per liter & $<1$ & $<5$ & $<5$ \\
\hline Chromium, total, in micrograms per liter & $<1$ & $<5$ & 5 \\
\hline Cobalt, in micrograms per liter & $<1$ & $<3$ & $<3$ \\
\hline Cobalt, total, in micrograms per liter & $<1$ & $<3$ & 3 \\
\hline
\end{tabular}


Table 20. Quality-assurance data for physical properties and inorganic constituents in duplicate and blank water samples-Continued

\begin{tabular}{lccc}
\hline \multicolumn{1}{c}{ Physical property or constituent } & $\begin{array}{c}\text { Median RPD } \\
\text { of duplicates }\end{array}$ & $\begin{array}{c}\text { Median } \\
\text { blank value }\end{array}$ & $\begin{array}{c}\text { Maximum } \\
\text { blank value }\end{array}$ \\
\hline Copper, in micrograms per liter & $<1$ & $<10$ & $<10$ \\
Copper, total, in micrograms per liter & $<1$ & $<10$ & 10 \\
Iron, in micrograms per liter & 13 & $<3$ & 7 \\
Iron, total, in micrograms per liter & $<1$ & $<3$ & 10 \\
Lithium, in micrograms per liter & $<1$ & $<4$ & $<4$ \\
Lead, in micrograms per liter & $<1$ & $<11$ & 50 \\
Lead, total, in micrograms per liter & $<1$ & $<10$ & 10 \\
Mercury, in micrograms per liter & $<1$ & $<.1$ & $<.1$ \\
Manganese, in micrograms per liter & $<1$ & $<1$ & $<1$ \\
Manganese, total, in micrograms per liter & $<1$ & $<1$ & 1 \\
Molybdenum, in micrograms per liter & $<1$ & $<10$ & $<10$ \\
Nickel, in micrograms per liter & $<1$ & $<10$ & $<10$ \\
Nickel, total, in micrograms per liter & $<1$ & $<10$ & 10 \\
Selenium, total, in micrograms per liter & $<1$ & $<1$ & $<1$ \\
Silver, in micrograms per liter & $<1$ & $<1$ & 3 \\
Silver, total, in micrograms per liter & $<1$ & $<1$ & 1 \\
Strontium, in micrograms per liter & $<1$ & $<1$ & $<1$ \\
Thallium, total, in micrograms per liter & $<1$ & $<1$ & $<1$ \\
Vanadium, in micrograms per liter & $<1$ & $<6$ & $<6$ \\
Vanadium, total, in micrograms per liter & $<1$ & $<1$ & 1 \\
Zinc, in micrograms per liter & $<1$ & $<8$ & 8 \\
Zinc, total, in micrograms per liter & $<1$ & $<4$ & 4 \\
\hline & & & \\
\hline
\end{tabular}




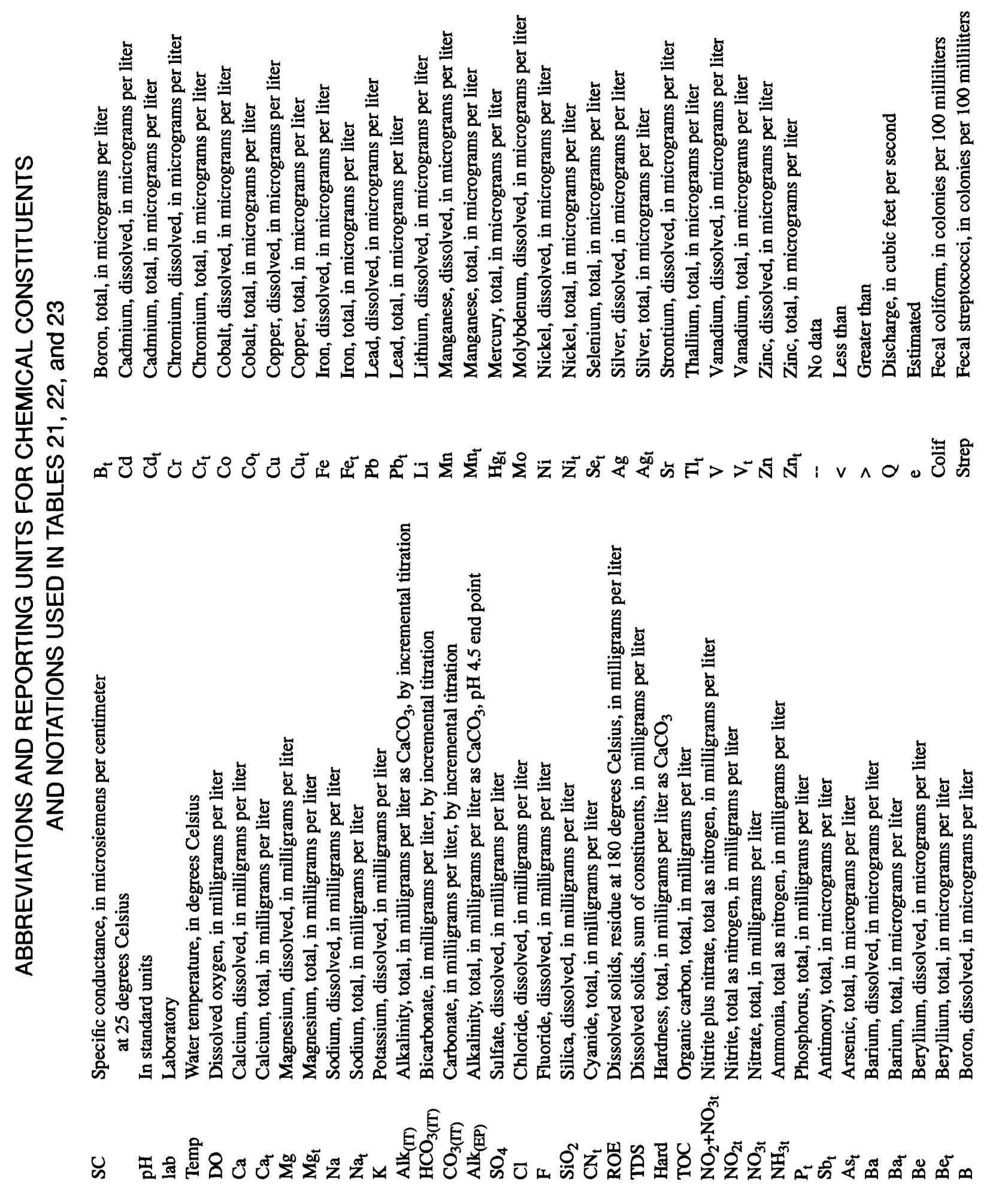




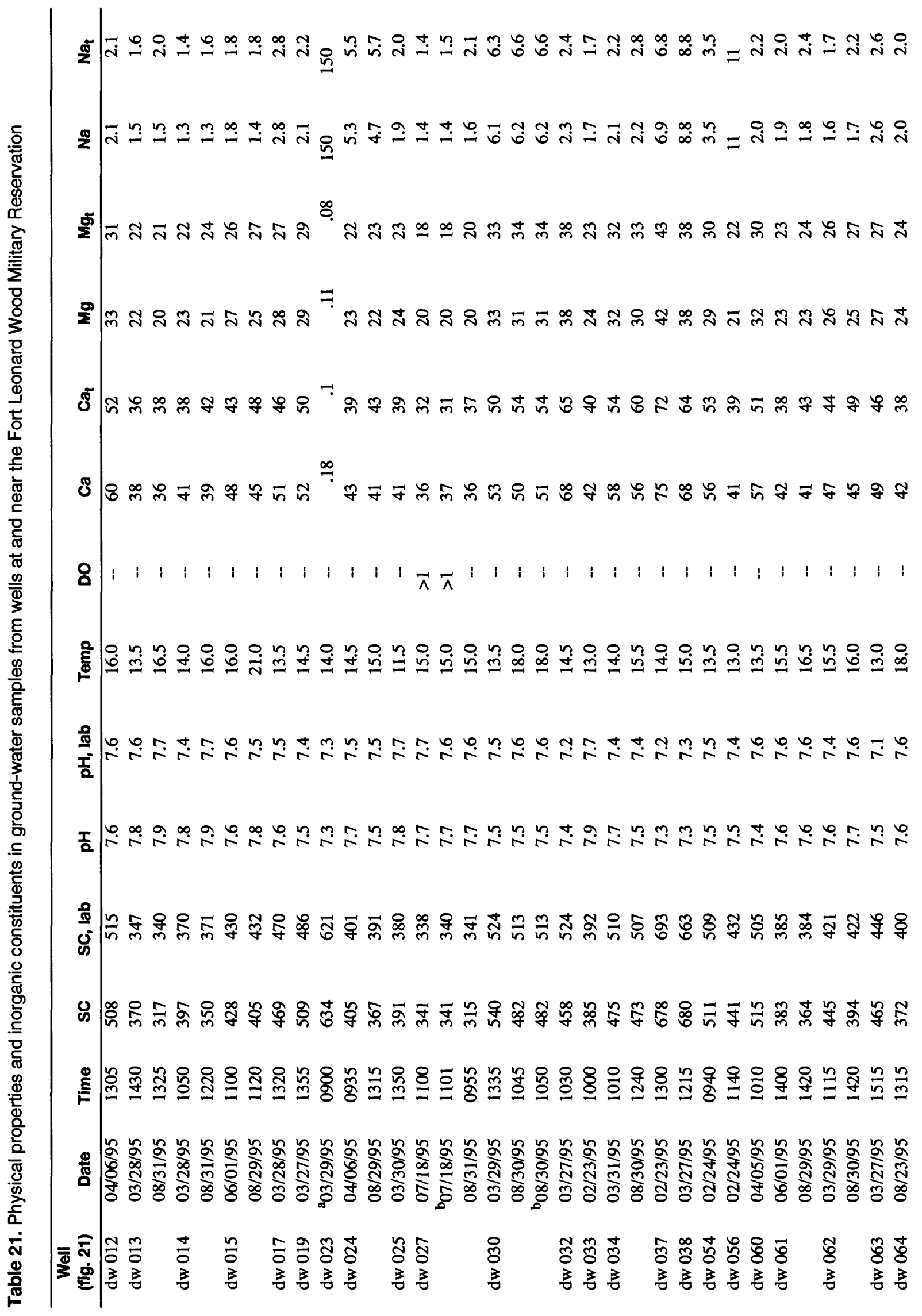




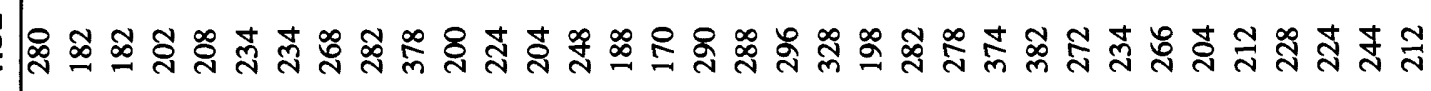

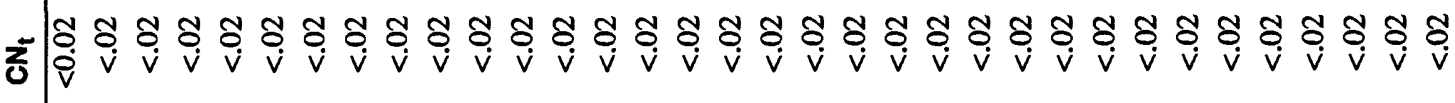

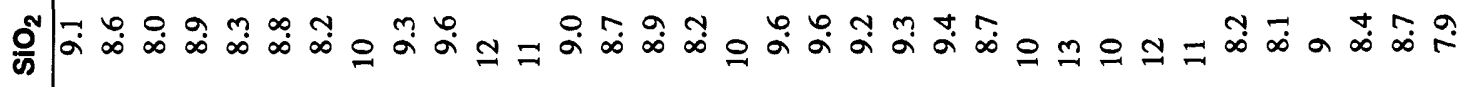

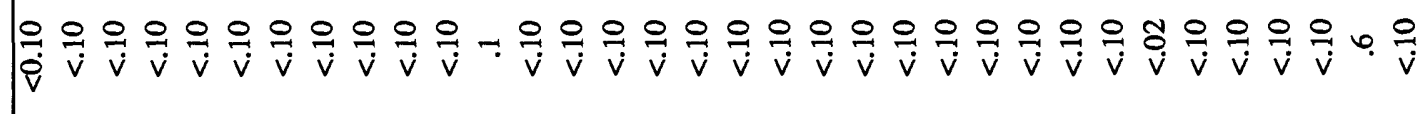

ర

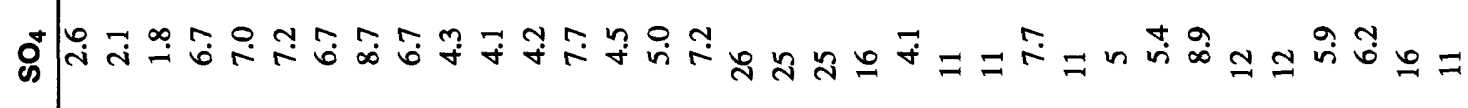

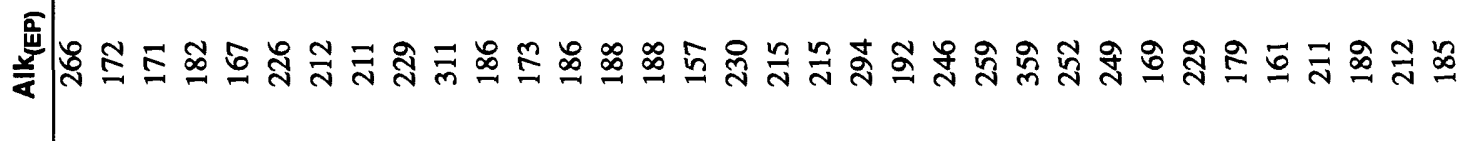

E़

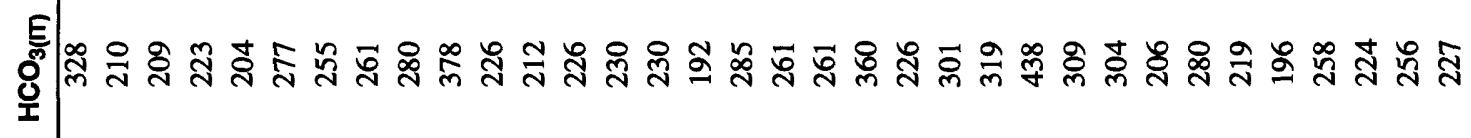

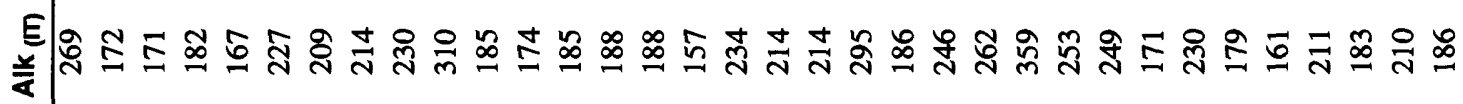
$x$ ำ

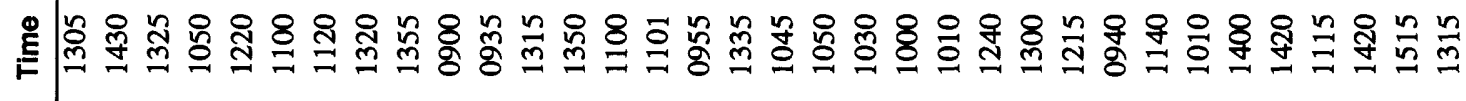

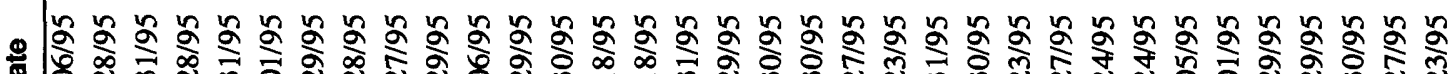

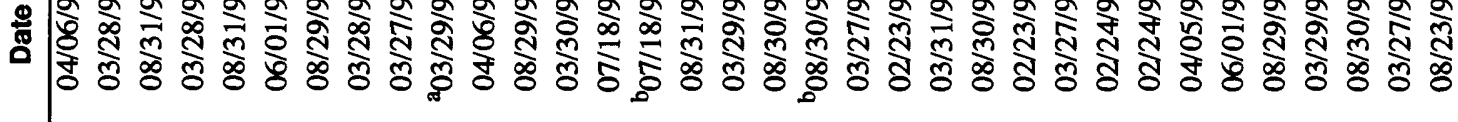

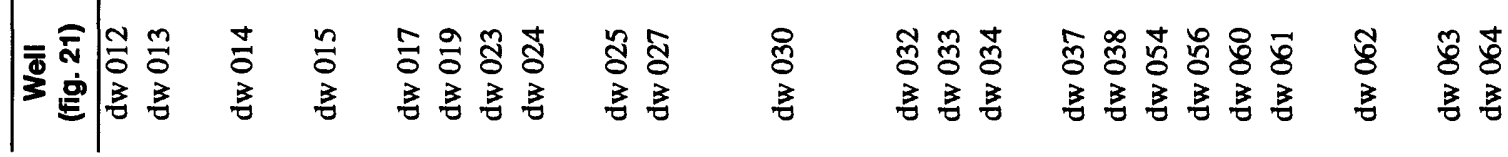




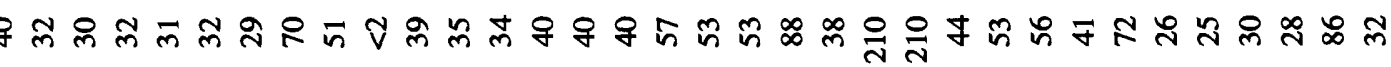

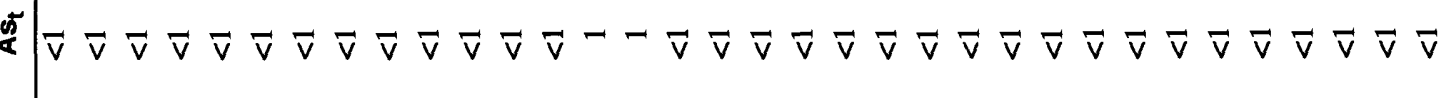

ङ $\vec{v} \vec{v} \vec{v} \vec{v} \vec{v}-\vec{v} \vec{v} \vec{v} \vec{v} \vec{v} \vec{v} \vec{v} \sim \vec{v} \vec{v} \vec{v} \vec{v} \vec{v} \vec{v} \vec{v} \vec{v} \vec{v} \vec{v} \vec{v} \vec{v}-\vec{v} \vec{v} \vec{v} \vec{v} \vec{v}$

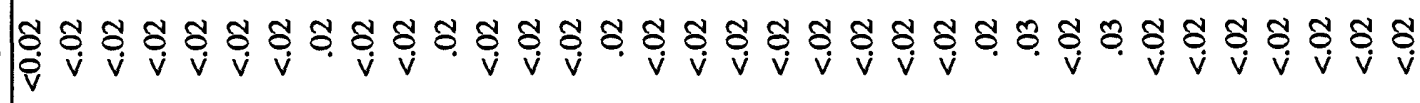

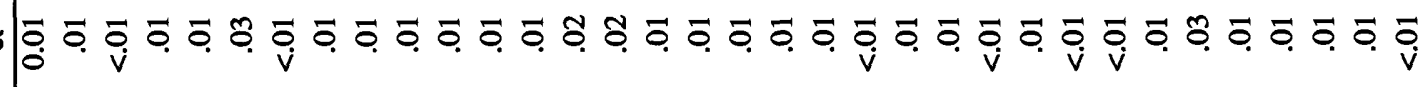

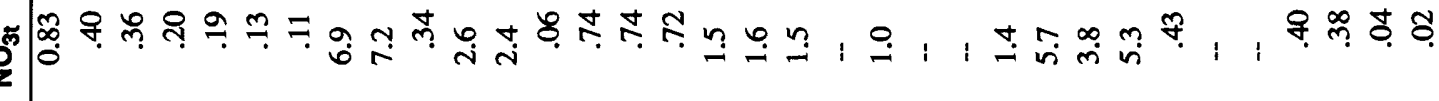

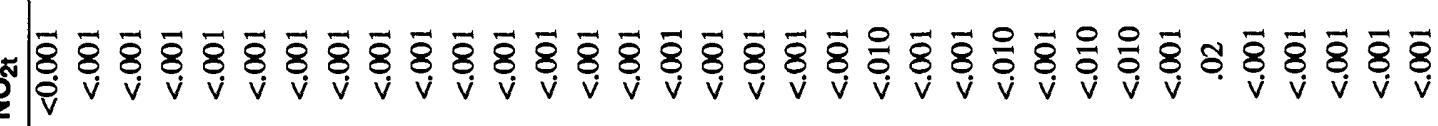

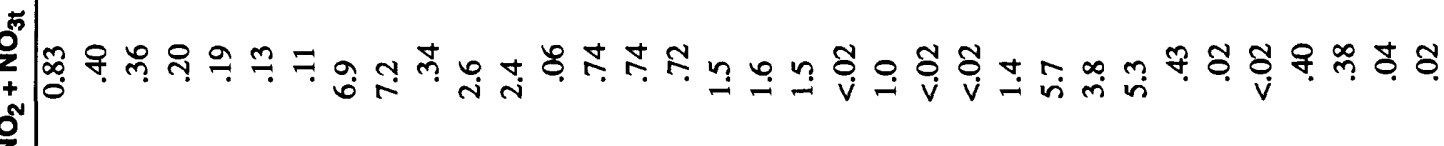

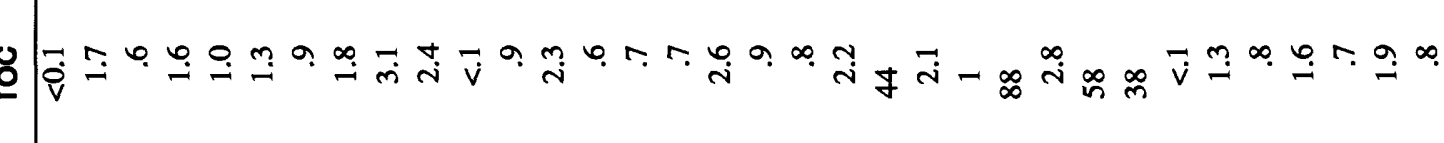

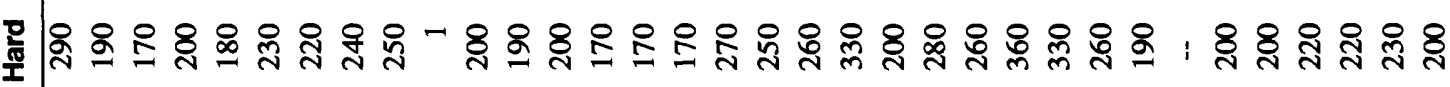

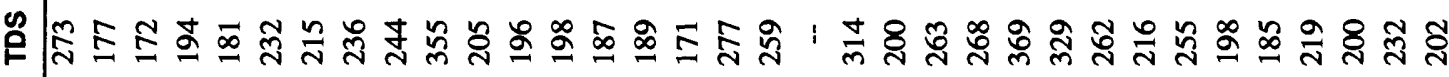

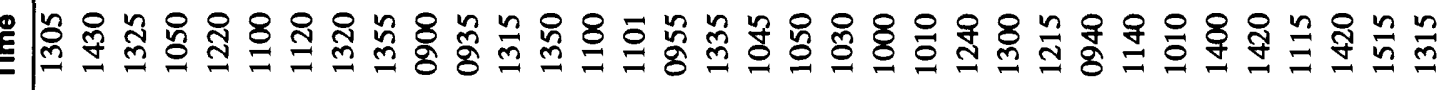

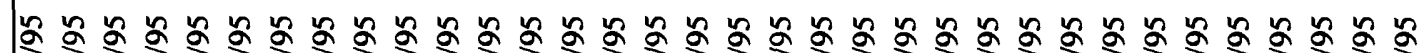

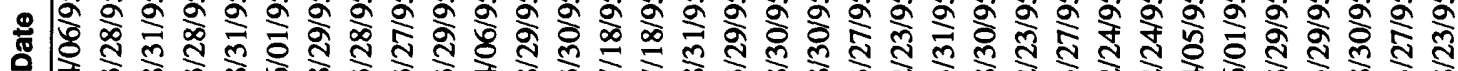

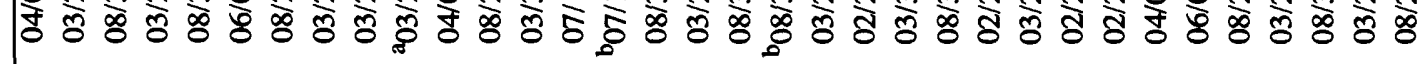

产

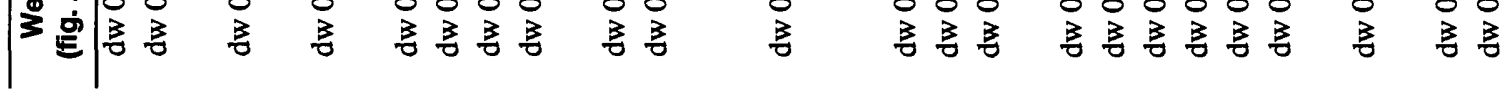




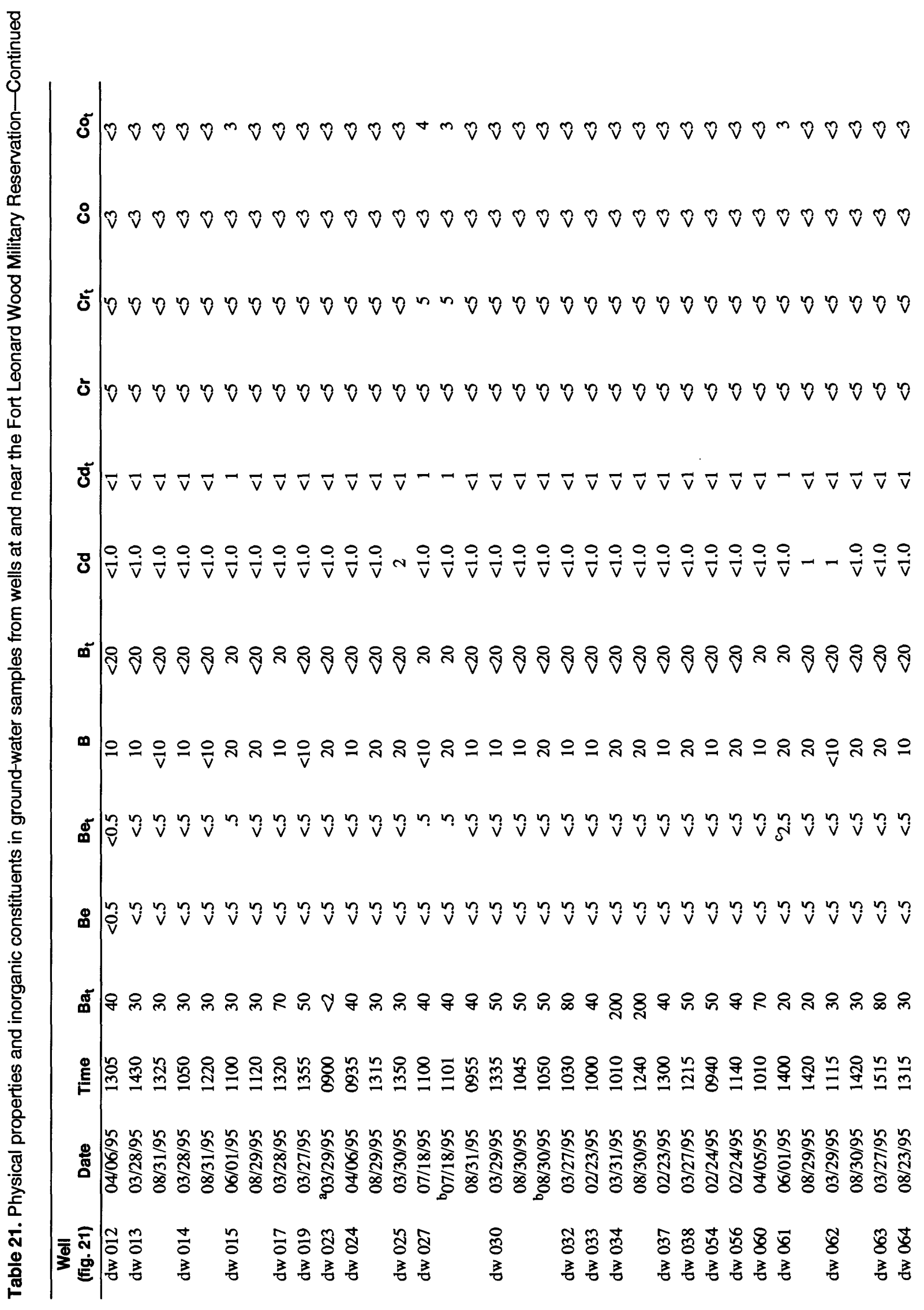




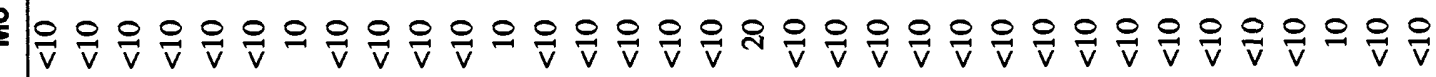

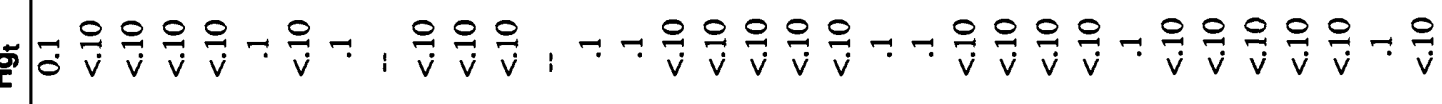

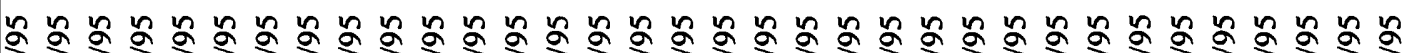
ปั

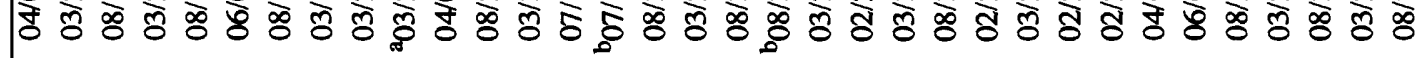

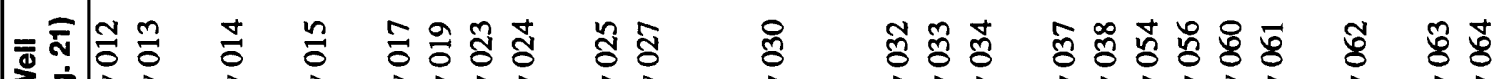

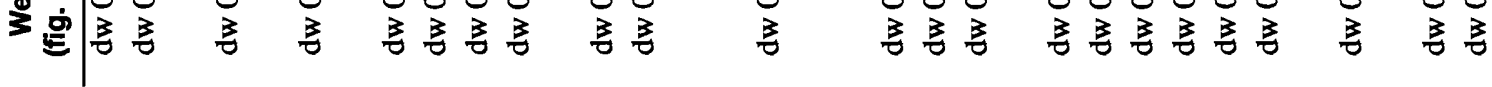




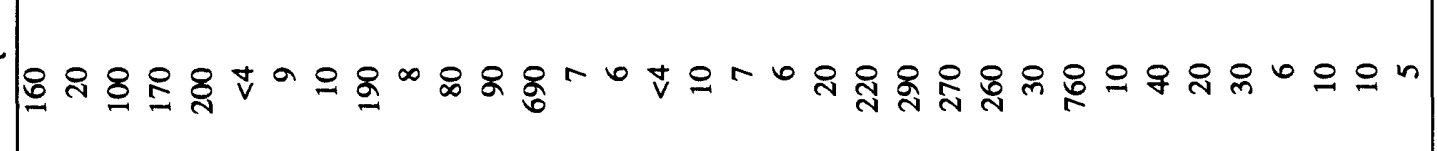

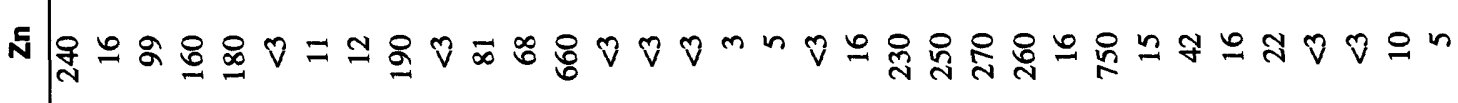

$\vec{v} \vec{v} \vec{v} \vec{v} \vec{v} \vec{v} \vec{v} \vec{v} \vec{v} \bar{v} \vec{v} \vec{v} \bar{v}-\vec{v} \vec{v} \vec{v} \vec{v} \vec{v} \vec{v} \vec{v} \vec{v} \vec{v} \vec{v} \vec{v} \bar{v} \vec{v} \vec{v} \vec{v} \vec{v} \vec{v} \vec{v} \vec{v}$

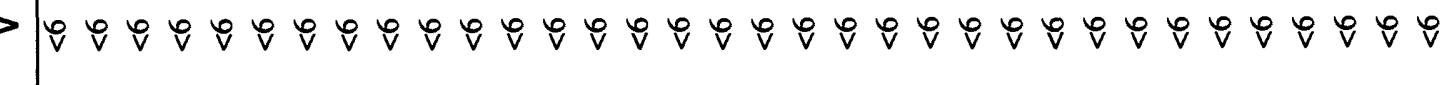

$\vec{F} \vec{v} \vec{v} \vec{v} \vec{v} \vec{v} \vec{v} \vec{v} \vec{v} \vec{v} \vec{v} \vec{v} \vec{v} \vec{v}-\vec{v} \vec{v} \vec{v} \vec{v} \vec{v} \vec{v} \vec{v} \vec{v} \vec{v} \vec{v} \vec{v} \vec{v} \vec{v} \vec{v} \vec{v} \vec{v} \vec{v} \vec{v} \vec{v}$

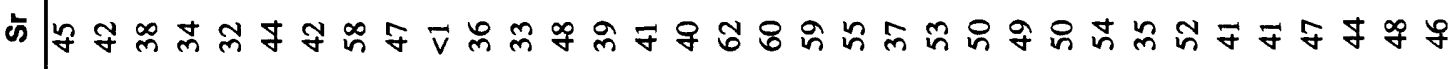

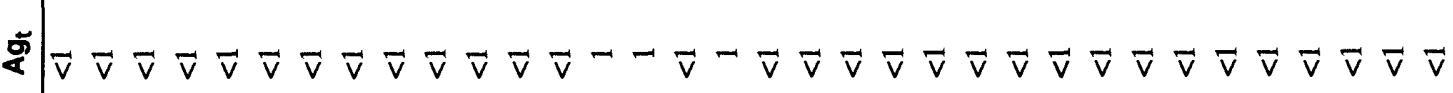

$\sqrt{2}$

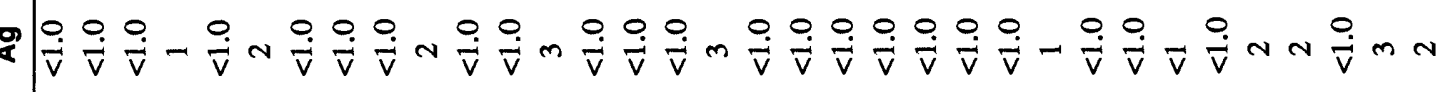

\$ $\vec{v} \vec{v} \vec{v} \vec{v} \vec{v} \vec{v} \vec{v} \vec{v} \vec{v} \vec{v} \vec{v} \vec{v} \vec{v} \vec{v} \vec{v} \vec{v} \vec{v} \vec{v} \vec{v} \vec{v} \vec{v} \vec{v} \vec{v} \vec{v} \vec{v} \vec{v} \vec{v} \vec{v} \vec{v} \vec{v} \vec{v} \vec{v} \vec{v} \vec{v}$

艺

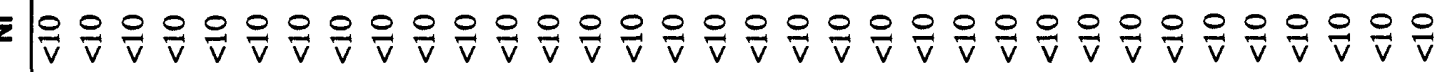

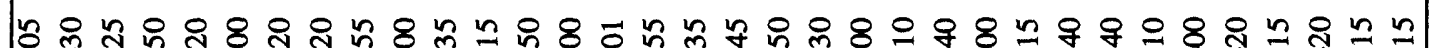

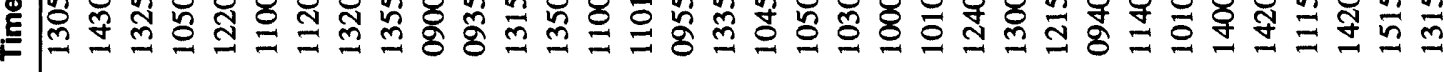

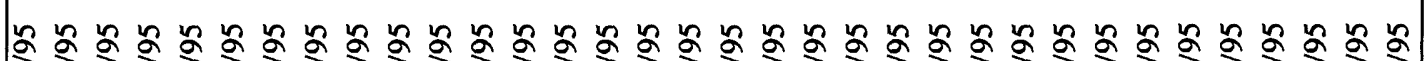
今̋

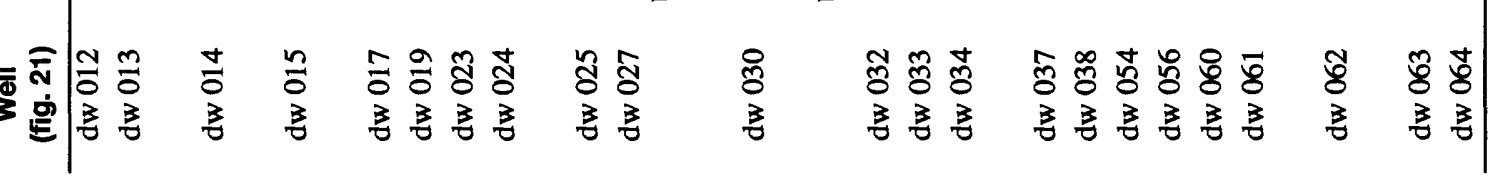




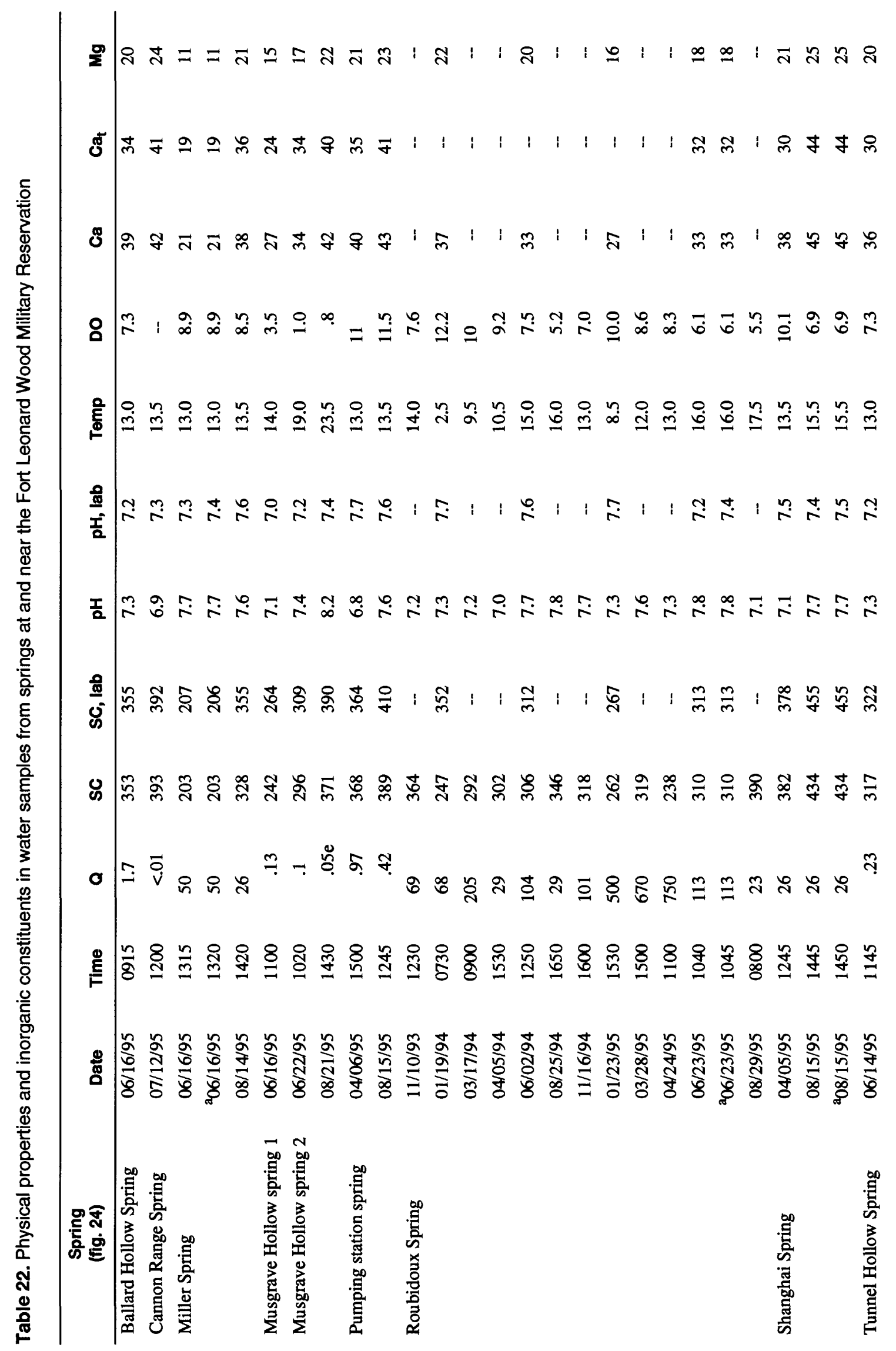




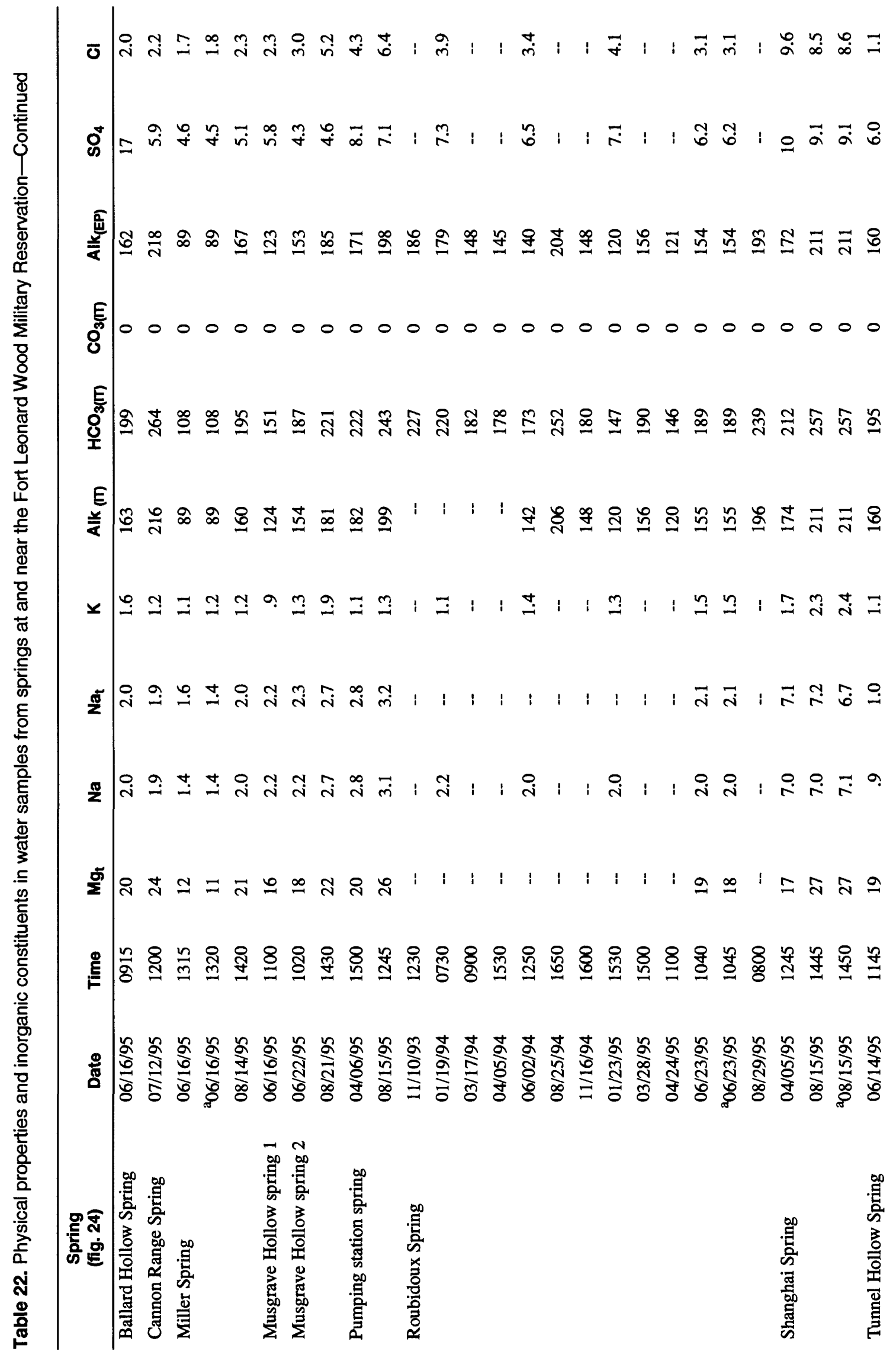




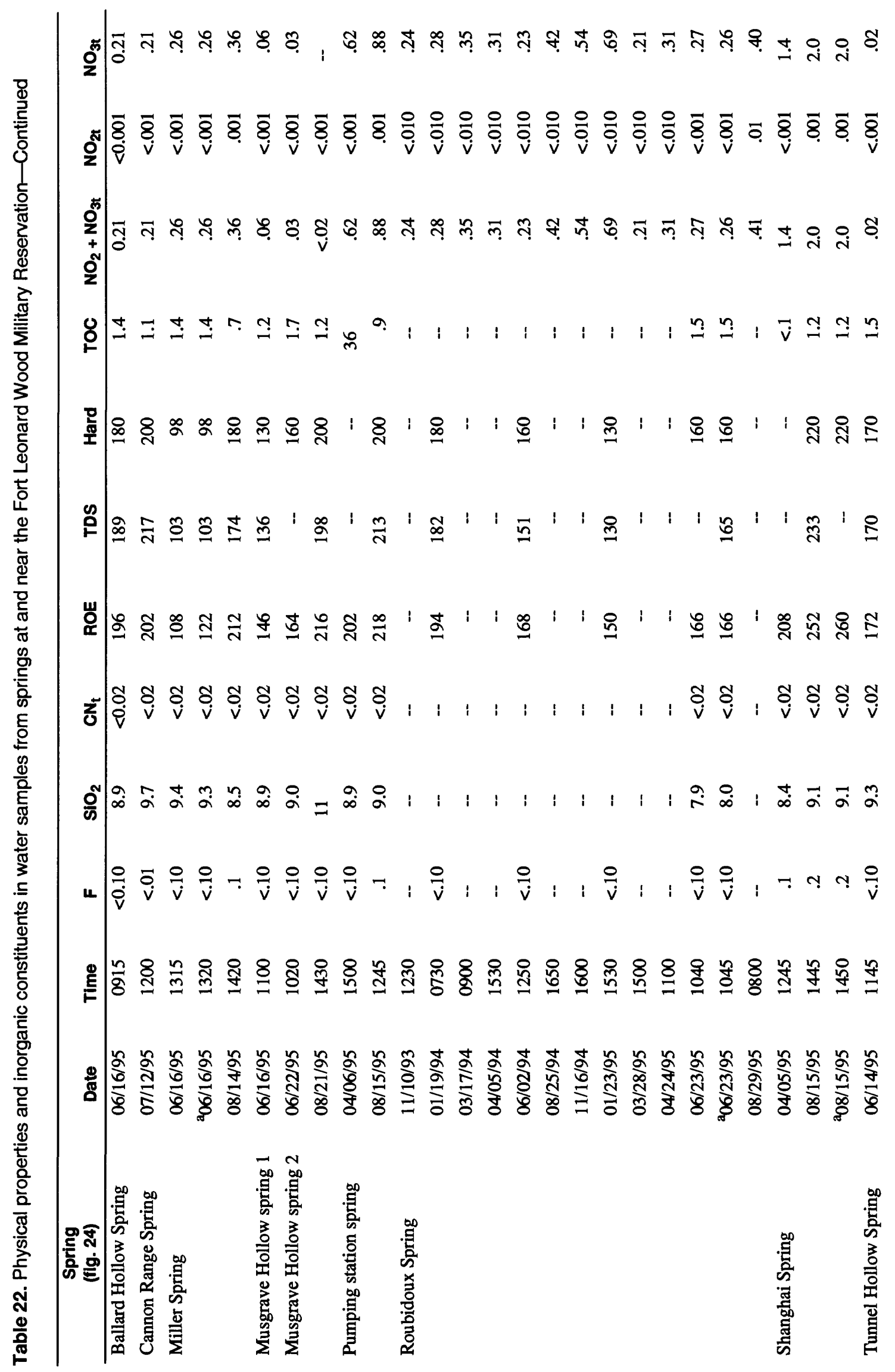




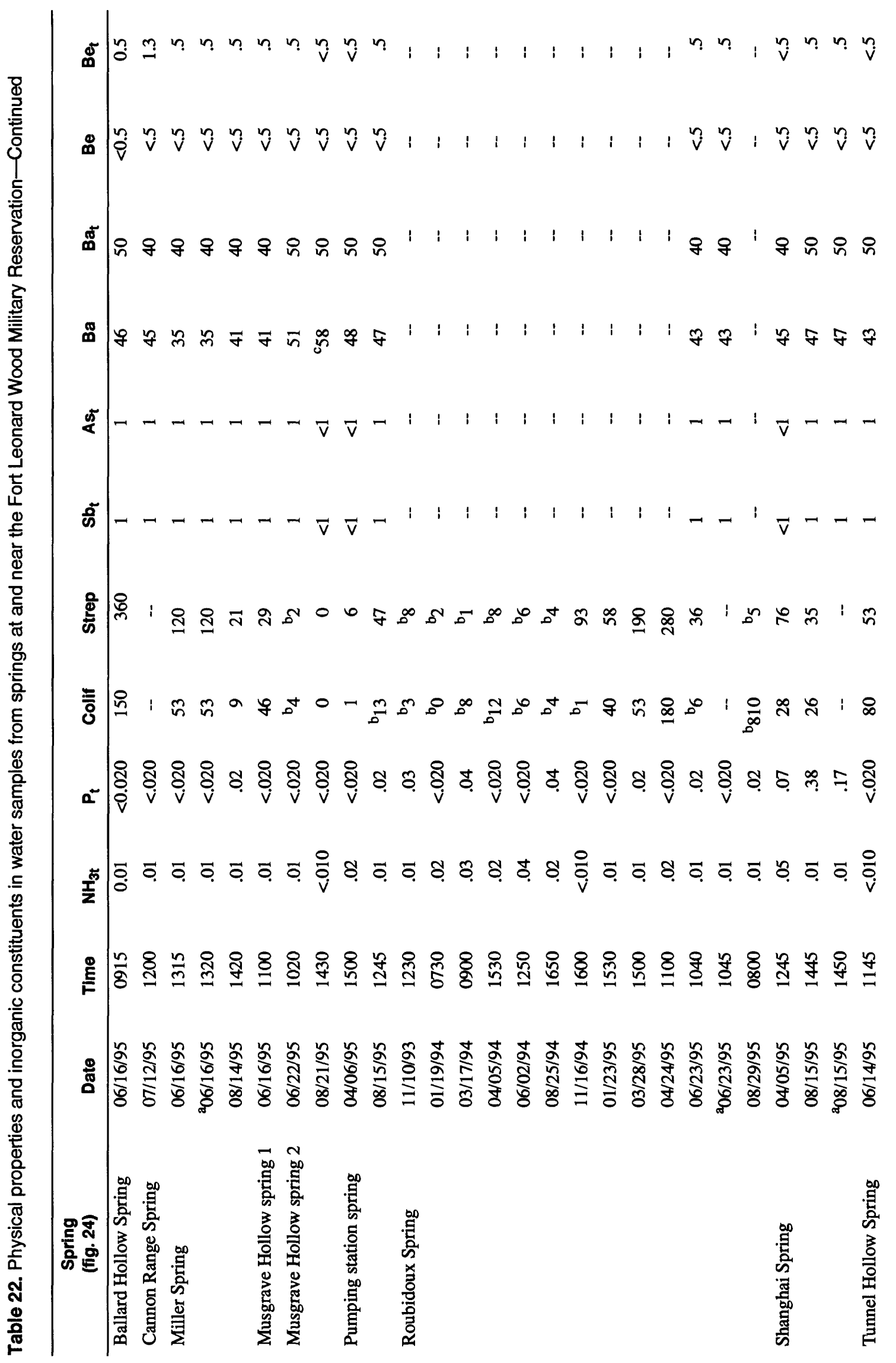




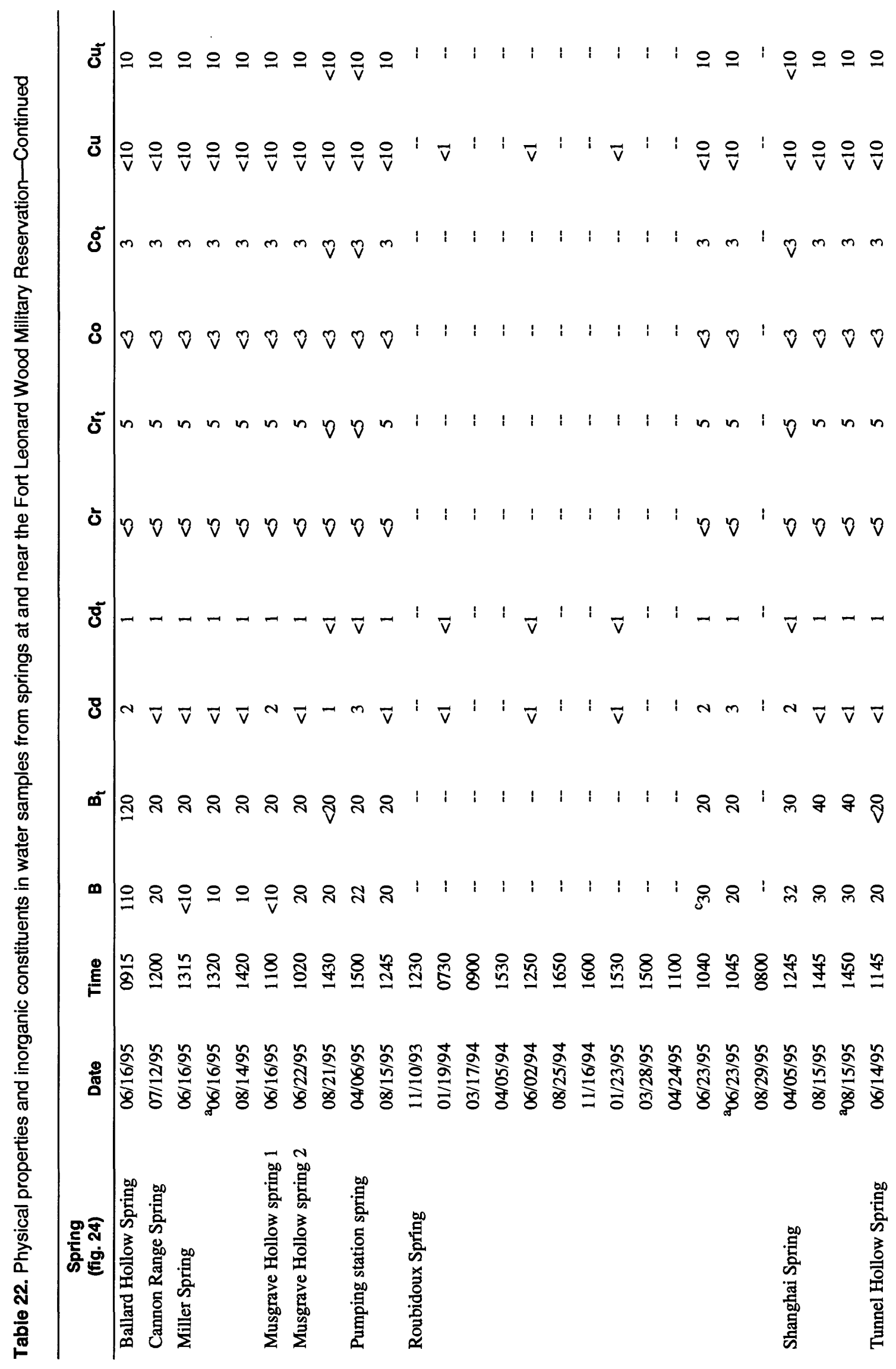




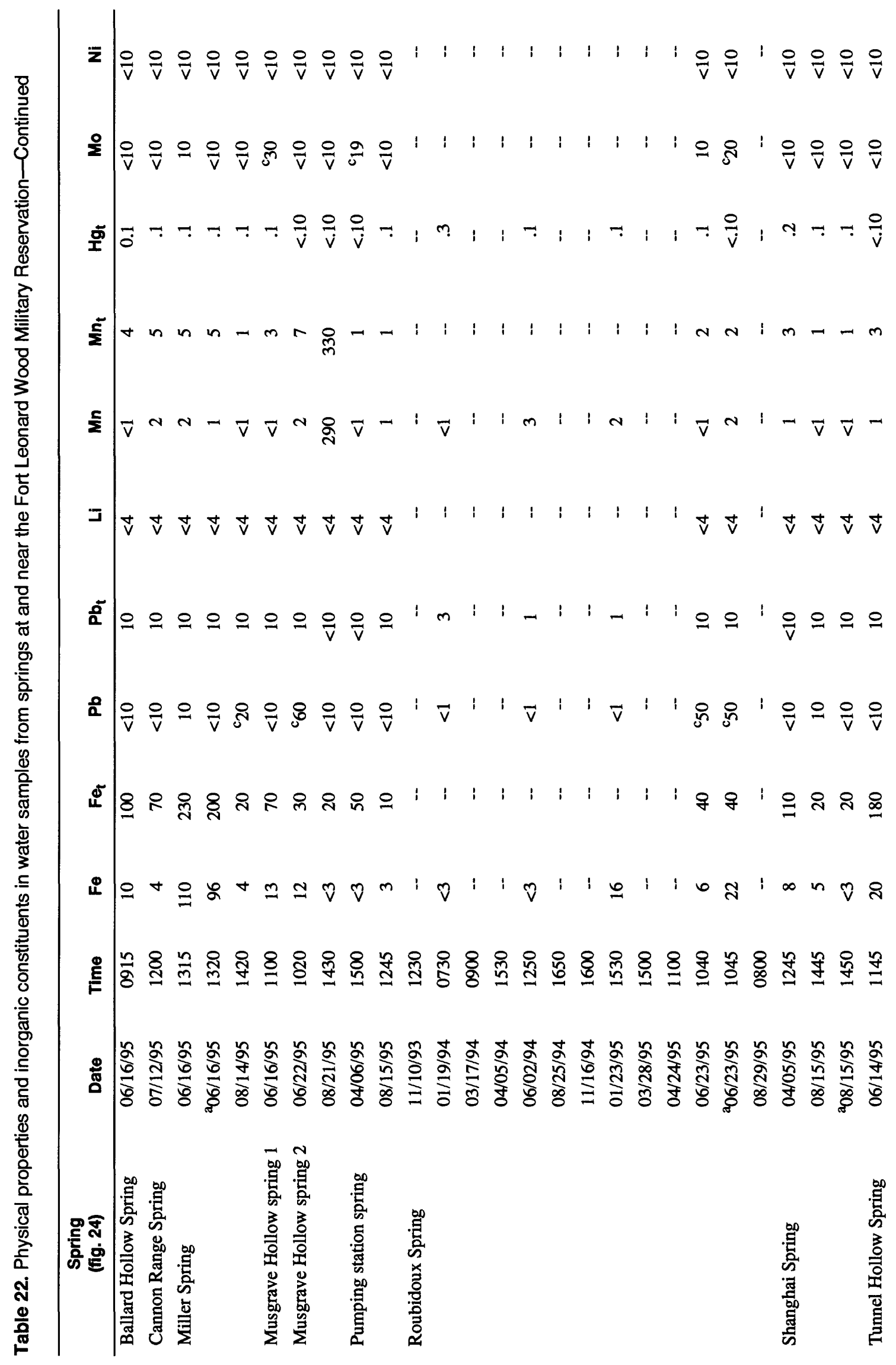




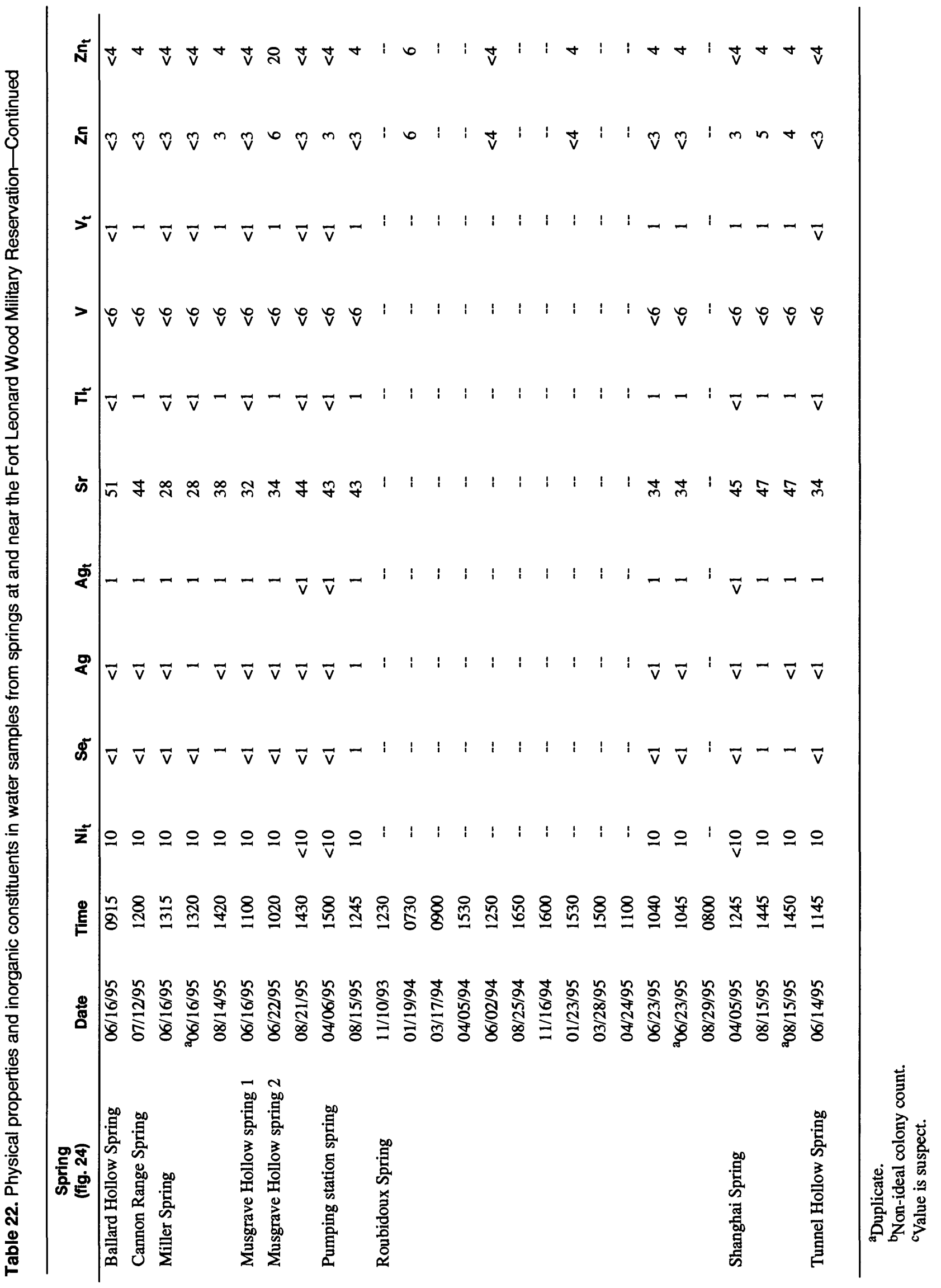




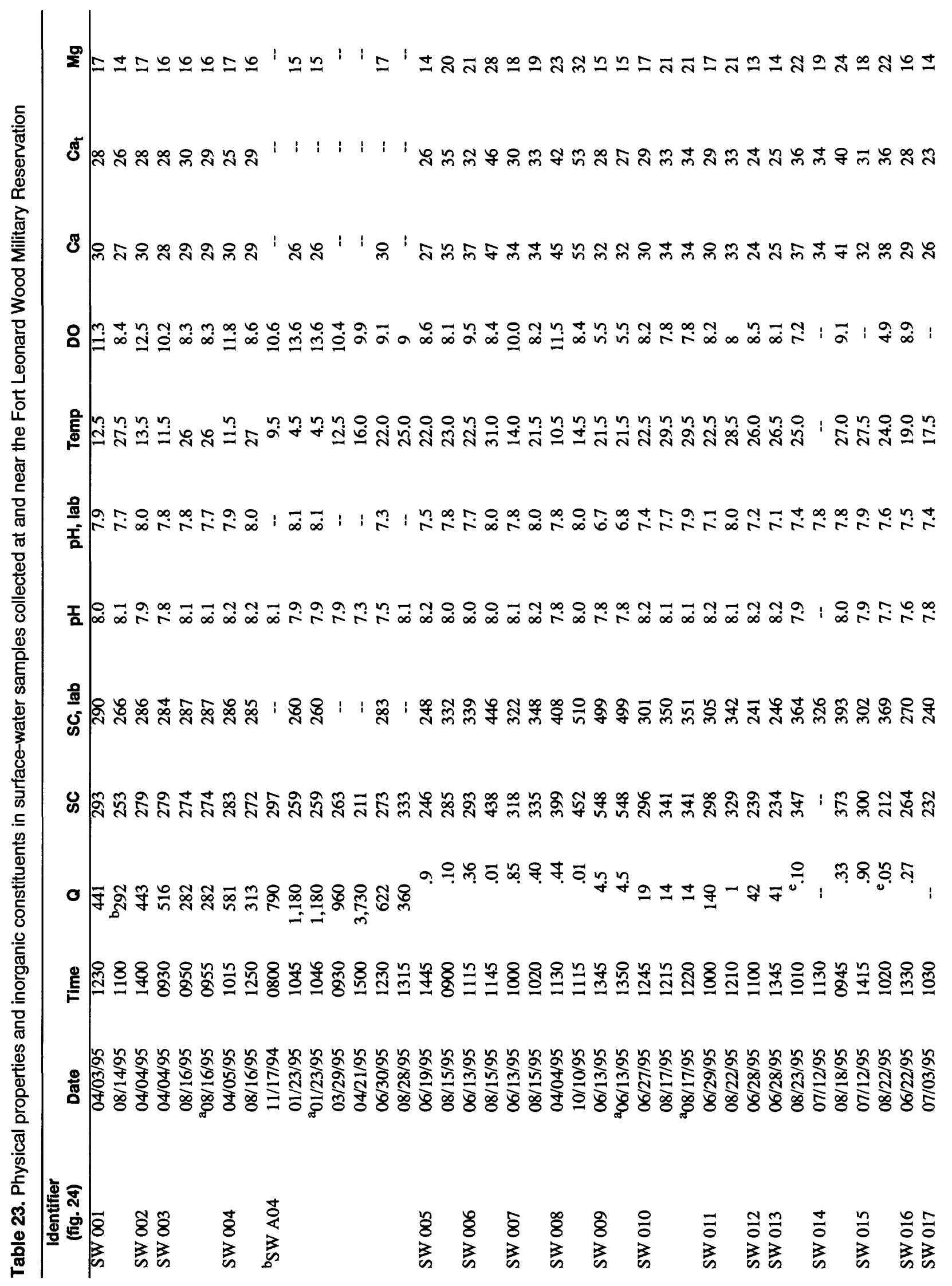




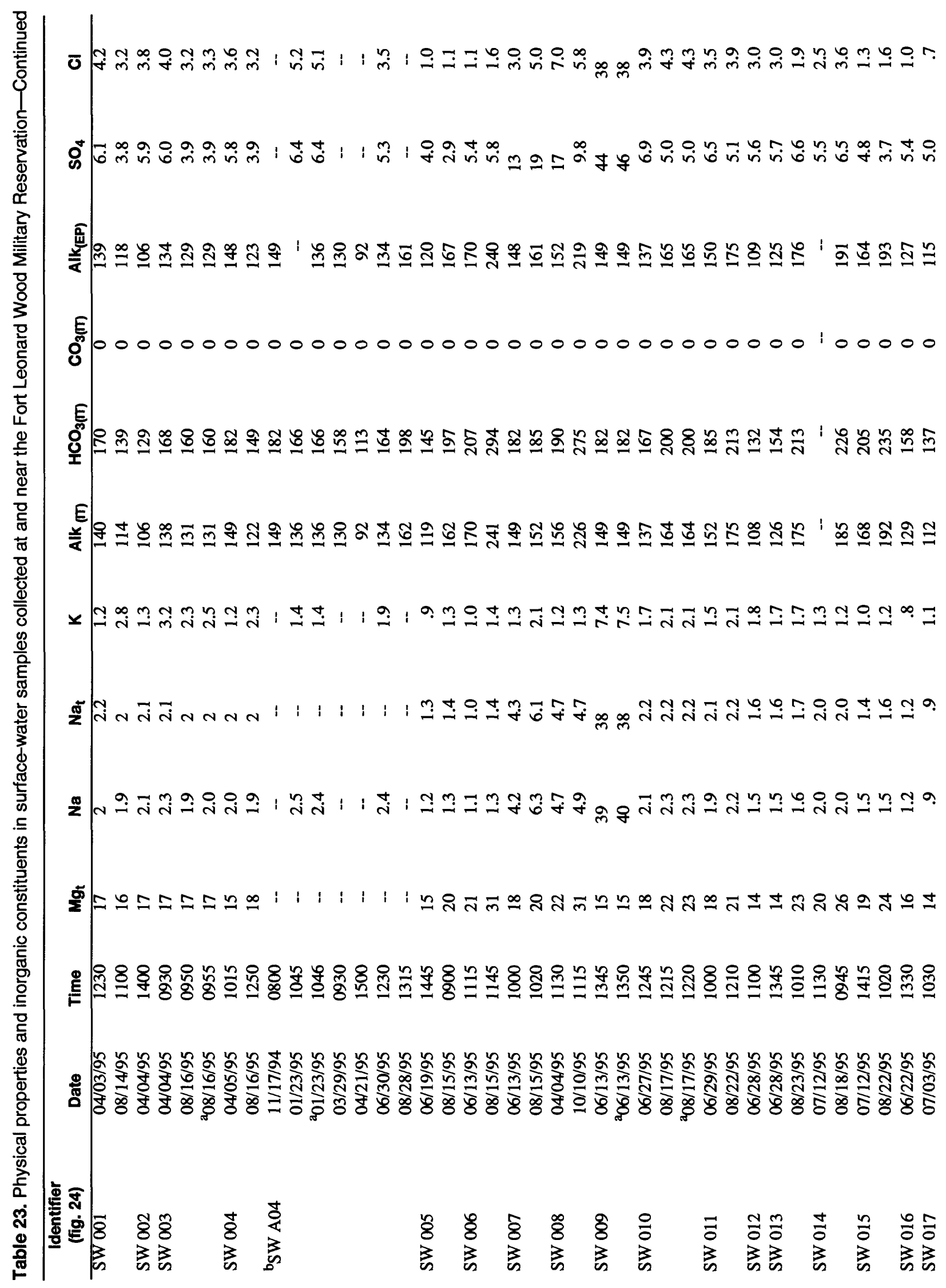




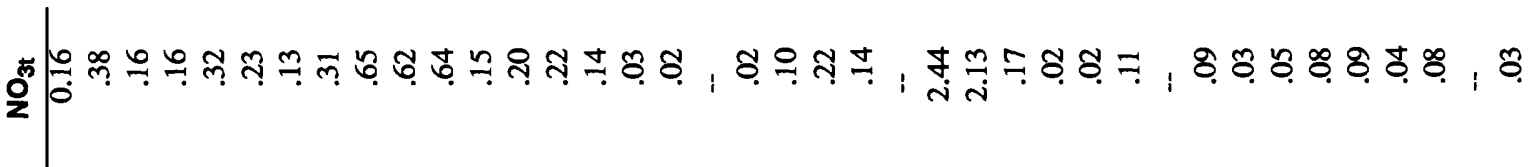

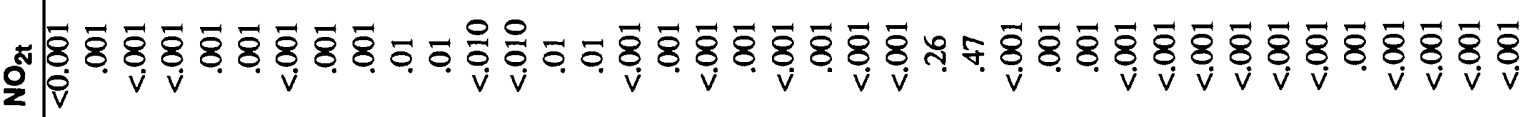

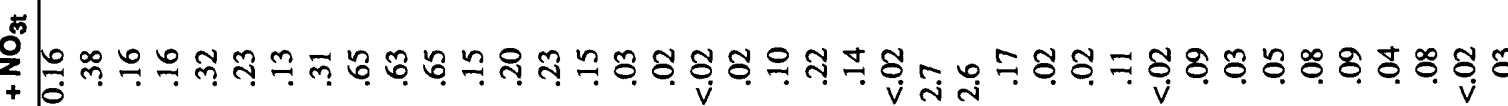
党

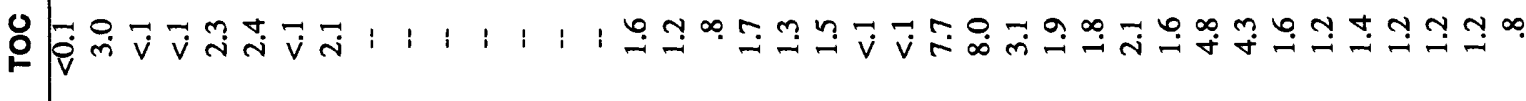

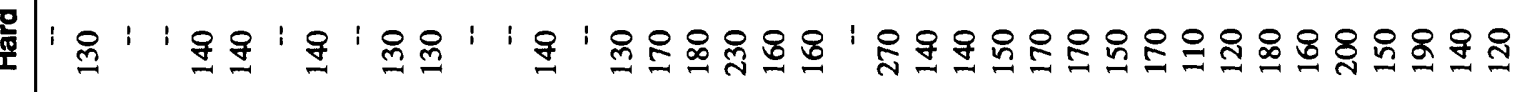

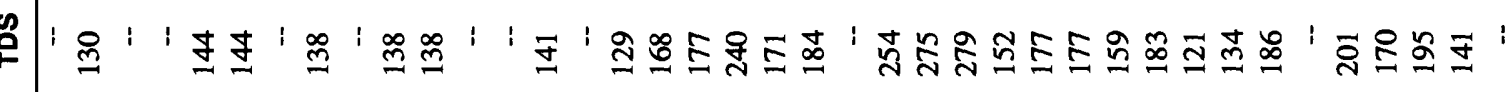

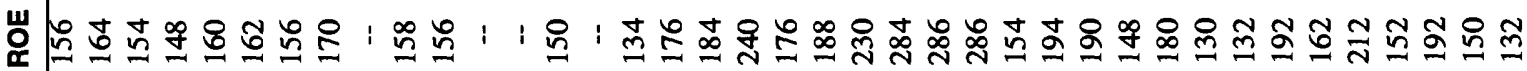
ż

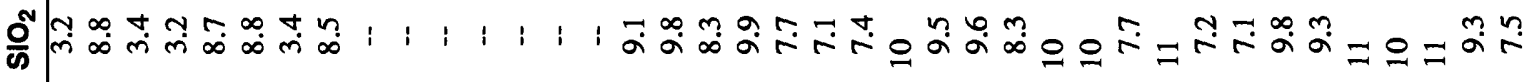

u

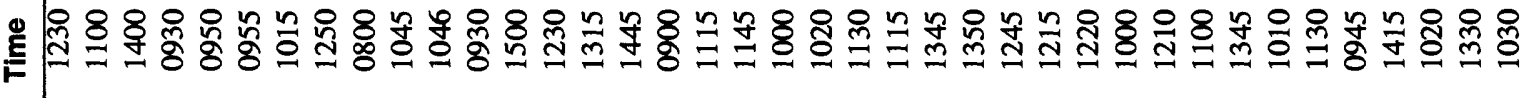

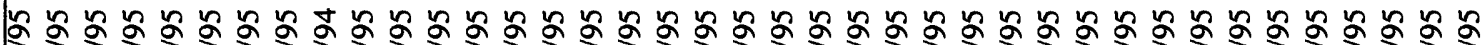

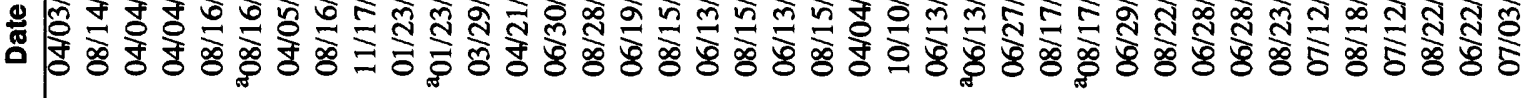




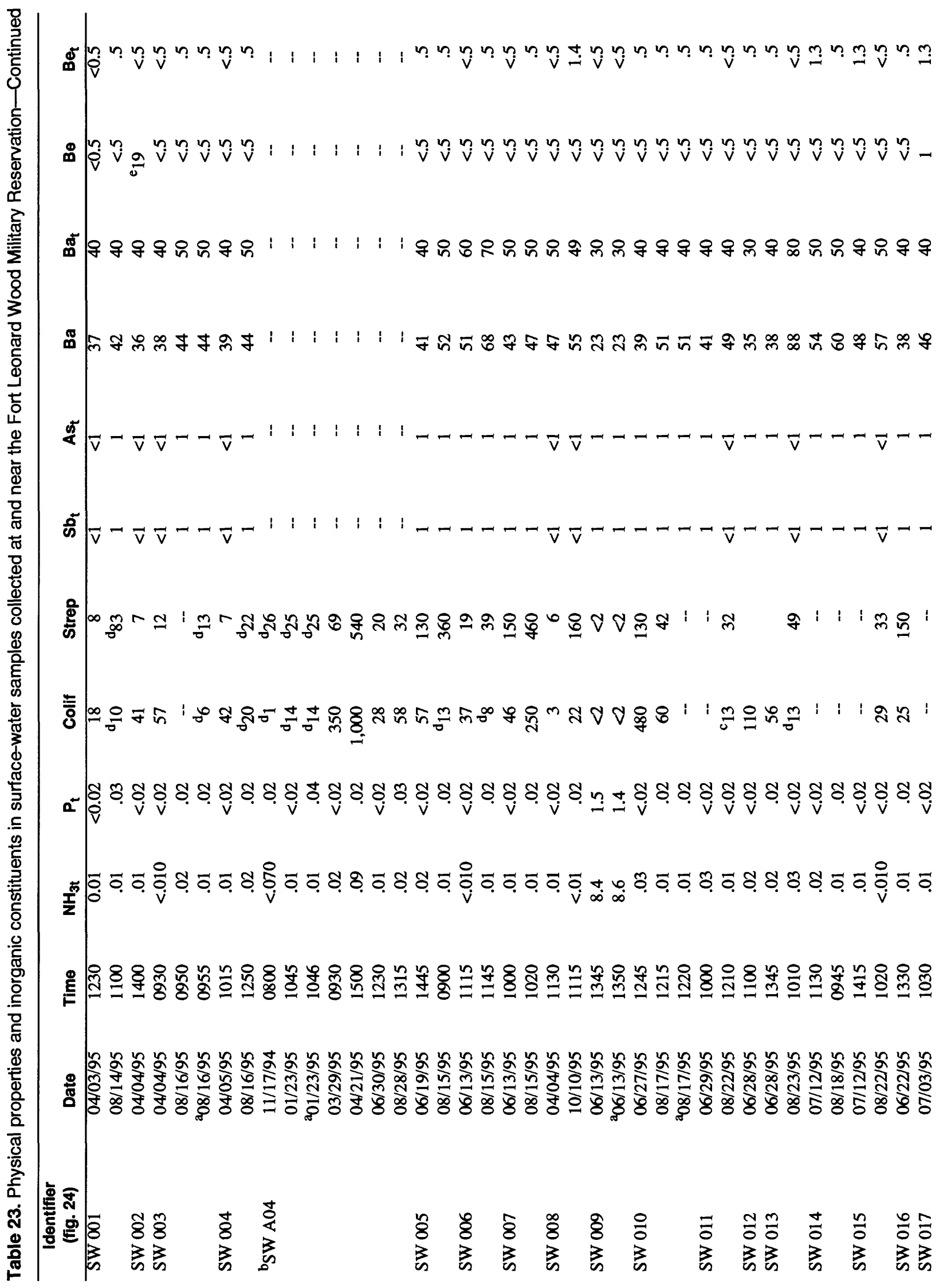




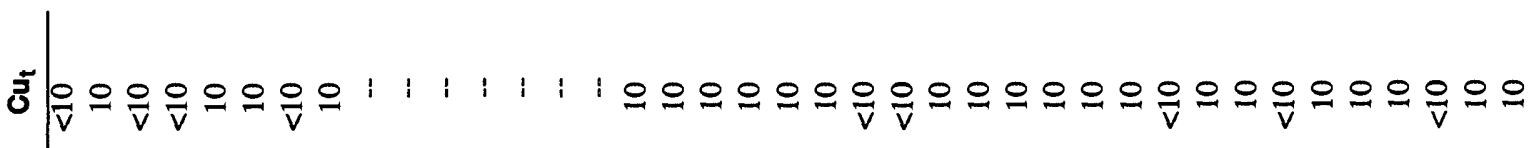

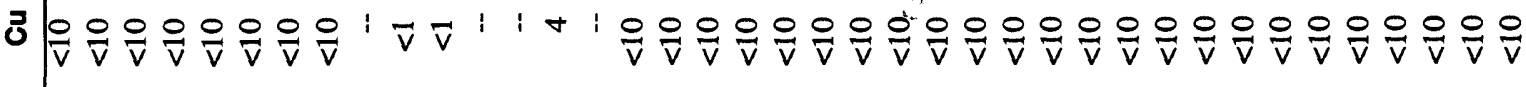

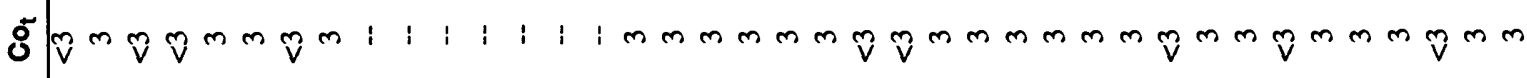

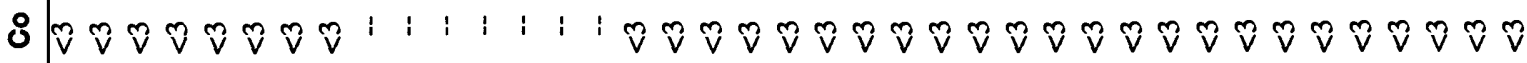

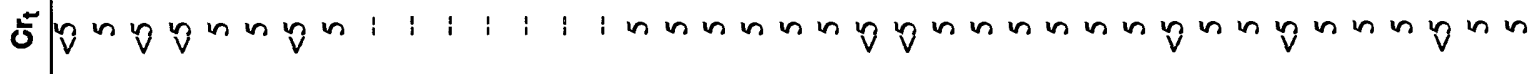

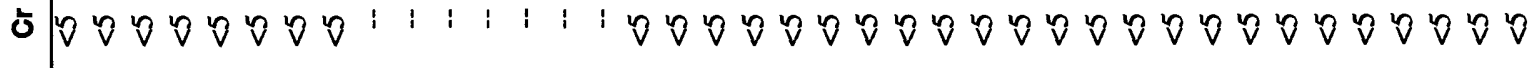

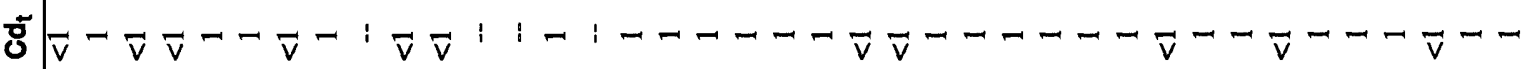
ठ $\vec{v} \vec{v} \vec{v}^{n} \vec{v} \vec{v}-\vec{v}: \vec{v} \vec{v}:: \exists:-\vec{v} \vec{v} \vec{v} \vec{v} \vec{v} \vec{v} N N \vec{v} \vec{v} \vec{v} \vec{v} \vec{v} \vec{v} \vec{v} \vec{v} \vec{v} \vec{v} \vec{v} \sim \vec{v}-\vec{v}$ "

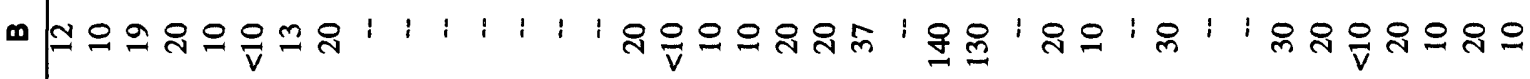

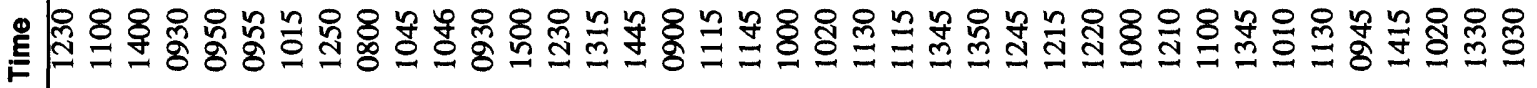

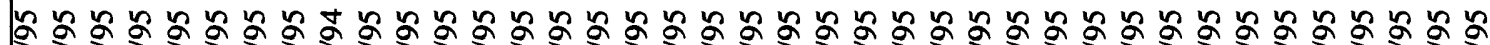

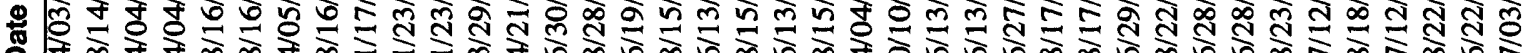

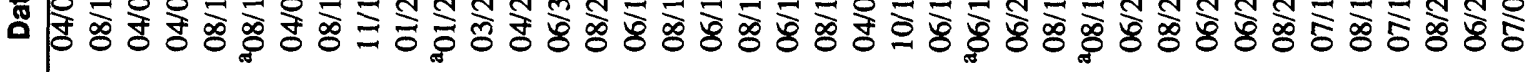




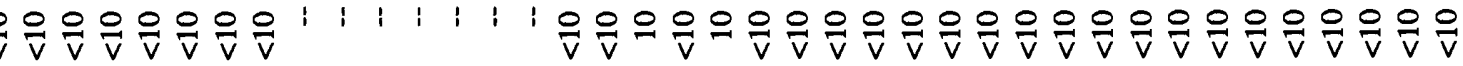

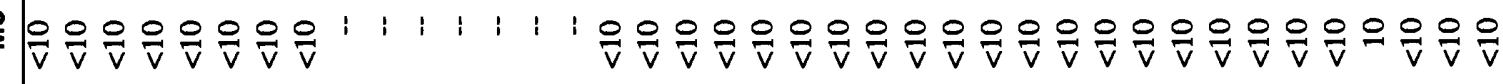

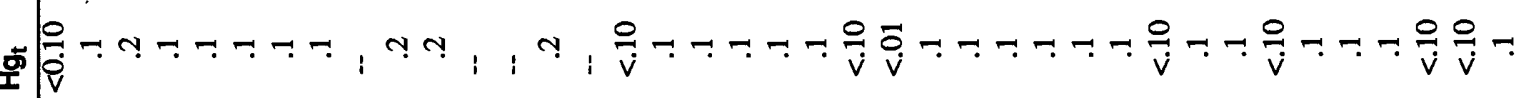

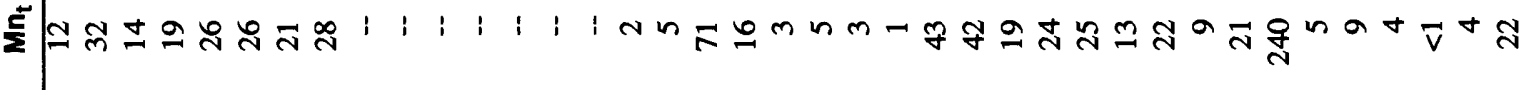

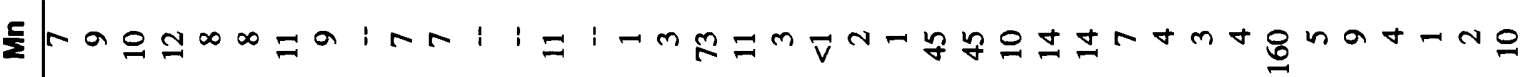

ב

홈

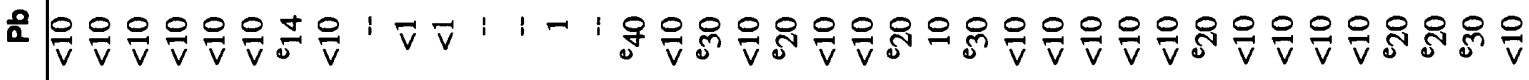

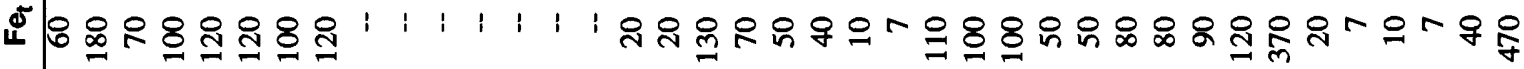

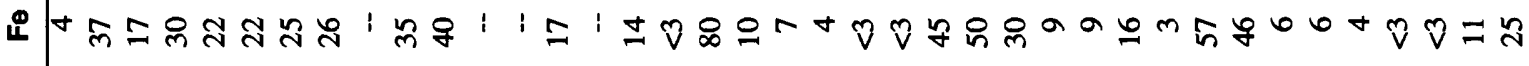

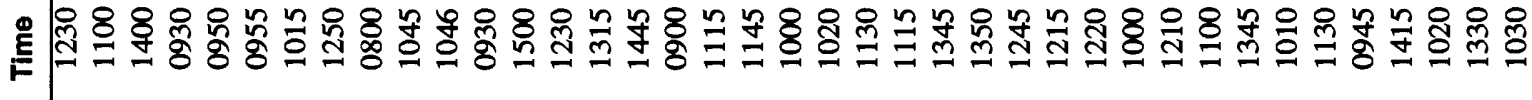

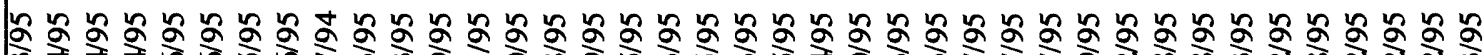

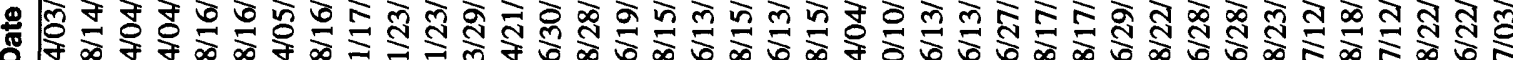

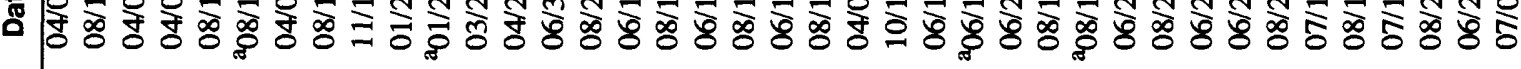

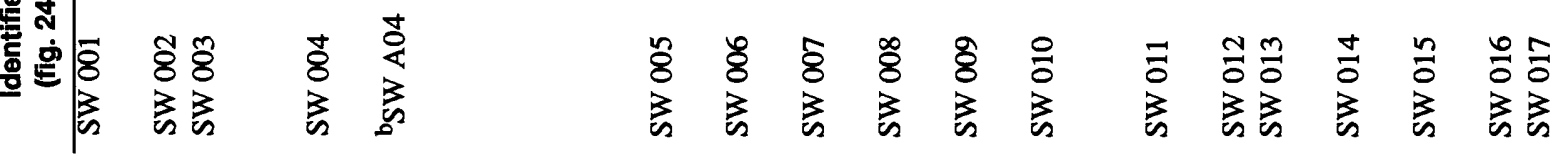




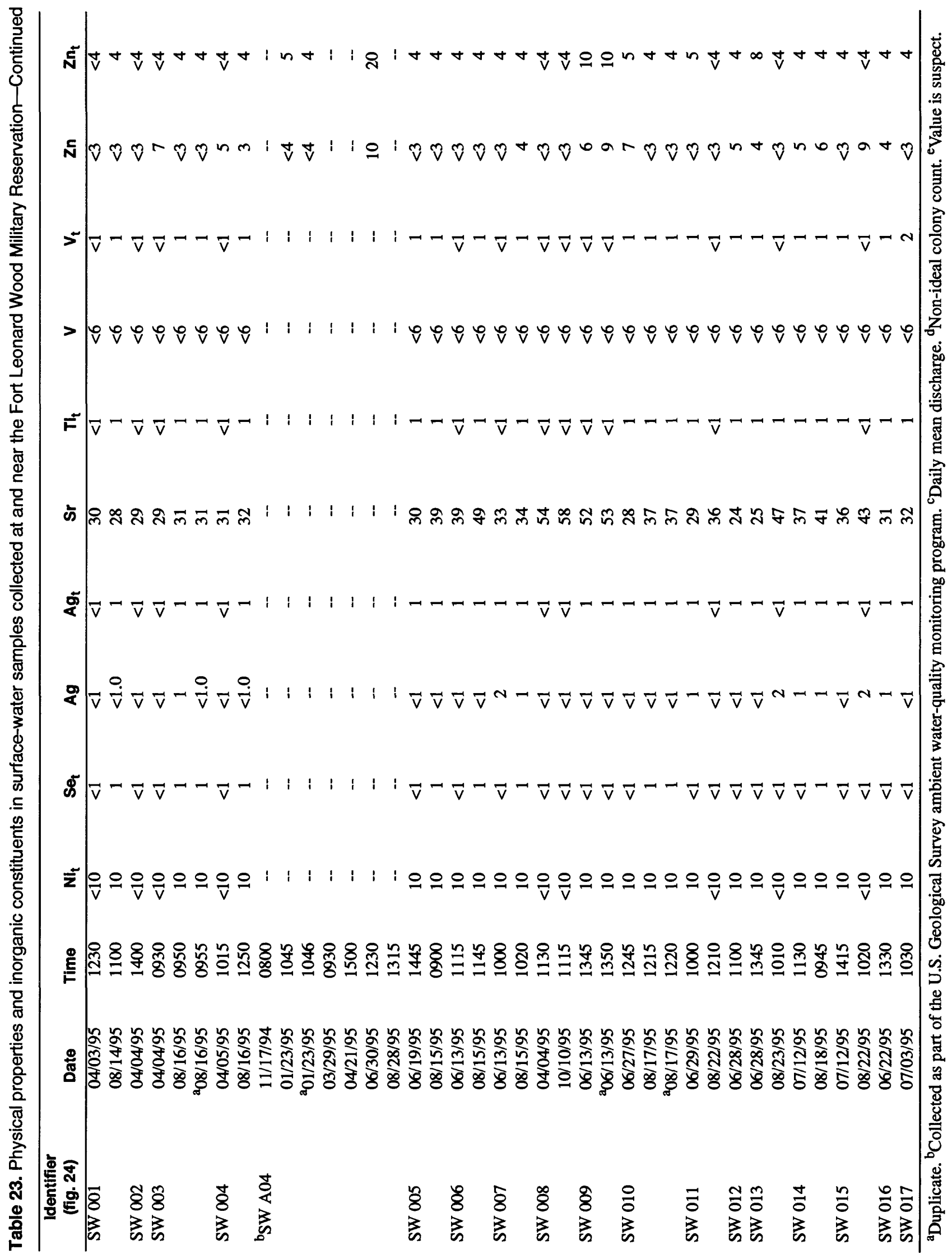




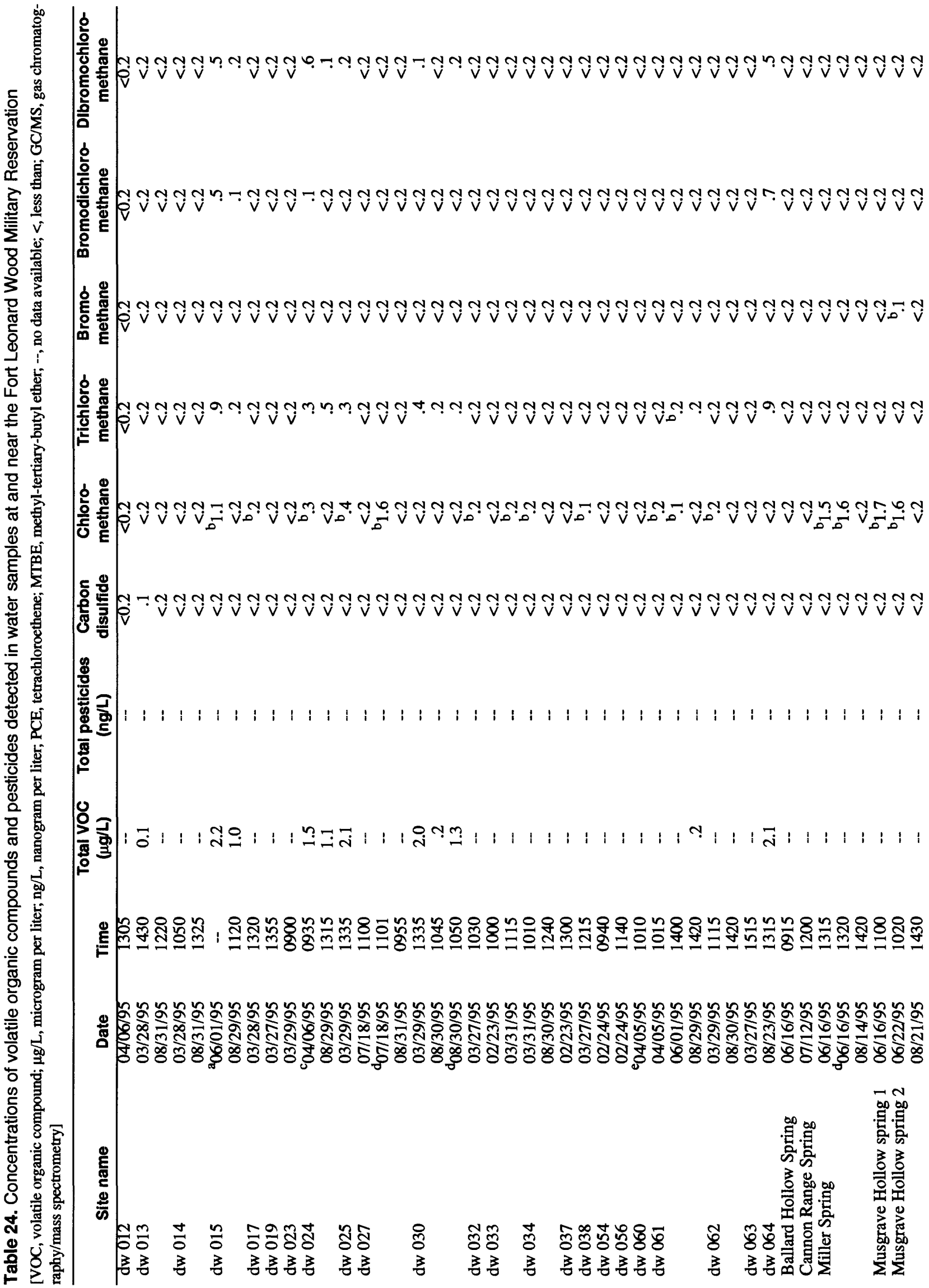




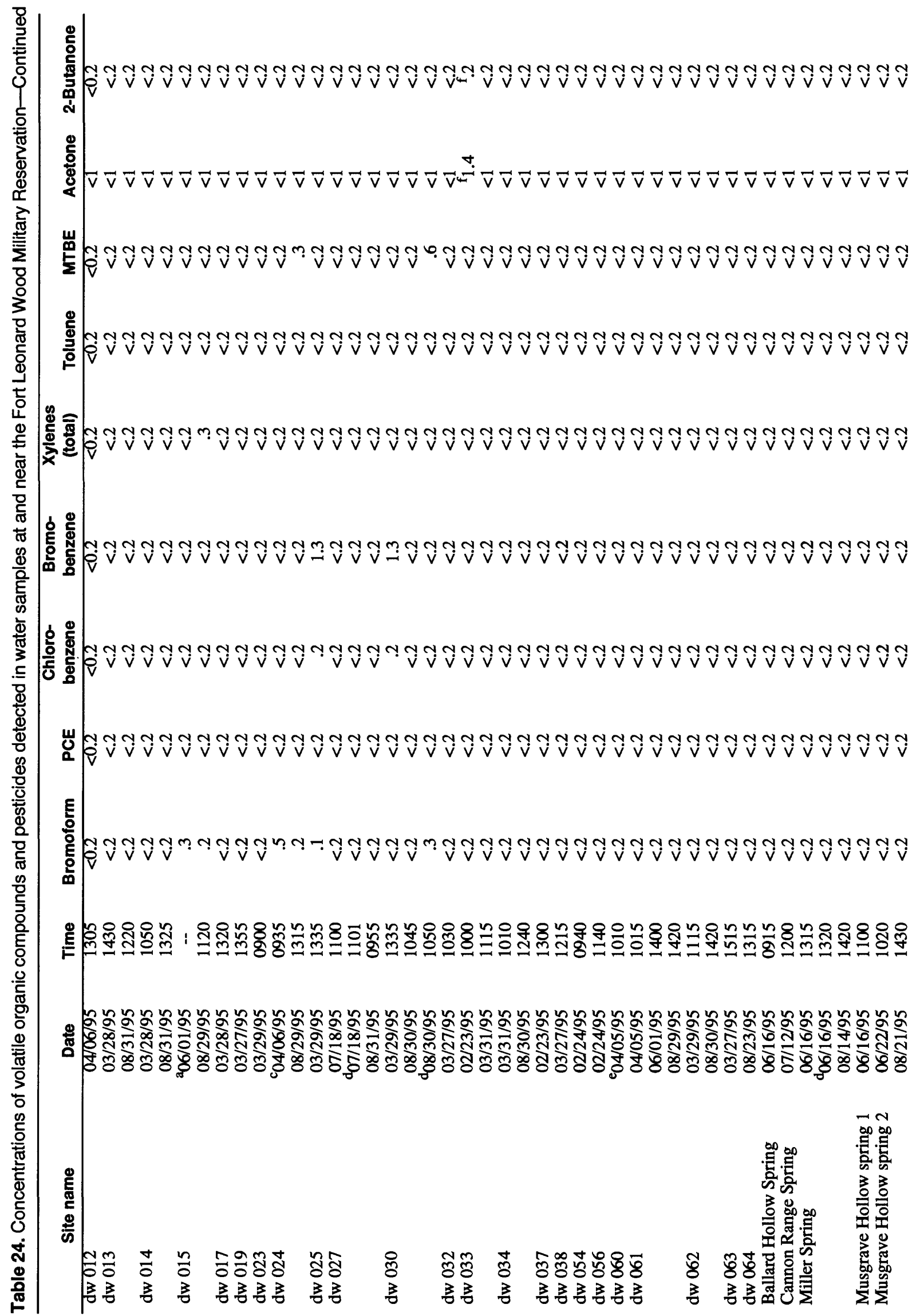




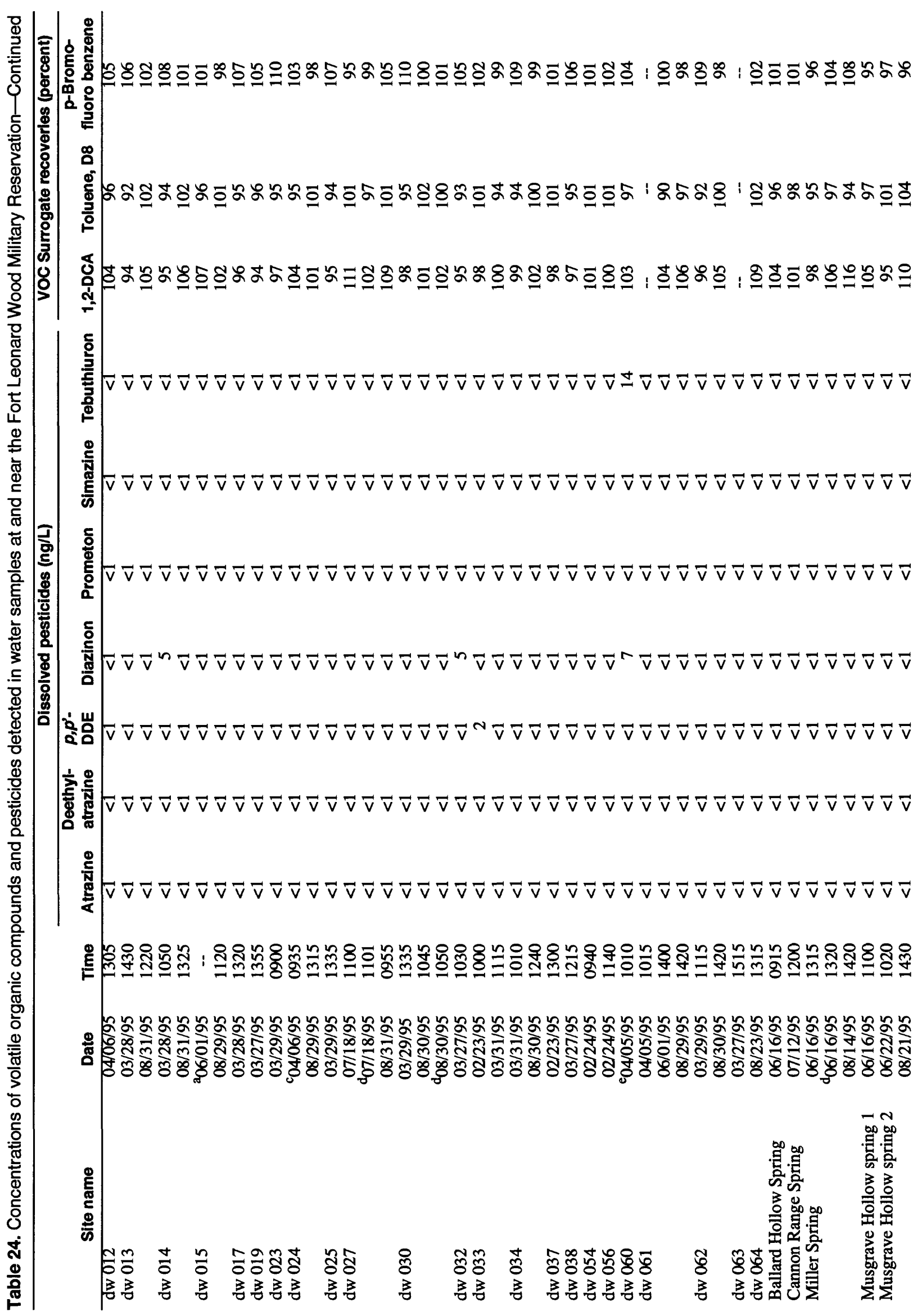




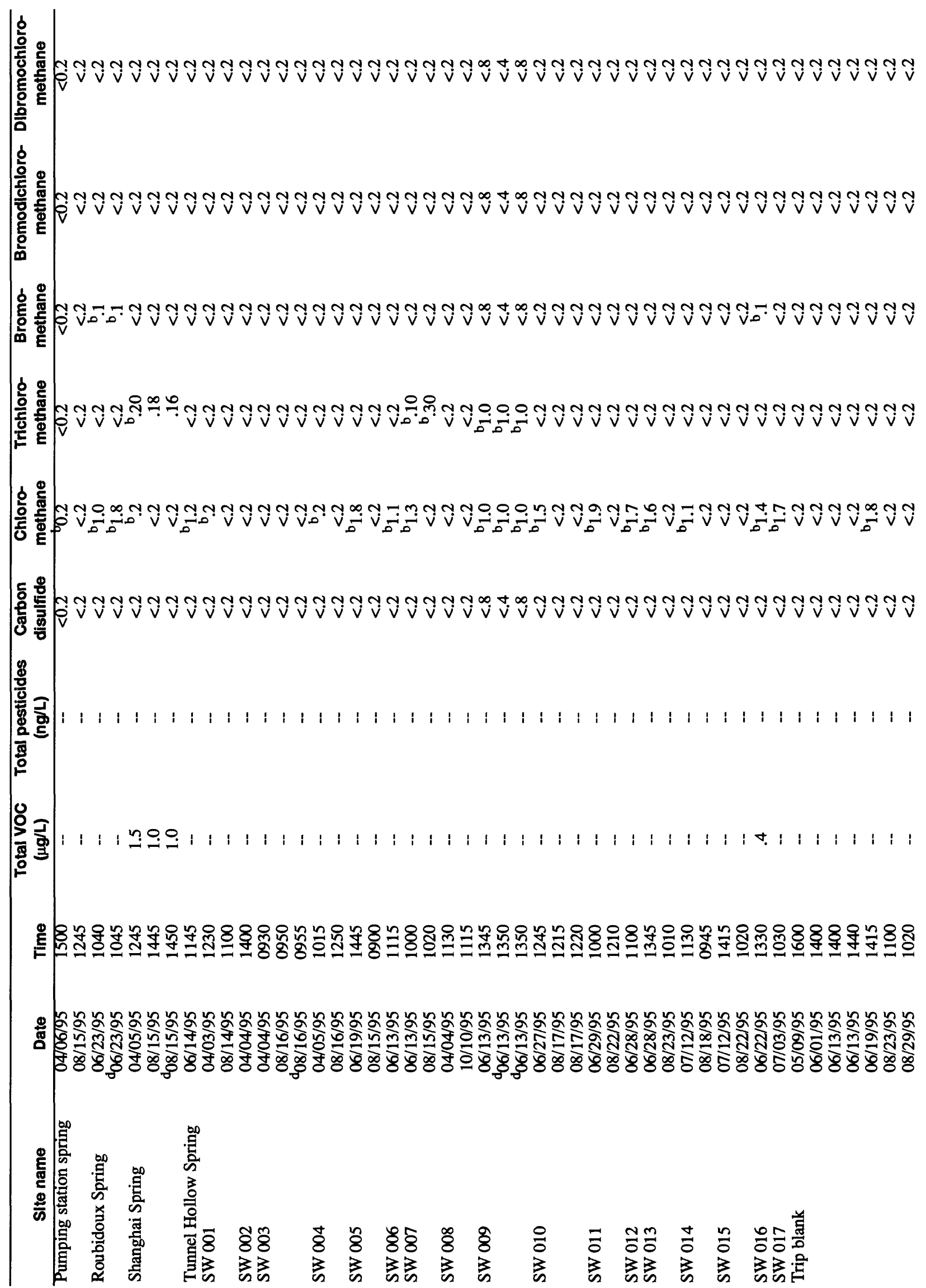


 $\vec{v} \vec{v} \vec{v} \vec{v} \vec{v} \bar{v} \vec{v} \vec{v} \vec{v} \vec{v} \vec{v} \vec{v} \vec{v} \vec{v} \vec{v} \vec{v} \vec{v} \vec{v} \vec{v} \vec{v} \vec{v} \vec{v} \vec{v} \stackrel{\infty}{\dot{v}} \stackrel{\infty}{v} \stackrel{\infty}{v} \vec{v} \vec{v} \vec{v} \vec{v} \vec{v} \vec{v} \vec{v} \vec{v} \vec{v} \vec{v} \vec{v} \vec{v} \vec{v} \vec{v} \vec{v} \vec{v} \vec{v} \vec{v} \vec{v} \vec{v} \vec{v}$

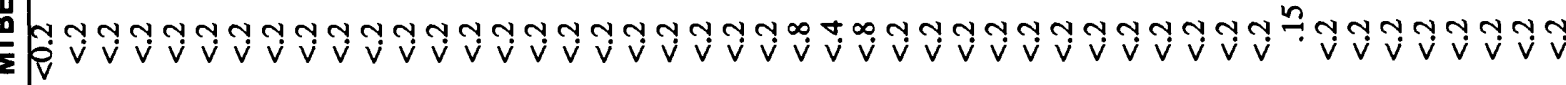

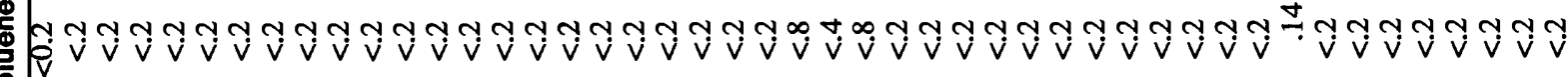

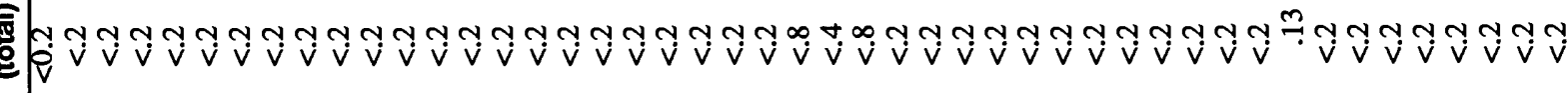

จุป



แ้ٕ

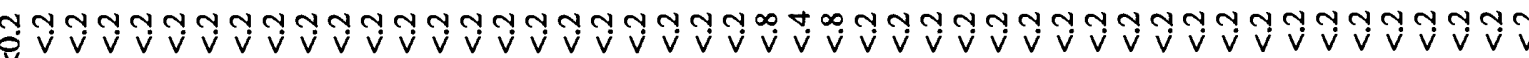

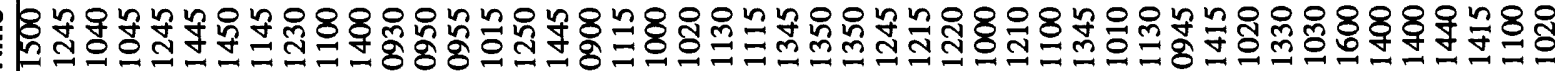

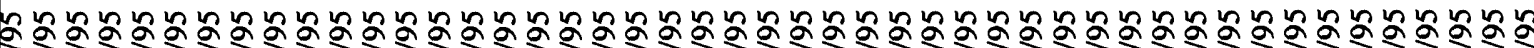
$8 n$ nलnn

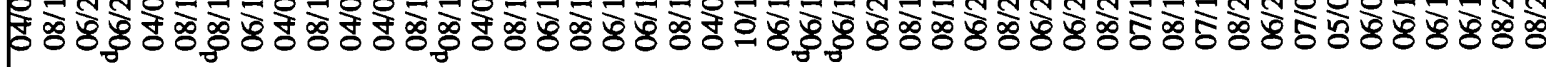

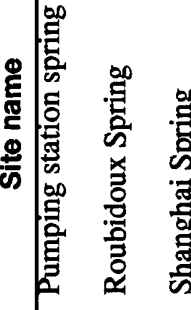

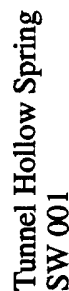

$\delta \tilde{\delta}$ $\begin{array}{ll}8 \\ 8 & 8 \\ 3 & 3\end{array}$

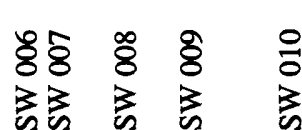




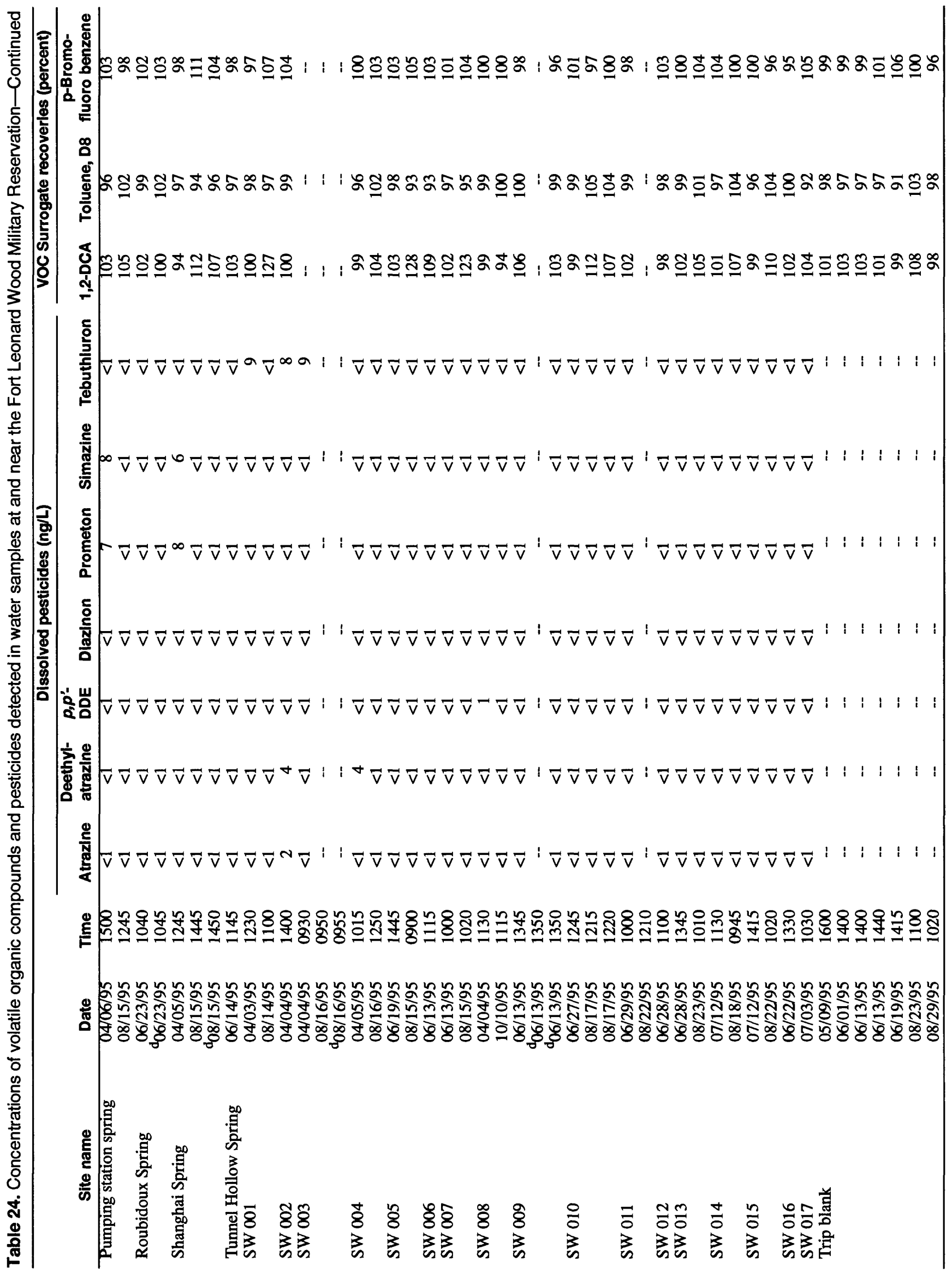




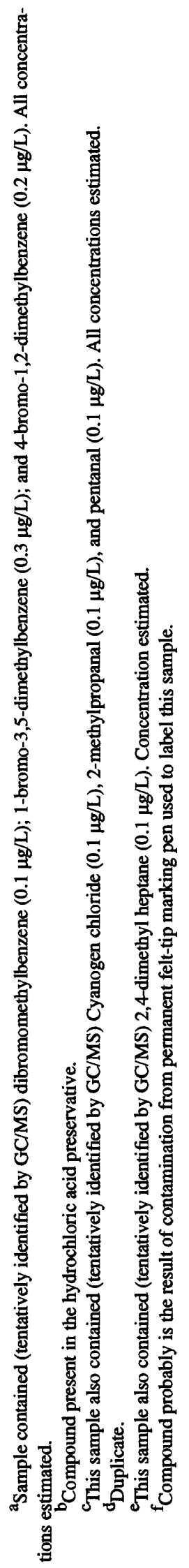

134 Geohydrologic and Water-Quallty Assessment of the Fort Leonard Wood MIlItary Reservation, MIssourI, $1994-95$ 